\title{
A God of Time and Space:
}

New Perspectives on Bob Dylan and Religion

Robert W. Kvalvaag and Geir Winje (Eds.)

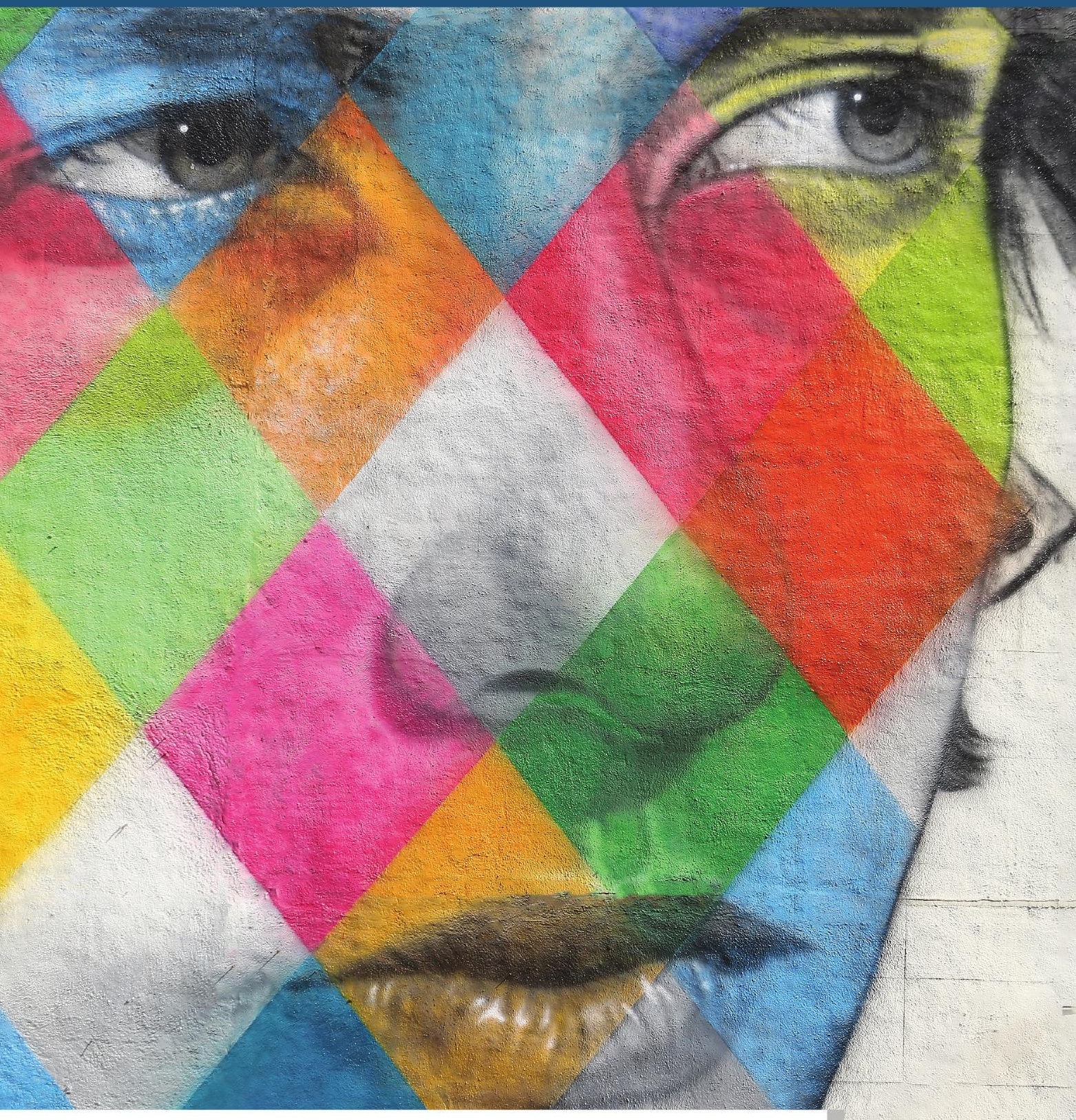


A God of Time and Space 

Robert W. Kvalvaag and Geir Winje (Eds.)

\section{A God of Time and Space}

NEW PERSPECTIVES ON BOB DYLAN AND RELIGION 
(C) 2019 Robert W. Kvalvaag, Geir Winje, Anders Thyrring Andersen, Pål Ketil Botvar, Petter Fiskum Myhr, Gisle Selnes, Erling Aadland and Reidar Aasgaard.

The album covers presented in chapter 5 are not included in the CC BY 4.0 licence. The album covers cannot be reused without permission.

Album covers are used by the courtesy of Sony Norge.

This work is protected under the provisions of the Norwegian Copyright Act (Act No. 2 of May 12, 1961, relating to Copyright in Literary, Scientific and Artistic Works) and published Open Access under the terms of a Creative Commons Attribution 4.0 International (CC BY 4.0) License (https://creativecommons.org/licenses/by/4.0/). This license allows third parties to freely share, copy and redistribute the material in any medium or format as well as adapt, remix, transform, and build upon the material for any purpose, including commercial purposes, provided the work is appropriately credited to the author(s), including a link to the license, and changes, if any, are thoroughly indicated. Attribution can be provided in any reasonable manner, however, in no way that suggests the author(s) endorse(s) the third party or the third party's use of the work.

Third parties are prohibited from applying legal terms or technological measures that restrict others from doing anything permitted under the terms of the license. Note that the license may not provide all of the permissions necessary for an intended reuse; other rights, for example publicity, privacy, or moral rights, may limit third party use of the material.

ISBN print edition: 978-82-02-66011-6

ISBN PDF: 978-82-02-61654-0

ISBN EPUB: 978-82-02-63262-5

ISBN HTML: 978-82-02-66007-9

ISBN XML: 978-82-02-66008-6

DOI: https://doi.org/10.23865/noasp.74

This is a peer-reviewed anthology.

Cover Design: Cappelen Damm AS

Cappelen Damm Akademisk/NOASP

www.noasp.no

noasp@cappelendamm.no 


\section{Contents}

Introduction: Bob Dylan and Religion: New Perspectives from

the North Country .................................................................................................... 7

Chapter 1 "Señor (Tales of Yankee Power)": A Window into Bob

Dylan's Existential and Religious World .17

Reidar Aasgaard

Chapter 2 "The Titanic sails at dawn": Bob Dylan, "Tempest", and the Apocalyptic Imagination.

Robert W. Kvalvaag

Chapter 3 Against Liberals: Multi-layered and Multi-directed Invocation in Dylan's Christian Songs ....................................... 91

Erling Aadland

Chapter 4 When the Wind is the Answer: The Use of Bob Dylan

Songs in Worship Services in Protestant Churches 119

Pål Ketil Botvar

Chapter 5 The Visual Dylan: Religious Art, Social Semiotics and

Album Covers

Geir Winje

Chapter 6 Bob Dylan's Conversions: The "Gospel Years" as

Symptom and Transition

Gisle Selnes

Chapter 7 Hard Rain: The End of Times and Christian Modernism in the Work of Bob Dylan 183

Anders Thyrring Andersen

Chapter 8 Bob Dylan's Ten Commandments - a Method for

Personal Transformation

Petter Fiskum Myhr 



\title{
INTRODUCTION
}

\section{Bob Dylan and Religion: New Perspectives from the North Country}

\author{
Robert W. Kvalvaag
}

OsloMet - storbyuniversitetet

Oslo Metropolitan University

\section{Geir Winje}

Universitetet i Sørøst-Norge

University of South-Eastern Norway

Dylan: "If I had to do it all over again, I'd be a schoolteacher - probably teach Roman history or theology."

- Love (2015, p. 52)

The present volume is a collection of essays aiming to shed new light on different aspects of the role of religion in Bob Dylan's artistic output. The eight authors are all from Scandinavia, seven from Norway and one from Denmark. Norwegian Dylan-scholars will always remember when Dylan, at a concert in Oslo in 1998, compared Norway to where he grew up in Minnesota: "Well, I feel quite at home here, actually. I was born and raised in Minnesota, where the Vikings landed long before Columbus did" (Botvar, 2011, p. 166). In Chronicles Dylan remembers when his parents brought him to a political rally in Duluth's Leif Erickson Park: "Leif Erickson was a Viking who was supposed to have come to this part of the country [Minnesota] way before the Pilgrims had ever landed in Plymouth Rock" (Dylan, 2004, p. 230).

Few would dispute the fact that religion or religious traditions and the use of religious imagery have always played an important role in Dylan's artistry. However, the term "religion" is ambiguous and not easy to define. This 
ambiguity comes across in interviews with Dylan, where he uses the word in different ways, often with negative connotations. A critical attitude to the term and the whole concept of religion is also traceable in Dylan's lyrics. The word appears in three of his own compositions. Two of these occurrences are from the mid-sixties, and one is from his gospel period in the late seventies.

The word religion first appears in "Desolation Row" (1965), a song in which Dylan imagines modern Western culture as a ship of fools about to go down. He presents the listener with a variety of figures from Western literature, folklore and history. Among the many characters in this song is Shakespeare's Ophelia, and she is as tragic a figure in Dylan's lyrics as she is in Hamlet. She is looking for a sign of deliverance and fixes her hope upon the sign that in Genesis (9:13-17) indicates both the end of the flood sent to purge humankind and the beginning of a new covenant between God and humanity.

What is the matter with Dylan's Ophelia?

Her profession's her religion

Her sin is her lifelessness

And though her eyes are fixed upon

Noah's great rainbow

She spends her time peeking

Into Desolation Row

For Ophelia religion is a profession, but not one that provides her with the answers she seeks. Her problem, or "sin", is "her lifelessness", which in Dylan's text is paralleled by "her religion" in the preceding line. In other words, religion seems to be synonymous with death, and hinders Ophelia's ability to see the symbol of hope, the great rainbow. Here "religion" represents the opposite of deliverance and redemption; it will not save Ophelia from drowning. Using words from "It's all right ma (I'm only bleeding)" one can say that Ophelia's religion is not about busy being born, but rather busy dying.

The second appearance of the word religion in Dylan's song work is in "Can You Please Crawl out of Your Window" (1965), released as a single late in 1965. In Louis A. Renza's recent interpretation, this "put-down" song has Dylan imagining someone quite literally listening to his song: 
While his genocide fools and his friends rearrange

Their religion of the little ten [tin?] women

That backs up their views but your face is so bruised

Come out the dark is beginning

According to Renza's autobiographical reading it is Dylan who "disdains 'his genocide fools', those uncritical and non-anxious listeners who would adopt his hip vision of life and exclude anyone else who follows a different one". There is a close connection between "religion" and "the little ten women" (bobdylan.com has "tin"); "a trope for any number of superficial or small-minded admirers” (Renza, 2017, p. 39-40).

In other words, religion belongs to the shallow world of those who listen to his songs with no real understanding of what they are about. The line "Come out the dark is beginning" might be a reference to some kind of apocalyptic scenario. In any case, religion will not be of any help if you are trying to escape from what is fake in order to face the real world. Three days before recording "Can You Please Crawl out Your Window", on November 27 1965, Dylan did an interview with Joseph Haas (JH):

JH: What about religion or philosophy?

BD: I just don't have any religion or philosophy. I can't say much about any of them [...]. Philosophy can't give me anything that I don't already have. The biggest thing of all, that encompasses it all, is kept back in this country. It's an old Chinese philosophy and religion, it really was one ... There is a book called the I-Ching. I'm not trying to push it, I don't want to talk about it, but it is the only thing that is amazingly true, period, not just for me. (Cott, 2017, p. 62-63)

Dylan flatly denies having any religion or philosophy. Then he apparently changes his mind and answers in the affirmative: There is a philosophy and a religion that is amazingly true, not just for him, but probably for everyone. It is to be found in the ancient Chinese divination text, the I-Ching, also known as the Book of Changes. The I Ching introduces the doctrine of the balance of opposing but complementary forces of Yin and Yang. It became popular in the sixties' counterculture, and in 1966, Dylan's close friend Allen Ginsberg wrote a widely distributed poem titled "Consulting I-Ching Smoking Pot Listening to the Fugs Sing Blake". 
The third time Dylan uses the word religion is in the song "Slow Train" (1978). Here Dylan describes what he believes is wrong with the world, including himself, the people around him, the OPEC cartel, inflated egos of humankind, phony leaders and even his loved ones. Dylan does not spare religious hypocrites either:

But the enemy I see

Wears a cloak of decency

All nonbelievers and men stealers talkin' in the name of religion

And there's a slow, slow train comin' up around the bend

Someone uses religious language to make something profane sound like it is sacred. Dylan places his "Slow Train" narrative in the context of man's relationship with God. He warns that the day of reckoning is approaching: "There's a slow, slow train comin' up around the bend". The train could be the second coming of Jesus, or a harbinger of the apocalypse, as predicted in the Book of Revelation. However, the slow train does not represent religion; on the contrary, religion is associated with people who do not belong on the train: "nonbelievers and men stealers talkin' in the name of religion".

In December 1979 Dylan did an interview (a conversation with Bruce Heiman from KMEX radio in Tucson) in which he was very outspoken as far as the subject of religion is concerned. Dylan explained what had recently happened to him in the following terms:

Christ is no religion. We're not talking about religion ... Jesus Christ is the Way, the Truth, and the Life [...]. Religion is repressive to a degree. Religion is another form of bondage which man invents to get himself to God [...]. Christ didn't preach religion [...]. He talked about life, not necessarily religion [...]. (Cott 2017, p. 289-290)

The years from 1979 to 1981 are characterized by some critics as "Dylan's religious period" (e.g. Trager, 2004, p. 186). By his own account, Dylan had not become religious or a follower of religion; in fact he rejected the whole idea: "Religion is a dirty word" (Williams, 1985, p. 22). Instead he described what had happened to him as a born-again experience, an encounter with Jesus. 
In an interview from May 2007, Jann S. Wenner (JW) from Rolling Stone Magazine asked Dylan (BD) several questions dealing with the subject of religion:

JW: At one point, you took on Christianity in a very serious way, and then Judaism. Where are you now with all that?

BD: $\quad$ Religion is something that is mostly outward appearance. Faith is a different thing. How many religions are there in the world? Quite a few, actually.

JW: What is your faith these days?

BD: $\quad$ Faith doesn't have a name. It doesn't have a category. It's oblique. So it's unspeakable. We degrade faith by talking about religion. (Cott, 2017, p. 488)

Here Dylan makes an important distinction between faith on the one hand and religion on the other. Like many others living in a post-secular world who believe in a God or some kind of higher power, Dylan clearly does not identify with "religion". On the contrary, he claims that religion is mainly concerned with appearances. He instead introduces the concept of faith, as something radically different from religion. While religion has a name (e.g. Christianity or Judaism), faith does not. It does not belong to a fixed category; it is oblique and unspeakable.

This is similar to what Dylan said to Jon Pareles in 1997 after the release of Time Out of Mind. Dylan told Pareles that he does not subscribe to any organized religion, but the source of his faith is old, traditional songs:

Those old songs are my lexicon and prayer book. All my beliefs come out of those old songs, literally, anything from 'Let Me Rest on That Peaceful Mountain' to 'Keep on the Sunny Side'. You can find all my philosophy in those old songs. I believe in a God of time and space, but if people ask me about that, my impulse is to point them back toward those songs. I believe in Hank Williams singing 'I Saw the Light'. I've seen the light too. (Cott, 2017, p. 419-420, our italics)

In the first chapter of A God of Time and Space, Reidar Aasgaard provides a detailed analysis of the song "Señor (Tales of Yankee Power)". 
He shows that "Señor" is a polyphonic text, which - like many other Dylan songs - evades one single interpretation. It can be heard as a historical song, a story about migration and ethnic tension, a description of love lost, of human uprooting, of existential crisis, or even as an autobiographical account of Dylan himself. Aasgaard argues, however, that religion, and Christianity in particular, plays a central and integral part in the various interpretations. The song reflects Dylan's artistic and personal situation at the time, but also fits well in a long trajectory of Dylan songs, from the 1960 s to the present, that deal with fundamental human themes related to history, society, social relations, religion, and life in general.

At the core of Robert W. Kvalvaag's long analysis of the song "Tempest" is an attempt to discover how the song is structured, the relationship between text and music, the role of Dylan's voice, and the influence of the Titanic-movie upon Dylan's nearly quarter-hour epic ballad. The religious aspect manifests itself through the biblical material, and especially in the apocalyptic scenery, which is very vividly present in the song. In an interview, Dylan said Tempest is not the album he wanted to make; he wanted to make something more religious. Kvalvaag argues that Dylan in a subtle way achieved this goal with the "Tempest" song.

Erling Aadland maintains that Dylan's embrace of evangelical Christianity to a large extent is prefigured in much of his earlier work. Although his highly valued criticism of modern life and contemporary society in his earlier songs is taken further and extended in his gospel songs, this extension and deepening of thought has not received much appraisal. Indeed, the reverse seems to be the case. Many critics sidestep Dylan's Christian songs. Instead, they are "explained" by all sorts of evasions of the main issue: Dylan's songs have been imbued with Christianity ever since the early 1980 s.

In Pål Ketil Botvar's chapter, the use of Bob Dylan's music in church services is analysed. Special attention is given to cases where Dylan's music and lyrics are integrated into the liturgy of the mass. The Nordic Lutheran churches offer good examples of how Dylan's work is used as liturgy. Songs from Dylan's gospel period, as well as other Dylan songs, are used as part of the so-called Dylan mass. Botvar's chapter 
provides new insight into the internal discourse within the church about the use of Dylan's music. Arguments forwarded by those opposing such use and by those who embrace it are analysed on the basis of a sociological model about the relationship between religion and popular culture.

Geir Winje's essay is an attempt to study Bob Dylan's contribution to global culture from another and neglected angle, namely with the album cover art as a starting point. The cover images are not only seen as illustrations supporting verbal texts, but rather, verbal texts and images are treated as equivalent languages or modes of expression. In accordance with social semiotic theory, the album covers are read as meaningful texts on their own. In addition, portraits on the album covers are compared to portraits of Christ and saints in early Christian art. The main reason for this approach is to explore how religious, premodern language (including images) continues in our time, not because human beings today are religious, but because religious structure categories, symbols and signs still work.

Gisle Selnes analyzes Dylan's three evangelical albums as the manifestation of Dylan's proverbial poetics of transformation. Contrary to the common approach to Dylan's religiosity, Selnes underscores the exemplarity of the three albums' adherence to the "general rule" of successive investigations of different genres in the great American song tradition, which Dylan, as the Swedish Academy put it in 2016, enriches with "new poetic expressions". Thus, even more than a heartfelt religious experience, Dylan's conversion bespeaks an artistic urge to probe into a previously unexplored vein in American gospel music. Selnes argues that what characterizes Dylan's evangelical albums is their stark insistence on the "real presence" of Christ's transfigured body, before and after which Dylan maintains a more transcendental, almost pantheistic religious stance. In Selnes' reading, the very last song on Dylan's final gospel album, "Every Grain of Sand," represents a return to the more downplayed, "un-charismatic" or immanent vein of Dylan's religiosity.

Anders Thyrring Andersen sees Dylan as a Christian modernist. He stresses the importance of viewing Dylan's work as a whole, instead of 
dividing it into many phases. Andersen thus emphasizes the unity of Dylan's artistic output, and one of the constants he discovers is Dylan's critique of secular modernity. This criticism comes, on the one hand, with images of flooding waters and judgment day, and on the other hand it is paralleled by the notion of paradise, expressed through images of mountains. Further, Andersen argues, the way Dylan approaches the listener, using an indirect, dialogical and dialectical method, is reminiscent of T. S. Eliot and Søren Kierkegaard. (This chapter has not been peer reviewed.)

The volume closes with Petter Myhr's personal reflections upon Dylan's “ten commandments”. After studying Bob Dylan's life and art for many decades, Myhr has found ten rules - ten commandments - that he finds crucial to Bob Dylan's extreme ability to transform himself over the course of his long carrier. Those commandments are not only ten rules for a creative life; they are also a great roadmap for a flexible religious life and an antidote to all sorts of fundamentalism. Myhr argues that we not only need art to disrupt religion; we also need art to disrupt science and politics as well as our everyday lives - not to mention art. Obviously, we need art to disrupt art, and to Myhr, this seems to be Bob Dylan's main project throughout his long career. (This chapter has not been peer reviewed.)

In a 1997 interview with David Gates from Newsweek, Dylan used the words "religious", "religiosity" and "religion" in a positive way. $\mathrm{He}$ explained the source of his religiosity and stated "that's my religion":

Here's the thing with me and the religious thing. This is the flat-out truth: I find the religiosity and philosophy in the music. I don't find it anywhere else. Songs like 'Let Me Rest on a Peaceful Mountain' or 'I Saw the Light' - that's my religion.

I don't adhere to rabbis, preachers, evangelists, all of that. I've learned more from the songs than I've learned from any of this kind of entity. The songs are my lexicon. I believe the songs. (https://www.newsweek.com/dylan-revisited -174056, our italics) 
Geir and Robert want to extend heartfelt thanks to Oddgeir Synnes (VID Specialized University), who initiated this project along with Geir.

\section{Literature}

Botvar, P. K. (2011). Se, han snakker ... Da 'Vinden’ blåste gjennom norske løvtrær. In P. K. Botvar, R. W. Kvalvaag \& R. Aasgaard (Eds.), Bob Dylan. Mannen, myten og musikken. Oslo: Dreyer.

Cott, J. (Ed.). (2017). Bob Dylan: The essential interviews. New York: Simon \& Schuster. Dylan, B. (2004). Chronicles. London: Simon \& Schuster.

Love, R. (2015). Bob Dylan - does the American songbook his way. AARP The Magazine, February/March.

Renza, L. A. (2017). Dylan's autobiography of a vocation. A reading of the lyrics 19651967. London: Bloomsbury Academic.

Trager, O. (2004). Keys to the rain. The definitive Bob Dylan encyclopedia. New York: Billboard Books.

Williams, D. (1984). Bob Dylan. The man, the music, the message. Old Tappan, New Jersey: Flemming H. Revell Company. 



\title{
CHAPTER 1
}

\section{"Señor (Tales of Yankee Power)": A Window into Bob Dylan's Existential and Religious World}

\author{
Reidar Aasgaard \\ Professor, idéhistorie, IFIKK, Universitetet i Oslo \\ Professor of History of Ideas, IFIKK, University of Oslo
}

\begin{abstract}
Señor (Tales of Yankee Power)" is a central song on Street-Legal, the album Bob Dylan released in 1978, a short time before his Christian conversion experience and the so-called Christian album trilogy of 1979-1981. Within the setting of a journey through a half-real, half-mythical landscape, the song describes an encounter between an I-figure, the singer, and his travel companion, a mysterious, silent "señor", with the singer going through a process of growing frustration leading to a state of existential despair. The article gives a close, narrative reading of the lyrics and analyzes the song within the contexts of the album, of the development of Dylan's religious language, of his performances of the song from 1978 to 2011, and of his own comments on it. The main conclusion is that "Señor" can be read in different ways, but that religion, and Christianity in particular, plays an important and integral part in the various readings. The song reflects Dylan's artistic and personal situation at the time, also by foreshadowing his conversion experience, but at the same time belongs within a long trajectory of Dylan songs from the 1960s until today which deal with fundamental human themes related to history, society, social relations, religion, and life in general.
\end{abstract}

Keywords: Bob Dylan, Christianity, Bible, literary analysis, contextual analysis

Samandrag: «Señor (Tales of Yankee Power)» er ein sentral song på Street-Legal, albumet Bob Dylan gav ut i 1978, kort tid før sitt kristne gjennombrot og den såkalla kristne albumtrilogien frå 1979-81. Songen skildrar ei reise gjennom eit halvt verkeleg, halvt mytisk landskap, der eit «eg», songaren, fleire gonger vender seg til reisefellen sin, ein mystisk, taus «señor». I samtalen gjennomgår songaren ei utvikling; frustrasjonen hans veks til eksistensiell desperasjon. Artikkelen gjer ei narrativ

Citation of this chapter: Aasgaard, R. (2019). "Señor (Tales of Yankee Power)": A Window into Bob Dylan's Existential and Religious World. In R. W. Kvalvaag \& G. Winje (Eds.), A God of Time and Space: New Perspectives on Bob Dylan and Religion (p. 17-46). Oslo: Cappelen Damm Akademisk. https://doi.org/10.23865/ noasp.74.ch1

Lisens: CC BY 4.0 
nærlesing av songteksta og analyserar songen ut frå ulike perspektiv: albumet som heilskap, utviklinga i Dylans religiøse språk, framføringane hans av songen frå 1978 til 2011, og hans eigne kommentarar til songen. Konklusjonen er at «Señor» kan bli tolka på fleire måtar, men at religion, og kristendom spesielt, spelar ei sentral og ufråkommeleg rolle i dei ulike tolkingane. Songen speglar Dylans kunstnarlege og personlege situasjon på den tida og kan også lesast som eit varsel om omvendinga hans. Men samtidig høyrer «Señor» til i ei tradisjonsline av Dylan-songar heilt frå 1960-talet og fram til i dag, der han tek opp grunnleggjande menneskelege tema knytt til historie, samfunn, sosiale relasjonar, religion og livet generelt.

Stikkord: Bob Dylan, kristendom, Bibelen, litterær analyse, kontekstuell analyse

\section{Introduction}

Most of Bob Dylan's songs can be heard in multiple ways. How they are interpreted - whether by scholars, fans, or others interested in Dylan differs widely, and very much depends on the interests and approaches of the interpreters. This is also the case with the beautiful, intense, and fascinating "Señor (Tales of Yankee Power)", and many have presented their readings of it. The song, which appeared on the 1978 album Street-Legal, is in my view an important contribution to Dylan's large songbook. And in addition to being of much value in itself, the song also has qualities that make it well suited as an access point to Dylan's existential and religious world in general.

Very roughly, we may sort current interpretations of "Señor" into some main types: as a historically oriented song, from a time of American settlement; a story about migration and ethnic tension, in the past or in the present; a description of lost love; a portrait of human uprooting and homelessness; a portrayal of the inner existential or religious crisis of an individual; or, finally, as an autobiographical account of Dylan himself, as an artist or a person. Often, these types of readings are combined, but with varying emphases. Earlier treatments of the song have usually been brief and sketchy, and no in-depth analysis seems to exist, see for example Webb (2006, p. 78-79); Heylin (2011, chs. 25-26); Gilmour (2011, p. 74-76). ${ }^{1}$ 
In the following, I shall not argue in favor of a specific interpretation of "Señor". In my view, a full or consistent reading of "Señor" is not possible: the song is inherently polyphonic. Instead, I approach the song in a more heuristic and experimental way: I shall use it as a window into central aspects of Dylan's existential and religious world as a whole. At the same time, I will inquire into how this world can help us understand the song; in this way, I also aim at adding some new perspectives to the interpretation of this significant song.

My point of departure will be in the text itself, in a narrative analysis of the lyrics. On the basis of this, I widen the perspective to take in the whole of Street-Legal, in a reading of the song in the context of the album. Then, I go on to situate "Señor" within the development of the religious language in Dylan's work in general, from the early 1960s and to the present. From this, I take a slight turn toward Dylan's own use of the song over the years. In doing so, we move in the direction of his artistic engagement in "Señor", in the function it has had in his performances. Finally, I address Dylan's own comments and reflections on the song, particularly during the first years after the release of the album; with this, we are within the realm of the personal, which includes both Dylan's artistic intentions with the song and its role in his own biography. As noted, focus will throughout be on existential and religious aspects, and particularly on the Christian element, which is predominant in the song. Importantly, however, these aspects are closely interwoven with other central motifs in the song, and I shall also pay close attention to this interplay.

With this procedure, I cover most of the breadth within which "Señor" has been interpreted, from mainly literary, text-centered approaches, via historical or more contemporary interpretations, and to autobiographical readings. To my knowledge, this is a new way of inquiring into the song. Within the limited format of a single chapter, some aspects of the song must be left out. For example, I shall not touch on musical elements, such as the tune and arrangement of the song, or on differences in Dylan's performances of it, interesting as these aspects may be. Also the reception history of the song, with its manifold interpretations, must mostly be passed over in silence. 


\section{Narrative analysis of "Señor"}

Here, I take my point of departure in the album version of "Señor", which differs a little from the print and online version; Dylan (2016, p. 390). ${ }^{2}$ The album version seems to me to be poetically superior, but the differences do not affect my reading of the song (see transcription with notes in appendix 1).

The full title of the song, "Señor (Tales of Yankee Power)", is not part of the sung version, but is an apt place to start. As noted by many, the word "Señor" is ambiguous: it can in Spanish be a polite address both to a male person in general, "mister", and to a superior, "master", but it can also be addressed to God or Jesus, the "Lord", in the form of a prayer. Most likely, it refers to "master" or "Lord"; as I will argue in the following, the use of the term in the song is probably intentionally ambiguous. Interestingly, the fairly obvious title "Señor" has a subtitle added in parentheses: "Tales of Yankee Power". When Dylan speaks of the song in 1978, he consistently uses this only. The subtitle may signal that the song is to be interpreted as dealing with American history or contemporary society, with "Yankee" commonly referring to people from the US. When used by outsiders, for example by Latin Americans, the word is often employed in a derogatory sense. Since "yankee" is used as epithet describing "power", such a negative connotation is probably implied.

The word "tales" is also interesting; it indicates a narrative, but not necessarily of a historical kind - rather, "tale" suggests that the song will contain a "story", or even some sort of "adventure", maybe from a distant past, such as the time of settlement in the West. The plural "tales" comes as a surprise, since the text mainly deals with one individual. The plural, however, may signal that the tale is representative of other people, maybe even of many other people. Or it can suggest that the song is about the fates of the main figures, each of them being victims of "yankee power".

For Dylan, it is quite rare to have such parenthetical subtitles, and in particular with formulations not taken from the lyrics themselves; he may have had a specific purpose for this. The fact that Street-Legal's final

2 See https://www.bobdylan.com/songs/senor-tales-yankee-power/ 
track, "Where Are You Tonight? (Journey Through Dark Heat)", has a similar twist, can support this. Is it to direct the attention to some story from the past? Or to conjure up a story, or stories, about human lives or the human condition generally? Or can it even be an attempt at diverting listeners from something else that the story is also about? It may be for any of these reasons, and even all of them. In any case, the bracketed text gives little support to a primarily religious reading - it may rather discourage it. This is a matter that I shall return to later.

Contrary to what "tales" in the title suggests, the lyrics of "Señor", which consists of seven four line verses, elude a straightforward logical or narrative analysis. Like many other Dylan songs, they present a situation, or some kind of state of mind, with chronological leaps back and forth between past, present, and even a potential future. Nevertheless, some features stand out. First, there is more structure to the lyrics than some interpreters, such as Williams (2004, p. 115), have assumed. Five of the verses, 1-2, 4, 6-7 (the two first, the middle, and the two last), are introduced by a repeated "señor", and all verses end with a question (except v. 6) and the address "señor". Verses 3 and 5 have a different structure; they are narratively more elaborated, and seem to function as bridges - this is also signaled in the tune of the song. Worth noting is also that these two verses may not be addressed to the señor, but rather to the singer himself or to the listeners. At the same time, they are through the characters linked up with verses 2 (a woman) and 6 (a gypsy and some "fools") respectively, but in opposite sequence, so that verse 3 develops what has been signaled in verse 2 (the woman), whereas verse 5 prepares for a conclusion in verse 6 (hard hearts). Narratively, this allows for a forward thrust in five steps $(1,2-3,4,5-6,7)$, while the song at the same time displays a markedly chiastic structure (1a, 2b, 3c, 4, 5c, 6b, 7a).

Furthermore, three central protagonists emerge in the song: first, the singer and main figure, who in my narrative reading should not be identified with Dylan himself. This character is on a journey, maybe like the one in "Where Are You Tonight?". The second character is the addressee of the song, the "señor". And the third is a woman of the past; she loved the singer, but has disappeared, or even seems to be hiding from him. She wore, and according to the singer "still" wears, "an iron cross ... around 
her neck". The singer's mention of the cross, a main Christian symbol, as a characteristic of her, shows that this is important for him. The "iron" epithet is somewhat ambiguous: it can connote stability and reliability, but also hardness and repulsiveness. The former interpretation is supported by her loving farewell: "Forget me not", the latter by the cross being paralleled in the preceding lines with a "wicked wind still blowin"” and a band "still playin" in a "vacant lot" - the word "still" being used three times.

In addition to the three main figures, some minor characters enter the stage, but only from verse 4 on. They are only hinted at, but generally appear to the singer as scary, or even threatening: the "marching band", maybe a funeral or military band; a strange "trainload of fools bogged down in a magnetic field", possibly his travel companions, and perhaps some kind of parallel to a "ship of fools"; a mystic "gypsy with a broken flag and a flashing ring"; and a "dragon", strongly present in the smell of its tail, and even ominous: the phrase evokes the end-time dragon of Revelation 12:3-4 in the New Testament.

Obviously, the central relationship is between the singer and the señor, whereas the longed-for woman is - at least explicitly - only important in the second and third verses. In the structurally corresponding fifth and sixth verses the attention turns instead to the other, minor characters: the fools and the gypsy. Now, the woman's loving care, "she held me in her arms" (v. 3), seems to be replaced by their "hard as leather" hearts (v. 6). The singer has at this point not only been separated from his woman, but is also alienated from, and feels opposed by other people.

The singer's relationship with the señor is unequal, even incongruous he seems to be a stranger to the singer, a quite distant figure. On the one hand, the señor is clearly in charge: he is expected to know the singer's past and the destination of the journey (v. 1), where the woman is (v. 2), whom to contact (v. 4), and even the hearts of the singer's opponents (v. 6). In five of the verses the singer repeatedly addresses the señor from a subordinate position: he needs his help and guidance, and waits for him to be ready. The singer clearly considers his power to be of an extraordinary, possibly even superhuman, nature. On the other hand, the señor is, throughout, passive: he does not respond to the questions and does not at any time speak. His silence is also mirrored in the questions of the singer, 
which increase in drama from verse to verse, even to a state of despair: from bewilderment and anxiety (vv. 1-2), to suspense and the unpleasant feeling of being exposed (vv. 4-5), and then to a personal collapse and, ultimately, an existential trauma (vv. 6-7). In the last two verses, the singer seems forced to the point of challenging the señor: here, the singer does not pose a question, but intimates that he is even more prepared than him (v. 6) and urges, nearly demands, the señor to join in for a drastic breakout - waiting is not possible any more (v. 7).

As indicated in verse 1 , the two main characters have started out on a journey, but with the singer not knowing where: "señor, can you tell me where we're headin'?" The first destination mentioned is Lincoln County Road, which can refer to various routes: there are more than twenty counties named Lincoln in the US, and many roads with this name. The Spanish flavor of the song (cf. the song title and the musical arrangement) may refer to one of the southernmost counties of New Mexico, a state bordering on Mexico. It can also refer to a road that stretches from Plains in Georgia to Washington DC (Jimmy Carter was president at the time of writing). Far more important, however, than the possible whereabouts of the road, is probably the word "Lincoln", with its reference to Abraham Lincoln, the president who abolished slavery in America. The road is also described as a place, a goal in itself, rather than as just a means of transportation; it appears to represent a state of potential and promise.

The other destination is Armageddon, a place referred to once in the New Testament, in Revelation 16:16, and interpreted in some Christian traditions as the scene of the final end-time battle between good and evil. As a geographical location, it may have a historical origin, but in the song, as in the New Testament, it is of a mythical and apocalyptical nature. Both destinations thus refer to, and consequently situate the events in the song in, a mixed landscape of myth and reality. Together, they forebode a fulfilment of a final and decisive character.

It is also worth considering that the two places need not be different or opposite options. Contrary to what most interpreters assume, the singer can also perceive them to be the same, so that Lincoln County Road ironically will turn out to be the way to catastrophe, to Armageddon. This would even heighten the drama which he anticipates. 
The travelers' means of transportation is not clear. It may be on horseback (v. 2: "ridin"), which signals a historic, possibly a migration or settler, situation for the song. This is supported by the mention of a "painted wagon", as in the 1969 western musical "Paint Your Wagon" - Dylan's lasting interest in film is well known. But the lyrics may also refer to a boat or a bus, cf. "upper deck" (v. 3), or more likely to a train, cf. "trainload" (v. 5) - "train" is a metaphor Dylan uses repeatedly, interestingly also in the final song on Street-Legal, "Where Are You Tonight?", and on the next album, the 1979 Slow Train Coming. At the same time, there is a gradual change of metaphor in the lyrics from journey to place. This is signaled already by "door" in verse 2 , and by "here" in verse 4 (as opposed to "there" in verse 2).

This transition in use of metaphor becomes manifest in the two last verses: here, the journey motif is gone, and the singer is in a room, even lying on the floor (v. 6), locked up in a space void of meaning: "this place don't make sense to me no more" (v. 7). What may have been a journey of promise has instead ended in a cul-de-sac, a standstill. The singer has appeared to be moving but is in reality standing still. And in this claustrophobic state the option is not to search or run, but to break out. Drastic change is needed: a disconnecting of cables like those of an amplifier or those between train wagons, and a turning of the tables like Jesus's action in the temple of Jerusalem (e.g. Gospel of John 2:13-16). The biblical reference can imply a change on an individual as well as on a societal level, considering the public nature of Jesus's act. Again, as with the travel destinations, Dylan combines biblical and modern references.

To sum up: the lyrics of "Señor" are more sophisticated than has been generally assumed. They depict a flickering scenario, with the main character, the singer, being on the verge of a dramatic change, and with the other main character, the superior "master", remaining silent in spite of the singer's many appeals to him. The drama intensifies as the singer gradually loses control of the situation, with a personal breakdown close at hand. The singer vacillates between looking back at a past of love lost and of scary creatures, envisioning a future of uncertainty and great anxiety, and experiencing a present which is increasingly unbearable: he senses himself to be both in motion and at a standstill, on his way 
but with no way out. In addition to the portrayal of the singer, elements from American history, biblical imagery and expressions, and real and unreal geographical places are mixed together in ways that underscore the confusion and unrest of the singer. Together, the structure, figures, references, and motifs add up to a song that presents a coherent, growing drama, while at the same time lending itself to a variety of interpretations.

\section{"Señor" within Street-Legal}

My analysis so far has offered some indications of possible readings of "Señor", not least based on its historical, geographical, and biblical references. Now, we turn to the contexts of the song to see how they can throw light on an interpretation of it. The most immediate context is the position and function of "Señor" on Street-Legal. The album, which was recorded April 26-May 1, 1978 and released June 13, has received quite mixed reviews. As far as artistic quality is concerned, assessments have varied from markedly negative to positive; for example Gray (2000, p. 215-30); Williams (2004, p. 113-17). In my view, the songs are both lyrically and musically somewhat uneven.

Like several other Dylan albums, Street-Legal does not have a clear organization or dramaturgy (see appendix 2 for track listing). Nevertheless, some elements tie it together. First, and most important here, two main themes run through its lyrics, partly separate and partly mixed: dramatic change, either recent, imminent, or potential - see also Burns (2008, p. 77-82) - and love, either hoped for, conflictual, or lost. Change comes particularly to the fore in "New Pony", "Señor", and "Where Are You Tonight?", and love in "Baby Stop Crying", "Is Your Love in Vain?", "True Love Tends to Forget", and "We Better Talk This Over". Both themes are prominent in "New Pony" and "We Better Talk This Over", but even more so in "Changing of the Guards" and "Where Are You Tonight?"; in these, the two themes appear to a degree of despair ("desperate men, desperate women" and "my despair") - and the same is, as I showed above, also the case in "Señor". Thus, change and love emerge as closely intertwined: each of the songs and the album as a whole bear witness to a stage of transition, where love - in a variety of meanings - may be found or, 
equally often, lost. In both respects, the lyrics throughout depict a state of unrest: the singer is partly impatient, partly overwhelmed - there is "no time to think". In spite of the album's unevenness, the two themes give Street-Legal a certain - though somewhat rent - cohesion.

Furthermore, the sequence of the songs underscores the same: the fact that "Changing of the Guards" is placed first signals the centrality of change, with obvious links to "Señor" and to "Where Are You Tonight?", the final song. This sets the change theme up-front and creates a link, an inclusio, from beginning to end. In the original vinyl version, "Señor" is number two on side $\mathrm{B}$, a relatively inconspicuous position. Here, it is sandwiched between other songs that deal with love relations of differing, but in all cases challenging, kinds. In the preceding song "Is Your Love in Vain?", the singer is clearly in love, but reserved and distrustful: he is not confident that his love is genuinely returned by the other, a female who is to meet both his physical and his emotional and/or existential-spiritual needs (cf. "my pain"). He has also repeatedly experienced being let down by others. Still, he is, in his longing, willing to commit himself. As in "Señor", a negotiation takes place: "All right, I'll take a chance, I will fall in love with you".

In "True Love Tends to Forget", the song after "Señor", love is also challenging: the singer and his "baby" are in a relationship, but a conflictual and strained one. In order to persevere in it, he no longer has the option to forgive but only - the less satisfying option - to forget. Here, too, a negotiation is going on, but the singer is more resigned than in the two previous songs. Interestingly, "True Love” appears in its penultimate line to link back to the Latino mood of “Señor": “Don’t keep me knockin' about from Mexico to Tibet".

Finally, both the title and the cover of Street-Legal signal change as a main theme. Being "street-legal" suggests that a person - like a car or a motorcycle - has acquired the qualifications and right to move freely about in the "streets", in the world, and is ready for something new, for example a new love affair. The photo on the front cover intimates the same, with Dylan standing in the door opening of his Rundown Studios in Santa Monica, California, looking to the left at the street, as if watching out for something to pass by or for someone to turn up. 
Characteristic of Street-Legal as a whole is also the central position of "I" and "you" figures. In the analysis above, I have implicitly assumed that the "I" - the narrator - of the lyrics, the singer, is the same throughout. This need not be the case, however: they can also be seen as diverse narrators. If so, the album may appear less coherent. But not much: the I-figures can then be viewed as staging different situations of challenge in the conflict between experiences of love and change. In my view, there are good reasons for seeing the I-figures as related throughout. The "I" is, for instance, for the most explicitly depicted as male. More important is the fact that an I-figure is central in each and every song on the album, both as an observer and an agent. It is very common for Dylan to have an I-figure in his songs, but on Street-Legal this feature is more prominent than on any other album. The "I" should, however, be seen as a narrative tool and not be equated with Dylan himself - at least not in this stage of analysis.

In nearly all Street-Legal songs there also appears a "significant other", a "you", either linked to or opposed to the I-figure. In most of them, they appear to be female. Usually, the female is portrayed in sensual or fleshly ways, but she also occasionally takes on a more-than-human character, either diabolical, such as Lucifer in "New Pony", or dreamlike, such as the woman in "Where Are You Tonight?". The male you in "Señor" is an exception, but a special exception, considering this character's ambiguous, both earthly and otherworldly, nature.

Whereas an otherworldly dimension is only hinted at in the description of the main figures on Street-Legal, it is strongly present in the album's numerous metaphors; throughout, they evoke a bewildering partly surrealistic, partly apocalyptic - scenario. The many mundane, everyday-like human negotiations and conflicts described in the songs are again and again clothed in existential-religious language taken from various traditions: Afro-American ("voodoo" in "New Pony"), AmericanIndian (“Cherokee” in "Where Are You Tonight?"), gypsy ("gypsy” in "Señor"), and others. The great majority of such metaphors and concepts, however, are drawn from the Bible and Jewish-Christian tradition; many of the biblical references are listed in Gilmour (2004, p. 116-17). They permeate the album from beginning to end; examples are "the good 
shepherd", "moving mountains", "wheels of fire", "betrayed by a kiss", "sacrifice", "the Babylon girl", and "enemy within". The mention of an original, but now forfeited, paradisiac state serves to frame the album as a whole: in the first song is "Eden ... burning", and in the final song the I-figure has bitten a "forbidden fruit". Paradise, the longed-for place of love, is endangered, maybe even destroyed by change.

Together, these elements - the themes of change and love, the depiction of the main characters, and the biblical references - emphatically strike a key with religious overtones, and disclose an existential urgency that not only permeates "Señor", but also Street-Legal as a whole.

\section{"Señor" in the development of Dylan's religious language}

My analyses of "Señor" and Street-Legal have indicated that existential and religious concerns play an important part at this stage in Dylan's artistic oeuvre. Thus, it is now appropriate to take a look at his songs as a whole, and reflect on how "Señor" may fit in with the general development in Dylan's songbook. To stay focused, I shall pay attention to one of the main ways that religion finds expression in his songs, namely through his use of biblical material. Dylan has from the early 1960s continuously been referring to the Bible, whether by means of quotations, allusions, or metaphors. As I have argued elsewhere, his relationship to Scripture has gone through six stages; Aasgaard (2011). Each stage does not rule out the preceding ones, however, but generally follows up on and complements them in a process of gradual development and maturing; see Taylor and Israelson (2015) and Marshall (2017) for more biographically oriented approaches.

The first stage goes from Dylan's debut album in 1961 to circa 1966, after Blonde on Blonde. In this period, Dylan uses the Bible primarily in the service of social and economic criticism, and in a manner similar to spirituals and the blues, with references to well-known biblical phrases, such as "the first one now will later be last" ("The Times They Are A-Changin"”), and to biblical figures, for instance "like Judas of old" ("Masters of War"). 
The second stage is from 1966 to 1973, when Dylan has stepped out of the limelight. During these years, he studies the Bible more intensively and develops a deeper understanding of ideas and concepts in it and of Jewish and Christian traditions in general. Here, the Bible serves as a reservoir for interpreting life and the world more generally. Dylan's use of biblical motifs, figures, and events becomes more varied and multivalent, with different motifs often being woven together. This is particularly visible on John Wesley Harding (1967), by Dylan himself referred to as "the first biblical rock album". By far the most famous example is "All Along the Watchtower", which has allusions to a broad range of writings from the Hebrew Bible, particularly the prophet Isaiah and the Psalms, and from the New Testament, especially the Gospels and the Revelation of John.

During the next period, from 1973 to 1978, the year of Street-Legal, the Bible appears to affect Dylan more personally. This is privately a demanding period, with his divorce from Sara Lownds in 1977. In addition to the Bible, other religious traditions also influence him, with examples on the album Desire (1976), most typically "Isis" and "One More Cup of Coffee (Valley Below)”. Dylan's personal involvement with religion is also evident in the sincere "Forever Young" on Planet Waves (1974), which echoes blessings in the Hebrew Bible and in synagogue rituals. It is also evident in the self-comparison of the I-figure with Christ in songs like "Idiot Wind" and "Shelter From the Storm", both on Blood on the Tracks (1975), and - as argued above - in the many biblical references on Street-Legal.

The fourth phase, 1979-81, is Dylan's charismatic-Christian time of "Sturm und Drang", with three albums steeped in biblical language, with frequent renderings of stories from the Torah and the Gospels, and extensive references to sayings of the prophets and of Jesus, and to the letters of Paul and the Revelation of John. This stage reaches its peak in personal engagement on Saved (1980), which is the one of the three albums to come closest to being a full-fledged gospel album. Just like in the earliest stage, Dylan uses the biblical material to criticize social and economic injustice, but now he also employs it for an explicit call to personal conversion.

The next period, from late 1981 and Infidels (1983) to the early/mid-199os, is artistically very uneven and shows a vulnerable Dylan with the expressive 
fervor gone. His major album here is undoubtedly Oh Mercy (1989), on which he appears religiously and personally more integrated, and - as on Street-Legal, but even more - makes use of biblical imagery and motifs to describe relationships, whether with one's own self, other humans, or with God, as in "Ring Them Bells". There also appears to be a running thread of self-scrutiny from "Señor" via "Every Grain of Sand" (1981) and to "What Good Am I?” (1989), evolving from existential confusion via self-doubt to more ethically colored self-criticism - in all three songs this is clothed in biblical language.

The final period, from the mid-199os and until the present, is the artistic culmination of Dylan's use of Scripture. Here, the elements from the previous periods, such as biblical metaphors and allusions, are woven together with other kinds of material, in particular literary and historical, in ways more integrated and holistic than in any of the earlier periods. Differently from the other periods, however, the singer appears more resigned, but also at the same time more lenient. He is less proclaiming than in the years 1979-81, but maybe even more biting in his criticism of social injustice and human folly. Examples of such songs are "Things Have Changed" (1999) and "Scarlet Town" (2012). In the latter, which takes its point of departure in the old ballad "Barbara Allen", a broad range of biblical imagery is mixed together with references to American history and to present social and political injustice into a somber portrait of a world gone astray.

As can be seen, "Señor" fits in well with this chronological survey of Dylan's religious, in casu biblical, language. The song is closely reminiscent of his use of biblical figures and texts in the 1960s, with references to God, the "Lord", and to Jesus and the cleansing of the temple being the most obvious examples. At the same time, something is new in "Señor": the material is applied to the singer - the finger in 1978 is not primarily pointing at others but at the I-person - what was once employed as socio-cultural reproach has here been redirected into a personal showdown. In the post-charismatic stages after 1981, but perhaps most pronouncedly from the late 1990s, both these aspects are taken further: the last two decades have witnessed a return to, and more mature continuation of, what is reflected in "Señor" and generally on Street-Legal. Differently from then, however, Dylan now more commonly describes the 
existential condition of his I-figures not as a close-to-traumatic standstill, but as a walk in perseverance: a main and recurring motif in his songs in this period is of a wandering, a pilgrimage in a life and in a world that are both aging. Typical examples are "Highlands" (1997), "Cross the Green Mountain” (2003), and “Ain't Talkin”" (2006).

In this trajectory of stages, 1979-81 emerges as a deviation from what had been, but also as a stepping stone to what was to come: all in all, the continuity in Dylan's existential and religious sensibilities from the pre-1979 stages - including "Señor" - and to the later stages seems to be stronger than with the 1979-81 charismatic Christian period.

\section{"Señor" in Dylan's Performances}

In his career, Dylan has been very conscious in his selection of songs for concert performance. This is reflected in how he has standardized his repertoire for parts of, or whole tours, particularly in recent years. In my view, Dylan's selection of songs functions as statements of his own position as an artist: he does not base his setlists on what the audience may expect, but primarily on what message he wants to mediate. This makes his shows an ideal object for a performance study approach: he has developed his persistently austere shows into an artistic expression of his own, cast in a mold I would term Dylan's "performatology". On stage, his main means of communication are the selection of songs and his manner of presenting them. Thus, the frequency, periods, and occasions of his performances of songs give valuable hints as to what songs he holds in regard and his motivations for using them. It is important to note here, however, that there are also several songs Dylan values highly, but which he has rarely or never played live, due, for example, to their length.

In the following, I shall inquire into how "Señor" has functioned to color Dylan's performances existentially and religiously. According to the listings, which are not quite consistent, Dylan has played "Señor" 265 times from 1978 to 2011 (74 of these were in 1978). This puts it in circa position sixty in the ranking. ${ }^{3}$ This is not very high, but nevertheless among 
his twenty percent most played songs, and on a level with several songs that he has performed since the early sixties.

Although Dylan, after the release of Street-Legal, expressed the view that he himself appreciated the album as a whole, "Señor" is the only song to survive 1978 in concert. Apart from "Señor", the most cherished has been "Changing of the Guards", which he played 68 times that year, 1978, in fact in each and every concert from July 5. Three of the other songs Dylan has performed thirty to forty times, two others half of that, and the two remaining have never been played in public. Thus, Street-Legal in retrospect appears as an intermezzo in Dylan's album catalog.

When dealing with Dylan's performance of "Señor", I distinguish between the years 1978 and 1980-2011, since the song in these periods serves different functions in his shows. ${ }^{4}$ It is also worth noting that Dylan did not play "Señor" between late December 1978 and early December 1980. The main reason for this hiatus is his complete shift in repertoire from the first concert in 1979 (Nov. 1): he now only uses material from his new album Slow Train Coming (Aug. 18) and from Saved (released 1980). We may, however, also speculate - in a biographically oriented interpretation that the song in this period did not resonate with his present state: the "suspense" described in "Señor" had become a thing of the past and was replaced by the fervor of his new beliefs.

As for Dylan's use of “Señor” in 1978, his first performances were from June 1 and in seven warm-up shows in Los Angeles ahead of the release of Street-Legal (June 13); here, he presents it as a "new song" from his forthcoming album. In the 91 concerts from June to December, he performs "Señor" regularly; the only exception is the three weeks from October 9 and for the rest of the month - here it is suddenly omitted (except for Oct. 28). In the shows up to October 9, the song is usually played around the middle of the second part, in a less conspicuous position.

During the summer and early autumn tours, the dramaturgy of Dylan's setlist, which is fairly stable throughout, appears to focus on change - a main motif on Street-Legal. The shows almost invariably start with "My Back Pages" ("I was so much older then / I'm younger than 
that now") and ends with "Changing of the Guards" as an encore, with "Forever Young" - a blessing song - serving as the finale. From October 18, however, Dylan revises the repertoire: he introduces "The Times They Are A-Changin"' into the shows and puts it in first position in the second part of the show, thus strengthening the motif of change. On November 1, "Señor" is back for the whole last part of the tour, until December 16. Now, however, Dylan has rescheduled the song from the middle of the second part to a more prominent position, as the final song of the first part. With "Señor" placed there, the motif of change is highlighted even more. And, importantly, the emphasis on existential and religious aspects becomes very strong, with songs drawing heavily on biblical references at the end of the first part, the start and end of the second part, and as an encore (“Señor", “The Times They Are A-Changin"”, "Forever Young”, and "Changing of the Guards"). All these songs remain in the same position until the final concert in December.

With these repertoire adjustments from June to December, we observe gradual revisions, or maybe even leaps, in the dramaturgy of the shows, during which elements of change and of existential and religious coloring are clearly intensified. Something seems to be on the way, at least as far as the setlist and the positioning of "Señor" is concerned. The next section, on Dylan's own comments to the song, will further substantiate this.

When turning to the 1980 to 2011 period, we move to a new stage in Dylan's touring in which his charismatic-Christian fervor quickly fades out. Now, he gradually returns to his earlier repertoire, but also still makes use of several explicitly Christian songs. We may for this period expect that "Señor" will have a somewhat different function than in 1978. During these years, Dylan performs the song much less frequently; even so, there are some distinct patterns in his use of it.

In his late 1980 tour Dylan returns to some of his pre-1979 repertoire. At the first concert (Nov. 9), "Señor" is one of the five old songs that he picks up again - the others are the classics "Like A Rolling Stone", "Girl From the North Country", "Just Like a Woman", and "Blowin' in the Wind". Dylan performs "Señor" in all eighteen concerts of this tour - a clear indication of his appreciation of the song. Among the few old songs that he introduces, "Señor" appears to serve as a bridge, or even reconciliation, 
between his pre-conversion and his present post-conversion state. Then, in the summer tours of 1981, which mix recent Christian songs with older classics and material from the upcoming Shot of Love album, it is not on the setlist. But after the release of Shot of Love (Aug. 12, 1981), "Señor" is played again, in eight of twenty-seven concerts. In these shows, explicitly Christian songs take up about a third of the repertoire.

From January 1982 to late autumn 1987, years with few concerts, Dylan performs "Señor" only about ten times. However, other, more explicitly Christian songs are represented, particularly the self-reflective "Every Grain of Sand", but occasionally also the searching "Knocking on Heaven's Door" and the challenging "When You Gonna Wake Up". Thus, the existential and religious element is frequently present in the shows. From early winter 1987 and until February 1994, however, years of very active touring, Dylan rarely plays "Señor" - only five times. In this period, he mainly uses material from Oh Mercy (1989) and Under the Red Sky (1990), material from the 1960s, and some covers. He also regularly uses several of his explicitly Christian songs: in addition to those mentioned above, also "In the Garden" and "Gotta Serve Somebody". From 1982 to 1994, these songs seem to serve as statements of the religious message he wants to convey, together with other kinds of messages. During these years, "Señor" does not have such a function; it seems almost ruled out of the repertoire. At the end of this period Dylan's use of the 1979-81 songs also dwindles.

From April 1994 to September 1998, "Señor” turns up again, and far more frequently: Dylan plays it at one out of five to ten concerts, from eight to twenty-two times a year. During these years, he usually also performs one or two explicitly Christian songs at each concert, mainly "In the Garden", "I Believe in You”, and a few others. Thus, the religious coloring is again clearly present, with "Señor" now being one of the songs that make this audible. From 1999 until April 2011, "Señor" is performed irregularly, on the average six times annually, ranging from once in 2001 and 2008 to twelve in 2005. During these years, Dylan has a surge of new songs, with the albums Love and Theft (2001), Modern Times (2006), and Together through Life (2009), and he combines this material with classical material from the sixties and some from the early seventies. However, he 
relatively often also performs songs with a Christian or distinctive religious character, particularly "Tryin' to Get to Heaven", "Forever Young", "I Believe in You", "Every Grain of Sand", "Saving Grace”, and "Gonna Change My Way of Thinking".

From 1994 to 2011, then, "Señor" appears to have become part of an established stock of existential and religious songs that are fairly interchangeable: whereas there was, from 1980 to 1994, an either-or relation between "Señor" and the explicitly Christian songs, there is, from 1994 to 2011, a both-and relation. If this is the case, it marks a shift in the function of "Señor" from primarily describing an existential search to also stating, or even calling for, a religious conviction. Even though we should beware of making too much out of Dylan's use of the song, it is clear that "Señor" remained important for him also in the long period from 1980 to 2011. In any case, his use of "Señor" together with the explicitly Christian songs has served to broaden the palette with which Dylan as a performer portrays the existential and religious longings of human beings.

The last time Dylan performed "Señor" was on April 27, 2011. From then and to August 2013, he mixed songs from various periods, with "Forever Young" and "Every Grain of Sand" being the most explicitly religious representatives. In October 2013, he had a major repertoire shift, with the emphasis on songs from Time out of Mind (1997) and later, combined with covers from the "Great American Songbook", and a small selection of his own classics. Songs from 1979-81 now turn up only very occasionally. Instead, recent songs marked by biblical imagery fill the "religious slot" in the repertoire, with "Scarlet Town" and "Pay in Blood", both from Tempest, being the prime examples. In October 2017, “Tryin' to Get to Heaven" reenters the repertoire (last played regularly in 2012), and from July 2018 Dylan has performed "Gotta Serve Somebody" at most concerts. Thus, his repertoire shift in 2013 is not a change in orientation, since existential and religious motifs are central in the material he has performed also since then. And with "Gotta Serve Somebody" in the setlist from summer 2018, an explicitly Christian element has again resurfaced. So if Dylan continues to tour in the years to come, there seems no reason why "Señor" should not turn up again. 


\section{"Señor" as interpreted by Dylan himself}

Dylan has not himself written anything about "Señor". He has, however, commented on it both at concerts and in interviews, particularly during 1978-80 - and far more than on most other songs; Cott (2006); Crowe (1985). These comments give a view into Dylan's artistic and personal development on the way to his Christian breakthrough.

"Señor" is known already from a studio recording in December 26, 1977. It can have been written some time before this, maybe as early as summer 1977. Dylan is unreliable on this; at a concert July 12, 1978, he claims to have written it "about six months ago". What is important, however, is that the song predates his conversion experience in late November 1978 by about a year or even more. With the divorce from his wife Sara, the second half of 1977 was a difficult time for Dylan: he was reported to be "suffering" and in "a bad way"; Heylin (2011, p. 455). According to himself, however, he was, in hindsight, not in crisis in 1978, but in a "fine" state (Nov. 23, 1980); see Cott (2006, p. 279, 281-82). To what extent this was the case, is a matter of discussion. On a psychological and a social level, he seems to have regained a foothold, and he describes his conversion as coming upon him as a surprise and not as a result of being "down" or the like. Interviews at the time, however, in January and March, suggest that he was on the move existentially and religiously. He speaks of magic, Karma, Christ, death, and the devil, and states "that he feel[s] a heartfelt God" and that he is "not a patriot to any creed", but "believe[s] in all of them and none of them"; Cott (2006, p. 181-85, 234-35, 259).

From the first show in June 1978 and for the rest of the year, Dylan consistently introduces his new song as "Tales of Yankee Power" - he seems deliberately to avoid using the full album title. ${ }^{6}$ At his June-July concerts in Europe, he makes occasional comments about the song, that it was written "after going down to Mexico" (June 26), or "on a trip through the southern part of the ... northern part of the States" (July 12). On the autumn tours in the US, he starts developing his comments, particularly about the origin of the song and about his own state, such as that he was

5 See http://www.bjorner.com/DSNo3550\%201977\%20sessions.htm
6 See "BobTalk", http://www.bjorner.com/still.htm 
traveling on a train from Monterrey in Mexico to San Diego in the US and that he "hadn't eaten for three days" before writing it (Sept. 16), later also adding Chihuahua, Mexico, to his geographical comments (Sept. 20). Later again, he states that he "fell asleep and ... woke up" and then wrote it (Sept. 29), and even that he "fell asleep for three days" (Oct. 4). Interestingly, a few days later, on October 7 he remarks that he "tried not to write this song, but I just had to" - and then, as I noted in the previous section, suddenly omits it for the rest of the month, while the rest of the setlist remains virtually the same.

These factors indicate that Dylan is ambivalent about "Señor": by commenting repeatedly on it, and more frequently than on most other songs, he betrays a special interest in it, but by referring to the context of writing (the "Tales" title and the Mexican setting) he seems to divert attention from other aspects of it; Sept. 27, he calls it "a little song". Somehow, Dylan appears in need of explaining it, and in a way that tones down its importance for him. The ambivalence is also apparent in his inner conflict between both needing and being unwilling to write it, and in his omission of it from the setlist.

For the first two weeks of November, Dylan occasionally repeats his geographical remarks about "Señor". Then, on November 13, he develops on the motif of being somehow compelled to write it, stating that "I can't tell you what it's about, I just know I wrote it"; the day after, he even maintains that "I found this song written in my back pocket", as if it had been given to him, or mediated unknowingly or subconsciously through him the song is not really his. Again, his ambivalence pops up: he seems shy, almost embarrassed about it, but at the same time under obligation, and even eager, to speak about and perform it.

Around mid-November, Dylan strikingly begins expanding three song introductions into some kind of short stories, or raps: first "Ballad of a Thin Man" and "One More Cup of Coffee (Valley Below)", and then "Señor". He repeats them in many versions and in almost all concerts for the rest of the tour; the intro to "Señor" occurs more than twenty times. The first occasion is November 17, in San Diego. It is noteworthy that this was the concert in which Dylan picked up a small silver cross thrown onto the stage and put it in his pocket - an incident frequently described 
in Dylan literature. The incident led up to his experience a couple of days later in an Arizona hotel room when he dramatically sensed the presence of Christ; see Cott (2006, p. 276). A year later, at his next concert in San Diego (Nov. 27, 1979), Dylan describes the incident, stating that he at the time was "feeling real sick" and getting "even worse", and then thanks the person who had thrown the cross. At the concert November 24, he wears a cross himself, possibly the same that he picked up a week earlier. Two days later he also exchanges the mention of "an Italian poet" in "Tangled up in Blue" with a reference to the Bible.

In the famous November 17 concert, Dylan, in the expanded "Señor" intro, briefly mentions the train travel, but then goes on to describe a person sitting next to him "wearing a blanket", seeming "to know everything", and his "eyes were burning up, smoke was coming out of his nostrils". Dylan wanted to talk to him, but when he "turned around to look at him, he was gone". According to Dylan, the man had either got off, or he himself may have been hallucinating. He repeatedly states that he eagerly "wanted to talk to" him. The next day, Dylan adds that he at first was all alone in the train car and that the man entering "looked to be about 150 years old". Two days later a family with twelve kids - in other versions up to 18 - enters Dylan's story, but they leave the train before the man gets on. Now the old man does not sit next to him, but takes a seat across the aisle, and Dylan mostly observes him with his own window serving as a mirror in the dark.

These are the main narrative elements until December 12; then the family is gone from the story (with a single return Dec. 16). The focus is now even more on the man, who is dressed only in a blanket (Dec. 1), has a long, stripy beard (Dec. 12), and is later even - almost comically equipped with a derby hat (Dec. 15). In most versions, Dylan is eager to talk with him, but not sure what to ask him about, and when he makes an attempt, the man has disappeared. In a couple of versions, however, Dylan is able to address him: "I finally got up the courage to talk to him. And the train started moving and the conversation went something like this" (Dec. 10, also 12), and then goes on to perform the song. Clearly, the man is in this instance identified as the señor. In some later versions, Dylan dwells on how he was himself affected by the encounter: "I felt this strange vibration" (Dec. 8, also 10, 15, and 16). 
In their core, Dylan's comments may reflect an element of truth about the song's origin, but this must here remain undecided. What is far more relevant for us is how the comments develop during the late summer and the autumn of 1978. In an early stage, up to mid-November, the comments on geography and other things seem to function as a diversion, some kind of cover-up for his existential strain, his "feeling real sick". At the same time, his remarks on his double-mindedness toward the song appear to be a letting out of some of the growing inner steam. The setlist adjustments in the second half of October, with more focus on change and on the religious dimension, whether made consciously or intuitively, also correspond well with this. Worth special notice are Dylan's remarks on his own state: his sleeping and not eating for three days and his ambivalence in writing the song echo biblical models, particularly the accounts of Jesus's death and resurrection, and the reactions of figures such as Moses, Jeremiah, and Paul, who are called by God, but reluctant to heed the call.

In a later stage, from mid-November, when Dylan suddenly starts developing his intro into this strange short story, other elements come into focus, primarily the old man, but also the big family. Since the first telling of the story coincides with the cross incident (Nov. 17), it cannot have been caused by it. Instead, it is far more likely that his "hotel room experience" triggered it, since the expansion of the story took place during just those days. Dylan's description of feeling a "strange vibration" in the encounter with the old man reminds of his meeting with Jesus: in an interview May 21, 1980, he describes the encounter with Jesus as "I felt my whole body tremble. The glory of the Lord knocked me down and picked me up"; see Cott (2006, p. 276), cf. also the similarity to the phrase "gotta pick myself up off the floor" in "Señor"; also Cott (2006, p. 281). Such accounts of response to encounters with the divine are common in the Bible, but also in other religious contexts.

Dylan's description of the old man also seems to be heavily influenced by biblical material, such as the smoke coming out of his nostrils (2 Samuel 22:8-10; Psalms 18:7-9; Job 41:20, about God and Leviathan) and his flaming eyes (Daniel 10:6; Revelation 1:15). Other elements may have other sources; the "blanket" can, for example, be borrowed from 
Dylan's “I Dreamed I Saw St. Augustine” (1967), in which Augustine is also said to have a "fiery breath". Dylan looking at the old man with the window as a mirror may draw on the idea that seeing God directly is perilous, or it may also be a borrowing from Paul (1 Corinthians 12:13).

Why does Dylan recite this strange - almost confused - story? And does he himself know what it is about? And how important is it for our interpretation of "Señor"? Again, no definitive answers can be given. In any case, the reciting of the long song intro is something quite different from a cover up; it appears instead as a trying out or veiled profession of what is going on within him, maybe almost inadvertently. Possibly, this revelation-like story - with its mixture of biblical and religious elements, personal experiences, and more or less conscious ruminations - can be described as an oral counterpart to the literary phenomenon of automatic writing, or a stream of unconsciousness/subconsciousness story. In the setting of the shows the intro appears to be a way of providing his audience, and maybe even more himself, with a - or, rather, one - key to the interpretation of the song. Together with other factors, such as the reorganization of the setlist, the intro also serves to underscore the central part "Señor" seems to have played in Dylan's own religious development during this period.

As I have noted, Dylan on some occasions during the 1978 tours intimated that he did not really know what "Señor" was about; he is also vague about the song in his liner note comments on Biograph; Crowe (1985, p. 57). It is not unlikely that this is true: the meaning of the song may very well have grown on him over time, or even dawned upon him. This also agrees well with his description of how other songs come to him, that he is some kind of a medium, and that they are given him from above: "sometimes I don't know what I'm writing about until years later it becomes clearer to me"; see Cott (2006, p. 241-42, also 263 and 268). Very likely, in the case of "Señor", Dylan's own artistic and creative sensibilities have forestalled his own digestion of what was going on.

This may of course be undue psychologizing. But I do not think it is: over the years Dylan has constantly been in discussion with, even wrestling with, many of his songs, musically as well as textually. He has revised and reshaped them again and again, managing to adapt them to ever new 
contexts. This is also the case with "Señor". But in a way that is different from most of his other songs, Dylan seems not to have been in control of it. Instead, the song appears to have defeated Dylan, and he to have surrendered to it. Read this way, "Señor" serves as an apt window into a crucial stage in Dylan's existential and religious development. Admittedly, this is not a totally new idea, but the discussion above develops on, and makes a far stronger case for this as a plausible reading of the song - at least as far as Dylan's biography is concerned.

\section{Looking out of the window, and beyond}

In this chapter, I have aimed at two things: first, to show how "Señor" can serve as an opening to the existential and religious world of Dylan, as this is visible both in his songbook and in his life as an artist and individual; and second, to bring out how "Señor" itself has been informed and shaped by this world, both in how it is similar to it and how it may stand out from it. As argued above, there is a very close interplay between the song and its various contexts. I shall round off with some reflections with this interplay in mind.

First, as for the understanding of "Señor": what has occurred to me as the main insight from my inquiry into the text and its contexts is the central role of religion. As I noted at the outset, "Señor" can be interpreted in various directions: as referring to American history, ethnic tension, forfeited love, human rootlessness, the crisis of an individual or even of Dylan himself. Each interpretation, and combinations of them, can find support in the song. Although I have offered some suggestions about how to read "Señor", my aim has not been to go for one specific reading or to add a new one. Instead, it has been to foreground the religious dimension of "Señor", since this dimension has turned out to be integral to the various readings of the song. The existential and religious elements - and the Christian one in particular - appear tightly interwoven with each reading and cannot be removed without loss in meaning. For example, the señor figure is obviously indispensable, and on more than one level: he can be a master from history, an ethnically superior - a yankee - but also Christ or God. The iron cross may be a reminder of people who left 
for America because of religious persecution, or of a lost and longed-for, almost otherworldly, lover. Armageddon may forebode an earthly or a personal mayhem, or the final combat between good and evil, and the overturning of the tables anticipate a fundamental social or individual upheaval. And so on. Even far into the area of Dylan's own artistic and personal life, these elements make sense, as I have argued above.

Second, as for the relation of "Señor" to the rest of Dylan's work: there are several ways in which this song directs our attention to other parts of his oeuvre. There are a number of songs that in similar ways weld religious elements together with historical narratives, with aspects of social and human relationships, or with the experiences of individuals, also his own. With its mixture of American and biblical-mythical history, "Señor" clearly belongs within a long and varied trajectory of songs from "Gates of Eden" (1965) and "I Dreamed I Saw St. Augustine" (1967) via "Blind Willie McTell" (1983), "High Water (For Charley Patton)" (2001), "Cross the Green Mountain" (2002), to "Scarlet Town" (2012). In its description of personal uprooting and homelessness, "Señor" has much in common with "Shelter from the Storm" (1975), "Oh, Sister" (1976), and "I and I" (1983), songs that all have a distinctive biblical coloring; in "Shelter from the Storm" the male I-figure is even said to be relieved of a "crown of thorn" similar to that of Christ.

Furthermore, in Dylan's songbook, there are few, maybe no other songs that describe an existential crisis with an urgency and energy comparable to "Señor". This is clearly one reason why so many cherish the song. Its energy is perhaps only paralleled by his most insisting Christian songs, such as "I Believe in You" (1979) and "Saved" (1980). Differently from them, however, "Señor" is more open and indefinite. In this, it seems more kindred to songs with less - at least pronounced - intensity, such as "Dear Landlord" (1967), where the singer also enters into negotiation with his addressee, "Every Grain of Sand" (1981), "What Good Am I?" (1989), and "Things Have Changed" (1999) - all songs marked by serious self-examination, and with many explicit biblical references.

During his career, Dylan has also taken much care to protect his autonomy and private life, and he has frequently warded off attempts at biographical readings of his songs. At the same time, many of them 
are clearly triggered by his own experiences. There is often only a thin membrane between his songs and his life; Dylan can in this respect be described as a "translucent" artist, despite his many attempts at rejecting this. Without doubt, this too is a reason for his appeal: people can recognize their lives in his songs, whether they are about relationships of love, about aging, or about death. Also within this personal, almost private, domain, existential and religious motifs emerge as central. Again, "Señor" may be an apt example, with its description of the lost, and now unattainable, lover - the female with an "iron cross". Here too, there seems to be a connection to songs about love and also about love lost, such as "SadEyed Lady of the Lowlands" (1966), "Wedding Song” (1974), "Sara” (1976), and to an extent even "Standing in the Doorway" and "Can't Wait" (both 1997), in which the women often take on close-to-celestial features.

Dylan has stated that many of his songs must be understood on different levels: "that's because my mind and my heart work on all those levels ... I don't want to be chained down to the same old level all the time" (Nov. 16, 1978); see Cott (2006, p. 269). As we have seen, this also holds good for "Señor". But characteristic of the song is, at the same time, the position religion, and Christianity in particular, has across these levels. The same is also the case with a great number of other songs in Dylan's six-decade-long career.

\section{Literature}

Aasgaard, R. (2011). Med Bibel i Babel: Den skriftlærde Dylan. In P. K. Botvar, R. W. Kvalvaag, and R. Aasgaard (Eds.). Bob Dylan: Mannen, myten og musikken (p. 145-65). Oslo: Dreyer.

Burns, J. (2008). Series of Dreams: The Vision Songs of Bob Dylan. Kirkcudbright, Scotland: Glen Murray.

Cott, J. (Ed.). (2006). Dylan on Dylan: The Essential Interviews. London: Hodder \& Stoughton.

Crowe, C. \& Dylan, B. (1985). About the Songs: Liner Notes and Text to Biograph (album liner notes). New York: Columbia Records.

Dylan, B. (2016). The Lyrics 1961-2012. New York: Simon \& Schuster.

Gilmour, M. J. (2004). Tangled Up in the Bible: Bob Dylan and Scripture. New York: Continuum. 
Gilmour, M. J. (2011). The Gospel According to Bob Dylan: The Old, Old Story for Modern Times. Louisville KY: Westminster John Knox.

Gray, M. (2000). Song \& Dance Man III. London: Cassell.

Heylin, C. (2011). Bob Dylan: Behind the Shades. 2oth Anniversary Edition. London: Bloomsbury.

Marshall, S. M. (2017). Bob Dylan. A Spiritual Life. Washington DC: BP Books/WND Books.

Taylor, J., \& Israelson, C. (2015). The Political World of Bob Dylan: Freedom and Justice, Power and Sin. New York: Palgrave Macmillan.

Webb, S. H. (2006). Dylan Redeemed: From Highway 61 to Saved. New York and London: Continuum.

Williams, P. (2004). Bob Dylan. Performing Artist 1974-1986. London and New York: Omnibus (orig. publ. 1992).

\section{Web Resources (retrieved June 21, 2019)}

http://www.bjorner.com/DSNo3550\%201977\%20sessions.htm http://www.bjorner.com/still.htm http://www.bjorner.com/still.htm\#y79 http://www.dgdclynx.plus.com/lynx/lynx27.html https://bob-dylan.org.uk/archives/2566 https://bobdylansonganalysis.wordpress.com/2017/04/21/senor-tales-of-yankee-power/ https://www.bobdylan.com/setlists https://www.bobdylan.com/songs/senor-tales-yankee-power/ https://www.setlist.fm/stats/bob-dylan-1bd6adb8.html https://www.setlist.fm/stats/songs/bob-dylan-1bd6adb8.html?song=Se\%C3\%B1or $+\% 28$ Tales+of+Yankee+Power\%29

\section{Author description}

Reidar Aasgaard is Professor of Intellectual History at the Department of Philosophy, Classics, History of Art and Ideas (IFIKK), University of Oslo. He has published books and articles in English and Norwegian on the history of childhood, the New Testament, Late Antiquity, and early Christian apocrypha. He has worked as a Bible translator and translated classical texts from Greek and Latin into Norwegian. Aasgaard has also edited a volume on Bob Dylan in Norwegian (with Botvar and Kvalvaag) and since 2011 has been responsible for a popular lecture series on Dylan at History of Ideas. 


\section{Forfattaromtale}

Reidar Aasgaard er professor i idéhistorie ved Institutt for filosofi, idéog kunsthistorie og klassiske språk (IFIKK), Universitetet i Oslo. Han har gjeve ut bøker og artiklar på engelsk og norsk om barndommens historie, Det nye testamentet, seinantikken og tidlegkristne apokryfar. Han har arbeidd som bibelomsetjar og har omsett klassiske tekster frå gresk og latin til norsk. Aasgaard har også vært redaktør av ei bok om Bob Dylan på norsk (saman med Botvar og Kvalvaag) og har sidan 2011 vore ansvarleg for ei populær førelesingsrekke om Dylan på idéhistorie.

\section{Appendix 1}

\section{Señor (Tales of Yankee Power)}

Señor, señor, can you tell me where we're headin'?

Lincoln County Road or Armageddon?

Seem like I been down this way before

Is there any truth in that, señor?

Señor, señor, do you know where she is hidin'?

How long are we gonna be ridin'?

How long must I keep my eyes glued to the door?

Will there be any comfort there, señor?

There's a wicked wind still blowin' on that upper deck

There's an iron cross still hangin' down from around her neck

There's a marchin' band still playin' in that vacant lot

Where she held me in her arms one time and said, "Forget me not"

Señor, señor, I can see that painted wagon

Smell the tail of the dragon

Can't stand the suspense anymore

Can you tell me who to contact here, señor?

Well, the last thing I remember before I stripped and kneeled

Was that trainload of fools bogged down in a magnetic field

A gypsy with a broken flag and a flashing ring

He said, "Son, this ain't no dream no more, it's the real thing" 
Señor, señor, you know their hearts is hard as leather

Well, give me a minute, let me get it together

Just gotta pick myself up off the floor

I'm ready when you are, señor

Señor, señor, let's overturn these tables

Disconnect these cables ${ }^{c}$

This place don't make sense to me no more

Can you tell me what we're waiting for, señor?

a Lyrics 2016: 390 has “do you know where we're headin"”. This seems lyrically more flat and has a slightly different meaning.

b Dylan may here sing "it's a real thing”.

c The change in sequence of lines 1 and 2 in my view weakens the rhetoricalpoetical effect.

\section{Appendix 2}

\section{Track listing, Street-Legal (original vinyl version)}

Side A

1. "Changing of the Guards"

2. "New Pony"

3. "No Time to Think"

4. "Baby Stop Crying"

Side B

1. "Is Your Love in Vain?"

2. "Señor (Tales of Yankee Power)"

3. "True Love Tends to Forget"

4. "We Better Talk This Over"

5. "Where Are You Tonight? (Journey through Dark Heat)" 


\title{
CHAPTER 2
}

\section{"The Titanic sails at dawn": Bob Dylan, "Tempest", and the Apocalyptic Imagination}

\section{Robert W. Kvalvaag}

Dosent i RLE ved fakultet for lærerutdanning og internasjonale studier, OsloMet

Professor in religion, philosophies of life and ethics at the Faculty of Teacher Education and International Studies, Oslo Metropolitan University

\begin{abstract}
Tempest" is one of the longest songs Dylan has written. His point of departure is the Titanic disaster, but it soon becomes obvious that Titanic is a metaphor, pointing to something much bigger than the 1912 disaster. "Tempest" is a rich song in the sense that it contains references to many different sources. My aim is to try to uncover some of these, in order to detect how this vast collage is used to create a new story that transcends the original one. It comes as no great surprise that apocalyptic themes literally come to the surface in the song. In what ways does Dylan express his apocalyptic imagination in "Tempest", and how is this related to other songs in the Tempest album?
\end{abstract}

Keywords: Titanic, Titanic - the movie, apokalypse, watchman, redemption, judgment, "Roll on John"

Sammendrag: «Tempest» er en av de lengste sangene Dylan har skrevet. Han tar utgangspunkt i Titanics forlis, men det viser seg at Titanic er en metafor, som peker på noe langt større enn selve katastrofen i 1912. «Tempest» er en rik sang på den måten at den inneholder og gjør bruk av mange ulike kilder. Min målsetting er å avdekke noen av disse, for slik å finne ut av hvordan denne store kollasjen brukes for å skape en ny fortelling, som transcenderer den opprinnelige. Ikke overraskende dukker apokalyptiske tema opp i sangen. På hvilke måter gjør Dylan bruk av sin apokalyptiske tenkning i «Tempest», og hvordan forholder dette seg til noen av de andre sangene på Tempest?

Stikkord: Titanic, Titanic-filmen, apokalypse, vaktmann, forløsning, dom, "Roll on John"

Citation of this chapter: Kvalvaag, R. W. (2019). “The Titanic sails at dawn": Bob Dylan, “Tempest”, and the Apocalyptic Imagination. In R. W. Kvalvaag \& G. Winje (Eds.), A God of Time and Space: New Perspectives on Bob Dylan and Religion (p. 47-90). Oslo: Cappelen Damm Akademisk. https://doi.org/10.23865/noasp.74.ch2 Lisens: CC BY 4.0 
"Live now ... live before you board your Titanic". -Dylan (2005, p. 54)

Tempest is the $35^{\text {th }}$ addition to the Dylan catalog, and it was released on the fiftieth anniversary of the self-titled Bob Dylan from 1962. Columbia Records chose September 11, 2012, as the U.S. release date for the album. It was 11 years since Dylan had released Love and Theft, and 11 years to the day since the World Trade Center attacks. On "the fourteen day of April", one hundred years before the album came out, the Titanic hit the iceberg that sank it early the next morning. Maybe "Tempest" is Dylan's response to the $9 / 11$ attacks?

The Titanic disaster, like 9/11, was taken by many as a hinge moment in history. The loss of the great ship in 1912 marked the end of European triumphalism and the start of the general disaster that would culminate in the Great War. The attacks of 9/11/01 initiated a new phase of American and global disorder, the disastrous 'War on Terror'. It seems typical of Dylan's obliquity that he might respond artistically to $9 / 11$ by way of the Titanic. (Mentz, 2015, p. 162)

The song “Tempest” is Dylan's version of the disaster, and it both provides the title of the album as a whole and is clearly thematically central. One reviewer who wrote for the British newspaper The Daily Telegraph noted that there is a storm raging throughout this album, metaphorically and literally:

On a deceptively bright and breezy opening track, rattling railroad song "Duquesne Whistle", Dylan hears the train's whistle speaking with the sweet voice of «the mother of the Lord» and scream "like the sky's going to blow apart". Right there, in the confluence of religious faith and apocalyptic portent, Dylan establishes themes on one of his darkest, bloodiest and most foreboding collection of songs, set in a barren landscape of Godless self-interest, moral equivocation and random violence. (McCormick, 2012)

"Tempest" is Dylan's second-longest song (the longest is the 16-minute "Highlands"), on his longest album ever (68:31), and it has never been played live. It has forty-five verses, and each verse is an alternating quatrain, a four-line verse with an abab rhyme pattern. The last words of the b-lines (and sometimes the last words of the a-lines) rhyme with each other. 
Dylan sings verse after verse with very few breaks in between. There is no bridge in the song to break up this repetitive pattern. However, there are four verses (six, seventeen, thirty-eight and forty-five) where a dreaming watchman appears, each followed by a musical break. They make it possible to divide the forty-five verses into subgroups, which give the song a fourpart structure. I use this way of dividing "Tempest" in my analysis.

\section{Evaluating and researching "Tempest"}

In a 2012 interview with Rolling Stone, Dylan provided a lot of information about the Tempest album in general, and about the "Tempest" song in particular. Dylan pointed to the role tradition plays in his songwriting:

I can name you a hundred songs where everything ends in tragedy. It's called tradition, and that's what I deal in. Traditional, with a capital T [...]. Folk musicians, blues musicians did write a lot of songs about the Titanic. That's what I feel that I'm best at, being a folk musician or a blues musician, so in my mind it's there to be done. If you're a folk singer, blues singer, rock \& roll singer, whatever, in that realm, you oughta write a song about the Titanic, because that's the bar you have to pass. (Gilmore, 2012b, p. 50)

Critics have expressed very different views on whether Dylan did pass the bar or not. Some think "Tempest" is one of his best, while others call it one of his worst songs ever. In his review on www.allmusic.com Thom Jurek states that "the title cut retells the story of the Titanic with references to history - and the James Cameron film. Hearing it once is enough". In his biography Time Out of Mind: The Lives of Bob Dylan Ian Bell writes that too many of the verses are redundant, several are clumsily written and the song does not count as a musical treat. "Tempest" is too self-conscious, even obvious, as an excursion into folk tradition (Bell, 2013, p. 526-27). Commenting on the musical aspects of "Tempest" Philippe Margotin and Jean-Michel Guesdon in Bob Dylan All the Songs: The Story Behind Every Track complain that there is almost no variation throughout the song. The drama of the Titanic is not supported by any musical progression. Instead, a feeling of monotony emerges from the whole arrangement (Margotin \& Guesdon, 2015, p. 689). 
Richard F. Thomas disagrees with the critics who dislike "Tempest". He thinks this song is the culmination of Dylan's songwriting. In Why Dylan Matters he points out that the Carter Family's "The Titanic" is visible and audible on "Tempest". But out of this old song Dylan created a new one, and "the new song is something else, something that through Dylan's genius as a songwriter, singer and verbal painter, has transcended the folk tradition in which it is rooted; it has become both epic and cinematic, a wholly new genre" (Thomas, 2017, p. 116-117).

Although "Tempest" is a relatively new composition, it has already received attention from several critics, and also some scholarly scrutiny. In Bob Dylan: American Troubadour, Donald Brown emphasizes "the sense of momentous, apocalyptic event" in the song. He finds that this is amplified by the storyteller's choice of imagery (Brown, 2014, p. 231-32). Michael J. Gilmour, too, focuses on the apocalyptic dimension of "Tempest". In his view the song is "a metaphor of humanity's shared plight on the sea of chaos". Gilmour argues that the Book of Revelation is the key to the story Dylan tells (Gilmour, 2017, p. 71). On his website "Bob Dylan Song Analysis" David Weir has provided an interesting analysis of the song, and I have made use of some of his suggestions in my own interpretation. In her dissertation Bob Dylan and the End of the (Modern) World Christine Hand Jones sees "Tempest" as an expression of Bob Dylan's apocalyptic imagination:

This sprawling, ambiguous, bloody ballad incorporates all of Dylan's destructive vision, with its depiction of a symbol of modernity crashing into the sea, its collage of historical figures, its conflation of fact and fiction, dream and reality, cinema and history, and its harsh vision of total catastrophe. Above all, however, 'Tempest' returns the listener to the folk roots of Dylan's apocalyptic imagination. (Hand Jones, 2013, p. 201)

In his recent book The True Performing of It: Bob Dylan \& William Shakespeare Andrew Muir discovers that Shakespeare's The Tempest and Dylan's Tempest album share many characteristics. A more detailed investigation and interpretation of the song "Tempest" and The Tempest is provided by Heinrich Detering in Die Stimmen aus der Unterwelt: Bob Dylans Mysterienspiele. Detering compares Dylan's watchman to Shakespeare's 
Prospero; like the latter the watchman is no passive spectator but he is the director. In Shipwreck Modernity Steve Mentz argues that Dylan's song "maps out an almost perfect inverse of Shakespeare's play" (Mentz, 2015, p. 163). Mentz also describes the shipwreck in "Tempest" as the name of what he calls "the core experience": the shock and pressure of the inhuman world on human skin. Being in the world means living inside the shipwreck. The disaster is the story we need to explain, but cannot explain, and yet still have to tell (Mentz, 2015, p. 166).

Although my analysis of "Tempest" to a certain degree depends upon sources like the Titanic song tradition and the James Cameron Titanic movie, I employ this material not because I want to study the material in itself, but because it enables me to interpret the song as a whole. In my interpretation of "Tempest" I pay close attention to the views established by Brown, Gilmour, Weir and Hand Jones. However, except for Weir, none of them have attempted an extensive analysis of the song.

I want to provide an in-depth examination of “Tempest”, try to uncover some of the important sources in Dylan's text, and explore how this material is integrated into the song. From what tradition(s) did Dylan get the inspiration to write this song, and how does he use elements from different traditions to create his own text? The Bible has always been a chief source of inspiration for Dylan. It comes as no surprise that the Bible also plays an important role in Dylan's retelling of the Titanic story, "the title track 'Tempest' is studded with lines and images of the Bible" (Muir, 2019, p. 314). My main concern is to investigate the way biblical material and motifs are used by Dylan to create a new narrative, which transcends the historical events that took place on that fateful night in 1912. What is the theological significance of this narrative? What kind of text is "Tempest"? What role is played by the watchman, the song's main protagonist?

\section{The Carter Family and "The Titanic"}

Alvin P. Carter, his wife Sara, and Sara's cousin Maybelle, recorded hundreds of songs between 1927 and 1941. When they broke up as a musical group in 1941 Alvin P. and Sara had been divorced for several years, and she had remarried. In 1952, Alvin P. reunited with Sara musically, and 
from 1952 to 1956 he recorded 40 tracks for the Acme Record Company with his former wife. Among the songs they recorded in 1952 was "The Titanic", which was released on CD in 2008, on the album The Acme Sessions 1952/6. This is not a Carter Family song in the sense that it was written or composed by one of them. The Carters' core repertoire was songs their parents, families, neighbors and friends taught them. Alvin P. Carter's "method" was one adopted by many songwriters from Guthrie to Dylan. Alvin's niece Fern Salyer remembers him as a song catcher:

A. P. would go out and walk for miles and stay gone for a week or two at a time; went from house to house in different communities looking for songs. He rescued them; they were gonna be gone, and he'd take them and go home and maybe rearrange them. (MacMahon, McGourty \& Wald, 2017, p. 68)

In the first part of the twentieth century more songs were made about the sinking of the Titanic than any other single disaster (Sapoznik, 2007, p. 8). Especially in the rural southern parts of the USA singers and composers - both black and white - kept the memory and immediacy of the event fresh through numerous songs and performances. In the early 1920 Seth Newton Mize (1901-1977) wrote the song "The Titanic". ${ }^{1}$ Mize's song has eight verses. It entered oral tradition, and became a folksong during his lifetime. Several different artists recorded it, often without acknowledging Mize as the creator, most likely because he was not a very well-known writer (McNeil, 1988, p. 105-106).

The earliest recorded version of Mize's "The Titanic" is probably by Tom Darby and Jimmie Tarlton. Darby and Tarlton were one of the most popular country acts of the mid-1920s to the mid-1930s. They recorded "The Titanic" in 1930 with a slightly different lyric, as "After the Sinking of the Titanic". ${ }^{2}$ When they recorded the song, they put the blame on the captain and his drinking, because some witnesses saw Captain Smith in the saloon bar in the run-up to the collision:

Capt'n Smith must have been drinking

Not knowing that he'd done wrong

1 For Mize's lyrics, see Wolfe, 1997, p. 63-64.

2 For Darby and Tarlton's lyrics, see http://www.folkarchive.de/titan2.html 
While trying to win the record

He let the Titanic go on

In Mize's original text it was not the captain, but "the rich man, he must have been drinking". Another difference is that Darby and Tarlton substituted "the watchman" in Mize's text with "the porter". They also reduced the lyric from eight to six verses, and did not include Mize's verse about the band playing "Nearer, My God, to Thee" when they realized the ship was sinking. In Chronicles Dylan remembers listening to Darby and Tarlton in St. Paul, Minnesota in the summer of 1959. He was very impressed: "I always thought that 'A-wop-bop-a-loo-lop a-lop-bam-bo' had said it all until I heard Darby and Tarlton [... They] were out of this world" (Dylan, 2004, p. 241).

When Alvin P. and Sara Carter Bayes recorded the song the lyrics had changed once more. ${ }^{3}$ In some ways it is closer to the Mize original, but in other ways it is closer to the lyrics of the Darby and Tarlton song. Only in the Carters' version the number of those who drowned was reduced from sixteen hundred to six hundred. While Mize's dreaming watchman is back, the Carters' text, like Darby and Tarlton in "After the Sinking of the Titanic", refers to the drinking of Captain Smith as the reason why he let the ship go on. And the last song played by the band was "Nearer, My God, to Thee". Bob Dylan has several times acknowledged his debt to the Carter Family. He made this very explicit in an interview from 2004:

Well, you have to understand that I'm not a melodist. My songs are either based on old Protestant hymns or Carter Family songs or variations of the blues form [...]. I wrote 'Blowin' in the Wind' in 10 minutes, just put words to an old spiritual, probably something I learned from Carter Family records. That's the folk music tradition. You use what's been handed down. (Cott, 2017, p. 466-67)

Bob Dylan's song “Tempest” is no doubt influenced by the Carter Family version of "The Titanic". Still, it is a grandiose overstatement to argue that Dylan's song is “based upon 'The Titanic" (Selnes, 2016, p. 590). This is the first verse of The Carter Family song:

3 For the Carter Family lyrics, see https://genius.com/The-carter-family-the-titanic-lyrics. The song can also be heard on youtube: https://www.youtube.com/watch?v=luDKIJo5y-U. 
The pale moon rose in its glory

She's drifting from golden west

She told a sad, sad story

Six hundred had gone to rest

In Bob Dylan's songwriting the exploration of an existing song often becomes the basis for the development of another song (Negus, 2008, p. 93). The first line of "Scarlet Town" is identical with the first line of the folk ballad "Barbara Allen”. This folk philosophy is central to Dylan's creative process, and "Tempest" is a good example of Dylan using "what has been handed down". As in many other songs, Dylan in "Tempest" is preserving elements from the past, while at the same time appropriating them in a creative way (Negus, 2008, p. 85). This is the first verse of Dylan's song:

The pale moon rose in its glory

Out on the western town

She told a sad, sad story

Of the great ship that went down

Dylan uses "The Titanic" as a point of departure for his own song, but there are many significant differences between the song from 1952 and the one from 2012. The first and the third lines of the first verse are identical. On the other hand, Dylan's moon does not rise on the ocean but "out on the Western town". Another significant difference between the two songs is Dylan's pessimistic and the Carters' optimistic ending (almost identical with Mize's text):

The little children were crying

Poor mama she's gone to stay

Oh surely they'll invent something

To raise the Titanic some day

This positive note, reflecting belief in human progress, is totally absent from "Tempest", where the sinking of the Titanic is interpreted as an act of or metaphor for divine judgment. The fact that he took the melody from the Carter Family recording still makes it possible to hear some of the old song in the new one. However, the discontinuity is much more striking than the continuity. According to Dylan himself the continuity 
connecting "Tempest" with the Titanic song tradition is best expressed by the term "imagination":

All the old country singers, country blues, hillbilly singers, rock \& roll singers, what they all had in common was a powerful imagination. And I have that, too. It's not that unusual for me to write a song about the Titanic tragedy any more that it was for Leadbelly. ${ }^{4}$ It might be unusual to write such a long ballad about it, but not necessarily about the disaster itself. (Gilmore, 2012b, p. 50)

What Dylan has in common with others who wrote about the Titanic disaster is a powerful imagination. "Tempest" is the result of Dylan using imagination to create his own version of an event that generated a tremendous creativity among musicians and songwriters from different traditions.

\section{An apocalyptic text}

In his biography No Direction Home Robert Shelton writes that in "Desolation Row" Dylan "articulates the rock visions of contemporary apocalypse". In Shelton's opinion this song is one of the strongest expressions of apocalypse to have seen the light of day in the last hundred years or so, able to stand alongside Eliot's "The Waste Land" and Ginsberg's "Howl” (Shelton, 2010, p. 198). Saul Wilentz thinks that with its repeated images of drowning at sea, and in references to the Titanic, Shakespeare's Ophelia, Nero's Neptune, Noah's ark and the great rainbow, the song almost certainly echoes Eliot's repeated invocations of death by water in "The Waste Land". Crammed aboard the damned Titanic, the people in "Desolation Row" are oblivious to what is happening (Wilentz, 2010, p. 82-83). As Michael Gray has pointed out, in "Desolation Row" the imminent disasters are past and present as well as future. The most striking evocation of impending catastrophe is achieved very simply, in the arresting line "The Titanic sails at dawn":

4 Leadbelly began to play his song "Titanic" in 1912, and he recorded it in 1948. When he wrote the song he drew on news reports, other folk songs, and an African-American perspective on the event (Wells, 2009, p. 102-103) In the song he made a sharp comment about race relations. For Leadbelly there was a sense of irony in the disaster, because the Titanic had refused to carry black passengers. His song attributes the following quote to the captain: "We don't haul no coal." 
Praise be to Nero's Neptune

The Titanic sails at dawn

Everybody's shouting

Which side are you on?

The verses pile up and pile up and there is no suggestion that the crescendo will ever be curtailed. Although the climactic catastrophe never comes, Dylan's intimation of disaster builds up towards one. Gray argues that Dylan in "Desolation Row" takes the Titanic to represent contemporary America. The Titanic was the ship of the future, the proof of man's civilization and progress, the unsinkable ship, which, on her maiden voyage, sank (Gray, 2000, p. 136-37).

In Thomas O. Beebee's recent interpretation "Desolation Row" is Dylan's answer to the American millennial project. He argues that Dylan is using the term "desolation" in the biblical sense, "for numerous Old Testament prophets use the word to describe the Lord's vengeance, which will make Jerusalem a 'desolation"” (Beebee, 2009, p. 161). "Desolation Row" is far from exceptional in combining water and apocalypse. John Herdman has suggested that the rather odd first line of "The Mighty Quinn”, "Everybody's building the big ships and the boats", also refers to the fate of the Titanic (Herdman, 1981, p. 95).

In "Tempest" Dylan no longer hints at the catastrophe, but makes it happen. Both "Desolation Row" and "Tempest" are apocalyptic texts. In both songs many different characters from myth and history appear, like Ezra Pound and T.S Eliot struggling for command of the ship and fighting in the captain's tower in the former, and Calvin and Blake gambling in the dark in the latter. David Yaffe connects "Desolation Row" with "High Water (For Charley Patton)": they are both "apocalyptic pronouncements" (Yaffe, 2011, p. 115):

The point of the anaphora - "High Water Everywhere" - is that all culture, from the blues icons, the snippets of English balladry, and scientific and humanistic modernity, is all going down in the flood. Dylan has been down this lonesome road before. "Desolation Row" [...] also takes culture from high and low, [...] and all join in the downward descent. (Yaffe, 2011, p. 118) 
Like other texts in the same genre "Tempest" uses apocalyptic themes and language. Apocalyptic texts are focused on a period of time in the future when God will intervene to judge the world, when God will break into this world of time and space to bring the entire system to a final reckoning (Mounce, 1998, p. 3). There are two apocalyptic books in the Bible, the Book of Daniel and the Book of Revelation, and one of them is explicitly mentioned on "Tempest". In the 2012 Rolling Stone interview Mikal Gilmore asked Dylan: "Clearly, the language of the Bible still provides imagery in your songs"? Dylan answered: "Of course, what else could there be? I believe in the Book of Revelation. I believe in disclosure, you know?" (Gilmore, 2012b, p. 51). This echoes what Dylan told Rolling Stone in 1984: "I believe in the Book of Revelation" (Cott, 2017, p. 306).

In the Rolling Stone interview Mikal Gilmore noted that in some Titanic songs, there were those who saw the event as a judgment on modern times, on humankind for assuming that the Titanic could be unsinkable. He then asked Dylan if there is something of that in his song. To this Dylan answered: “No. no, I try to stay away from all that stuff. I don't imply any of it. I'm not interested in it. I'm just interested in showing you what happened, on the level that it happened on. That's all. The meaning of it is beyond me" (Gilmore, 2012b, p. 50). Partly, Dylan is showing us what happened: "The seas [were] sharp and clear", chandeliers were swaying, an orchestra was playing, the smokestack was leaning sideways, there were "icy waters" and the ship was going under. The expression "the ship's bow split apart" (verse fourteen) might even be a reference to the iceberg hitting the ship.

In spite of what Dylan maintains, most of the incidents or people mentioned have nothing to do with the Titanic's maiden, and final, voyage. The ship was well supplied with specialist lookouts or watchmen, and they were not asleep. Since the night was moonless and the conditions were very calm it was difficult to see far ahead. With the exception of Mr. Astor and the captain none of the passengers Dylan mentions were on board the actual Titanic. Instead of the iceberg there is a whirlwind and "sky spinning all around". In other words, Dylan is clearly not just interested in showing the listener what actually happened, and the song's main concern is not the sinking of the ship in time and space. 


\section{Meteorological phenomenon and powerful image}

A tempest is a violent storm. The origin of the word is from Latin tempestas, "weather", "storm", and from tempus, "time”, "season". Dylan has never before used the word tempest in his lyrics, but he has several times utilized storm imagery to convey a sense of spiritual upheaval. It is a striking feature of many of his most famous early songs, like "A Hard Rain's A-Gonna Fall”, “The Times They Are A-Changing” and "Chimes of Freedom". Jenny Ledeen points out that references to a great storm, heavy rain and flooding in Dylan's lyrics become powerful images of impending apocalypse:

Early in 1963 Dylan responded to the idea that he was a prophet in a song, with the words, “I know I ain't no prophet/And I ain't no prophet's son!". But from time to time he would write another song that hinted about Judgment Day the way 'Blowin' in the Wind' did - by making reference to the wind, the rain, or other effects of a storm, including especially a deluge like the great flood described in the Bible. (Ledeen, 1995, p. 11)

"All Along the Watchtower" closes with the howling of the wind, "which, like the wrath of a vengeful God, seems to strip the world bare" (Burns, 2008, p. 57). The title "Tempest" suggests that this song belongs to the same category as the songs just mentioned.

Protestant hymns often provide important source material in Dylan's songs. In the song "In the sun and moon and stars" the English bishop Reginald Heber (1783-1826) vividly described the apocalypse, using the word "tempest":

Soon shall ocean's hoary deep,

Tossed with stronger tempests, rise;

Darker storms the mountains sweep,

Redder lightning rend the skies

In the Bible the word tempest has two connotations, and they are not mutually exclusive. The biblical tempest can refer to a natural phenomenon. The story of Jonah begins with a divine intervention in the form of a tempest, resulting in a shipwreck: "But the Lord sent out a great wind 58 
into the sea, and there was a mighty tempest in the sea, so that the ship was like to be broken" (Jonah 1:4, KJV).

It can also refer to a strong wind associated with God, a phenomenon accompanying the manifestation of divine presence. When God manifests himself in a theophany it can be very tempestuous round about him, especially when he appears as the judge (Isa. 30:30). In the gospel accounts, in the KJV, the word "tempest" appears only once, in a text combining a tempest, a ship and a sleeping watchman: "And, behold, there arose a great tempest in the sea, insomuch that the ship was covered with waves: but he [Jesus] was asleep" (Matt. 8:24).

\section{The music and the voice}

In Dylan's songs the music always plays an important role in the construction of meaning. The meaning of a song is never purely in the lyrics, and it cannot be analyzed separately from the music. This issue is something Bob Dylan has addressed several times:

A lot of times people will take the music out of my lyrics and just read them as lyrics. That's not really fair because the music and the lyrics I've always felt are pretty closely wrapped up. You can't separate one from the other that simply. A lot of time the meaning is more in the way a line is sung, and not just in the line. (Cott, 2006, p. 328)

"Tempest" is a song (and not a poem), where Dylan has taken the melody from the Mize/Carter version. It is the melody more than the lyrics of "The Titanic" that is important to Dylan: "I was just fooling with that [The Carter Family's “The Titanic”] one night. I liked the melody - I liked it a lot. 'Maybe I'm gonna appropriate this melody.' But where would I go with it"? (Gilmore, 2012a, p. 16). The melody links Dylan's song with the Carter Family, an institution in American folk and country music.

As far as the musical genre of "Tempest" is concerned, the song has been described as the "lush tones of a waltz" (Mentz, 2015, p. 162), and as "a seesawing ballad tune, a slow Irish jig" (Brown, 2014, p. 231-32) - that is, a cheerful, jaunty piece of music. The Irish connection is important, since RMS Titanic was constructed and built at the Harland \& Wolff shipyard 
in Belfast. The liveliness of the song is further expressed through David Hidalgo's fiddle, which does not sound mournful (pace Beviglia, 2013, p. 37), but lively.

Another important matter is the vocal expression and presentation of the song. Frances Downing Hunter describes Dylan's voice on “Tempest” as a croak: "I try to see the croak as a device, as a voice that he has decided to use to emphasize the ravages, not only of time but what has been done to our country - the corporate greed [...]. He sees where the ship of state is headed" (Bream, 2015, p. 215). Richard Elliott points out that Dylan's singing voice on "Tempest" takes on something of the qualities of the scene it depicts:

The weathered vocal ploughs an almost straight course through the sea of instrumentation: 'almost' because it is the occasional surging and pitching of the voice in relation to the predominant gentle sway of the music that provides the emotional contact points. Or, because voice and music blend so well, we might think of Dylan's voice as the sea - constant but unpredictable - into which we as listeners are invited to submerge ourselves [...] Dylan's voice can claim the sea's victory rather than the ship's defeat: it abides. (Elliott, 2015, p. 179-180)

In an interesting article Christophe Lebold seeks to examine the specific literary pleasures experienced by listeners of Bob Dylan's songs. He argues that the way Dylan performs the lyrics shows a fascination for a rhythmical language that is inherently literary. This is certainly true of “Tempest”. Lebold continues:

His so-called 'bad' voice is a sonic echo of the recurring theme of human imperfection and the motif of the fall of man (into sin, old age, or wretchedness). Dylan's more recent broken voice enables him to present a worldview at the sonic surface of the songs - this voice carries us across the landscape of a broken, fallen world. The anatomy of a broken world in 'Everything is Broken' is but an example of how the thematic concern with all things broken is grounded in a concrete sonic reality. Again, the broken timbre is but a sign, an index of an ontological brokenness. (Lebold, 2007, p. 64-65)

Lebold wrote these lines several years before Bob Dylan released Tempest. However, every word of his approach to Dylan's voice is transferable to 
Dylan's performance of "Tempest". His voice, which some would say is croaking, is extremely well suited to express the tragedy at the heart of the song. In "Tempest" the narrative transcends the actual tragedy, and this is reflected in the voice of the singer. He is not performing a lament or an elegy. The voice is broken, but from this brokenness another feeling emerges, one of confidence, hope, even joy.

\section{The identity of the dreaming watchman}

A central figure in the texts by Seth Newton Mize and the Carter Family is the watchman. An important key to understanding both "The Titanic" and "Tempest" is the identity and role of this figure. Dylan has retained, and further developed, this persona from the Carter Family song. The second verse of the Carter Family's "The Titanic" describes a dreaming watchman:

The watchman was a dreaming

Yes dreaming a sad, sad dream

He dreamed the Titanic was sinking

Out on the deep blue sea

The identity of this watchman becomes clear in the next verse: "He rose and called the rich man, and told him to come to life." The watchman also "tried to save the rich man's baby and his darling wife". The rich man is probably John Jacob Astor IV (1864-1912), to whom Dylan devotes a verse (verse twenty-four) in “Tempest”. In the Carters' song, the watchman clearly is on board the ship, he is on the lookout for icebergs, but he has fallen asleep.

The four watchman verses in "Tempest" act as interludes to create pauses in the narrative, and they precede the musical breaks. The four verses are different, but the first line in each verse is almost identical: verses six, thirty-eight and forty-five have "The watchman he lay dreaming", while verse seventeen says “The watchman lay there dreaming”. In Dylan's text the watchman never wakes up, and he is not looking for icebergs. On the contrary, even in the last verse of the song, he is still dreaming. Dylan has transformed the watchman persona into something far more pivotal and 
suggestive compared to the role of the watchman in the Carter Family song. The first time he appears in Dylan's text is in verse six:

The watchman he lay dreaming

As the ballroom dancers twirled

He dreamed the Titanic was sinking

Into the underworld

It is significant that he dreams the ship is going into the "underworld", the realm of the dead and a mythic place. In Revelation there are two terms for the underworld. On seven occasions it is called the abyss, which is the Jewish counterpart of Hades. On four occasions it is called Hades, always paired with a reference to death. However, the author of the Book of Revelation never describes the nature of existence in those locations, or their physical features. In the Bible words like sea, waters, flood and abyss are often used complementarily, to symbolize the underworld of the dead. In verse seventeen the watchman sees the ship "dropping to her knees":

The watchman lay there dreaming

At forty-five degrees

He dreamed the Titanic was sinking

Dropping to her knees

This expression, like the similar "fall on one's knees" or simply "kneel", describes a praying position, or the position of someone expressing awe and humility. In the watchman's dream the sinking of the Titanic is portrayed as an act of prayer and humiliation. While the ship was "dropping to her knees", the captain is later said to be "kneeling at the wheel".

In his Nobel Lecture Dylan mentioned hearing "the deep-pitched voice of John the Revelator". "John the Revelator" is a traditional gospel blues song, performed in a call and response style. The American gospel blues musician Blind Willie Johnson (1897-1945), with his characteristic deeppitched voice, recorded it in 1930. It was later included on Harry Smith's Anthology of American Folk Music. It remains one of Johnson's most wellknown songs. The song's title refers to John, the author of the Book of Revelation. Dylan makes a connection between listening to Blind Willie Johnson, "John the Revelator", and the sinking of the Titanic: 
By listening to all the early folk artists and singing the songs yourself, you pick up the vernacular. You internalize it. You sing it in the ragtime blues, work songs, Georgia sea shanties, Appalachian ballads, and cowboy songs. You hear all the finer points, and you learn the details. You know what it's all about [...]. You know that Stagger Lee was a bad man and that Frankie was a good girl. You know that Washington is a bourgeois town and you've heard the deeppitched voice of John the Revelator and you saw the Titanic sink in a boggy creek. (Dylan, 2017, p. 4-5)

In 1929 Blind Willie Johnson recorded another gospel blues song, "God Moves on the Water". This Titanic song was a staple in his oeuvre, and the title probably alludes to the creation story in Gen. 1:2: "And the Spirit of God moved upon the face of the waters" (KJV). Dylan, on Modern Times, reworked Gen. 1:2 into the couplet "Spirit on the water/Darkness on the face of the deep". Like folk preachers, Johnson's words in "God Moves on the Water" paint a vivid, dramatic scene. His message is that the disaster was God's judgment on modern mammonism (Hayes, 2017, p. 183-84). In his song the watchmen fell asleep:

The guards who had been watching

Asleep for they were tired

When they heard the great excitement

Many gunshots were fired

God moves

The lyrics of Johnson's "John the Revelator" contain several references to the last book of the Bible. Beebee states that in the first verse of "A Hard Rain's A-Gonna Fall" the singer is identified as a John the Revelator, who has made a supernatural or catabatic journey and lived to tell about it. Beebee takes the hard rain to represent God's wrath, and the next three verses relate "John's" visions (Beebee, 2009, p. 159).

Several interpretations of the watchman persona are possible, and they are all closely related. My view is that the role of the watchman in "Tempest" is similar to the I-figure, the narrator of "A Hard Rain's A-Gonna Fall"; they are both modern day "John the Revelator" personas. Just as John in the Book of Revelation received visions from a source outside of 
himself, so the apocalyptic drama is revealed to the watchman by means of a dream or a vision.

This watchman is not a crew member, he is not a figure in the plot, he is situated outside of the story. There are similarities between this character and the narrators in "Highlands" and "Cross the Green Mountain", who both fall asleep or into a dream world, before the narrative begins. "Cross the Green Mountain" opens with the narrator dreaming a monstrous dream, in which something comes up out of the sea. Like the "dreamer" in this visionary song the watchman in "Tempest" is also a character from another world. It is significant that he is not merely sleeping but dreaming, a condition halfway between sleep and being awake. In verse thirty-eight the watchman is "trying" to tell someone, but the warning seems to go unheeded:

The watchman he lay dreaming

The damage had been done

He dreamed the Titanic was sinking

And he tried to tell someone

Another possible interpretation is to view the watchman as a figure for the artist; he is to be identified with Dylan himself. He is not only a dreamer, but also a messenger or a prophet in the sense that he tries to give a warning of the impending disaster. "Tempest" is thus similar to other Dylan songs, not only because of its content, but because Dylan here as elsewhere takes on the role of a prophet. Dylan's use of the term "watchman" also recalls "All Along the Watchtower", another song with apocalyptic themes and content. According to the last verse of "Tempest" the watchman dreamt, not only of the Titanic, but "of all things that can be":

The watchman he lay dreaming

Of all things that can be

He dreamed the Titanic was sinking

Into the deep blue sea

Furthermore, the way Dylan uses the term watchman in "Tempest" is similar to the use of the term in the prophetic books of the Bible. A watchman is a seer or a prophet (Ezek. 3:17;33:7). God sometimes communicated 
with the watchmen in dreams and visions (Dan. 7:1). Watchmen guarded Israel against unexpected invasions (Jer. 6:17), and sounded alerts to warn people of impending danger (Ezek. 33:6).

\section{The first part (verses 1 to 6): "'Twas the fourteen day of April"}

In the first verse Dylan has copied the line "She told a sad, sad story" from the Carter Family song. It is this female storyteller who opens "Tempest". In other words, the dreams and visions of the watchman are narrated by a female. Who is "she"? In the original Mize text "she" is the antecedent of the moon. This is also the case in "Tempest". The she-figure is only mentioned in this line, and except for being the narrator "she" does not appear elsewhere in the song. However, being the narrator, "she" plays an important role, and in some Dylan-songs the moon is the muse: "The heroine of Dylan's song 'Isis' is a moon goddess, and the main thrust of Robert Graves' book The White Goddess is that the moon goddess inspires poetry endowed with a magical quality" (Gray, 200o, p. 490). Dylan read Graves' book and met him in 1963 in London. Graves made Dylan aware of the role of the moon as muse, and in "Tempest" it can be argued that Dylan acts as an instrument for a higher power, the moon-goddess, who is telling the sad story of the great ship that went down (Holmgren, 2016, p. 23-24).

Initially one might wonder at the narrator's concern with the precise date (“"Twas the fourteen day of April”), in a song which has little regard for historical accuracy. However, the line serves to draw attention to the contrast between a temporal, as distinct from an eternal, perspective. This dualistic view of time is an important characteristic of apocalyptic literature (McGinn, 1984, p. 11). The eternal perspective is made explicit in the expressions "a golden age", "the promised hour", "eternal home" and "underworld":

'Twas the fourteen day of April

Over the waves she rode

Sailing into tomorrow

To a golden age foretold 
The passengers' destination is "a golden age foretold", an expression carrying several different meanings. It can denote a better existence in America, a country which, for many of those on board the Titanic, represents an opportunity for a better life. The golden age can also be a reference to Greek myth, where the history of humankind takes the form of four ages, each represented by a metal. The first is the golden age, a period characterized by peace, harmony, stability and prosperity. Hesiod gives the following description in Works and Days: "They lived like gods, with carefree heart, remote from toil and misery. Wretched old age did not affect them either, but with hands and feet ever unchanged they enjoyed themselves in feasting, beyond all ills, and they died as overcome by sleep. All good things were theirs" (Hesiod, 1988, p. 40). Lastly, the golden age can refer to a passage in Revelation, describing a future life in the new Jerusalem, a city made of gold (Rev. 21:18). On his debut album Dylan recorded the traditional gospel song "Gospel Plow", with the following lines:

Well I've never been to heaven

But I've been told streets up there

Are lined with gold

He later developed the ideas of these lines into his own song "City of Gold", originally written in 1980, but not officially released until Trouble No More (The Bootleg Series, vol. 13) came out in 2017. Later, in "Tempest", the golden age to come is contrasted with the "gilded age of Titanic". The expression "gilded age" is often used to describe a period in American history: the era of rapid industrialization and wealth creation that began in the 1870 s and ended with the introduction of income taxes in 1913 and the outbreak of World War I the following year. The Titanic "represented the sunset of the Gilded Age", and the ship's First Class Grand Staircase was the epitome of the opulent naval architecture of the time (Brewster, 2012, p. 2). Verse thirty-two specifies that some people drowned aboard, in glorious surroundings, upon a staircase made of "brass and polished gold".

Another sense of time arises from the expression "the promised hour was near". This expression serves a contrasting purpose, since none of the passengers, noticeably not even the bishop, seem to have been prepared for the nearness of it. There is, in other words, a strong element of 
surprise in the text. "The promised hour" often implies a sense of hope. Here it denotes the opposite: something completely unexpected and more catastrophic than anyone could possibly imagine. This expression does not occur in the Bible, but it is used to describe the greatest apocalyptic event of all, the second coming of Christ, in the Protestant hymn "See the Ransomed Millions Stand":

Hasten Lord the promised hour

Come in glory and in power

Still Thy foes are unsubdued

Nature sighs to be renewed

In "Tempest" we find ballroom dancers alight and carefree, as the ship is about to go down. In verse eight the character Leo is introduced for the first time. Cupid, the god of desire, erotic love, attraction and affection, strikes his bosom. A person shot by Cupid's arrow is filled with uncontrollable desire. "Leo" immediately falls into a woman's lap.

In the beginning of "Tempest" Dylan describes an unsuspecting group of people, carrying on with ordinary and "normal" activities. When the ship began to sink they refused to believe what was happening, and the orchestra was not playing "Nearer, My God, to Thee":

The chandeliers were swaying

From the balustrades above

The orchestra was playing

Songs of faded love

Historians still discuss what was the last song played by the eight-man orchestra before the ship went down. However, the evidence for "Nearer, My God, to Thee" being the band's final song seems overwhelming (Turner, 2011, p. 152). This poignant moment is "remembered" in many Titanic songs. In Dylan's song "Caribbean Wind" the narrator reports that outside his window the "street band [was] playing 'Nearer, My God, to Thee". There the occurrence of the phrase "Nearer, My God, to Thee" can be taken as an omen of imminent death (Gray, 2000, p. 459). In "Tempest" there is no such omen. In spite of swaying chandeliers the orchestra continued to play songs of faded love. 
In the first part of "Tempest" there is no storm or tempest. On the contrary, the seas were "sharp and clear", suggesting both danger and safety, and the "lights were holding steady". Twenty minutes before midnight on April 14th, 1912, the seas in the north Atlantic were almost unnaturally quiet, and the air was absolutely calm. The depiction of the doomed ship in the first part of the song is reminiscent of Matt. 24:37-39, where Jesus stated that the final days would be as the days of Noah. "In those days before the flood" (Matt. 24:38) the people were oblivious to all else than their own pleasurable living. They did not know the imminent danger until the flood came and swept them away. Verse thirty-eight, where the watchman "tried to tell someone", sounds like an echo of a line from in "In the Summertime" (Shot of Love, 1981): "Then came the warning that was before the flood". This situation is similar to the one in "Tempest", people living everyday and ordinary lives, a large ship, endless water, and impending doom.

\section{The second part (verses 7 to 17): "The veil was torn asunder"}

In this sequence the listener gets to know "Leo", who is carrying his sketchbook. This is a reference to Leonardo DiCaprio’s character Jack Dawson, from the tremendously successful movie Titanic. There are other explicit connections between Dylan and the James Cameron movie. James Cameron quotes Dylan, and Dylan (later) quotes Cameron. Early in the movie "Jack" says, "When you got nothing, you got nothing to lose", a line taken directly from "Like a Rolling Stone". The line, as it is used in the movie, stresses the idea of starting from zero and taking a chance on life. Later "Jack" states: "I'm just a tumbleweed, blowin' in the wind."

However, Dylan's "Leo" is not necessarily identical with James Cameron's Jack, and in "Tempest" there is no Rose or Kate (Winslet), only a woman called Cleo. Anne Margaret Daniel sees "Leo" and "Cleo" as resonant references to people in the past: "two people famous for being in boats. After all, Cleo has that barge, in which she makes her triumphal entrance for Anthony in Anthony and Cleopatra, one of the most famous, doomed, spectacular scenes in all of Shakespeare" (Daniel, 2017, p. 69, 
also Mentz, 2015, p. 166). In my view this is an improbable reading, since Cleo plays a minor role in Dylan's story. She is in no way a significant character, in verse thirty-three Leo says to her: "I think I'm going mad", to which there is no response from Cleo.

My suggestion is that Cleo is Leo's alter ego, she is the feminine side of his psyche. The name "Cleo" embodies "Leo", suggesting that although they are two people they are, at the same time, one and the same person. That Leo and Cleo are identical is reinforced by the idea of Cupid striking Leo's "bosom". The word "bosom" is normally applied to a woman rather than a man, and implies femininity. Furthermore, a search for another self, twin, muse or Madonna, has turned out to be a strikingly insistent lifelong quest for Dylan (Tillinghast, 1987, p. 173). Before the listener gets to know more about Leo, "apocalypse literally crashes in on the scene" (Hand Jones, 2013, p. 200):

\section{Smokestack leaning sideways \\ Heavy feet began to pound \\ He walked into the whirlwind \\ Sky spinning all around}

When the whirlwind hits the ship with destructive power the result is flickering lights, floating dead bodies, exploding engines, and "passengers flying backward, forward, far and fast". This disaster involves not only the Titanic or the microcosm, the whole universe or cosmic order is threatened.

There is a marked contrast in the song between up and down, "yonder" and "under". The emphasis on the latter includes phrases like "the great ship went down", "lights down in the hallway", the pleonastic "descending down the stairs", "they lowered down the lifeboats", "blood pouring down his arm" and "the needle pointing downward". By contrast the only mentions of "up" are in the bishop's turning his eyes "up" to heaven and "the roll was called up yonder":

The ship was going under

The universe opened wide

The roll was called up yonder

The angels turned aside 
In Revelation the angels surround God and his throne. "The angels turned aside" implies that they withdrew from this position, so that a revelation of God could take place. The third line of verse twelve refers to the title of a well-known Protestant hymn, "When the Roll Is Called Up Yonder", written by James Milton Black in 1893 (Sanville, 1943, p. 84-85).5 According to Black "The roll" is a reference to the Book of Life, which is mentioned several times in Revelation:

When the trumpet of the Lord shall sound, and time shall be no more

And the morning breaks, eternal, bright and fair

When the saved of earth shall gather on the other shore

And the roll is called up yonder I'll be there

The motif of a Book of Life, in which the names of the saved are written, occurs in Rev. 3:5; 13:8; 17:8 and 20:12, and once in the epistles of St. Paul (Phil. 4:3). On the one hand Rev. 17:8 seems to express a predestinarian view, because it divides humanity into two groups: those whose names have been inscribed in the Book of Life since the creation of the world, and those whose names have not. On the other hand Rev. 3:5 mentions the possibility of having one's name blotted out from the Book. This suggests that fidelity to God rather than any kind of predestination is the reason for having one's name inscribed in the "roll".

The line "The veil was torn asunder" in verse sixteen is another reference to an apocalyptic motif from the New Testament.

The veil was torn asunder

'Tween the hours of twelve and one

No change, no sudden wonder

Could undo what had been done

"The veil" probably refers to the curtain that separated the Holy of Holies from the rest of the Jewish temple. The curtains of the temple restricted access to the presence of God. The gospel of Matthew places this event in a distinctively apocalyptic context. The tearing of the veil takes place

5 For the story behind Black's song, see "James Milton Black Wanted His Name on God's Roll": https://www.christianity.com/church/church-history/timeline/1801-190o/james-milton-blackwanted- his-name-on-gods-roll-11630502.html 
between the death of Christ and several explicit apocalyptic events like the splitting of rocks, opening of tombs and raising of holy ones (Matt. 27:51).

The tearing of the veil happened "between the hours of twelve and one". It was 11:45 p.m. when the Titanic grazed along the iceberg that would send it to its ocean bed. The period between midnight and $1 \mathrm{a} . \mathrm{m}$. was very dramatic and chaotic. At 2:20 a.m. the forward deck dipped under water, and the sea poured in through open hatches and grates. After a short while the ship broke in two and sank.

In this part of the song the bow of the ship splits apart, the engines explode, and the ship is going under. Why does this catastrophe take place? The forces of nature involved are a whirlwind, and sky spinning all around, but there is no reference to an iceberg. This ship is no longer the Titanic, and instead of describing what actually happened on the fourteenth day of April another story is unfolded. This is a narrative referring to several apocalyptic events from the Bible. The whirlwind is important. It is synonymous with the title of the song, and it is a manifestation of the divine presence: "You will be visited by the Lord of hosts [...] with whirlwind and tempest" (Isa. 29:6). The great disaster is interpreted as a theophany: the angels turned aside, so that the presence of God could be made manifest. The tearing of the veil from "up" to "down" implies divine action, but also a democratization of the divine presence. It is no longer hidden behind a veil, but available to all.

\section{The third part (verses 18 to 38 ): "He tried to save all"}

This long sequence is a good example of how Dylan has "adapted the montage writing predilection for gathering multifarious references from disparate timeframes and sources, and applying them to the disciplined telling of a prolonged story" (Hodgers, 2017, p. 113). A number of different persons make their appearance: Wellington, Calvin, Blake and Wilson, Davey the brothel keeper, Jim Dandy, a bishop, and for the second time, Leo. Davey the brothel-keeper (verse twenty-nine) is a character Dylan has appropriated from the Roman poet Juvenal. In his

Satires, Volume 6, he wrote: "[Too soon] the brothel keeper dismissed 
his girls" (Juvenal, 1998, p. 38). The line "Nameless here forever more" in verse thirty-seven is identical with the last line in the second stanza of Edgar Allan Poe's poem "The Raven”, which, by the way, includes the word "tempest" twice (Poe, 2016, p. 3).

"Jim Dandy" is the name of a song recorded by LaVern Baker in 1956. The song is about a man, Jim Dandy, who rescues women from improbable or impossible predicaments. According to verse thirty-one Jim Dandy found peace when he saw the starlight shining. This is probably a reference to the wise men from the East, who had seen "his star at its rising" (Matt. 2:1-2):

\section{He saw the starlight shining \\ Streaming from the East \\ Death was on the rampage \\ But his heart was now at peace}

This is similar to a line from "No Time to Think", where a girl travels on a bridge that goes to Babylon, but then she (the "you" of the text) sees the "starlight in the East, and you're finally released". The redemptive element in "Desolation Row" is Noah's great rainbow, and in "A Hard Rain's A-Gonna Fall" a glimpse of hope shines through in the sentence "She gave me a rainbow". The possibility of redemption in "Tempest" is first hinted at when Jim Dandy gave his place on a lifeboat to a little crippled child. He gave away his own chance to be rescued so that another person could be rescued in his place.

Is Wellington identical with Arthur Wellesley (1769-1852), known as the 1st Duke of Wellington, who is most famous for his victory against Napoleon at the battle of Waterloo in 1815 ? His response to the disaster is to "strap on both his pistols" and wonder how long he could "hold out", as if he were under siege. As a passenger on a sinking ship, his behavior is strange and ludicrous. In a way this matches the response of the bishop. Whereas the bishop thinks irrelevantly of hunger, Wellington thinks equally irrelevantly of protecting himself against aggressors. He discovers that "the passageway was narrow", but his response on seeing this was merely to notice people's misery rather than go down the passageway to see what help he could provide. The phrase is reminiscent both of "Long and Narrow Way", 
and the New Testament warning "narrow is the road that leads to salvation" (Matt. 7:14). The broad road, by contrast, is leading to destruction. In not taking the narrow way, Wellington seems to have missed the chance to be saved, both in the temporal and in the eternal sense.

The bishop is aware of his obligations but seems to do little about them. In the gospel of Matthew Jesus saw the great crowd of five thousand. Then he said to his disciples: "You give them something to eat" (Matt. 14:16). The bishop turns his eyes away from the people and up to the heavens. His comment to God, "the poor are yours to feed", is a way of refusing responsibility. In the dramatic situation on board the ship the bishop's supplication to heaven is not an expression of faith or compassion. Although there were plenty of poor people on board, hunger was hardly their present concern. The bishop should in any case be serving anyone who needed help, whether rich or poor.

The inadequate attitudes of Wellington and the bishop contrast with that of Leo, who clearly is an important figure to Dylan: "Yeah, Leo. I don't think the song would be the same without him. Or the movie" (Gilmore, 2012a, p. 16). In the movie Jack Dawson is a sort of classless "superman", and Rose's romance with him is a redemption tale, coupling a woman in distress with a somewhat superhuman being who exactly fulfils her needs (Koldau, 2012, p. 188). Near the end of the movie old Rose says of Jack: "There was a man called Jack Dawson, and he saved me in every way that a human can be saved" (Cameron, 1998a, p. 149). He saved her in two ways at least: from suicide in the first part of the movie, and in the last part he gave up his life so that she could live on. Just as in the movie, Dylan's Leo tries to save others before eventually "saving" himself:

He tried to block the doorway

To save all those from harm

Blood from an open wound

Pouring down his arm

In "Tempest" Leo is presented as a Christ-like character whose efforts for others are at the expense of his own blood. This makes his contrast with the bishop all the more ironic. Whereas the bishop merely refers to "the poor", Leo's arm is actually pouring blood. This also puts him in 
contrast with the host-persona in verse thirty-six, who likewise is pouring, but merely brandy. According to the Gospel of John one of the soldiers pierced Jesus' side with a spear after he had died, but while he still hung on the cross: "And at once blood and water came out" (John 19:34). A very common motif in Christian iconography is Jesus, depicted hanging on the cross, with blood pouring out from an open wound.

It is significant too that Leo has "an open wound", associating it with the universe which had "opened wide" to reveal God (Weir, 2016). Leo thus represents the most explicit possibility of redemption; he is trying to save the doomed people with his own life. In Yonder Comes Sin A. T. Bradford contends that the blood "that Dylan is singing of as 'paying for him' [in "Pay in Blood"], is surely not the blood of any mortal man, but of Christ" (Bradford, 2015, p. 576). Similarly Andrew Muir thinks "the phrase 'pay in blood' itself [...] has to put one in mind of Jesus paying for the sins of humankind with his blood. It is inconceivable that the connotation would not occur to Dylan" (Muir, 2019, p. 313). That makes an interesting connection between "Pay in Blood" and "Tempest".

Wellington discovered that "there was blackness in the air". In the Bible blackness or darkness is a common metaphor for the judgment that will come on the day of the Lord (Joel 2:2; 31, Zeph. 1:15). According to the gospels darkness came over the whole land in the last hours before Jesus died (Matt. 27:45). In this situation alarm bells were ringing, just like in "Ring Them Bells", another Dylan song with apocalyptic motifs. In "Ring Them Bells" there is no dreaming watchman, but a shepherd who is asleep. The bells in "Tempest" were ringing to hold back "the swelling tide". This expression occurs in an apocalyptic context in the Protestant hymn "My Savior First of All":

When my lifework is ended, and I cross the swelling tide

When the bright and glorious morning I shall see

I shall know my Redeemer when I reach the other side

And his smile will be the first to welcome me

The idea of predestination is present in "Tempest" by way of a strong feeling of pointlessness and futility (Weir, 2016). Alarm bells ring "to keep back the swelling tide", Wellington straps on his pistols, some passengers 
cling to each other, others jump into icy water, the brothel keeper dismisses his girls and in the end people wait at the landing. All of these things are futile, since "no change, no sudden wonder, could undo what had been done", because "all things had run their course". The phrase "run their course" suggests that history develops according to a divine plan, before it comes to a preordained ending. The notion of predestination is also introduced by the appearance of a person called Calvin:

Calvin, Blake and Wilson

Gambled in the dark

Not one of them would ever live to

Tell the tale of disembark

This is probably a reference to the sixteenth century protestant theologian John Calvin (1509-1564). He is well-known for his theory of double predestination: the view that God has actively chosen some people for damnation and destruction, others for salvation and eternal life. Together with Blake and Wilson, Calvin "gambled in the dark". Gambling is an event with an uncertain outcome, there is a strong element of chance involved. Chance is the opposite of preordained destiny. By bringing Calvin into his text, Dylan also introduces the notion of predestination. Since Calvin is "gambling in the dark" it is important not to draw hasty conclusions as far as the theology behind "Tempest" is concerned. After all, "there is no understanding on the judgment of God's hand".

Blake is probably William Blake (1757-1827), who saw his words as being a continuation of the words of John, the disciple of Jesus, who, when he was exiled on the island of Patmos, wrote the Book of Revelation. Blake not only thought of himself as a prophet, but democratized prophecy, for "Every honest man is a prophet" (Erdman, 2008, p. 617). In Blake's interpretation the Book of Revelation laid bare the realities of history more than it offered a map of the end of the world: "It sets forth the reality of what is going on in the world and the pervasiveness of human self-deception, and summons its readers and hearers to change their outlook and practice" (Rowland, 2016, p. 13). Blake was thoroughly opposed to the idea of predestination.

Heinrich Detering thinks that Calvin and Wilson are the American presidents Calvin Coolidge and Woodrow Wilson (Detering, 2016, p. 93). 
Wilson was president from 1913 to 1921, and Coolidge from 1923 to 1929. When the Titanic sank William H. Taft was president. It is possible that "Wilson" is Woodrow Wilson, who was a Presbyterian and held strong Calvinist beliefs (Hankins, 2016). That would make an interesting combination of theologian, poet and politician, all three of them gambling in a situation where the outcome was most uncertain.

The violent events alluded to in verse twenty-six are either the murder of Abel by Cain or the end time persecution of the believers as described in the gospels:

Brother rose up against brother

In every circumstance

They fought and slaughtered each other

In a deadly dance

In "Desolation Row" Cain and Abel are the biblical types for human quarrelling and self-destruction. Jesus predicted that the opposition the apostles will face in the last days will be more than merely political and social. Those who respond in faith and obedience to the gospel will face opposition from their own families: "Brother will betray brother to death, and a father his child, and children will rise against parents and have them put to death" (Mark 13:12). This tradition of the divided family became a fixture in apocalyptic expectation. It is also an integral part of the "Tempest" lyrics.

The expression "the rich man", preserved from the Carter song, is used explicitly in verse twenty-four to describe John Jacob Astor IV. He was the wealthiest person aboard the Titanic, and is well known for financing the Astoria hotel in New York. Astor is by no means unique in being rich among the passengers described as "all the lords and ladies". Later we are told that "the host was pouring brandy", again implying a lavish lifestyle, as does the presence of an orchestra (as distinct from a mere band), and ballroom dancers. What is the identity of the host in verse thirty-six?

The host was pouring brandy

He was going down slow

He stayed right 'til the end

He was the last to go 
In James Cameron's Titanic script, the word "host" is used once. In the beginning of the movie Cal, Rose's unsympathetic fiancé, says: "It is unsinkable. God himself could not sink this ship". Then the script continues: "Cal speaks with the pride of a host providing a special experience" (Cameron, 1998a, p. 33-34). Later on Jack asks Rose in Rose's suite whether they should be expecting Cal to be back soon. Rose answers: "Not as long as the cigars and brandy hold out" (Cameron, 1998a, p. 98). When the ship is sinking, Cal is the last person to get on board one of the lifeboats, thus excluding others from being rescued. If Dylan's host is Cameron's Cal, the word host is used ironically. A host is a person who invites and includes. Cal does the opposite; unlike Leo he always puts himself first. He also provides a good example of someone who is capable of fighting and slaughtering others.

Michael J. Gilmour thinks Dylan is imagining Rev. 18:11-24 as he depicts the splendors of the luxury liner (Gilmour, 2017, p. 71). He points out that in this passage Revelation condemns extreme wealth and the decadence and abuses of power that come with it. RMS Titanic was the embodiment of extravagance and excess. In "Tempest" chandeliers sway from the balustrades, and the staircase is decorated with "brass and polished gold”. According to Cameron's script John Jacob Astor was on the grand staircase when the ship went under. This is what he saw: "A Niagara of sea water thunders down into the room, blasting through the first class opulence. It is the Armageddon of elegance" (Cameron, 1998a, p. 239).

The third part of the song is similar to the second because of the continuing use of apocalyptic imagery. Because of the Leo-persona this part also offers another perspective. Why did Dylan use the name Leo, and not Jack, which is his name in Cameron's movie? My suggestion is that this is because the name Leo means "lion", a designation of Jesus in Revelation, where he is called "the Lion of Judah" (Rev. 5:5). According to verse thirty-four he tries to save all, while his blood is pouring from an open wound. The verb save is also used to characterize the actions of Jack Dawson, but he is only trying to save one person, while Leo tries to save all. Jack has no bleeding wounds, while the lines about the blood of Leo come immediately after the line "He tried [...] to save all". As in the Jesus narrative of the New Testament salvation and blood belong together in 
Dylan's Leo narrative. And as in the second part of the song a revelation of the divine also takes place in the third. However, this revelation is different, since it involves self-sacrifice and redemption.

\section{The fourth part (verses 39 to 45): "He read the Book of Revelation"}

In the last sequence of the song the captain looks at the compass, gazing into its face. The needle is pointing downward, and he knows he has lost the race. The expression "to lose the race" can have two meanings. Most probably it is a reference to the race across the Atlantic. A US inquiry board found Captain Smith responsible for the tragedy, citing his "indifference to danger", and "overconfidence and neglect" in steering the ship into an iceberg, while travelling or racing too fast for the conditions. The expression "the race" is also used several times in the New Testament as a metaphor, describing the life of a person who puts his trust in God and tries to live according to God's will: "I have fought the good fight, I have finished the race, I have kept the faith" (2 Tim. 4:7).

In this situation the captain remembers bygone years, and opens up a book that was presumably dear to him. He does not read from the gospels, but turns to the last book of the Bible. Time is short, and there is no time to study the whole Book of Revelation. His eyes fall upon a text that can bring him hope and comfort in a hopeless situation:

In the dark illumination

He remembered bygone years

He read the Book of Revelation

And he filled his cup with tears

Dylan never specifies what passage or chapter the captain was reading. Since Dylan has adapted several scenes from the movie Titanic into his song, I want to suggest that the captain is reading what was read by a Catholic priest onboard the doomed ship. In the movie there is a scene where a Catholic priest, Fr. Thomas Byles, is reading from the Bible. As the deck creeps past a 45-degree angle and the ship begins her descent into the abyss, Fr. Byles' voice can be heard above the wailing and sobbing: 
And I saw new heavens and a new earth. The former heavens and the former earth had passed away. I also saw a new Jerusalem, the holy city coming down out of heaven from God, beautiful as a bride prepared to meet her husband. I heard a loud voice from the throne ring out this is God's dwelling among men. He shall dwell with them and they shall be his people and He shall be their God who is always with them. He shall wipe away every tear from their eyes. And there will be no more death or mourning, crying out or pain, for the former world has passed away. (Cameron, 1998a, p. 134)

This text might imply that Cameron intended a Christian interpretation of the disaster, as the judgment of God on a materialist civilization. The text read by Fr. Byles also emphasizes that the primary meaning of the biblical apocalypse is not violent destruction or the end of history, but rather the transformation and redemption of the world.

"Dark illumination" is an oxymoron - that is, a mutually contradictory image. Similar expressions frequently occur in Dylan's lyrics (Bowden, 1982, p. 39). However, a suggestion has been made that the first line of verse forty-one can be punctuated like this: "In the dark: illumination". That would bring a different twist to the verse: "Lifted by spiritual illumination the Captain's cup would not be filled with tears of sorrow or tears of rage, but with tears of joy" (Stokes, 2012, p. 47). He knows that there will be a time when God wipes away every tear from his eyes.

In verse forty-two the term "the Reaper" occurs, another word Dylan has never used before. This term and the related expression "the Grim Reaper" is sometimes used to describe death as a personified force. The Reaper causes the death of the victims by coming to collect them. In the Book of Revelation it can refer to the fourth horseman in Rev. 6:1-8, whose name is "Death", and who comes to announce the Last Judgment. He is often pictured as a reaper, with a hooded skeleton bearing the huge curved scythe. A good example is Gustav Doré's painting The Fourth Horseman (1865). He wields the scythe, symbolizing the weapon of the harvester. It can also refer to Christ, who in Rev. 14:14 is given the order to begin the harvest of the earth. With a sickle in his hand he comes to harvest those who are ready to be reaped. The poem by Edgar Allan Poe "The City in the Sea" contains the lines "Where the good and the bad and the worst and the best/Have gone to their eternal rest" (Poe, 2016, p. 70). There is an echo of this in Dylan's text: 
When the Reaper's task had ended

Sixteen hundred had gone to rest

The good, the bad, the rich, the poor

The loveliest and the best

Furthermore, in this verse there is a contrast between the words "Reaper" and "rest". The idea of death as the reaper, appearing with a deadly tool, suggests violence and suffering. In this case the Reaper was very successful, reaping the great majority of those on board the ship. They tried to swim or held on to wreckage, and then froze to death or drowned in the icy water. The ones who died on that fateful night went to rest, an expression which is identical with the one in the Carter Family song. It is also a way of describing death suggesting calmness and peace, and the bottom of the ocean, or rather "the underworld" or "the eternal home", become places of rest. In the Bible death is often compared to rest, in expressions like "enter his [God's] rest" (Heb. 3:18), or "rest from one's labors" (Rev. 14:13).

Dylan himself has pointed to the role of tradition when he has responded to questions about the themes of death and destruction on Tempest: “There's plenty of death songs. You may well know, in folk music every other song deals with death. Everybody sings them. Death is a part of life. The sooner you know that, the better off you'll be. That's the only way to look at it" (Dylan, 2012b, p. 50). Death in "Tempest" comes as the result of a disaster, but this disaster also involves the notion of divine judgment:

They waited at the landing

And they tried to understand

But there is no understanding

On the judgment of God's hand

By advertising the ship as "virtually unsinkable" and adding a list of wealthy and prominent passengers, the White Star Line made many people feel the whole voyage reflected hubris, waste, and greed. The iceberg was the hand of God, teaching the rich and the mighty a lesson they would never forget. In many Titanic songs the ship became a metaphor for man's fatal pride and tower-of-babel aspirations. In another popular 
song called "The Titanic", recorded in 1924, Ernest Stoneman on the one hand stated that "It was sad when that great ship went down", while on the other hand he reflected the sentiment of many when he sang:

God with power in his hand

Showed the world it could not stand

What Stoneman and Dylan have in common is the reference to God's hand. ${ }^{6}$ In the Old Testament divine judgment is sometimes described as God turning his hand against someone (Amos 1:8). Dylan's lyrics differ from many other Titanic songs in that his main point is not to depict the great ship sinking under the weight of its own hubris. The last part of the song ends with the judgment of the divine hand, but this is beyond the confines of human reason, no explanation is possible or available.

Ian Bell maintains that Dylan's point, the repeated theological note struck throughout the whole Tempest album, is that "none of it sways an indifferent God whose purposes are not to be judged by His creation" (Bell, 2013, p. 527). However, Dylan's emphasis is not on the indifference of God, nor on "the judgment of God's hand". There is a divine presence in the world, and this presence manifests itself in different ways. Two different views of God are expressed in "Tempest"; the judgmental God who exacts punishment, and the God who redeems. God was present when the great ship went down, and what happened can be interpreted as an act of divine judgment. This echoes the fourth verse of "Cross the Green Mountain":

Along the dim Atlantic line

The ravaged land lies for miles behind

The light's coming forward and the streets are broad

All must yield to the avenging God

But by contrasting the verb "understand" with the expression "no understanding" Dylan's conclusion seems to be that not one human being (not

6 Stoneman's song was very popular, and a version by Versey and William Smith ("When That Great Ship Went Down") was included on the Harry Smith Anthology. In 1944 Woody Guthrie recorded "The Titanic", also inspired by the Stoneman song. However, neither the Smiths nor Guthrie included the verse describing the catastrophe as being the result of divine intervention. 
even Calvin) is intellectually capable of grasping God or God's dealings with humanity. Steve Mentz writes that "shipwrecks are hard to narrate. Human meaning-making systems cannot encompass oceanic chaos [...]. Shipwreck creates feeling but not understanding [...]. Listening to these lines in Bob's Jeremiah thunder growl is both ominous and oddly freeing" (Mentz, 2015, p. 165). In the fourth part of “Tempest” Dylan's theological reflection thus bears close resemblance to St. Paul's outburst in Romans 11:33: "How unsearchable are his judgments and how inscrutable his ways"!

\section{From "Tempest" to "Roll On John"}

Tempest closes with a tribute to the murdered John Lennon, which includes direct quotations from Beatles and Lennon songs ("A Day in the Life", "Come Together" and "The Ballad of John and Yoko"). Like "Tempest's" tale of the Titanic "Roll On John" is another song about tragedy and death. The hero of the song is doomed but the singer's main message is "roll on" and "shine a light". The song's refrain references the refrain of "Precious Angel": "Shine your light on me/You know I just can't make it by myself/I'm a little too blind to see":

Shine your light

Move it on

You burned so bright

Roll on, John

In "Roll On John" Dylan touches upon the theme of apocalypse by quoting from William Blake's famous poem "The Tyger". This poem shadows the coming of an Anti-Christ (Freed, 2014, p. 26). It also describes "an apocalypse - by definition a vast and inclusive event - which occurs in a cosmos knit by interpenetrating 'correspondences' uniting any one event with all others” (Nurmi, 1970, p. 201):

Tyger tyger burning bright

I pray the Lord my soul to keep

In the forests of the night

Cover him over and let him sleep 
In "Tempest" Blake is a passenger aboard the Titanic, and he is quoted verbatim on the next and last song on the album. The line "I pray the Lord my soul to keep" is not borrowed from Blake but from a traditional children's prayer which was included in one of the most used American school textbooks of the eighteenth century, The New England Primer. This distinctive intertextual approach to Blake suggests an awareness of the way in which Blake's Songs are influenced by eighteenth-century children's prayers and hymns. Luke Walker claims that Dylan's new composite version of “The Tyger" continues Blake's deliberately unsettling dual vision of God as both "Tyger" and "Lamb" (Walker, 2018, p. 11).

There is also another connection between "Tempest" and "Roll On John”. The John persona in the latter song is a reference to John Lennon, but like the Titanic in "Tempest" the John in the last song on the album transcends the man from Liverpool. Toby Thompson argues that it is no accident that "Tempest" is followed by "Roll On John", because it keeps the listener focused on Saint John of the Apocalypse (Thompson, 2012, p. 85). Both Johns were dreamers (“you might say I'm a dreamer").

"Roll On John" describes a sea journey ending with the foundering of the ship on the shore of an island. The "John" of the song is depicted as a hunted outcast or slave, in some way connected to a quarry and living in a cave on the island. According to ancient sources the John who wrote The Book of Revelation in the last years of his life was a slave working in a quarry, living in a cave: "These men were deported for life to work in the stone quarries, to sleep in the caves, and live in the confines of the island of Patmos. Among them was one John" (Brownrigg, 1971, p. 131). Thus, even "Roll On John" becomes an example of the "apocalyptic aesthetic, [... which] is perhaps the defining element of both the content and style of Dylan's songs, [...] apocalypse is Dylan's muse" (Janssen \& Whitelock, 2009, p. 101). John Winston Ono Lennon, living on the island of Manhattan, becomes John the Revelator, living on the island of Patmos.

\section{Conclusion: "The bar you have to pass"}

Dylan's “Tempest" refers to an historical event, but the point is not to throw light on what actually took place. The voyage is a representation of 
life, with the ship representing the world. The actual sinking of the Titanic is important only to provide a context for presenting issues concerning such matters as the revelation of God, predestination, redemption, the temporal as opposed to the eternal, attitudes to wealth and violence, and the final apocalypse. To do this Dylan makes use of various expressions drawn virtually verbatim from the Bible, from Protestant hymns, and from other classical and lyrical works. I regard verse forty-one, where the Captain reads from the Book of Revelation as crucial, as a key helping the listener to unlock "Tempest" as a whole. The melody and verse structure are borrowed from the Carter Family source. Dylan returns to the actual sinking in the last verse; at the end he brings the listener back to reality.

In between he uses his powerful imagination to construct and develop an apocalyptic vision or drama. Bob Dylan's apocalyptic imagination is "the deepest and most consistent imaginative preoccupation of his lyrical career" (Day, 2007, p. 97-98). This vision, with its emphasis on the destructive power of water, has been a recurring theme in Dylan's songs, from "The Times They Are A-Changing" to "High Water (For Charley Patton)". In the 2012 Rolling Stone interview Dylan said Tempest is not the album he set out to make: "I wanted to make something more religious. I just didn't have enough [religious songs]. Intentionally, specifically religious songs is what I wanted to do" (Gilmore, 2012a, p. 15). However, Dylan still had more than enough religious material to put into his songs, and the religious dimension is present on "Tempest" from the beginning and literally to the end.

Like Revelation "Tempest" expresses a dualistic view of time in which there are two distinct ages: the present one, which is temporal and evil, and the one to come, which is timeless and righteous. On "Tempest" Dylan, like the apocalyptic writers of the Bible, is pessimistic about the ability of human beings to cope with an evil world. Apocalyptic texts are also "characterized by a rigid determinism in which everything moves forward as divinely preordained [...] toward a predetermined end" (Mounce, 1998, p. 3). By naming one of the passengers Calvin, while another is called Blake, Dylan places his text in rich and diverse theological and literary traditions. Apocalypses claim to reveal the hidden meaning and outcome of history as a vision, bestowed by God upon a seer or 
watchman. The apocalyptic seer often uses a conventional literary style, adapting his message accordingly. Much of the material is drawn from common tradition and from contemporary historical events.

On "Tempest" Dylan achieves two things. First, with this song he "passes the bar" as a songwriter. In other words, he has written a song using elements from the Titanic song tradition, while at the same time transcending this tradition. In 1959 American folk singer Almeda Riddle (1898-1986) recorded "The Titanic", a song she learned in 1913 or 1914. At the heart of this song is a contrast between a sense of carelessness and confidence among the rich, and the ultimate fate and judgment that awaits all human beings (Wells, 2009, p. 103). The last verse of this song (quoted from Abrahams, 1970, p. 183) bears some resemblance to "Tempest". It is interesting because it reflects some important theological aspects of the Titanic song tradition:
Some on board this great vessel was rescued
Others were left to their fate
But 'twill all be made right at the judgment
There the crooked will be made straight
For a Savior who knew all about it
Rules on the land and the sea
He knew what to them would sure happen
He knew what their ending would be

Secondly, Dylan combines the Titanic song tradition with one of his alltime favourite themes, expressed in Tempest's "Scarlet Town" in the line "the end is near". There is in Dylan's work a strong and lasting "obsession with imminent apocalypse" (Gray, 2000, p. 258), and among his recent songs this obsession is nowhere as explicit as it is on "Tempest".

In the opening chapter of Chronicles Dylan describes his first meeting with Izzy Young, the owner of the Folklore Center in Greenwich Village. Young had a back room, which was filled with American records and a phonograph. Young let Dylan stay there, and Dylan listened to as many records as he could. According to Dylan the atmosphere and the music made a deep impression on him as a young singer: "The madly complicated modern world was something I took little interest in. It had no 
relevancy, no weight. I wasn't seduced by it. What was swinging, topical, and up to date for me was stuff like the Titanic sinking [...]" (Dylan, 2004, p. 20). No wonder then, that at the age of seventy-one, he finally recorded an album with a dramatic and disastrous event at its center that fascinated him when he was very young, long before he ever made a record.

\section{Literature}

Abrahams, R. D. (Ed.). (1970). A Singer and Her Songs: Almeda Riddle's Book of Ballads. Baton Rouge: Louisiana State University Press.

Beebee, T. O. (2009). Millennial Literatures of the Americas, 1492-2002. Oxford: Oxford University Press.

Bell, I. (2013). Time Out of Mind: The Lives of Bob Dylan. Edinburgh: Mainstream Publishing Company.

Bottrall, M. (Ed.). (1970). William Blake: Songs of Innocence and Experience. A Casebook. London: Macmillan.

Bowden, B. (1982). Performed Literature: Words and Music by Bob Dylan. Bloomington: Indiana University Press.

Bradford, A. T. (2015). As Reviewed by Bob Dylan - Yonder Comes Sin. London: Templehouse Publishing.

Bream, J. (2015). Dylan: Disc by Disc. Minneapolis: Voyageur Press.

Brewster, H. (2012). Gilded Lives, Fatal Voyage: The Titanic's First-Class Passengers and their World. London: The Robson Press.

Brown, D. (2014). Bob Dylan: American Troubadour. Lanham: Rowman \& Littlefield.

Brownrigg, R. (1971/2002). Who's Who In the NT. London: Routledge.

Burns, J. (2008). Series of Dreams: The Vision Songs of Bob Dylan.

Kirkcudbrightshire: Glen Murray Publishing.

Cameron, J. (1998a). Titanic. A Screenplay. Annotated by R. Frakes. New York: HarperCollins.

Cameron, J. (1998b). Titanic. Twentieth Century Fox and Paramount Pictures. DVD.

Carter Family 2008. “The Acme Sessions 1952/56”. Disc A. JSP Records. CD.

Cott, J. (Ed.). (2017). Bob Dylan: The Essential Interviews. New York: Simon \& Schuster.

Daniel, A. M. (2017). Tempest, Bob Dylan and the Bardic Arts in N. Goss \&

E. Hoffman (Eds.) Tearing the World Apart: Bob Dylan and the Twenty-First Century (p. 63-72 ). Jackson: University Press of Mississippi.

Darby, T., \& Tarlton, J. (2005). Atlanta, New York, Charlotte 1930-1933. JSP Records. CD C.

Day, A. (2007). Dylan's Judgment. American Studies in Scandinavia, 39, No 1, 84-101. 
Detering, H. (2016). Die Stimmen aus der Unterwelt. Bob Dylans Mysterienspiele. München: C.H.Beck.

Dylan, B. (2004). Chronicles, Volume one. London: Simon \& Schuster.

Dylan, B. (2005). Tarantula. New York: Harper Perennial.

Dylan, B. (2012). Tempest. New York: Columbia Records. CD.

Dylan, B. (2016). The Lyrics 1961 - 2012. London: Simon \& Schuster.

Dylan, B. (2017). The Nobel Lecture. New York: Simon \& Schuster.

Elliott, R. (2015). The Late Voice. Time, Age and Experience in Popular Music. London: Bloomsbury.

Erdman D. V. (Ed.). (2008). The Complete Poetry \& Prose of William Blake. Berkeley: University of California Press.

Freed, E. R. (2014). 'By Wondrous Birth': The Nativity of William Blake's 'The Tyger'. English Studies in Africa, vol. 57/2, 13-32. https://doi.org/10.1080/00138398.2014.9 63281

Gilmore, M. (2012a). Bob Dylan on His Dark New LP. Rolling Stone, August 16 (Issue $1163), 15-16$.

Gilmore, M. (2012b). Bob Dylan: The Rolling Stone Interview. Rolling Stone, September 27 (Issue 1166), 42-51, 80-81.

Gilmour, M. J. 2017. The Bible and Popular Music. In C. A. Partridge \& J. Moberg, (Eds.), The Bloomsbury Handbook of Religion and Popular Music. (p. 67-76). London: Bloomsbury.

Goss, N., \& Hoffman, E. (Eds.). (2017). Tearing the World Apart: Bob Dylan and the Twenty-First Century. Jackson: University Press of Mississippi.

Gray, M. (2000). Song \& Dance Man III: The Art of Bob Dylan. London: Continuum.

Hand Jones, C. (2013). Bob Dylan and the End of the Modern World.

Dissertation. Dallas: The University of Texas. https://search.proquest.com/ docview/1492334849?pq-origsite=gscholar.

Hankins, B. (2016). Woodrow Wilson: Ruling Elder, Spiritual President. Oxford. Oxford University Press.

Hayes, J. (2017). Hard, hard religion: Interracial Faith in the Poor South. Chapel Hill: The University of North Carolina Press.

Herdman, J. (1982). Voice Without Restraint: Bob Dylan's Lyrics and their Background. Edinburgh: Paul Harris Publishing.

Hesiod (1988). Theogony \& Works and Days. A New Translation by M. L. West. Oxford: Oxford University Press.

Hodgers, J. (2017). "Narrative in 'Love and Theft', Modern Times, and Tempest", in N. Goss \& E. Hoffman (Eds.), Tearing the World Apart: Bob Dylan and the Twenty-First Century. (p. 103-116). Jackson: University Press of Mississippi.

Holmgren, O. (2016). Bob Dylan. Stickspår. Åtta skäl varför Bob Dylan borde tildelas Nobelpriset i litteratur. Stockholm: Carlssons Bokförlag. 
Janssen, D., \& Whitelock, E. (2009). Apocalypse Jukebox: The End of the World in American Popular Music. Berkeley: Soft Skull Press.

Jurek, T. (2012). Bob Dylan. Tempest. All music Review: https://www.allmusic.com/ album/tempest-mwooo2405466

Juvenal (1998). The Sixteen Satires. Translated by Peter Green. London: Penguin Classics.

King James Version (KJV). https://www.kingjamesbibleonline.org/

Koldau, L. M. (2012). The Titanic on Film: Myth versus Truth. Jefferson, North Carolina: McFarland \& Company.

Lebold, C. (2007). A Face like a Mask and a Voice that Croaks: An Integrated Poetics of Bob Dylan's Voice, Personae, and Lyrics. Oral Tradition 22/1, 57-70.

Ledeen, J. (1995). Prophecy in the Christian Era. St. Louis: Peaceberry Press.

MacMahon, B., \& McGourty, A. with Wald, E. (2017). American Epic. When Music Gave America Her Voice. New York: Touchstone.

Margotin, P., \& Guesdon, J.-M. (2015). Bob Dylan: The Story Behind Every Track. All the Songs. New York: Black Dog Leventhal Publishers.

McCormick, N. (2012). Bob Dylan's Tempest: Rock's King Lyricist Keeps his Crown. Telegraph 07.11. https://www.telegraph.co.uk/culture/music/bob-dylan/9526332/

Bob-Dylans-Tempest-Rocks-king-lyricist-keeps-his-crown.html

McGinn, B. (1984). Early Apocalypticism: the Ongoing Debate. In C. A. Patrides \& J. Wittreich, (Eds.), The Apocalypse in English Renaissance Thought and Literature. (p. 2-39). Ithaca, NY: Cornell University Press.

McNeil, W. K. (Ed.). (1988). Southern Folk Ballads, vol. II. Little Rock: August House Publishers.

Mentz, S. (2015). Shipwreck Modernity: Ecologies of Globalization, 1550-1719. Minneapolis: University of Minnesota Press.

Mounce, R. H. (1998). The Book of Revelation. Revised edition. The New International Commentary on the New Testament. Grand Rapids: William B. Eerdmans Publishing Company.

Muir, A. (2019). The True Performing of It: Bob Dylan \& William Shakespeare. Cornwall: Red Planet Books.

Negus, K. (2008). Bob Dylan. London: Equinox.

New Revised Standard Version 1993. Cambridge Annotated Study Bible. Cambridge: Cambridge University Press.

Nurmi, M. K. (1970). Blake's Revisions of 'The Tyger. In M. Bottrall (Ed.), William Blake: Songs of Innocence and Experience. A Casebook. (p. 198-217). London: Macmillan.

Partridge, C., \& Moberg, M. (Eds.). (2017). The Bloomsbury Handbook of Religion and Popular Music. London: Bloomsbury.

Patrides, C. A., \& Wittreich, J. (Eds.). (1984). The Apocalypse in English Renaissance Thought and Literature. Ithaca, NY: Cornell University Press. 
People Take Warning! Murder Ballads \& Disaster Songs, 1913-1938. 2007. New York: Tompkins Square. CD. Disc 1, 2 and 3.

Poe, E. A. (2016). The Raven and Other Selected Poems. London: HarperCollins Publishers.

Rovira, J. (Ed.). (2018). Rock and Romanticism: Blake, Wordsworth, and Rock from Dylan to U2. Lanham: Lexington Books.

Rowland, C. (2016). William Blake and the Apocalypse. Oxford Research Encyclopedias. DOI:10.1093/acrefore/9780199340378.013.44

Sanville, G. W. (1943). Forty Gospel Hymn Stories. Winona Lake: The RodeheaverHall Mack Co.

Sapoznik, H. (2007). Liner Notes to "People Take Warning! Murder Ballads \& Disaster Songs", 1913-1938. New York: Tompkins Square. CD.

Selnes, G. (2016). Den store sangen. Kapitler av en bok om Bob Dylan. Oslo: Vidarforlaget.

Shelton, R. (2010). No Direction Home: The Life \& Music of Bob Dylan. Revised \& Updated Edition. London: Omnibus Press.

Smith, H. (ed.). (1997). Anthology of American Folk Music. Washington D.C.: Smithsonian Folkways.

Stokes, J. (2012). 'Long and Wasted Years': A Wedding Song Too? (A View from the Captain's Deck). The Bridge 44, 41-47.

Thomas, R. F. (2017). Why Dylan Matters. London: William Collins.

Thompson, T. (2012). The Transfiguration of Blind Boy Grunt. The Bridge 44, p. $79-85$.

Tillinghast, R. (1987). Bob Dylan and the White Goddess. The Missouri Review 1o/3, 172-176.

Turner, S. (2011). The Band That Played On. Nashville: Thomas Nelson.

Walker, L. (2018). Tangled Up in Blake: The Triangular Relationship among Dylan, Blake and the Beats. In J. Rovira (Ed.), Rock and Romanticism: Blake, Wordsworth, and Rock from Dylan to U2. (p. 1-17). Lanham: Lexington Books.

Weir, D. (2016). Bob Dylan. Song Analysis. Tempest. https://bobdylansonganalysis. wordpress.com/2016/03/16/tempest/

Wells, R. V. (2009). Life Flows On In Endless Song: Folksongs and American History. Chicago: University of Illinois Press.

Wilentz, S. (2010). Bob Dylan in America. London: The Bodley Head.

Wolfe, C. K. (1997). Folk Songs of Middle Tennessee. The George Boswell Collection. Knoxwille: The University of Tennessee Press.

Yaffe, D. (2011). Bob Dylan: Like a Complete Unknown. New Haven: Yale University Press. 


\section{Author description}

Robert W. Kvalvaag is professor at Oslo Metropolitan University, where he teaches religious studies at the Faculty of Teacher Education and International Studies. He has published three books (in Norwegian): From Moses to Marley, The divine I, and The Eleventh Commandment: Religion and Rock and Roll. Together with Pål Ketil Botvar and Reidar Aasgaard he also edited and contributed to Bob Dylan: The Man, the Myth and the Music. The writer of numerous articles on religion and popular culture published in anthologies and journals, his output has included works on Dylan's use of the Bible in the early songs, and a study of the influence of Hal Lindsey on Dylan's oeuvre in the so-called Gospel period.

\section{Forfatteromtale}

Robert W. Kvalvaag er dosent i RLE ved OsloMet, fakultet for lærerutdanning og internasjonale studier, hvor han underviser i religion, livssyn og etikk. Han har utgitt tre bøker: Fra Moses til Marley, Det guddommelige jeg, og Det ellevte budet. Religion og rock and roll. Sammen med Pål Ketil Botvar og Reidar Aasgaard var han redaktør for og leverte bidrag til boka Bob Dylan: Mannen, myten og musikken. Han har skrevet en rekke artikler i antologier og tidsskrifter om religion og populærkultur. To av disse handler om Dylan, den ene om den unge Dylans bruk av Bibelen, og den andre om Hal Lindseys innflytelse på Dylan i den såkalte gospel-perioden. 


\title{
CHAPTER 3
}

\section{Against Liberals: Multi-layered and Multi-directed Invocation in Dylan's Christian Songs}

\author{
Erling Aadland \\ Professor i allmenn litteraturvitenskap, Universitetet i Bergen \\ Professor of comparative literature, University of Bergen
}

\begin{abstract}
Bob Dylan's conversion to Christianity was a long time coming. So was his protest against protest, his hostility to politics. In this essay Dylan's gospel songs are appreciated as the pivot of his songwriting, augmenting the multi-layered sense and multi-directed meaning in the invocatory design of his songs, a pattern which of course is also to be found both earlier and later in his oeuvre.
\end{abstract}

Keywords: invocation, interpretation, description, sense, meaning

Sammendrag: Bob Dylans omvendelse til kristendommen var lenge forberedt i sangverket hans. Det samme gjelder hans protest mot protesten, hans forakt for politikk. I denne artikkelen blir Dylans gospelsanger betraktet som sangverkets omdreiningspunkt, for gospelsangene øker betydningsrikdommen og meningsmangfoldet i sangenes henvendelsesstruktur, en struktur som naturligvis også finnes både tidligere og senere i forfatterskapet.

Stikkord: henvendelse, fortolkning, beskrivelse, betydning, mening

But with the truth so far off, what good will it do? -Bob Dylan, Jokerman

\section{Against interpretation as exegesis}

In most poems (and songs) we may - perhaps rightly, perhaps not assume that the speaker (often verbally present as the "I" of the lyrics)

Citation of this chapter: Aadland, E. (2019). Against Liberals: Multi-layered and Multi-directed Invocation in Dylan's Christian songs. In R. W. Kvalvaag \& G. Winje (Eds.), A God of Time and Space: New Perspectives on Bob Dylan and Religion (p. 91-118). Oslo: Cappelen Damm Akademisk. https://doi.org/10.23865/noasp.74.ch3 Lisens: CC BY 4.0 
is referring to the same entity in all parts of the poem. The same applies to the addressee (the "you" of the lyrics) - and in this respect it makes no difference whether the entities in question are human, allegorical abstracts or transcendent beings. From where do these assumptions arise? The answer to this question, which may challenge the hermeneutic idea of reading as exegesis, may seem obvious: We derive the idea of the coherence of a poem's speaker (and addressee) from the idea of language functioning as communication.

But unfortunately, perceiving the lyric as patterned on communication implies an inadequate understanding of works of art, wholly unable to explain the blatant fact that lyrics exist at all. Undeniably, successful communication can be accomplished more effectively through other verbal and non-verbal means. So, we have to look for a healthier reason. We derive the idea of the coherence of a poem's speaker (and addressee) from the more substantial idea of the work of art as a unique and singular entity, and this idea with its strong Hegelian bearings seems to have survived even in the fragmented contextual and ideological mixture of current scholarship.

But this idea - the work of art perceived as a unique, sensual, and particular entity - cannot in and of itself be said to require the coherence of a poem's first person speaker and its second person addressee. The coherence of these entities is not called forth by anything other than the demands of interpretation, and in this essay I shall argue that rather than conceiving reading as interpretation and exegesis, as the cracking of "the nightingale's code", Dylan's oeuvre encourages readings understood as allowances of reading, the letting occur of readings, and perhaps we should be content with these allowances and occurrences and halt the superstitious pursuit of fully elaborated interpretations. In order to understand at all, we have to relinquish the neatness of complete understanding.

\section{"Ballad of a Thin Man"}

To pave the way for the wrestle with Dylan's evangelical and metaphysical songs an example shall briefly be invoked. The enigmatic "Ballad of a Thin Man" (1965) is a ballad, albeit of a special sort. The song tells a story 
of a kind, but not in the third person; the song is addressed to a second person. In the stanzas the "you" is never named, but in the refrain the addressee is called "mister Jones". It isn't, however, necessary to read the whole song as addressed to Jones, rather just the refrain. This might be unsettling seen from the point of view of interpretation, but it provides reading with new opportunities. The general and preferably allegorical meaning of the refrain (Jones understood as the ordinary man, each of us) can be seen as juxtaposed to the more particular, frightful, and disordering experiences of the more personalized "you" of the stanzas.

Perhaps the "you" of the stanzas is best understood as Dylan himself, not as a private man, of course, but as a highly creative mind struggling with his imagination. This line of thought also gives reading new opportunities regarding the ominous and perhaps also apocalyptic sense of the song, and makes it possible to read strands of the song's "you" as Christ himself - as imagined in His Second Coming.

These remarks demonstrate that what is either obvious or just slightly ambiguous on the level of description (of the lyrics' verbal sense) is far more enigmatic on the level of interpretation (of the meaning this sense is pointing out).

\section{Multiple sense and meaning of the addressee}

The listener may in many Dylan songs rightly be puzzled by the sense and the meaning (and reference) of the song's addressee. For example, is the sense of the song's "you" singular or plural? In most cases grammaticality may provide an answer; but questions still arise. Could the singular "you" (say of a song like "Positively Fourth Street", 1965) be a collective addressee (the Folk community at large) addressed as a singular metonymy rather than as a particular person? Furthermore, do the songs' "you" have an allegorical meaning in addition to the more personal one - for instance in love songs, which may have a particular and even biographical point of departure, but where the meaning of the (not any longer so deeply) loved one being addressed is extended allegorically, and in many cases even extends to transcendent meanings, related to inspirational forces, such as 
the Muses. The many Dylan songs with more or less obvious meta-lyrical strands of meaning are surely cases where a multi-layered addressee would be hard to avoid in accomplished readings.

"Tangled Up in Blue" (1975), a song with a long history of altered pronouns, especially in performances over a long period of time, is another example. Even in print the song's addressee does not easily read as a coherent entity. The song comes across as a first-person ballad, but the story is neither linear nor coherent. Rather, it is circular, and different stanzas are perhaps outlining largely unconnected scenes and persons. All in all, it seems to be necessary to allow for different senses and meanings regarding the song's "you" (including, or course, a reference to the Muses).

Much the same applies to other songs from the same period, for instance the raging "Idiot Wind" (1975), despite the song's close ties to other split-up and divorce songs from the mid-1970s. The song's addressee is obviously a figuration of the singer's wife, but this initial meaning is quickly enlarged and the addressee takes on both a metonymical extension, comprising the whole of American society in the 1970s, and a metaphorical (and allegorical) depth including spiritual warfare (stanza 4). The allusion to Roger McGuinn's "Chestnut Mare" (1970) in the fifth stanza is intriguing as well, and allows for inclusion of The Byrds' front man in the song's multiple addressee.

\section{The multiple speaker}

In spite of Dylan's quite frequent use of a multi-layered addressee, most songs would seem to lend themselves readily to readings where the coherence of the speaker need not be questioned. However, this is not always so. Dylan critics have often commented on the remarkable divergence between the speakers of the first, middle, and even the last part of "Sign on the Cross" (1967). The song is more polyphonic (also regarding the sense and meaning of the speaker) than most lyrical readings are usually prepared to allow for, and it would be a progressive leap for readings of the lyric if we were able to deal with this idea (the coherent entity of the 
speaker) as just a convenience and not a necessary piece of the nature of the lyric.

The idea of salvaging the coherence of the speaker by saying that he is giving voice to different personas, is not very helpful. The reason is that while "persona" (mask) is operating on the level of sense (description), and while the singer of a song is understandable only on the level of meaning and is, or was, a living entity, the speaker of a poem has no real existence, only a verbal and theoretical one. The meaning of the speaker cannot be reached by adding up his personas, his different senses, but must also include his pure tropological being, or rather, tropological beings.

Related to the question of the incoherence of the speaker of a poem, is the question of this speaker's sense. Is he more or less congruent with the singer himself, biographically or psychologically? Is he one or several masks (persons) the poet sees fit to hide his real and unknown face behind? Is the speaker another entity, quite different from the person who composed the poem, as could be the case in "Make You Feel My Love" (1997)? Literally the song reads just as well as the Lord speaking this love plea to man as the common perception of love songs would have it, that a man loving a woman indulges in singing his love plea out loud. A strange thing to do in any circumstance, perhaps silly too, and not at all in harmony with Dylan's long career of remodeling the love song - one of his great lyrical achievements.

\section{The blurring of coherent sense and unified meaning in some late songs}

There seems to be a discernable shift in Dylan's long song-writing career. Most of his early songs may fit the common sense perception of lyrical utterances, as patterned on communication. The songs address a more or less clearly perceived addressee, whose coherence doesn't need questioning, even though its sense might be ambiguous and multi-layered. This demonstrates that multiple sense (on the level of description) is not sufficient to make neither speaker nor addressee into incoherent enteties. The level of meaning (interpretation) has to be involved. 
After his resurfacing in the wake of the Americana-albums in the mid199os, Dylan changed a song-writing practice that from the start had been very much a patchwork of love and theft. From now on he didn't even bother much in trying to hide the stitches knotting the patches together and quoted more extensively than ever before.

The consequences are disputable. The obvious advantage is the inclusion of different and seemingly unrelated scenes, passages, and quotations, extending and deepening the feeling and worldview of the songs. On the other hand, coherent sense and unified meaning can be seen as being sacrificed for the unity of (an often time-honored) sound (and feeling). The long dialogue in the middle part of "Highlands" (1997) may serve as an example. Some love it, others don't. Unified sound and emotion can, however, be attained just as well alongside coherent sense and unity of meaning, fully demonstrated by many earlier Dylan songs.

The sacrifice, or, more carefully put, the blurring, of coherent sense and unified meaning is discernable in most of his later songs. For instance, the beginning of "The Levee's Gonna Break" (2006) is presented in the first person, and the "you" seems initially to have the sense "one", "any one person". But the addressee soon becomes more personalized ("I picked you up from the gutter and this is the thanks I get"), and in the seventh stanza the distinctions between the "I" and the "you" are wiped out: "Well, I look in your eyes, I see nobody other than me, / I see all that I am and all I hope to be." In the next stanza the distinctions are even more shattered: "When I'm with you, I forget I was ever blue, / Without you there's no meaning in anything I do." This might still be read as a fairly common love plea, albeit of a high romantic kind, which rhymes well with the consequential spite of the eleventh stanza: "I tried to get you to love me, but I won't repeat that mistake."

Okay, the end of a love affair. But this reading is quite incompatible with a more punctillious reading of the eighth stanza, as a pledge to Christ, a reading which is explicitly called for by the millennialist line in the tenth stanza: "Few more years of hard work, then there'll be a thousand years of happiness." 
The ambiguity of the addressee in this apocalyptic song might blur and even confuse the meaning (or message). On the other hand, it very well serves Dylan's purpose of transcending common sense, and speeds up the spiritual quest of his art. This urge is taken further in "Ain't Talkin"” (2006), another apocalyptic song, where the coherence of the speaker is most certainly questionable. The mystic garden in the song's opening line is obviously not just a natural place, but a site of spiritual contemplation and revelation - making Jesus a likely speaker of the song. If so, we have to concede that this is not a loving Jesus: "In the human heart, an evil spirit will dwell” (stanza 2) - "If I catch my opponents ever sleeping / I'll just slaughter 'em where they lie" (stanza 3).

Eventually this narrative coming from the mouth of Jesus in the Garden turns into a more personal plea from the mouth of Jesus (or the poet himself): "I practice a faith that's been long abandoned / Ain't no altars on this long and lonesome road"; but hope is added to misery: "Who says I can't get heavenly aid"; and the end of the final stanza ("Excuse me, ma'am, I beg your pardon: / There's no one here, the gardener is gone"), perhaps signifying the death of God, more likely means that God, according to plan, has abandoned Jesus at this crucial moment, and by metonymic extension will abandon any man, including the spiritual wanderer Bob Dylan.

A similar duality of desired salvation and violent rage, and a similar compounded speaker, appears in another late song, "Pay in Blood" (2012). The speaker is worn out and miserable, but his anger is outrageous: "I could stone you to death for the wrongs that you've done / Sooner or later you make a mistake, / I'll put you in a chain that you never will break / Legs and arms and body and bone/ I pay in blood, but not my own" (stanza 1). It would be inadvisable to read this speaker as a human being, rather he seems to be of heavenly origin: "The more I take the more I give. / The more I die the more I live" (stanza 2). The speaker must surely be Christ himself, addressing Satan: "I'm sworn to uphold the laws of God" (stanza 3). Therefore, not a loving Christ: "You bastard! I'm suppose [sic] to respect you? / I'll give you justice, I'll fatten your purse / Show me your moral virtue first" (stanza 5). And it gets worse: "You get your lover in the bed. / Come here, I'll break your 
lousy head. / [...] / I came to bury, not to praise. / I'll drink my fill and sleep alone / I pay in blood, but not my own" (stanza 6). (The lyrics of this song are quoted from dylanchords.info. Bobdylan.com renders the lyrics incompletely.)

The speaker seems to be a composite of a vengeful Christ and a vindictive Christian upholding the laws of God by literally acting out the doctrine of transubstantiation.

\section{Longstanding themes peaked in the years of conversion}

Dylan's conversion to evangelical Christianity shocked many of his listeners and left most rock pundits astonished. He had been a cherished asset of the liberal left for two decades, despite the ostensible break with the protest song, the civil rights movement, and the liberal left - first through the infamous speech upon receiving the Tom Paine Award late in 1963, and unequivocally in 1964.

Arguably, Dylan's gospel songs are the decisive backdrop for the changes, outlined above, in the later part of his oeuvre. The shattering of common sense perception and the disdainful neglect of mundane concerns can be seen as a prolongation of the explosion of Dylan's protest impulse - obviously a vital part of his creative urge all his life - which appeared so forcefully in the gospel years.

Dylan songs were always tapestries, collections of pieces of information, perception, allusion and argument - aphorisms, dialogues, quotations, narratives, invectives and so on. Though many of his songs featured coherence of sense and unity of meaning, these features rarely were Dylan's main concerns. His songs were always more about unity of sound and an unimpeded urge to transcend the common sense level of perception, apprehension and understanding. This line of reasoning makes his gospel rock the pivot of his song-writing career, both in terms of transcendence and in terms of techniques of lyrical design - but concededly not always in terms of lyrical subtlety. 
In the gospel songs the longstanding themes of Dylan's oeuvre became highlighted. His rage against greed ("flesh-colored Christs that glow in the dark", "It's Alright, Ma", 1965) and both mundane and spiritual corruption, his adversity to commercialism, consumer society and the grand but false promises of materialism, and his war on the inclination to wipe out personal responsibility in the age of politically correct voluntarism all these themes can be traced throughout his long career.

\section{From human will to divine providence}

Dylan emerged as a renowned artist, songwriter and political activist early in the 196os, particularly through the so-called protest songs, songs about civil rights issues, often cast in a judicial vocabulary, but with broader social and political perspectives as well. He also wrote about other typical liberal issues, and was embraced by the American left, and soon after by leftists all over the world.

The embrace was, however, perhaps too hard, and probably also felt to be impeding his artistic freedom. Dylan revolted and at one point he wanted to give up singing and song-writing altogether, but the intent came to naught; and it should be noted that the songs he wrote in the following years, when he reached the summit of rock stardom and a worldwide popularity he later only rarely and briefly regained, have more political and social depth than his earlier topical songs. He also reached the summit of infamy, the 1966 world tour being accompanied by constant shouts of disapproval coming from large (and probably leftist) parts of the audiences.

Dylan's songs from the 1970 are less political than the songs of the previous decade, but they are still social commentaries by virtue of being songs of love and marriage with much societal echo. With a few exceptions, explicit political issues are absent. One exception is the protest song "Hurricane" (1975), but at the same time Dylan wrote the ballad "Joey", a tribute to the gangster Joey Gallo. Again he claimed his autonomy and artistic courage. 
Towards the end of the 1970s Dylan, as the story goes, experienced an epiphany, converted to evangelical Christianity and started a manic production and frenzied performance of gospel rock songs. The new songs are decidedly more fiercely protest songs than the cherished songs from the 1960s. This provoked his fans even more than his farewell to the civil rights movement and the liberal left.

Dylan was criticized for judgmental songs and a missionary posture, because these are songs admonishing non-believers to seek redemption before it's too late: "Now there's spiritual warfare and flesh and blood breaking down / Ya either got faith or ya got unbelief and there ain't no neutral ground. / The enemy is subtle, how be it we are so deceived / When the truth's in our hearts and we still don't believe?" ("Precious Angel", 1979). It's all about taking sides. In "Gonna Change My Way of Thinking" (1979) Jesus is quoted as saying: "He who is not for Me is against Me" (cf. Luke 11: 23), echoed in the old labor song "Which Side Are You On", explicitly referenced in "Desolation Row" (1965).

Dylan embraces the thought that the world is not governed by human will, but by divine providence. This is perhaps the main reason why songs from the latter part of his oeuvre neither have got nor can get the same approval as his early work - because voluntarism, the will to will, the ontological foundation of the present age of Western decline, is sharply at odds with Dylan's Christianity.

\section{Apocalypse and Christ-identifications}

In hindsight it is easy to see that Dylan's Christian songs didn't appear out of nowhere. Apocalyptic songs abound throughout his oeuvre. Many of the protest songs are apocalyptic, for instance "The Times They Are A-Changin"' (1963), a song with flood-images referencing The Great Flood (Noah) and Exodus, and with quotations from the Sermon on the Mount about the final judgment. Eschatology is of course the most pertinent and unifying feature of Dylan's gospel songs. They are all about salvation or damnation. The misinterpretation of "The Times ..." by leftists, claiming that this is a song about the generation gap and the surging youth revolt, will probably not be judged kindly by future scholarship. 
The left, which, with few exceptions, has dominated Dylan-scholarship, has no problems with apocalypse as such. Leftist ideology is founded on a secular tale about class struggle and revolutions, and, besides, it is undeniable that apocalypse is one of the original tales of Western civilization from Gilgamesh and Noah to the visions in the Book of Revelation - and further on in secular events like the decline and fall of the Roman empire, the great plague, the French revolution, holocaust, the nuclear threat and contemporary fear of an imminent climate crisis. Even the left approves of apocalypse, but it doesn't approve of Christianity. And metaphysical Christianity that cannot be stowed away as a cultural oddity, apocalypse coupled with ardent personal faith, is not at all likeable to leftists.

What happened in 1967, after the accident, is another sign of what was to come. Dylan immersed himself in Americana, like he had done around 1960, and like he did several times later. In Woodstock he and the band recorded a substantial oeuvre, partly new songs, partly sundry traditional material, including gospel songs and songs with an ambiguous religious urge, like the above-mentioned "Sign on the Cross". And in the autumn of 1967 Dylan recorded John Wesley Harding, an album of moral and religious parables, one of them being "All Along the Watchtower", referencing the prophecy of the fall of Babylon. Also New Morning (1970) includes many religious allusions, and introduces usage of the gospel choir.

Remarkable are the Christ identifications in 1970s songs which otherwise deal with love, marriage and divorce, like "Idiot Wind" and "Shelter from the Storm" (1975). The first sings: "There's a lone soldier on the cross, smoke pouring out of a boxcar door / You didn't know it, you didn't think it could be done, in the final end he won the wars / After losin' every battle"; while the second says: "She walked up to me so gracefully and took my crown of thorns". These passages foreshadow crucifixion-references in later songs: "Swords piercing your side" ("Gonna Change My Way of Thinking”, 1979); “There's a Man on a cross and He's been crucified for you" (“When You Gonna Wake Up?", 1979); and the much later "We all wear the same thorny crown" ("When the Deal Goes Down", 2006).

And on the album released prior to the epiphany of 1978, Street-Legal, there are several songs presaging the conversion. The penultimate stanza of "Changing of the Guards" prophesies: "Gentlemen, he said / I don't 
need your organization, I've shined your shoes / I've moved your mountains and marked your cards / But Eden is burning, either brace yourself for elimination / Or else your hearts must have the courage for the changing of the guards". (Incidentally, the shoe-motif just cited reappears in "I and I" (1983): "I've made shoes for everyone, even you, while I still go barefoot".)

And "Señor (Tales of Yankee Power)" mentions "an iron cross still hanging down from around her neck", before it ends with a reference to how Jesus expelled the money lenders from the temple (Matt 12): "Señor, señor, let's disconnect these cables / Overturn these tables / This place don't make sense to me no more / Can you tell me what we're waiting for, señor?"

Although it would be inadvisable to read too much pre-Christianity into early Dylan songs, it cannot be denied that he was both fully immersed in the traditional Christian song-bag and almost obsessed with biblical and Christian themes.

\section{Christian rage}

The apocalyptic songs, a pertinent feature in all of Dylan's phases, do culminate in his gospel years. A feeling of imminent Judgment is central to evangelical Christianity, and calls for resoluteness. The presence of this theme in Dylan's gospel rock, and throughout his later work as well, is almost infinite, permeating the songs from top to bottom. A few examples: "Can they imagine the darkness that will fall from on high / When men will beg God to kill them and they won't be able to die?" ("Precious Angel”, 1979); "Are you ready for the judgment? / Are you ready for that terrible swift sword? / Are you ready for Armageddon? / Are you ready for the day of the Lord?" ("Are You ready", 1980); "I see pieces of men marching, tryin' to take heaven by force / I can see the unknown rider, I can see the pale white horse" (Angelina, 1981); "Only a matter of time 'til night comes steppin' in" (“Jokerman”, 1983); “Tomorrow all activity will cease" ("Man of Peace", 1983); "The word could come to an end tonight, but that's all right" ("I and I", 1983); "As the last firetruck from hell / goes rolling by, all good people are praying / It's the last temptation the last 
account / The last time you might hear the sermon on the mount / The last radio is playing" ("Shooting Star", 1989).

There's no need to deal extensively with this subject, mainly because it is obvious. Instead, it would seem wise, in view of the criticism aimed at his gospel songs, to try to encircle Dylan's Christianity (aided by Stephen H. Webb's book Dylan Redeemed, from Highway 61 to Saved, 2006, a truly invaluable piece of Dylan scholarship). In this way my subsequent remarks on the invocatory pattern of these songs can gain pertinence and importance.

Dylan's gospel songs are criticized for theological exclusivity. This is, however, pointless, since eschatology is and has to be discriminative: "When destruction cometh swiftly / And there's no time to say a farethee-well, / Have you decided whether you want to be / In heaven or in hell?" ("Are You Ready?", 1980). Some years later "Ring Them Bells" (1989) puts it like this: "For the chosen few / Who will judge the many / When the game is through"; and "Ain't Talkin' (2006) says: "There'll be no mercy for you once you've lost".

On the other hand, "Gotta Serve Somebody" (1979) seems to be all-inclusive, at least on its surface: We are either serving God or Satan. But the song is not just descriptive, it is prescriptive too, and projects service onto the future: one day you will have to decide whom you shall serve.

The gospel songs are also accosted for preaching with fire and brimstone. Rage is, however, nothing new in Dylan, but compared with the Christian songs, songs such as "Positively Fourth Street" or "Like a Rolling Stone" (both 1965) are more easily managed because the rage seems to be directed against a third party. Listeners are siding with the speaker, while in the Christian songs rage is directed at the audience (see Webb, 2006, p. 92).

The rage is triggered by the imminence of Doomsday. Until Christ returns earthly peace is an illusion: "Will I ever learn that there'll be no peace, that the war won't cease / Until He returns" ("When He Returns", 1979); "For me He was chastised, for me He was hated, / For me He was rejected by a world that He created. / Nations are angry, cursed are some, / People are expecting a false peace to come" ("Solid Rock", 1980); "No kingdom made of human hands can stand" ("Yonder Comes Sin", 1980). 
As Webb argues, more and more human and humanitarian love cannot make right the wrongs of the world. For instance, "Man of Peace" (1983) is not just saying that Satan is dressed up as a humanitarian philanthropist: "He's a great humanitarian, he's a great philanthropist, / He knows just where to touch you, honey, and how you like to be kissed. / He'll put both his arms around you, / You can feel the tender touch of the beast. / You know that sometimes Satan comes as a man of peace" (stanza 6); but the song also says that good intentions may easily end up producing evil results: "He got a swift gift of gab, he got a harmonious tongue, / He knows every song that ever has been sung. / Good intentions can be evil [...]” (stanza 2). (See Webb, 2006, p. 88.)

\section{Social criticism in the gospel songs}

The claim that there's a lack of a progressive social program in the gospel songs, is surely false. The social criticism in the gospel songs is both more fierce and wide ranging than ever before in Dylan. But rather than turning to simple, superficial, and favored liberal issues like oppressed minorities, which he used to do, and which still after all these years of worldwide changes on a grand scale seem to be the darling issues of liberals, he now bites into more unpleasant and dangerous contemporary features:

Sexual confusion and disorder, with "Sons becoming husbands to their mothers, / And old men turning young daughters into whores" ("Gonna Change My Way of Thinking”, 1979), or as "Trouble in Mind” (1979) says: "Satan whispers to ya, 'Well, I don't want to bore ya, / But when ya get tired of that Miss So-and-so I got another woman for ya" - in brief, "the politics of sin" (“Dead Man, Dead Man”, 1981).

Attacks on other religions and New Age-like spiritual substitutes: "You were telling him about Buddha, you were telling him about Mohammed in one breath, / You never mentioned one time the Man who came and died a criminal's death" ("Precious Angel”, 1979), or as "When You Gonna Wake Up?" (1979) is observing: "Counterfeit philosophies have polluted all of your thoughts. / Karl Marx has got ya by the throat [...]" and "Spiritual advisors and gurus to guide your every move, / Instant inner peace and every step you take has got to be approved." 
And on science: "Don't wanna learn from nobody what I gotta unlearn" and "Don't put my faith in nobody, not even a scientist" ("Do Right to Me, Baby", 1979); "They like to take all this money from sin, build big universities to study in / Sing 'Amazing Grace' all the way to the Swiss banks" ("Foot of Pride", 1983); "I don't care about economy / I don't care about astronomy" ("Slow Train", 1979); "the world of research has gone berserk / Too much paperwork" ("Nettie Moore", 2006).

The world is in disorder; violence and turmoil on the one side, cockeyed arrogance on the other: "Groom's Still Waiting at the Altar" (1980) is singing: "Cities on fire, phones out of order, / They're killing nuns and soldiers [...]", while "Dead Man, Dead Man" (1981) is saying: "What are you tryin' to overpower me with, the doctrine or the gun? / My back is already to the wall, where can I run?"

Arabian sheiks are up for a swipe as well: "All that foreign oil controlling American soil, / Look around you, it's just bound to make you embarrassed. / Sheiks walkin' around like kings, wearing fancy jewels and nose rings, / Deciding America's future from Amsterdam and to Paris" (stanza 3, "Slow Train", 1979), while isolated Israel is praised in "Neighborhood Bully" (1983).

\section{"The politics of sin"}

"The politics of sin" designate the power, corruption, self-righteousness, and falsity of the profane world. In this world righteous life is just not attainable. Only in the other world, the world of faith, can righteous life be fulfilled, and this other world is breaking into the profane world with terror and liberation, turning hierarchies upside down. The man who acknowledges this becomes a holy outlaw. Jesus Christ as the ultimate outlaw, embodying the paradox of victory through defeat, progressing from crucifixion to resurrection, is the pivotal figure of this collision of earth and spirit.

Thoughts like these might provoke those who have abandoned Christianity. The justice Dylan is pleading for now, "justice's beautiful face" ("I and I", 1983), no longer advances the liberal redistribution of wealth and reduction of social differences. In 1962, in "North Country Blues", he sang 
about the ravages of global capitalism: a mining town where employment has gone up and down, until the mines are finally shut down. The speaker of the song is a mother who has lost most of her family in the mines. The mines are closed, leaving behind a ghost town. The seventh stanza explains why: "They complained in the East, they are paying too high. / They say that your ore ain't worth digging. / That it's much cheaper down in the South American towns / Where the miners work almost for nothing."

This stanza is not only interesting in that it, more than 50 years ahead of Donald Trump, says what he, and Bernie Sanders too, repeatedly opined in the 2015-2016 presidential campaign, but also because it prefigures another Dylan song, "Union Sundown" (1983), which, 30 years ahead of Trump and Sanders, says: "Well, my shoes, they come from Singapore / My flashlight's from Taiwan / My tablecloth's from Malaysia / My belt buckle's from the Amazon / You know, this shirt I wear comes from the Philippines / And the car I drive is a Chevrolet, / It was put together down in Argentina / By a guy makin' thirty cents a day" - before the refrain concludes: "[...] it's sundown of the union / And what's made in the USA / Sure was a good idea / 'Til greed got in the way."

A tougher go at global capitalism, and also at the other meaning of "union", the trade unions: "The unions are big business, friend / And they're going out like a dinosaur". Democracy, as well, is abandoned: "Democracy don't rule the world / You'd better get that in your head". But as Webb suggests, globalization is perhaps not the heart of the matter. The last stanza says: "This world is ruled by violence / But I guess that's better left unsaid." He has said it, but simultaneously made it clear that no one will bother about his saying it: that there's something seriously wrong with human nature, which no politics can mend, original sin (Webb, 2006, p. 56-57).

\section{Animosity towards politics}

To rank religion above politics is conservative, perhaps even reactionary. But is it at all conservative or reactionary, or the opposite for that matter, to sideline politics completely? "Political World" (1989) is a crucial song in this respect: "We live in a political world / Where peace is not welcome at 
all". The song not only says that politics is not the answer, but in fact the very problem. We use the language of politics to avoid personal responsibility and in order to justify the cravings of our sinful nature (Webb, p. 55-56). For Dylan history is primarily the history of salvation and damnation. Mundane history and politics are only to be found enclosed within these categories. Dylan is not only uninterested in politics, he rejects any political thought and makes it part of the realm of evil. This in no way disqualifies his songs from having ideological impact, and it is noteworthy that the only period when he spoke directly about the political world (of sin) - both on and off stage - was precisely the conversion years of 1979 and 1980 .

Dylan's notion of Christ is conservative as well (Webb, 2006, p. 17), eschatological as it is, and not drawn from the tolerant point of view of contemporary mainstream Christianity. Tolerance is certainly of considerable value, but when it becomes absolute, its potential for social criticism seems to be emptied out. Many liberals are so tolerant of all kinds of dubious identity politics that they find it hard to criticize even the most appalling moral decay. Dylan seems to have been aware of these problems long before the criticism of political correctness became a regular issue.

Many can go along with this, but fewer will acclaim the theology of evil that is Dylan's answer to the contemporary mainstream flirt with absolute tolerance. In Dylan's view Satan is not clothed in moral vice, but rather materializes in the inner voice of the deadened conscience, saying that everything is all right and making us worship the works of human hands: "Here comes Satan [...] / [...] / He's gonna deaden your conscience 'til you worship the work of your own hands, / You'll be serving strangers in a strange, forsaken land" (stanza 3, "Trouble in Mind", 1979). Or as "Slow Train" puts it: "Fools glorifying themselves, trying to manipulate Satan”.

\section{Original sin}

The notion of man's sinful nature seems to have a long history in Dylan. In his early anti-war songs a feeling of the futility of human effort is detectable. Our freedom is limited by weakness and fallibility. (See Webb, p. 51-52.) 
"Saved" (1980) puts the point astutely: "I was blinded by the devil, / Born already ruined, Stone-cold dead / As I stepped from the womb"; and so does "Yonder Comes Sin" (1980): "I can read it in your eyes, oh, what your / Heart will not reveal / And that old evil burden has been draggin' you down, / bound to ground you 'neath the wheel"; and "Pressing On" (1980): "Temptation's not an easy thing, Adam given the devil reign / Because he sinned I got no choice, it run in my vein." In a similar fashion "Trouble in Mind” (1979) pleads: “[...] how long, Lord, must I be provoked? / Satan will give you a little taste, then he'll move in with rapid speed."

Evil, the work of Satan, is inherent in human nature, and the strongest of alienations, because it is not political or social, but metaphysical. "Pressing On" (1980) sings: "You know the adversary never sleeps - he is a roaring beast. / He always comes at the time that you expect him least. / And you know that he's responsible for death and pain and loss, / But we know we'll overcome him by the victory of the cross" (additional third verse sung November 4, 1979, cited from dylanchords.info). And "You Changed My Life" (1981) sings: “There's someone in my body that I could hardly see / Invading my privacy making my decisions for me / Holding me back, not letting me stand / Making me feel like a stranger in a strange land" (stanza 6). "Property of Jesus" (1981) puts the point in the form of a rhetorical question: "But you've picked up quite a story and you've changed since the womb. / What happened to the real you, you've been captured but by whom?"

The appearance of the Prince of Darkness in the songs is massive. "Yonder Comes Sin" (1980) speaks of "your uninvited guest", while "Angelina" (1981) says that "[y]our best friend and my enemy is one and the same". "Man in the Long Black Coat" (1989) sings: "Somebody said from the Bible he'd quote", while "Ain't Talkin" (2006) sums it up: "In the human heart, an evil spirit will dwell." Similarly in "Shot of love" (1981): “There's a man that hates me and he's swift, smooth and near, / Am I supposed to set back and wait until he's here?"

We are free but still forced to sin, and each of us is alone responsible for his sins. We can be saved only through God's interference. A strong belief in original sin can easily lead to inertia, but the insistence on personal responsibility balances this tendency to fatalism. 
Evangelical theology is no idealism, Webb argues, but preaches a personal responsibility at odds with idealistic voluntarism. Dylan clearly despises the doctrine of liberal idealism, which preaches that human beings are essentially good, and that evil is the offspring of society and circumstance. He treats the liberal mock-praise of the freedom of speech with contempt. "Caribbean Wind" (1981) depicts men bathed in perfume practicing "the hoax of free speech", while "them distant ships of liberty on them iron waves so bold and free, / Bringing everything that's near to me nearer to the fire".

\section{The invocatory design of the gospel songs}

A large number of Dylan's gospel songs, as well as later songs imbued with Christianity, have this pattern: a first person speaker (often verbally present as the "I" of the lyrics) addresses a second person. In most of these songs both the speaker and the addressee have a multiple sense: the speaker is the redeemed convert who through conversion has received a visionary and prophetic gift and can address his audience with fervor and credibility, while he at the same time is part of the collective "you", at least in his former state as unbeliever. In short, the speaker is a composite of sin and vision, while the addressee has a multitude of sense - each of us, fallen man, the audience, the congregation, and even the whole mundane world personified.

This pattern is typical of songs like "Gotta Serve Somebody (1979), "When He Returns" (1979), "Ye Shall be Changed” (1979), "Saved” (1980), "Solid Rock" (1980), "Pressing On" (1980), "Are You Ready" (1980), "City of Gold” (1980), "Watered-Down Love” (1981), “The Groom's Still Waiting At The Altar” (1981), "Dead Man, Dead Man” (1981), “Trouble” (1981), "Union Sundown” (1983), "Disease of Conceit" (1989), "Dignity” (1989), and many more.

In addition to its multiple sense, the addressee in some songs designed like this have a multi-directed meaning, in as much as the addressee obviously also is the Lord, at least in parts of the lyrics. This is the case in "Gonna Change My Way of Thinking” (1979): “O, Lord, you know I have no friend without you"; while in other songs the addressee gets the 
additional meaning of a physical lover, as in "When You Gonna Wake Up?" (1979): "You got some big dreams, baby [...]", and in "Man of Peace" (1983): "Look out your window, baby [...]”; "He knows just where to touch you, honey [...]".

In some songs of this kind the addressee, besides signifying each of us as sinners, also signifies Satan, and sometimes even both Satan and the Lord in different parts of the song, as in "Shot of Love" (1981): "I don't need no alibi when I'm spending time with you" (possibly referring to the Lord), and "Why would I want to take your life? / You've only murdered my father, raped his wife / Tattooed my babies with a poison pen / Mocked my God, humiliated my friends" (probably referring to evil if not outright to Satan himself). The same seems to apply to "Jokerman" (1983), where the addressee sometimes has satanic, at other times Christ-like, features, and even a third sense involving, and a third meaning referring to, the artist himself as being drawn between Satan and the Lord. In "You Changed My Life" (1981) the speaker is as stated above, while the multiple addressee includes both all sinners (including the speaker) and Christ (both in the refrain and the last stanza). In "Yonder Comes Sin" (1980) the addressee seems to have a multitude of sense and meaning: the speaker addressing himself, all sinners, a loved one, and Satan.

This brief summary of the invocatory nature of a large part of Dylan's Christian songs amply demonstrates that the blurring of sense and confusion of meaning I mentioned earlier in connection with some of his later work have a long history of preparation. The same is true for another and even more interesting feature of the gospel songs: some of them not only have a multiple sense and a piecemeal multi-directed meaning, but a pervading duality of both sense and meaning.

\section{Dual invocation}

Remarkably few of Dylan's gospel songs have a third person presentation. Exceptions are "In the Garden" (1980) and "Property of Jesus" (1981). First person presentation in balladic style without invocation of an addressee is also fairly rare, but does appear in songs like "Caribbean Wind" (1981) and "Blind Willie McTell" (1983). 
Songs with a dual invocation are fairly uncommon as well, but there are several of them, and the tendency is detectable in quite a number of songs. In spite of the multiple senses of the two addressed entities, the duality is fairly clear-cut between an earthy (sensual) and a divine (transcendent) extremity.

"Precious Angel" (1979) is a song with a dual invocation throughout the lyrics. Sometimes the addressee reads as a lover: "You're the queen of my flesh, girl, you're my woman, you're my delight. / You're the lamp of my soul, girl, and you torch up the night" (stanza 6). But this lover also has the aura and qualities of a Muse and of divine guidance and salvation, maybe even of Christ himself as the Muse of conversion: "Precious angel, under the sun, / How was I to know you'd be the one / To show me I was blinded, to show me I was gone / How weak was the foundation I was standing upon?" (stanza 1).

The speaker remains as outlined above, sinful man in need of redemption - this is evident from the words of the refrain: "Shine your light, shine your light on me / Ya know I just couldn't make it by myself. / I'm a little too blind to see." This "you" of the refrain signifies the sun, a precious lover, the Lord.

In some passages one might be tempted to include even a third addressee, the audience, or the world at large, or more specifically the lover before her conversion: "Sister, let me tell you about a vision that I saw / You were drawing water for your husband [...] / You were telling him about Buddha [...]" (stanza 4). This is well adjusted to the second stanza's spiritual warfare: "Ya either got faith or ya got unbelief and there ain't no neutral ground. / The enemy is subtle, how be it we are so deceived / When the truth's in our hearts and we still don't believe?"

This theme of resolve is of course innately coupled with the song's apocalyptic features, and implies the visionary and prophetic gifts of the speaker, chiding his "so-called friends": "Can they imagine the darkness that will fall from on high / When men will beg God to kill them and they won't be able to die?" (stanza 3), and the last stanza's journey towards the final judgment: "But there's violence in the eyes, girl, so let us not be enticed / On the way out of Egypt, through Ethiopia, to the judgment hall of Christ" (stanza 6). 


\section{Duality of sense and meaning}

A similar invocatory pattern appears in "I Believe in You" (1979): the speaker is the compound we have already outlined as sinful man seeking redemption and blissful convert with a visionary gift, though the latter is not very prominent in this song. The first two stanzas are telling the addressee how "they" (the unbelievers) treat the speaker with contempt, condescension and even outright animosity: “They'd like to drive me from this town" (stanza 1); "They say don't come back no more" (stanza 2). But the speaker isn't discouraged, because he believes "in you", and the last two stanzas speak directly to the addressee in the mode of a prayer: "Don't let me drift too far" (stanza 3); "Don't let me change my heart" (stanza 4).

This addressee has a similar duality of sense and meaning, as mentioned above. The invocations seem to be predominantly directed at the Lord: "Keep me where you are / Where I will always be renewed" (stanza 3); "Keep me set apart / From all the plans they do pursue" (stanza 4). The second refrain makes this fairly obvious: "I believe in you when winter turn to summer, / I believe in you when white turn to black, / I believe in you even though I be outnumbered". But this doesn't contradict the other mentioned sense of the addressee, the fellow converted lover, almost impossible to miss in the third of the following lines from the first refrain: "I believe in you even through the tears and the laughter, / I believe in you even though we be apart. / I believe in you even on the morning after".

"In the Summertime" (1983), "Shooting Star" (1989), and "This Dream of You" (2009) present a similar dual addressee: the physical lover and the transcendent divinity. The speaker of "In the Summertime" is not so much sinful man as the redeemed convert, and the salvation (or the ignition of a love affair) came swiftly: "I was in your presence for an hour or so / Or was it a day? I truly don't know". The adversity of the unbelievers is very much present: "Fools they made a mock of sin / Our loyalty they tried to win" (stanza 2); "Strangers, they meddled in our affairs / Poverty and shame was theirs" (stanza 3 ). The exquisite ambiguity of "saved" (preserved and redeemed) in these lines from the third stanza is well worth noticing: "And I'm still carrying the gift you gave / It's a part of me now, 
it's been cherished and saved,/ It'll be with me unto the grave / And then unto eternity."

At first glance "Shooting Star" reads as a melancholy plea to a lover lost, but the line "You were trying to break into another world" (stanza 1) and the apocalyptic bridge ("Listen to the engine listen to the bell / As the last firetruck from hell / goes rolling by, all good people are praying / It's the last temptation the last account / The last time you might hear the sermon on the mount / The last radio is playing"), make it fairly apparent that we are dealing with an addressee with at least transcendent aspirations and probably transcendent qualities too.

In much the same manner the addressee of "This Dream of You" at first glance seems to be a distant and lost but still loved woman, but this impression is disturbed by the rhetoric and comprehensive scope of refrain and bridges: "All I have / and all I know / is this dream of you / which keeps me living on" (refrain); "I don't wanna believe / But I keep believing it" (first bridge); "Everywhere I turn / you are always here / I run this race / until my earthly death / I'll defend this place / with my dying breath" (second bridge).

\section{Duality of genre, speaker and addressee}

The woman in "Covenant Woman" (1980) has the mentioned spectrum of sense stretching from (fellow convert) lover to soul mate, and even to inspiring Muse. But in this song another kind of duality appears, a duality of genre: The song is simultaneously a love song and a spiritual tribute, much in the manner of "What Can I Do for You?" (1980), even though the addressee of the latter is unequivocally transcendent.

In "I and I" (1983) the duality is located within the speaker, while the addressee seems to be all of mankind, and more specifically the singer's and the song's audience. The speaker is still the redeemed convert with a visionary gift for examining the secrets of the world, but someone else is speaking through him, or rather for him, through his heart, his innermost house of being: "Someone else is speakin' with my mouth, but I'm listening only to my heart." Christ himself seems to have become a part of the speaker's house of utterance. 
In "When the Deal Goes Down" (2006) we again face a dual addressee. The "you" of the song seems to signify all mortals, and the speaker seems to address all of us as a companion, but eventually the addressee takes on another sense as well, the Lord: "You come to my eyes like a vision from the skies" (stanza 3); "I owe my heart to you, and that's saying it true" (stanza 4). And this duality on the level of description (sense) makes it almost impossible not to include, on the level of interpretation (meaning), the Lord in the speaker as well: "And I'll be with you when the deal goes down".

\section{From evangelism to providentialism}

The gospel protest phase was just as brief as Dylan's early and politically correct protest period, approximately two years. The evangelical revival ended quickly, and Dylan fans, predominantly atheists with a liberal agenda, have, through the subsequent years, been looking for signs of Dylan the apostate. But the signs never became clear, rather the opposite: "And I'm still carrying the gift you gave, / It's a part of me now, it's been cherished and saved, / It'll be with me unto the grave/ And then unto eternity" ("In the Summertime", 1981). Dylan's late work is imbued in Christianity, albeit of a kind that seems hard to identify.

Webb explains this well. Dylan moved from evangelism to providentialism, which professes confidence in divine providence, an outlook that minimizes human will and action. It springs out of a long historical tradition which has its intellectual basis in Calvinism's doctrine of predestination. Revivalism depends too much on the will; it encourages bravery and action, but the belief in providence is more down to earth. The holy is found in details rather than in ecstatic experience. (See Webb, 2006, p. 162.)

Webb sees signs of Dylan already moving from evangelism on the second gospel album, Saved (1980); and on the third, Shot of Love (1981), he spots two songs articulating the new orientation. "In the Summertime" deals with the public ridicule the singer has been subjected to, something that has led to his faith becoming more private and durable. The song quotes Romans 8: 18: "I consider that our present sufferings are not worth 
comparing with the glory that will be revealed in us." The song puts it like this: "But all that sufferin' was not to be compared/ With the glory that is to be" (stanza 3), making the song, as already mentioned, both a profane and a heavenly love story. (See Webb, 2006, p. 163.)

And "Every Grain of Sand" (1981) shows how providence is the answer to the problems of revivalism. The song deals with liberation of the self through confidence in God's providence: "Toiling in the danger and in the morals of despair. / Don't have the inclination to look back on any mistake, / Like Cain, I now behold this chain of events that I must break. / In the fury of the moment I can see the Master's hand / In every leaf that trembles, in every grain of sand" (stanza 1-2). The singer will not look back; instead he will break the causality chain. The futility of his despair tells him to leave everything in the hands of God. Only through faith in God's creation can we step into the future (Webb, 164).

However, providentialism is no happy faith. It takes a lot of hope and patience to believe that everything is happening as a result of a hidden reason. The words "and a world to come that's already been predetermined" ("Jokerman", 1983), in the dual portrait of Jesus and Satan, and the artist's inclination to be drawn to both of them, are quite telling. Religious despair permeates many songs throughout the 1980s, particularly the album Oh Mercy (1989), but according to Webb the album most influenced by provindentialism (and negative theology) is Time Out of Mind (1997). (See Webb, 2006, p. 166.)

\section{No congenial reception to be expected in today's universities}

Dylan's adversity to the liberal belief in man's essentially good nature is highlighted in his criticism of the belief that human effort can create a perfect world (postmillennialism): the Second Coming shall occur after the establishment of the Millennium. According to Webb, this is sentimental mainstream Christianity, over-optimistic on behalf of human capacity for goodness, believing that social reformers have sown the seeds of Utopia and that Christ won't return until we have met him midway. (See Webb, p. 94-95.) 
The opposite is premillennialism, implying that the world shall come to a terrible end before Christ establishes the Millennium. This thought is permeated by a distrust of human nature. At its worst it can lead to paranoia and misanthropy, both of which have, at times, been present in Dylan, but at its best it fills his songs with a serious desperation (Webb, 2006, p. 95-96). As Webb laconically puts it: "Dylan trusts himself, not his audience. He is authentic, not sincere" (Webb, 2006, p. 118). And: "The authentic does not need to be trusted. It just needs to be expressed” (Webb, 2006, p. 119).

Dylan's religious quest is spiritually challenging. It pushes us in the direction of the Lord by pushing us beyond the borders of knowledge - a way of thinking that liberal citadels like today's universities will find it almost impossible to handle. The antagonism between art and current scholarship makes it hard to believe that Dylan's Christian protest songs will ever enjoy the sort of warm reception his earlier protest songs have been granted.

\section{Multiple sense and meaning on the levels of description and interpretation}

As we have seen, we may - or rather, forced by truth, we have to - acknowledge a multi-directed invocation in Dylan songs, both earlier and late ones. The difference between earlier and later songs is not discernable in this broad picture, but rather in the way the multi-directedness is being played out in the web of the songs' more or less unified meaning. Quite a number of Dylan's later songs seem inclined to relinquish unified meaning and relish in a unity of feeling, sound, or rhetorical amplification, which certainly produces endless labor for critics, while it also might conceal the possible deterioration of Dylan's lyrical genius. Or perhaps the later Dylan's lyrical strategy is just another (and quite effective) twist of the joker's hand.

Anyway, as shown, the invocatory pattern of some of Dylan's later songs not only demonstrates a multi-layered sense and a multi-directed meaning, but the songs seem to be outright shattered and sometimes even confused on the level of both description (sense) and interpretation (meaning). This is of course no verdict on lyrical quality, but is indeed a remarkable development of what took place in the gospel songs. A significant feature 
of some of these is the doubly directed invocation, which is easily discernable, and by extension this duality is making itself present in the speaker as well, which at times might be somewhat harder to detect.

To be more precise, the dual invocation in (some of) the gospel songs is not just a feature appearing on the level of interpretation (as is the case with the multi-layered addressees of most earlier Dylan songs), but presents itself on the level of description. The dual invocation is inseparable from the words's sense, while the duality of the speaker in many cases is reached only on the level of interpretation.

Furthermore, on the level of meaning the duality of both addressee and speaker relates to most gospel songs by way of eschatological extension: They all address both the listeners and the Trinity, unless one would wish to say that they are all both addressed to and being spoken from the point of view of the Holy Spirit. If so, the difference between description and interpretation becomes obsolete.

\section{Prophet with no creed}

Not surprisingly Dylan has been called a prophet. He has indeed a prophet's attitude, mostly of a contemplative and brooding sort, but fairly often a raging one as well. But all in all, he isn't a prophet with a creed. The closest we get to his basic credo is by acknowledging his enduring insistence on evil being inherent in man, and his distrust in human effort when dealing with high spiritual matters and how they both affect and probably will shatter the world as we today think we know it.

\section{Literature}

Webb, S. H. (2006). Dylan Redeemed. From Highway 61 to Saved. New York:

Continuum.

\section{Author description}

Erling Aadland has published a number of books on poetry and literary theory, among them books about Bob Dylan and Leonard Cohen. 
Latest monograph: The world of Literature, an Examination of Literature's Antinomies, Vidarforlaget: Oslo, 2019. Book about Dylan: "And the Moon Is High", Attempting to Read Bob Dylan, Ariadne: Bergen, 1998. A number of essays on Dylan, including: "Work, Performance and Performancework", Bøygen 2/2007; "We are not there (1967)", Agora 1-2/2007; "One Big Prison Yard", on (in)justice in some Dylan-songs", Bøygen 3/2008; "Dylan and Love", in: Bob Dylan, mannen, myten og musikken, Dreyer: Oslo, 2011; "He Got the Skills and He Got the Guts, Bob Dylan's Alternating Interaction with the Blues", Agora 1-2/2013.

\section{Forfatteromtale}

Erling Aadland har gitt ut mange bøker om lyrikk og litteraturteori, bl.a. om sanglyrikerne Bob Dylan og Leonard Cohen. Siste monografi: Litteraturens verden, en undersøkelse av litteraturens antinomier, Vidarforlaget: Oslo, 2019. Bok om Dylan: "And the Moon Is High", noen forsøk på å lese Bob Dylan, Ariadne: Bergen, 1998. En rekke artikler om Dylan, bl.a.: "Verk, fremføring og fremføringsverk", Bøygen 2/2007; "Vi er ikke der (1967)", Agora 1-2/2007; "'One Big Prison Yard'», om rett og urett i noen Dylan-sanger», Bøygen 3/20o8; "Dylan og kjærligheten", i: Bob Dylan, mannen, myten og musikken, Dreyer: Oslo, 2011; "He Got the Skills and He Got the Guts, Bob Dylans omskiftelige forhold til blues», Agora 1-2/2013. 


\title{
When the Wind is the Answer: The Use of Bob Dylan Songs in Worship Services in Protestant Churches
}

\author{
Pål Ketil Botvar \\ Professor i religionssosiologi, Universitetet i Agder, Norge \\ Professor of Sociology of Religion, University of Agder, Norway
}

\begin{abstract}
The songs of Bob Dylan are often used in the worship services of Protestant, and especially Lutheran, churches in Scandinavia. Since the mid-1990s more than 100 so-called Dylan masses have been celebrated in Norway alone. This can be explained partly by the fact that Dylan has been recognized as a major artist in all sections of society, and partly by the fact that the national Lutheran churches have accepted popular music as a natural part of their worship. In this article, I look more closely at the reasons behind the use of Bob Dylan's music in worship in Scandinavia and examine the discussion around this that has been going on within church communities. My empirical basis consists of interviews with ten ministers and church musicians. The material shows that different types of argumentation are used with regard to the use of Dylan's music in the church, and that this is related to the respondent's approach to popular culture in general and the way in which they regard the worship service.
\end{abstract}

Keywords: worship service, Dylan mass, Protestant church, liturgy, Niebuhr

Sammendrag: Sangene til Bob Dylan brukes ofte i gudstjenestene til protestantiske, og spesielt lutherske, kirker i Skandinavia. Siden midten av 1990-tallet har mer enn 100 såkalte Dylan-messer blitt gjennomført bare i Norge. Dette har å gjøre med at Bob Dylan er blitt anerkjent som en stor kunstner i alle deler av samfunnet og at de nasjonale lutherske kirkene har akseptert populær musikk som en naturlig del av gudstjenesten. I denne artikkelen ser jeg nærmere på bakgrunnen for at Bob Dylans musikk blir brukt i kirken og tar for meg diskursen innad i kirkene. Det empiriske grunnlaget er intervjuer med ti prester og kirkemusikere. Materialet viser at det ligger ulik type argumentasjon til grunn for bruken av Dylans musikk i kirken, og at

Citation of this chapter: Botvar, P. K. (2019). When the Wind is the Answer: The Use of Bob Dylan Songs in Worship Services in Protestant Churches. In R. W. Kvalvaag \& G. Winje (Eds.), A God of Time and Space: New Perspectives on Bob Dylan and Religion (p. 119-140). Oslo: Cappelen Damm Akademisk. https://doi. org/10.23865/noasp.74.ch4

Lisens: CC BY 4.0 
dette henger sammen med informantens tilnærming til populærkultur generelt og måten de betrakter gudstjenesten på.

Stikkord: gudstjeneste, Dylan-messe, protestantisk kirke, liturgi, Niebuhr

\section{Introduction}

Each year about 10 Protestant churches in Norway use Bob Dylan songs in their services. In some cases, Dylan's lyrics are an integrated part of the liturgy. Since the mid-199os, the so-called Dylan Mass has been used in more than 100 churches across the country, mainly in evangelical Lutheran ones. The frequent use of the Dylan mass nowadays is a paradox, since Dylan's intense Christian phase dates to the years 1979-81. The popularity of the Dylan mass thus has more to do with the churches' changing attitudes towards popular culture than with Dylan's relation to the Christian faith.

The Dylan mass is not an exceptional example of the use of contemporary popular music in Protestant churches. Johnny Cash masses, Elvis masses, and $\mathrm{U}_{2}$ masses have also been used recently in Norwegian churches. In some cases, even dance band and heavy metal masses have been performed. ${ }^{1}$

Music style is not the only aspect of church services that has changed over time - song lyrics have also changed. During the 1970 and 8 os popular songs had to include a Christian message in order to be accepted for use in church services. There have been intense discussions in clerical circles about what kind of song lyrics could be accepted. During the last 20-30 years there has been a gradual change, towards accepting that songs without any clear connection to the Christian message may also be used in worship.

Most of the songs used in the churches have lyrics that can be related to the Christian message. When it comes to Dylan songs, it is not always easy to grasp their meaning. A song can often be interpreted in different ways. This means that quite a few Dylan songs can be seen by some as having a

1 https://www.nrk.no/trondelag/heavyrock-gudstjeneste-i-selbu-1.7305233, viewed May 6, 2019. 
Christian message and by others as being regular love songs. This makes it both easy and difficult to use Dylan songs in a church setting.

Because of his Jewish background Bob Dylan was not regarded a Christian during the 1960s and early 1970s, even though his album John Wesley Harding (1968) was full of biblical references and allusions. Earlier, Dylan had already used biblical imagery in songs like "When the Ship Comes In" (1963) and "I Shall Be Released" (1967). Dylan's relation to the Christian faith changed in the late 1970s. In 1978, he had a conversion experience and became a member of the charismatic-evangelical Vineyard fellowship. His "born-again period" resulted in three gospel albums: Slow Train Coming, Saved and Shot of Love. Dylan's conversion led Christians to embrace him.

During the 1980 s and 1990 s Dylan continued to sing his overtly Christian songs. He played "Gotta Serve Somebody" from his Christian album trilogy as recently as spring 2019, on his tour in Europe. Even if Dylan's own songs from the 1990 and 2000 s are not explicitly Christian, biblical allusions have continued to constitute a substantial part of his lyrics. Today, many Christians still look on Bob Dylan as a true believer. But the question remains: why were Protestant churches reluctant to include Dylan songs in worship for such a long time, while nowadays they are so eager to conduct Dylan masses?

The way Dylan songs are used in church varies a lot. In this article, I will look at the way churches are using Dylan's music in services. How to explain the diverse types of use? Does it have anything to do with the theological positions of the particular denomination or the views of the local ministers and church musicians? Are there theological differences between free churches and established churches on this matter?

\section{Music in Church}

The issue of church music and worship styles has been a sensitive question that has divided the Christian Church for centuries. Some consider older church music to be sacred, and more recent music to be close to blasphemy. Others view older music as outdated and consider more recent music to be a gift from God. 
In the history of the Church, music has been closely connected to liturgy that is the fixed element of a worship service. ${ }^{2}$ Over the centuries, liturgies became so complex that only trained ministers and musicians could follow them, while lay people remained passive observers. The split between Roman Catholic and Protestant Churches was partly due to disagreement about the language to be used in the liturgy and the hymns. The 16 th century Reformation was a move to rekindle worship service so that the whole congregation could take part.

The Catholic Church is, today, still reluctant to introduce popular music into church services. Different popes have had different views on popular music. In 1997 the late pope John Paul II promoted a rock concert at the 23rd Italian Eucharistic Congress in Bologna. Among other artists, Bob Dylan was invited to the event. He performed three songs: "Knockin' on Heaven's Door", “A Hard Rain's Gonna Fall” and "Forever Young”. After the concert the pope shook hands with Dylan and gave a short sermon based on another Dylan song, "Blowin' in the Wind". To the young audience he said:

On the road of music this evening, Jesus met you. A representative of yours said on your behalf that the answer is blowing in the wind. Yes, it is true. On the wind there is the voice and breath of the Holy Spirit. You asked me: how many roads must a man walk down before you can call him a man? I answer you: just one. One only. It is the road of a man. And this is Jesus Christ, who said 'I am the way.' ${ }^{3}$

John Paul's successor, pope Benedict XVI (Joseph Alois Ratzinger), was, on the other hand, known to have a strong dislike of popular music. In one of his books, he reveals that he tried to stop the whole Bologna concert from taking place because he regarded Bob Dylan as a kind of "prophet" whose beliefs were at odds with the Roman Catholic Church. In his book Spirit of the Liturgy (2000) Ratzinger warns against the inclusion of popular music in the Mass.

\footnotetext{
2 The Greek meaning of liturgy is "public work".

3 https://www.telegraph.co.uk/news/worldnews/1544924/Pope-tried-to-stop-concert-by-BobDylan.html
} 
And although Ratzinger's views are not representative for all Catholics it is fair to say that the Catholic Church has adopted a conservative stance on these matters. Protestant Churches, on the other hand, have generally had a more inclusive view on the use of "secular music" in worship. However, within Protestant Churches, the use of music has from time to time been a source of disagreement and conflict, not least within the Low Church movement. The Church of Norway, for example, consists of about 1200 congregations with their own church buildings. Within this established Church, one finds both High Church and Low Church congregations. The former are mostly associated with cathedrals in the larger cities and the latter with parishes situated in the countryside.

In a church service Christians gather together for an intimate communion with the Lord. People speak to Him in prayer, praise and thanksgiving. The Lord comes to the people, speaks to them and blesses them through His Word and Sacrament. The worship service is seen by Christians as a foretaste of the heavenly life to come. The liturgical tradition is the starting point for all local forms of worship. A regular mass includes the following elements: An opening Hymn of praise/The Trinitarian Invocation/Confession of Sins and Absolution/The Introit/The Kyrie (an expression of the emptiness without God)/The Gloria (thanksgiving)/ The Salutation/The Collect prayer/The Epistle (reading from the New Testament)/The offertory (confession)/ The offering/Prayers/The sacrament (the Holy Communion)/The Sanctus/The Lord's Prayer/The Words of Institution/The Distribution, when kneel before the altar and receive the sacrament/Communion hymn/The Thanksgiving/Salutation/Closing Hymn/Silent Prayer.

The two main elements in Christian worship are the Word (part II), which relates back to synagogue worship, and the Holy Communion (part III), which relates to Jesus's last supper with the disciples. The order of the worship has developed around these two elements. They are introduced by The Gathering (part I) that points in the direction of the Word, and rounded off by the Sending (part V) that leads us from the table of communion out into service in the world. In the middle of the service, as a bridge between the Word and the Holy Communion, we find prayers and intercessions (part IV) for the church and the world. 


\section{Previous research of the use of popular music in protestant churches}

As mentioned above, there have been significant changes in the use of music styles in Norwegian churches in recent years. Parallel with these changes, sociologically informed research projects have been carried out. One of them is the project, Liturgy in motion (Balsnes, 2017; Balsnes \& Mosveen, 2016). According to Balsnes (2017, p. 36) modern popular music is the kind of music that has increased most in church services during the last 30 years. The same goes for music performed in church concerts. What is new is that liturgical music itself in the Church of Norway is now strongly influenced by popular music.

Since 2003 the Church of Norway has been implementing a reform in its worship service. Changes to liturgical music are part of this reform. During the reform period the congregations were able to choose freely among traditional Church music and various sorts of contemporary church music. According to a recent study, about one third of the congregations chose popular or contemporary liturgical music for their services, while two thirds continued to use traditional liturgical music (Balsnes \& Mostøl, 2016). Those congregations willing to reform the liturgical music share certain characteristics that separate them from congregations that hold onto traditional music styles. The study distinguished between High Church and Low Church congregations. Those congregations that chose contemporary music in their services more often than others had a Low Church orientation, meaning that they were liberal when it comes to form and style, and emphasized the idea of the music being relevant for the people and close to what they usually listen to. This means that the choice of liturgical music is a good indicator of the spiritual life of the congregation. The High Church cathedral congregations, on the other hand, leaned towards traditional liturgical music (Balsnes, 2017, p. 207).

Since 2012 every congregation in the Church of Norway has been able to choose its own liturgical music freely. In this situation about one third of the congregations have chosen popular or contemporary music for use in services, while the other two thirds have chosen more traditional types of liturgical music (Balnes \& Mostøl, 2016). The result is that what was not 
comme il faut as music for use in church only a few years back is now officially sanctioned by the church leadership. Here, too, the kind of choice made reflects, at least to some extent, a congregation's spiritual culture. The same influence from contemporary music can be seen in the hymn book (Balsnes, 2017, p. 48).

Another relevant Norwegian research project is RESEP - "Religion as aestheticizing practice". This project has looked at the use of music in different types of Christian congregation in Norway over time. The main hypothesis of the project is that dogmatic and cognitive dimensions of religion are giving way to more sensual, emotional, narrative, and thus aesthetic aspects.

In the more than 20 empirical subprojects evidence for a shift away from dogma and correct teaching towards more emphasis on feelings and aesthetics occur. Many of the research projects focused on the use of music within churches and prayer houses in Norway. Contemporary music has for a long time been accepted in Lutheran free churches and in low church movements in Norway. During recent years this kind of music has gradually found its place also within Church of Norway congregations, that is the former state church. Even if a broad process of aestheticization is taking place in the churches not least within the field of musical expressions tensions between cognitive and dogmatic and aesthetical approaches towards religion is still present (Repstad \& Trysnes, 2013).

The popular tradition of Christmas church concerts has probably paved the way for the use of secular music in church. In Norway and the other Scandinavian countries popular musical artists use churches in Advent to present various kinds of Christmas music. Secular songs are often combined with Christian songs during these concerts (Repstad \& Trysnes, 2013). The artists' relation to Christianity also varies, but even if only a few call themselves true Christians most have a positive attitude towards the Christian faith. Christmas concerts can be seen as a way of building bridges between worship in church and general culture (Repstad \& Trysnes 2013).

Little has been written from an academic point of view about the use of Dylan's songs in churches in the Nordic countries. However, a limited study of the use of Dylan's songs in church was included in the RESEP project (Botvar, 2013). One of the findings was that since his conversion to the 
Christian faith in the late ' 70 B Bob Dylan has attracted as fans a considerable number of Christians. Those fans that themselves are Christians also tend to look on Dylan as a true Christian while non-Christian fans do not see him this way. When the Dylan songs are translated into Norwegian to be used in church, the Christians elements in the lyrics are stressed.

Another scientific contribution to the discussion about Scandinavian churches and Dylan is sociologist Andreas Häger's article "Dylan Goes to Church: The Use of Bob Dylan's Music in Protestant Churches" (Häger, 2018). In his article Häger compares three Dylan masses, two from Sweden and one from the US. In the article he discusses how the Dylan masses contribute to the construction of popular beliefs about Bob Dylan's relation to religion. The main question in Häger's article is how the two cultural spheres of church and rock music relate and how they can be combined. Some research, then, has been conducted into the use of Dylan's music in Scandinavian churches. It is also important to bear in mind that this phenomenon is part of the growing trend of using popular and secular music in church. This is another reason why it deserves even more attention and study from church sociology than it is enjoying at the moment.

\section{Data material and research questions}

My empirical material consists of programs and text from nine Dylan masses in Norway and Sweden, observations from four masses I myself have attended and interviews with eleven theologians/vicars or church musicians. Five of the interviews were conducted face-to-face, two by phone and three by mail. Out of the interviews, eight were with vicars or theologians who had worked as vicars and two were with church musicians.

The documents were leaflets and programs gathered from Dylan masses, seven Norwegian ones and two from Sweden. Eight out of nine masses were conducted in Lutheran majority churches and one in a Lutheran free church. In a few cases, I have access to all the spoken words during the mass, including the sermons. In addition, I have some limited data about a couple of other Dylan masses conducted in Scandinavia. I will focus mainly on the masses about which I have comprehensive data and on the interviews with church employees. 
In the remaining part of this article, I will focus on three questions. How are Dylan songs integrated in the mass structure? What are the motivations that pastors and church musicians have for using Dylan's music and lyrics in a sermon? What are the main arguments for and against such use? The first question will be discussed on the basis of data about the structure and organization of the Dylan masses and the two last based on qualitative interviews. ${ }^{4}$

\section{Dylan as liturgy}

The first Dylan mass in Norway took place in 1996 in a former cinema that had been taken over by the Lutheran Free Church in Oslo. The songs used in the mass were all translated into Norwegian by a team of pastors with relations to both the Lutheran Free Church and the Church of Norway (the former state church). The songs were carefully selected to fit with certain parts of the liturgy, and the whole Dylan mass functioned very well alongside the liturgy. Later, this first version became a model for future masses. Many congregations have used at least parts of it in their own Dylan masses. One of the most distinct differences between the masses is between those that use the original songs in English and those that use versions translated into Norwegian. Free Church congregations tend to use Norwegian translations of the songs while the Church of Norway congregations usually adhere to the original English version. This could of course have something to do with differences in the audiences, but it probably also reflects ideological or theological differences. How clearly does the message have to be presented? In addition, how far can the church go in adapting a song lyric to the message of the church?

Since the same persons are often involved, there is not always a significant difference between a Dylan mass used in a Free Church and in a Church of Norway congregation. The Free Church pastor Sven Aasmundtveit has been active in many of the Dylan masses. Together with two colleagues, he has translated most of the Dylan songs that are used in

4 Altogether 11 persons were interviewed, 8 pastors and 3 church musicians. 5 of the pastors were interviewed face to face. The rest of the interviews were shorter and done by mail or telephone. 
the standard Dylan mass in Norway. The mass that was developed by the team of ministers in the mid-1990s includes songs from different phases in Dylan's career, even if the majority are taken from his Christian period (1979-1981). Most of the songs selected for the mass have a distinct Christian message while others connect to Christianity in a subtler way.

I have focused on Dylan masses that have integrated the songs into the liturgy of the mass. Leaflets that show the lyrics and where the songs are sequenced in the liturgy accompanied all those I am referring to. Not all masses included all the traditional liturgical elements. Two out of nine, for example, did not include communion. This makes it disputable if they should be called a mass at all - perhaps "concert" is nearer the mark? However, these two masses resembled a traditional mass in that they had a big church choir and used classical, acoustic instruments. From some of the informants I received detailed descriptions of the mass and, in some cases, I also received a transcript of the sermon given by the minister.

Table 1 shows the songs performed at ten Dylan masses in Lutheran cathedrals and free churches in Norway and Sweden during the period 1996-2017 and their place in the liturgy.

The song "Ring them bells" (1989) tends to be used as opening hymn in a Dylan mass. The song was composed after Dylan's evangelical phase but has an immediate relevance for a church service. The same goes for songs like "Knockin' on Heaven's Door" and "I shall be Released", both being released before Dylan's conversion to Christianity. "The Times they are a-Changin'”, one of Dylan's first hits, has been used as an opener in those Dylan masses that adopted the model worked out in the free church.5

Most of the songs used in the Dylan mass include references to the Bible and are thus related to the Christian message. This is most clearly the case for the songs taken from the three gospel albums. Of special interest are the inclusions of songs that are normally not seen as proclaiming a Christian message. Songs taken from post-gospel albums include "License to Kill” (1983), "Sweetheart Like You” (1983), "Emotionally Yours" (1985), "What Good am I?" (1989), "Make You Feel My Love" (1997) and "Not 


\begin{tabular}{|c|c|c|c|c|}
\hline $\begin{array}{l}\text { The Elements of the } \\
\text { Liturgy }\end{array}$ & $\begin{array}{l}\text { Oslo 1996, } \\
\text { Larvik 1997 } \\
\text { (songs in } \\
\text { Norwegian) }\end{array}$ & $\begin{array}{l}\text { Oslo 2011, } \\
\text { Moss 2012 } \\
\text { (Songs in } \\
\text { English) }\end{array}$ & $\begin{array}{l}\text { Lidar church } \\
2013,2016, \\
2017 \\
\text { (most songs in } \\
\text { English) }\end{array}$ & $\begin{array}{l}\text { Malmö 2013? } \\
\text { Västerås } 2016 \\
\text { (songs both in } \\
\text { Swedish and } \\
\text { English) }\end{array}$ \\
\hline \multicolumn{5}{|l|}{ Part I Gathering } \\
\hline Opening hymn & $\begin{array}{l}\text { The Times They } \\
\text { Are A-Changin' } \\
\text { (1963) }\end{array}$ & $\begin{array}{l}\text { Ring Them Bells } \\
\text { (1989) }\end{array}$ & $\begin{array}{l}\text { Ring Them Bells } \\
\text { (1989) }\end{array}$ & $\begin{array}{l}\text { Shelter from the } \\
\text { Storm (1974) }\end{array}$ \\
\hline Introitus & $\begin{array}{l}\text { Man Gave } \\
\text { Names to All the } \\
\text { Animals (1979) }\end{array}$ & & $\begin{array}{l}\text { Knockin' on } \\
\text { Heaven's Door } \\
(1973)\end{array}$ & $\begin{array}{l}\text { Knockin' on } \\
\text { Heaven's Door } \\
\text { (1973) }\end{array}$ \\
\hline Confession of sin & $\begin{array}{l}\text { A Hard Rain's } \\
\text { A-Gonna Fall } \\
(1962)\end{array}$ & & $\begin{array}{l}\text { I Threw it All } \\
\text { Away (1969) }\end{array}$ & $\begin{array}{l}\text { Emotionally } \\
\text { Yours (1985) }\end{array}$ \\
\hline Kyrie & $\begin{array}{l}\text { License to Kill } \\
\text { (1983) }\end{array}$ & $\begin{array}{l}\text { Pressing On } \\
(1980)\end{array}$ & $\begin{array}{l}\text { Lay Down Your } \\
\text { Weary Tune } \\
\text { (1964) }\end{array}$ & \\
\hline Absolution & $\begin{array}{l}\text { I Shall Be } \\
\text { Released (1967) }\end{array}$ & & & $\begin{array}{l}\text { I Shall Be } \\
\text { Released (1967) }\end{array}$ \\
\hline Gloria & $\begin{array}{l}\text { Knockin' on } \\
\text { Heaven's Door } \\
(1973)\end{array}$ & $\begin{array}{l}\text { Father of Night } \\
\text { (1970) }\end{array}$ & $\begin{array}{l}\text { New Morning } \\
(1970)\end{array}$ & \\
\hline Credo & $\begin{array}{l}\text { I Believe in You } \\
\text { (1997) }\end{array}$ & $\begin{array}{l}\text { I Believe in You } \\
\text { (1979) }\end{array}$ & $\begin{array}{l}\text { I Believe in You } \\
\text { (1979) }\end{array}$ & \\
\hline \multicolumn{5}{|l|}{$\begin{array}{l}\text { Part II } \\
\text { The Word }\end{array}$} \\
\hline Reading & $\begin{array}{l}\text { When You } \\
\text { Gonna Wake } \\
\text { Up? (1979) }\end{array}$ & & $\begin{array}{l}\text { I Shall Be } \\
\text { Released (1967) }\end{array}$ & $\begin{array}{l}\text { Ring Them Bells } \\
\text { (1989) }\end{array}$ \\
\hline \multicolumn{5}{|l|}{ Part III Intercession } \\
\hline Offertorium & $\begin{array}{l}\text { Every Grain of } \\
\text { Sand (1981) }\end{array}$ & $\begin{array}{l}\text { Every Grain of } \\
\text { Sand (1981) }\end{array}$ & $\begin{array}{l}\text { Every Grain of } \\
\text { Sand (1981) }\end{array}$ & \\
\hline \multicolumn{5}{|l|}{ Agnus Dei } \\
\hline \multicolumn{5}{|l|}{ Part IV Communion } \\
\hline Sanctus & $\begin{array}{l}\text { Saving Grace } \\
(1980)\end{array}$ & \begin{tabular}{|l|} 
In the Garden \\
(1979)/ When He \\
Returns (1979)
\end{tabular} & $\begin{array}{l}\text { Make You Feel } \\
\text { My Love (1997) }\end{array}$ & $\begin{array}{l}\text { Lord, Protect My } \\
\text { Child (1983) }\end{array}$ \\
\hline Agnus Dei & & Solid Rock (1980) & & $\begin{array}{l}\text { Make You Feel } \\
\text { My Love (1997) }\end{array}$ \\
\hline \multicolumn{5}{|l|}{ Part V Sending } \\
\hline $\begin{array}{l}\text { The Blessing/ } \\
\text { Benediction }\end{array}$ & $\begin{array}{l}\text { Forever Young } \\
(1974)\end{array}$ & & $\begin{array}{l}\text { Forever Young } \\
(1974)\end{array}$ & $\begin{array}{l}\text { Mr. Tambourine } \\
\text { Man (1965) }\end{array}$ \\
\hline Postlude & $\begin{array}{l}\text { All Along the } \\
\text { Watchtower } \\
(1968)\end{array}$ & & $\begin{array}{l}\text { Love Minus } \\
\text { Zero/No Limit } \\
\text { (1965?) }\end{array}$ & $\begin{array}{l}\text { Blowin' In the } \\
\text { Wind (1962) }\end{array}$ \\
\hline
\end{tabular}

Table 1. The structure of the Dylan mass in various Lutheran congregations in Norway and Sweden, 1996-2017. 
Dark Yet" (1997). These songs do not include an unequivocal religious message. Nevertheless, they may be interpreted as having some relation to Christian ideas. This relationship to the Christian message is however often reinforced when the song is translated into Norwegian with the purpose of being used in church. When translated into local language it becomes easier for ordinary churchgoers to see the relevance that the song may have in a Christian context. "Forever Young", the song Dylan wrote to his son Jacob, is often used as a Benediction at the end of the service. In some cases, well-known songs like "Blowin' in the Wind" (1963) and "All Along the Watchtower" (1967) could also be used as the final song during silent prayers.

What distinguishes the masses - apart from some variation in song selection and the language the songs are sung in - is to what extent the songs are selected to match the liturgical elements.

The High Church congregations (such as those in cathedrals in larger cities) tend to prefer a Dylan mass that resembles a church concert. In such a mass, there is no communion and no sing-along. On the other hand, the High Church masses follow strictly the traditional elements in the liturgy and only use songs from Dylan's gospel period. In some ways, the High Church Dylan mass is most in line with the traditional Christian mass from before the Reformation and its introduction of local language and popular music in churches.

From time to time Dylan as a person is also a theme in the sermons. In one of them Dylan's conversion to Christianity was highlighted. However, it was not made clear in this mass that his evangelical phase had ended (in 1981) and that Dylan's life stance later had become more multifaceted.

In a sermon held during another of these masses Dylan's life after the gospel phase is commented upon: "Many of you may think that Dylan's evangelical phase was rather bizarre (...) Later Dylan became introspective and uncertain about his own viewpoints. Christian ethics always has our neighbour as its focus. Our sin is just to be concerned with ourselves. This implies that we turn away from both God and our neighbour: 'If I shut myself off so I can't hear you cry / What Good am I?"” ("What good am I?" is the title of a Dylan song from 1989). 
Unlike some of the other sermons preached in these masses, this one does not fail to refer to songs from the time after Dylan's evangelical years, when he appears more uncertain of his religious views. The sermon makes use of a song from 1989 to make the point that the greatest of all sins is to turn away from Thy neighbour.

The Dylan masses for which I have data can be divided into three categories:

a) The rock mass: characterized by original lyrics in English, sparse use of liturgy, not necessarily including communion, more like a concert than a mass. Electric instruments. Usually not on Sunday morning, non-regular church audience.

b) The High Church mass: often classical instruments, use of the standard liturgy of the mass, songs are performed in English, not always including communion, no sing-along.

c) The Low Church mass (both in Lutheran Free Church and Church of Norway congregations): often acoustic instruments, active use of the ordinary church staff, songs/text integrated in liturgy, communion, text often translated into Norwegian/Swedish, held on Sunday morning.

\section{Dylan mass - the discourse}

Academic discussions about theology and popular culture often refer to the theory or model put forward by sociologist and theologian H. Richard Niebuhr. In his book Christ and Culture (1951) he formulates a theoretical model on how different Christian groups approach cultural expressions.

Some decades later the scholar Gordon Lynch (2005) still makes use of Niebuhr's typology when he seeks an understanding of the relationship between theology and (popular) culture. Even if the theological differences between Christian groups may have weakened after 50 years of ecumenical cooperation, the typology is still useful for empirical analyses of the relationship between Christian theology and popular culture. Niebuhr identifies five different positions Christians can take when they want to understand culture: 
1. Christ against Culture. This position is characterized by a clear opposition between the truth embodied in Christ and particular forms of contemporary culture. Christians adopting this approach must choose between following Christ or engaging in contemporary culture. This is a view often taken by sect-like Christian groups.

2. The Christ of Culture. This is the opposite position to the first approach and adopts a far more positive view of the potential of human culture. Certain forms of culture are seen as embodying Christ's truth. As examples of these positions, Niebuhr points to various forms of Protestant liberalism.

3. Christ above Culture. This third approach interprets the products of human culture as gifts of God. Human culture may have positive elements within it and may point people towards Christ. This approach is associated with "creation-centered" Catholic theology, which places strong emphasis on the possibility of receiving revelation in the context of day-to-day life.

4. Christ and culture in paradox. In this approach Christ and culture are seen as separate and autonomous parts of human life. The approach is exemplified in Luther's belief that the state demanded respect and obedience. Human culture, despite its flaws, must be tolerated and worked within.

5. Christ the transformer of culture. This final approach shares the belief of the first and fourth of these approaches in the fundamentally flawed nature of human culture. But unlike the Christ against culture model, it advocates engagement with, rather than withdrawal from, culture. Contemporary forms of culture should be critiqued and challenged and ultimately transformed in order to reflect the truth of Christ.

According to Lynch these five positions differ on the question of whether human nature can be seen as a mediator of goodness and truth. Other questions relate to how truth is revealed in us. Some of the perspectives (3-5) allow for a constructive dialogue between theological norms and popular culture, while perspectives 1-2 do not (Lynch, 2005, p. 101). 
Most of my informants were enthusiastic about the idea of using Dylan in a church service. This comes as no surprise since most had already been involved in such masses and could in some cases be described as "Dylan fans" themselves, even if they refused to apply this label to themselves. Sometimes their arguments were presented in biblical language, like the informant who states that "Dylan is a worthy successor of the prophets of the Old Testament, like Jeremiah".

Still, within the group of 11 respondents I found different positions on the use of popular culture in church worship. In the following I will discuss how the respondents from both the Lutheran majority church and from Lutheran free churches relate to the model of Niebuhr and what arguments they use to legitimize their views. I will concentrate on the views of 5 ministers since they were the ones I interviewed most extensively and therefore it is possible to place their views precisely in the model proposed by Niebuhr.

None of my informants adheres to the approach called Christ against culture. The former pope Joseph Ratzinger, however, as mentioned earlier in this article, clearly represents this approach. In his view popular culture is fundamentally compromised and beyond redemption. This makes any dialogue between theological norms and popular culture impossible.

At the other extreme, we find the perspective Christ of culture, which sees all human forms as potentially representing the truth of Christ. One of the theologians, a former minister, I interviewed represents this position. We can call him Albert (6o years + ). He practiced as a minister for many years but is now in Academia. He is very positive towards the use of Dylan material in church, including in the mass. One of his arguments is that Bob Dylan is well-known and may have an appeal to those members who seldom go to church apart from attending rituals such as baptism, confirmation, weddings and burials. According to Albert the American gospel music that is often used in sing-the-praise masses (lovsangsmesser) in Lutheran churches is connected to the pietistic revivalist movement, and thus alienates those church members who have no relation to this particular culture. He finds the music of Bob Dylan more inclusive. One of the main functions of music, in his view, is recognition - that people are familiar with the music and can mirror themselves in the lyrics. 
According to Albert, this can better be accomplished by popular music than by traditional hymns or psalms. Albert therefore welcomes changes in the mass based on the introduction of popular music. Contrary to some other respondents, he does not see the translation of Dylan's lyrics into Norwegian as problematic as long as the translations meet high standards of artistic quality. He mentions that $35-40$ of Dylan's songs can easily be transferred to the church hymnal preferably in Norwegian translations. One of the problems he finds with today's services is that they follow a strict scheme and do not easily accommodate a wide range of feelings. However, while Albert is open for translations of Dylan songs into Norwegian, he does not belong to the category Christ the transformer. Using translation to make the songs more suitable for a church setting is, in his view, only acceptable if the songs fulfil strict artistic requirements. He does not think this is always the case with today's Dylan masses.

Another male minister, George (50+), represents the Christ above culture category. This approach sees theological reflection as making a constructive contribution to interpreting and critiquing cultural values and practices. In certain cases, human culture is seen as a force for goodness and truth, but not always. George is critical of some elements from popular culture that are incorporated into masses in Lutheran churches. In the past he has conducted more than one Dylan mass as minister. But gradually he has changed his views about these masses. Today, he thinks that such masses are highly problematic, not because the Christian mass cannot tolerate being influenced by popular music, but because the message of the songs does not always match the framework of a mass in the Lutheran church. He now thinks that the songs should be used in their original English version and not be interpreted by the representatives of the church. George is more comfortable letting Dylan's songs speak for themselves in a church concert rather than placing them in the structure of a mass. George is very concerned about which songs should be used in a church setting. A crucial point in George's thinking is that the songs Dylan wrote during his evangelical phase (1979-81) do not match the type of Christen belief that the Church of Norway stands for. The church is far more liberal than Dylan was when he wrote these songs. George thus doesn't think that these songs should be performed in the Church of Norway today. 
Niebuhr's fourth category Christ and culture in paradox represents the classical Lutheran perspective - that is, to respect cultural expressions outside the church but not wanting to mix them with what is going on inside the church. Two of the ministers in the Church of Norway that I interviewed are leaning towards this position. Since I am studying only Lutheran churches it is a paradox that not more than two of the respondents represent this perspective. One of the ministers, Richard (40+), clearly falls into this category. Susan (50+) also leans in this direction even if she is not as easily categorized.

Richard works in the Church of Norway, mainly with young people. He is personally very fond of Bob Dylan and uses his songs to get inspiration for writing sermons. Richard admires the Dylan's songs and even states that "Dylan is touched by the hand of God". Despite this, Richard hesitates to use the songs in a mass. To him Dylan does not belong in a Lutheran church. His main argument is that this is a misuse of great artistic work. Richard cannot imagine how the songs of Dylan can be used in a service without abusing the songs or the composer in one way or another. "What would Dylan have done?" he asks rhetorically. By putting the songs into a mass, the scope of interpretation becomes limited, and the artist is placed in a setting where he does not belong. If Dylan's songs are to be used in a church setting, something he opposes, at least one should, in his view, stick to the newest songs because these are the only ones that we know Dylan stands by today. Richard calls the way Dylan has been used in the Church of Norway in the past "dishonest". A Dylan mass will, he maintains, most likely turn into a worship of Dylan and not of God. He has attended these masses himself. They leave him dissatisfied, partly because he realized that the people involved were saluting Dylan instead of God.

Susan is the other minister who is sceptical towards the Dylan mass. She sees Dylan as an important figure in contemporary culture and thinks he plays an important role in criticizing all those in power, including those in the church. Susan does not completely oppose all use of Dylan songs in a church setting. However, she thinks that it is very difficult to find the right way of doing this, and is critical towards the contemporary Dylan mass. What she fears the most is that the church should make 
Dylan less complex than he is and paint a picture of him that he himself would not feel comfortable with. At the same time, she thinks it is fair to use one or two Dylan songs in a service, but more problematic to build a complete mass around his songs. Susan is very concerned about being authentic and true to the material she herself uses in a mass. The only way to do justice to both the artist and the church would, in her opinion, be to make Dylan write a mass himself, the same way as composers like Mozart, Bach and Arvo Pärt have done before him.

The remaining approach, Christ the transformer of culture, permits an adjustment of popular culture in order to make it correspond with the message of the church. Those who subscribe to such a view think human culture needs to be transformed in order for it to be a force for goodness and truth.

One of the ministers, Johnny (6o+), falls into this category. He is a pastor in the Lutheran free church. He has been involved in Dylan masses in which the songs were translated into Norwegian. In these masses the text was printed on paper and distributed to the congregation. Johnny thinks it is important that the message comes out clearly. Even if he doesn't think the evangelical songs are among Dylan's best, he still thinks they are best suited for a mass because they have a clear Christian message. Like some of the other theologians in my material Johnny finds that many of Dylan's songs contain Christian elements. In order to make the attendees understand the underlying Christian message it is necessary, he thinks, to have the songs translated into Norwegian. As an example, he mentions the 1997 song "Make you feel my love". According to Johnny, many people do not catch the underlying Christian content of this song. In order to legitimize the use of Dylan's songs in the church services he mentions that Dylan himself plays with his own songs and even from time to time changes their wording. Johnny is, however, aware of the criticism that has been directed towards the Dylan mass from other theologians. He is not afraid that the mass would become an occasion for worshipping Dylan rather than God. Instead he argues: "it is important to bring everyday experiences into the mass. And popular culture is an important part of people's everyday life".

The remaining 6 respondents, church musicians and ministers, belong to one of the two groups Christ above culture or Christ the transformer of culture. The difference between the two has to do with the degree of 
criticism towards popular culture. Most of the informants are eager to construct new types of the mass that appeal to people that do not go often to church. It is difficult to detect second thoughts about the Dylan masses among these respondents.

Several of them argue that the church needs to be renewed in order to remain relevant for people today. The inclusion of popular music in church services is one way of doing this. Some of them also refer to a desire to draw new kinds of people to church. One of the positive side effects of the Dylan mass is that it makes it easier to reach out to those sections of the population that seldom go to church, such as middle-aged men.

"To reach out" is a key concept in the argumentation for introducing Dylan songs into church services. Another argument is that today's churchgoers often have a closer relationship to songs from mainstream pop culture than to the songs and hymns in the church hymnal. This is a persuasive argument for including well-known Dylan songs in services.

Church musicians often play an active role when it comes to choosing the music to be used in a mass. One of the church musicians states that as leader of the church choir he is always open for ways to renew the repertoire and find new songs for use in services. Apart from the Dylan mass, this musician's choir has been engaged in a U2 mass and in blues and jazz masses based on the music of popular artists. When picking artists, he always searches for content that can lift the spirit up even if it isn't an explicitly Christian song. What he is looking for is "a piece of lyric with meaning". This church musician goes on to say, "A Dylan mass can make the congregation aware of the fact that popular music sometimes contains lyrics that are just as pious as traditional hymns." Even if this respondent promotes a liberal view of popular music, he still believes there is a limit to what can be accepted in a church. To make his point clear he mentions the example of a heavy metal band of Satanists; "I would probably not let them play in my church", he says. This statement reflects a theological position: popular cultural elements should fit in with the purpose of the mass. The question that is actualized is: What is the meaning of a mass?

Another church musician argues that rap music is of no offence so long as it "promotes a positive view of life". However, the view that the mass should only correspond to positive life-affirming feelings is not 
shared by every respondent. One of the female ministers states that "the songs [of Dylan] live their own life and take on their own meanings". In the Dylan mass she recommends that the congregation should keep in touch with their feelings and do what they feel is right at any given moment: "... if this is to clap, then clap, if it is to weep, just weep", she says. Furthermore, Albert (see the interview reported above) presents the argument that the Christian mass is a place for all sorts of feelings, and not only the feelgood type.

\section{Concluding remarks}

My material has been taken from so-called Dylan masses being held in Lutheran congregations in Norway and Sweden in recent years. Even if a lot of water has passed under the bridge since the Reformation introduced popular elements in the mass, the question is still how to get lay people to participate in, and feel that they participate in, the mass. Translating songs from English to the local language is still controversial, as is the question of what kind of music should be allowed in the church.

In recent years several different types of Dylan mass have been used in Lutheran churches in Scandinavia: from the High Church mass in English with choir and orchestra to a Low Church version in Norwegian. The most commonly used mass was laid down by a group of ministers and others in the beginning of the 1990s and has remained unchanged since then. In both Norway and Sweden, we find that this popular Dylan mass is the work of a few enthusiastic ministers and church musicians.

Only two out of eleven respondents argue against the use of Bob Dylan in a Christian service. This is not because they don't find a Christian message in many Dylan songs. Their reason is the classical Lutheran one: they do not want to mix the sphere of popular culture with the sphere of the Church. By adopting a Dylan mass, the church, so their argument goes, runs the risk of limiting the art of Dylan and putting the artist in a box where he does not belong.

The remaining informants, be they ministers or church musicians, are positive towards the use of popular culture in a mass. They have no hesitation in using the songs of Bob Dylan in a church service in order to 
underline certain aspects of the Christian message or in making them fit with elements in the liturgy. Their arguments typically point in an instrumentalist direction.

The interviews have revealed that there are different views among ministers and church musicians in Lutheran Churches in Scandinavia regarding the use of elements from popular culture in worship. In addition, it is striking to find significant differences in views about the purpose of putting such elements into the mass. Some of my respondents argue that popular cultural elements should be used to strengthen the feelgood character of the mass.

By acting according to this reasoning one runs the risk not only of ignoring the content and true message of the Dylan songs themselves, but also of going against the very intention behind the Christian mass.

\section{Literature}

Balsnes A. H. (2017). Populærmusikkens vei inn i Den norske kirke. DIN: Religionsvitenskapelig tidsskrift (1), 36-6o.

Balsnes, A. H., \& Mosdøl, H. O. (2016). Menighetens soundtrack: Hvilke verdier ligger til grunn for norske menigheters valg av gudstjenestemusikk? Tidsskrift for praktisk teologi, vol. 1, 17-27.

Botvar, P. K. (2013). 'With God on our side'. Bob Dylan i norsk kirkeliv. In P. Repstad \& I. Trysnes (Eds.), Fra forsakelse til feelgood. Musikk, dans i religiøst liv. Oslo: Cappelen Damm Akademisk, 277-297.

Häger, A. (2018). Dylan Goes to Church: The Use of Bob Dylan's Music in Protestant Churches. In A. Häger, Religion and Popular Music: Artists, Fans, and Cultures. London: Bloomsbury, 167-185.

Lynch, G. (2005). Understanding Theology and Popular Culture. Oxford: Blackwell Publishing.

Løvland, A., \& Repstad, P. (2014). Playing the Sensual Card in Churches: Studying the Aestheticization of Religion. In A. McKinnon \& M. Trzebiatowska (Eds.), Sociological Theory and the Question of Religion. Farnham: Ashgate.

Niebuhr, R. (2001/1951). Christ and Culture. New York: HarperCollins Publishers.

Ratzinger, J. (2000). The Spirit of the Liturgy. San Francisco: Ignatius Press.

Ratzinger, J. (2005). The Legacy of John Paul II: Images and Memories. San Francisco: Ignatius Press.

Repstad, P., \& Trysnes, I. (2013). Fra forsakelse til feelgood. Musikk, dans i religiøst liv. Oslo: Cappelen Damm Akademisk. 


\section{Author description}

Pål Ketil Botvar gained his $\mathrm{PhD}$ in political science from the University of Oslo, 2009. He is professor in sociology of religion at the faculty of humanities and education, University of Agder, Norway. Botvar has been co-editor on Bob Dylan - mannen, myten og musikken (The man, the myth and the music), together with R. Aasgaard and R. W. Kvalvaag. He has also written two articles about Bob Dylan: "Med Bob Dylan som liturg", 2013 ("Bob Dylan as Officiant"), and "With God on Our Side. Bob Dylan i norsk kirkeliv", 2013 ("With God on Our Side. Bob Dylan in Norwegian church life").

\section{Forfatteromtale}

Pål Ketil Botvar har doktorgrad i statsvitenskap fra Universitet i Oslo, 2009. Han arbeider nå som professor i religionssosiologi ved fakultetet for humaniora og pedagogikk, Universitetet i Agder. Han har vært medredaktør på boken Bob Dylan - mannen, myten og musikken (sammen med R. Aasgaard og R. W. Kvalvaag). Botvar har også skrevet andre Dylanrelaterte artikler: «Med Bob Dylan som liturg» (2013), i Sanselig religion, A. Løvland, P. Repstad, E. S. Tønnessen (Red.). s. 84-86. Oslo: Verbum, samt «With God on Our Side’. Bob Dylan i norsk kirkeliv» (2013), i Fra forsakelse til feelgood. Musikk, sang og dans i religiøst liv, P. Repstad og I. Trysnes (Red.), s. 277-297. Oslo: Cappelen Damm. 


\title{
CHAPTER 5
}

\section{The Visual Dylan: Religious Art, Social Semiotics and Album Covers}

\author{
Geir Winje
}

Dosent, Fakultet for humaniora, idretts- og utdanningsvitenskap, Universitetet i Sørøst-Norge.

Professor, Faculty of Humanities, Sports and Educational Science, University of South-Eastern Norway.

\begin{abstract}
The essay explores the cover art on 24 studio albums released by Bob Dylan since his debut in 1962, each one with a photo of the artist on the front cover. The photos are read chronologically in accordance with a social semiotic understanding. Any text, including such elements as names, album titles, song titles and motifs, but also formal means, e.g. compositions and geometric patterns underlying the compositions, are understood as meaningful utterances in their own right, not only as illustrations for other texts. The essay also maps out some parallels between the idol as a mediated person belonging to modernity and as a premodern religious concept. A not surprising finding is that parts of early Christian icon art are continued in modern photographic portraits. However, I have not found anything indicating that traces of early religious art are more prominent on Bob Dylan's albums than on other albums.
\end{abstract}

Keywords: Bob Dylan, album covers, album art, portraits, photo, social semiotics, religious art

Sammendrag: Artikkelen undersøker omslagene på 24 studioalbum utgitt av Bob Dylan, fra debuten i 1962 til 2015. Hvert av de 24 albumene har et fotografisk portrett på forsiden av coveret. Fotografiene leses kronologisk, som en fortelling eller tegneserie, i lys av sosialsemiotisk teori. Elementer som titler og andre verbaltekster, blikkretning, innramming og komposisjon forstås som selvstendige tekster, ikke bare som illustrasjoner til andre tekster. Artikkelen sammenligner også idolet som førmoderne religiøst konsept med idolet som mediert person i det moderne. En lite overraskende konklusjon er at visse trekk ved førmoderne religiøs kunst - både formale og ikonografiske - lever videre i dagens kunst. Jeg har imidlertid ikke funnet noen indikasjoner på at religiøse elementer er mer sentrale hos Dylan enn hos andre artister.

Stikkord: Bob Dylan, LP-covere, portrett, fotografi, sosialsemiotikk, religiøs kunst

Citation of this chapter: Winje, G. (2019). The Visual Dylan: Religious Art, Social Semiotics and Album Covers. In R. W. Kvalvaag \& G. Winje (Eds.), A God of Time and Space: New Perspectives on Bob Dylan and Religion (p. 141-161). Oslo: Cappelen Damm Akademisk. https://doi.org/10.23865/noasp.74.ch5

Lisens: CC BY 4.0 


\section{Introduction}

This essay is not about Bob Dylan. It is about the cover art on some of the albums released by Dylan between 1962 and 2015. This may be understood as more or less interesting visual representation of the lyrical content and other components of the songs, but it can also be studied as artwork independent of the music. My primary interest is not to find out who designed the cover art or what they might tell us about the meaning behind it. These questions are interesting enough, but too comprehensive to handle in this essay, where I study the mediated Dylan, not the "real" Dylan. I read the album covers chronologically in order to find out how they comment on or construct a person's life and its development or growth. Both in Dylan's biography and his discography, religion has an important place. Consequently, my two research questions can be formulated like this: I. Can the photographic portraits of Dylan on the album covers be read as a narrative? II. Is there a connection between the cover art on the Dylan albums and religious art?

Before some words on earlier research, I give a brief account of the albums selected for this examination. Then I present my methods: social semiotic reading and comparison with religious art. In the most extensive part of the essay, I use these methods in a search for possible meanings conveyed by the album covers.

\section{The selected album covers}

Dylan's discography includes close to 75 albums, of which 38 are studio albums, 13 live albums and 20 compilations, depending on how they are defined and counted. To make a selection, I chose to concentrate on the studio album covers, mainly because the studio albums are the only ones that nearly always feature new songs - they surprise and challenge more than they confirm. ${ }^{1}$ To reduce the number and make comparison more

1 I am aware that Dylan is among the artists who cover their own compositions, make new songs out of old songs, and in that way surprise their listeners with unexpected interpretations. 
feasible as well as more relevant, I disregarded the 13 studio albums that do not show any photographic portraits of the artist. ${ }^{2}$

\section{Earlier research}

As far as I can see, today's Dylan research can be placed in one of two categories. Some researchers are looking for some kind of "truth"; they work like detectives, and ask questions like: What really happened? Even when these researchers analyze lyrics, they may look for "correct" interpretations. At the other end of a continuum, we find researchers who do more ambiguous readings. One of them is Andreas Häger, who in "Bob Dylan and Religion" (2009) does not try to discover whether Dylan is religious or not, or which religion he possibly adheres to. Häger looks rather at how rock artists are 'constructed' as religious figures. He refers to Janne Mäkelä and others when he proposes to study fan culture as a net with no central point instead of a result of one artistic genius: an interaction between the individual artist (his or her biography and works), the industry that produces, distributes and markets the works, the media, and the audience or fans. If so, images and album covers are as important as other parts of the net.

David Machin proposes in Analysing Popular Music: Image, Sound, Text (2010) both a social semiotic and an iconographic approach to album covers, not very different from the way I do in this essay. He also connects the analysis of album covers to theories from important semioticians and linguists like Roland Barthes and Michael Halliday.

There are lots of books about Dylan, his albums and songs. Many are illustrated, often with pictures never seen before. Bob Dylan All the Songs: The Story Behind Every Track (Margotin \& Guesdon, 2015) is - despite its 700 pages - rather typical, with a lot of facts about all the musicians, producers and others who have contributed to this life work. All the Songs differs nevertheless from most other books, in that each chapter (except

2 Self Portrait (1970), Pat Garrett and Billy the Kid (1973), Planet Waves (1974), Slow Train Coming (1979), Saved (1980), Shot of Love (1981), Knocked Out Loaded (1986), Oh Mercy (1989), Modern Times (2006), Together through Life (2009), Christmas in the Heart (2009), Fallen Angels (2016), Triplicate (2017). 
two) has a paragraph about the cover of the album that the chapter is about - usually encyclopaedical, but sometimes with an analytical twist, e.g. no. 3: The Times They Are A-Changing' (Margotin \& Guesdon, 2015, p. 84).

Magnus Bettum has written about "Bob Dylan's record covers in the light of design history" (2011). Here he uses various methods when comparing the record covers with trends categorized in decades from 1960 to 2010.

A search for "Bob Dylan Album Covers" on the Internet leads to a lot of more or less interesting sites: photographers tell their stories, readers are invited to vote on the best album cover, etc. ${ }^{3}$ The non-academic style does not hinder some brief, but to the point, analyses - for example, from Andrew Danby (see "Album covers sometimes just as powerful as his songs"4). All these books and articles have been helpful in my project.

\section{Methods}

The Greek word semeion (sign) refers to all kinds of meaningful signs, and the expression "social semiotics" refers to how signs are systematized to constitute a communication system for a certain social group (e.g. traffic signs for drivers). Since the 1990s, social semiotic approaches to all kinds of texts have increased. Images are no longer seen only as illustrations supporting verbal texts, but verbal texts and images are treated as equivalent languages or modes of expression. Albums and album covers have always been multimodal, i.e. consisting of many modes or modalities (Maagerø and Winje, 2010 - see also Jewitt, 2009 and URLs like Glossary of Multimodal Terms, multimodalityglossary.wordpress.com - read 24.08.2019).

The different modes usually expand, deepen or contrast each other. Therefore, when I isolate and analyze the cover independently of the music, I concentrate on only one part of the multimodal, total meaning. Besides, each cover may consist of several semiotic systems that do not necessarily support each other. In contrast to more hermeneutical

3 See e.g. www.stereogum.com/2040064/bob-dylan-photographers (read 03.08.2019).

4 www.chron.com/entertainment/music/article/Bob-Dylan-s-album-covers-sometimes-justas-1727586.php (read 21.07.2019). 
approaches, I am not looking for one truth or one logical conclusion. Instead of verifying or disproving the hypotheses that I construct, I try to map out different possible readings. Underwriting my approach is the recognition that both verbal and nonverbal languages are ambiguous.

After an initial review, I ended up with twelve categories of meaningful signs for the present analysis. In accordance with my understanding of social semiotic theory, both iconographic, formal and other elements can be read as texts (Kress \& van Leeuwen, 1996). The signs in the twelve categories have no fixed meanings, they partly overlap, and their relevance varies from one cover to another:

1) Black and white or color photography? (If the latter, what dominating color)?

2) Letters or not?

3) Distance from camera: close, medium or long shot?

4) Subject's gaze: staring directly at the viewer or what?

5) Oriented to the right (future) or to the left (past)?

6) Hairstyle or hat?

7) Clothing?

8) Attributes?

9) Context?

10) Frames?

11) Composition?

12) Geometric patterns underlying the composition?

I also chose three elements or features typical for religious art that seem relevant for my study (below).

\section{Some words on religious art}

It is not possible to give an overview on religious art, which I define as art referring to gods, rituals or other religious concepts and/or practices. Instead I present, very briefly, three different, but typical features in premodern religious art - all of them relevant for the analysis of the album covers (Winje, 2012). The first one applies to the very idea of depicting 
gods. In Hindu art, the gods are portrayed, either as heavenly beings or as their avatars or incarnations, while Buddhist art deals with buddhas and bodhisattvas, who are not divine in the same way, but still godlike. In Judaism and Islam we do not find any figurative portraits of God, while the main motif in Christian art is Jesus Christ. According to traditional theology, he is both human and divine, not so different from e.g. Krishna in Hindu mythology.

In a classic text from Tanakh (cf. The Old Testament), Moses receives commandments from God, among others: "You shall not make for yourself a carved image, or any likeness of anything that is in heaven above, or that is in the earth beneath, or that is in the water under the earth" (Exodus 20). However, God's distaste of figurative art is not in force when he a little later wants the Israelites to make two cherubs for the tabernacle (Exodus 25). And when Aaron, the brother of Moses, creates a golden calf as a representation of the God they have never seen (Exodus 32), the Bible text is surprisingly understanding, even if it maintains the prohibition. The worship of the calf in this story is a well-known example of idolatry (cf. idol, latin, originated from Greek, meaning an image or representation of a god, usually as an object of worship).

In the early Middle Ages, the production of icons was widespread (Tobiassen, 2012). Icon (from Greek) means "image" or "resemblance". It applies to two dimensional paintings, usually on wood, showing holy persons. They follow strict rules, each painter is anonymous and copies older paintings carefully. In the 7 th century an iconoclastic movement gained popularity in the Church, destroying a great deal of art. At a Council in 787 the views of the defenders of figurative art (iconodules) were accepted. Their arguments were based on the thoughts of John Damascene (d. ca. 750), a Syrian theologian who saw the incarnation as the main reason for the existence of icons: from the moment God was born as a human child, he was no longer invisible or without form. He was a real human and a real body, and as a real human he could be portrayed as a human. Among the oldest motifs is Christ as pantocrator (Greek: "all mighty" or "all powerful"), the most famous example is probably a mosaic in Hagia Sofia, Istanbul. In the context of the last judgment, Jesus is described as a monster in the Book of Revelation (ch. 1), but the icons show him as a 
man, fierce, but just, gazing directly at the viewer, and presenting himself by means of the halo, gestures, etc.

The formal acceptance of icons also implied a formal change from verbal to multimodal language in the Christian Church. The Council declared: "What a word communicates through hearing is what art shows silently through an image."5

An idol can be a piece of art, a good example, or a mediator between humans and supernatural beings. An idol can be a god, a semi-god, an angel, saint, prophet and more. And an idol can be a football player, politician or rock musician. Secularization is not an end to idolatry. Instead, idols do not any longer need a religious context.

To be identified, idols usually display attributes that refer to specific qualities. For example, Christian martyrs and Sikh gurus often hold the torture instrument that caused their death, John the Baptist and the Hindu God Shiva are both shabby because they live in the wilderness, and so on. This is the second, iconographic feature. The third feature is more formal, it concerns the composition and the geometric patterns behind it. When gods or holy persons are portrayed, there is a tendency to make them seem harmonic and peaceful, which is done with different forms of symmetry, balancing elements against each other, repetitions of certain patterns, the golden ratio, etc. ${ }^{6}$

\section{Analysis}

All in all, the Dylan covers have some distinctive features. One is that none of them look like any of the others. No words, not even the artist's name, are repeated with any special design to visualize that these albums belong together. The alternation between color and black-and-white also works against any kind of continuity from cover to cover. However, during the later years, photos seem to have lost some of their importance in the overall design. Among the first half of the studio album covers

5 Citation taken from a lecture by Hilarion, bishop in the Russian Orthodox Church (Theology of Icon in The Orthodox Church, 2011, mospat.ru - read 01.07.2019).

6 The golden ratio $(1,618)$ : When the proportion between the shortest line and the longest line is the same as between the longest line and the sum of the two lines. 
(1962-1978), all but three (close to $85 \%$ ) are photographic portraits, while among the last half (1979-2017), less than $50 \%$ are portraits.

1 Bob Dylan (1962)

2 The Freewheelin' Bob Dylan (1963)

3 The Times They Are A-Changin' (1964)

4 Another Side of Bob Dylan (1964)
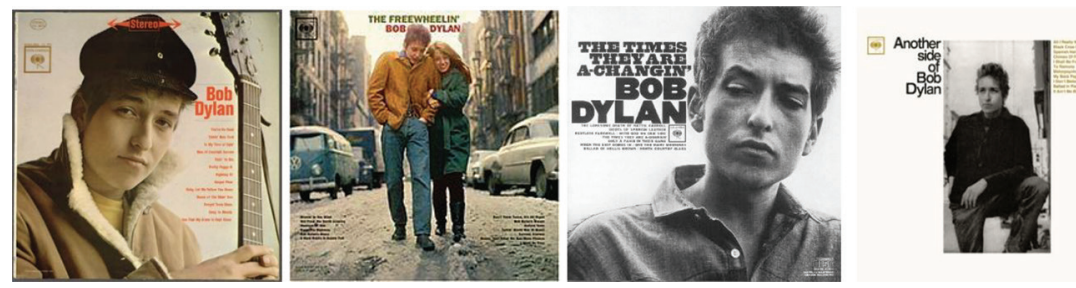

These album covers are not covered by the CC BY licence, and can not be reused.

The first four albums released by Dylan have, in my view, comparable characteristics regarding both the music, lyrics and album covers. These are also the only albums with specific song titles printed on the covers, making the images a little more like illustrations and a little less like texts on their own.

At least two of the four album covers correspond with the song titles: the young man or boy on the first cover looks like an apprentice, an impression confirmed by the fact that most of the titles refer to songs written by others. The artist on the cover of The Times They Are A-Changin' looks angry. Both his expression, the black-and-white close-up photo, the thick black letters and the song titles might be associated with revolutionary singer-songwriters like Woody Guthrie, but also Old Testament prophets like Amos, who proclaimed God's judgement on the rich. The photo on the Freewheelin' cover suggests to me (probably unintended) associations with Krishna and Radha, the supreme lovers in Hinduism. And because of the long shot in the portrait on the cover of Another Side, the expression on the artist's face is difficult to read. Another Side is also the first album cover with a framed portrait. Frames can imply limits, borders and discontinuity. An artist in a frame is not merging with his listeners, viewers or other artists. A frame can therefore be said to protect the integrity of the artist, but also to isolate him. 
The four portraits can also delineate a somewhat different process. Here Bob Dylan marks the starting point of a development that ends up with Another Side of a grown-up Bob Dylan. The sequence might suggest the artist's increasing rejection of the conventional roles of a performer of traditional folk songs (cf. Bob Dylan), love songs (cf. Freewheelin') or protest songs (cf. The Times...), while the fourth album cover represents an effort to evade these prescribed roles and categories and thereby create his own.

\section{Bringing It All Back Home (1965) \\ 6 Highway 61 Revisited (1965) \\ 7 Blonde on Blonde (1966)}

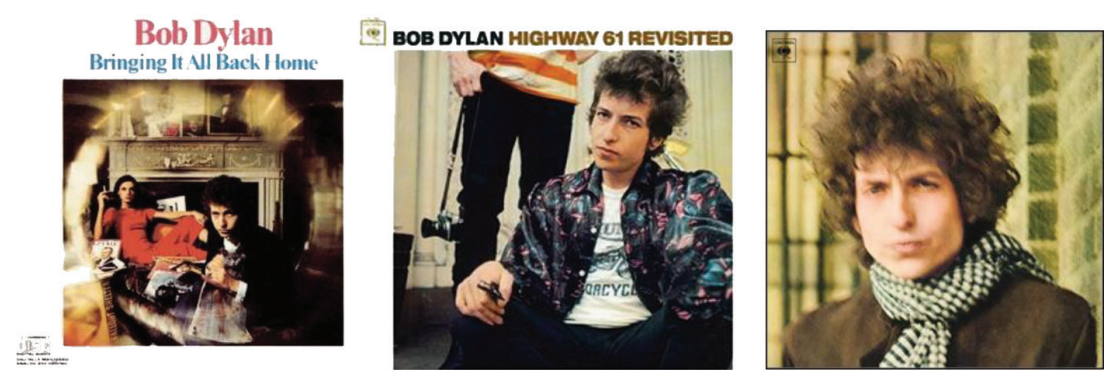

These album covers are not covered by the CC BY licence, and can not be reused.

The covers of albums 5, 6 and 7 are all in color. While nos. 5 and 6 have letters spelling "Bob Dylan" and the album title in their frames, Blonde on Blonde has no frame or writing at all. Without frames, the viewers are not held outside, and without writing, nothing is predefined. According to Machin (2010, ch. 2), when the portrayed artist's gaze addresses the viewer, it breaks out of the frame or border (here the album itself is the frame) so that the artist can communicate with the viewers/listeners instead of communicating with other people in the photos. This openness towards the audience is balanced against the artist's direct and demanding gaze. We meet this gaze in several portraits, most clearly on the covers of Bringing It All Back Home and Highway 61 Revisited. Kress and van Leeuwen claim that "if the picture is at eyelevel, then the point of view is one of equality and there is no power difference involved" (1996, p. 146). That may be right, but after working with religious art, in particular with the pantocrator (see above), it is hard to avoid seeing the power differences here, too. 
On the cover of Bringing It All Back Home, we see a lot of albums, magazines and other references to culture, art and politics. The disorderly room should maybe reflect activity, that the people who use it are active participants in a modern society. At the same time there is a calmness in the image; neither Dylan nor the lady in red are stressed, and the photograph has sculpted a certain balance between them.

On the cover of Highway 61 Revisited, the artist is apparently casually placed, but a closer look reveals a composition characterized by balance between two triangles, one "behind" each person. Dylan is the main figure here, while (the trousers of) the man with the camera (whose presence appears to be incidental) may represent journalism and the media. The sunglasses are, besides the guitar (cf. cover no. 1), the only attributes that turn up rather often. They protect the eyes against the sun, but - like the frames - they also establish a certain distance between the artist and his public.

\section{John Wesley Harding (1967) \\ 9 Nashville Skyline (1969) \\ 10 New Morning (1970)}
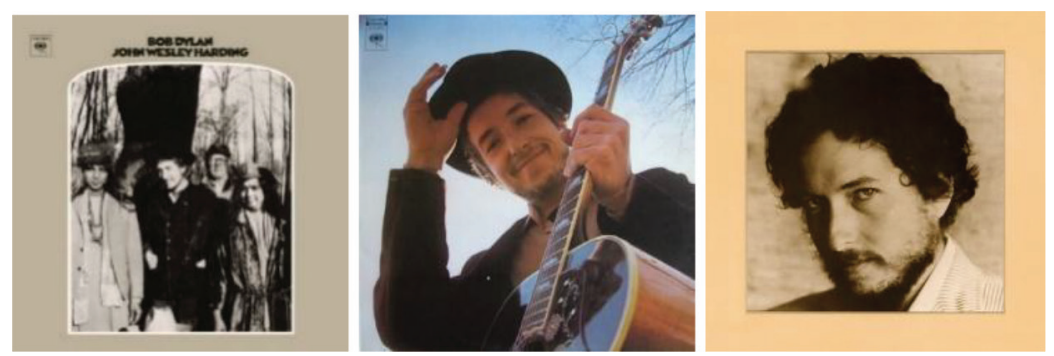

These album covers are not covered by the CC BY licence, and can not be reused.

The next album cover shows a black-and-white photo of Dylan together with three unknown persons (i.e. unknown for the ordinary listener they are actually two Indian musicians and a carpenter from Woodstock). They are all wearing hats and peering at the sun. It is difficult to recognize Dylan in this photo; he has changed both look, style and attitude. For the first time he is smiling directly at the camera. The cover has a rather dominating, grey frame, that looks like a portal, i.e. a welcome sign. The name of the artist is printed on the upper part of the frame, right over the 
title, which happens to be another name. Viewers without knowledge of John Wesley Harding, may think Dylan and Harding is a duo, like Simon and Garfunkel. Hardin (d. 1895), whose name is written without the last -g, was actually a famous gunfighter, "a friend to the poor," and the hero in a lot of traditional songs - in other words, the title proclaims that the artist once again turns to tradition.

Nashville Skyline has, like Blonde on Blonde, a cover without writing or frames. Because of the low angle, and the fact that Dylan and his guitar are rather dark, the cover seems blue. If we see the two album covers of John Wesley Harding and Nashville Skyline as one, the artist is given a double position. On the black-and-white photo he is placed among other ordinary people in the lower part of the picture, a placement associated with reality. In color he is placed in the upper part, associated with the ideal, and in this particular picture with heaven. Thus, the artist is placed both in heaven and on earth, and because of his big smile and friendly attitude, his heavenly position does not seem threatening - even if he is actually looking down on the viewers.

It is difficult to categorize the album cover of New Morning. Like Blonde on Blonde and Nashville Skyline, there is no writing on the cover, but it also differs from the two previous albums. It is in black and white, and with a frame that establishes a certain distance to the viewer. Furthermore, Dylan is not smiling. He looks straight at the camera. He looks serious, calm and thoughtful, an impression reinforced by the oblique angle of the viewer's perspective. The haircut contributes to this interpretation.

11 Dylan (1973, recorded 1969)

12 Blood on the Tracks (1975)

13 The Basement Tapes (1975, recorded 1967)

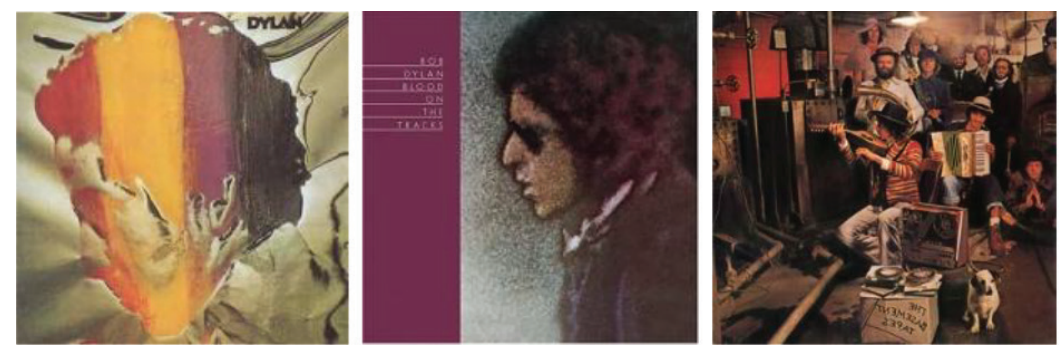

These album covers are not covered by the CC BY licence, and can not be reused. 
14 Desire (1976)

15 Street-Legal (1978)
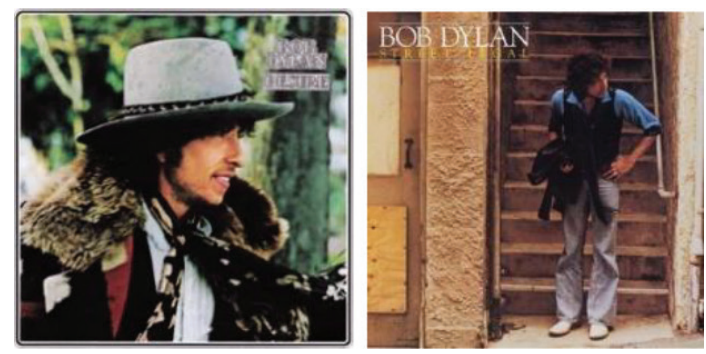

These album covers are not covered by the CC BY licence, and can not be reused.

Two of the albums issued in the 7os were actually recorded in the 6os. The bulk of Dylan was recorded five years before its release, and most of Basement Tapes eight years before its release. Therefore, pursuing a visual chronology in this period comes at the expense of musical chronology. Dylan was rather active during the 70 , when he released two compilations, three important live albums (Before the Flood, 1974, Hard Rain, 1976, and Bob Dylan at Budokan, 1979) and four important studio albums without photographic portraits on the covers: Self Portrait (1970), Pat Garrett and Billy the Kid (1973), Planet Waves (1974) and Slow Train Coming (1979).

The cover of Dylan (1973) shows the profile of Dylan, who looks like he did on the cover of New Morning (no. 10). The image is manipulated: the head is covered with four vertical fields in unnatural colors (red, yellow, purple and black), and the background looks like a piece of cloth. Is it a psychedelic banner? Or does it differ from all the other album covers just to tell the listener that it is different from the others? This cover is one of the two that are not mentioned in All the Songs (Margotin and Guesdon, 2015), probably because it is not counted with the others (CBS issued the album without Dylan's permission).

In The Basement Tapes cover photo, which seems to be a 1975 reconstruction of a 1967 recording session, both Dylan and The Band wear unusual hats (Dylan also wears an unusual sweater) while playing unusual instruments in unusual ways. The interior of the room makes it clear that this is a typical basement, and a tape recorder gives the illusion 
of a studio. Nothing tells us who these people are, but "The Basement Tapes" is written on a cardboard box. As far as I can tell, the whole concept is a kind of staging, an effort to give the material from 1967 a picturesque context for its 1975 release.

The cover of Blood on the Tracks also features some retrospective elements. The head in profile looks like Dylan in 1966, and the sunglasses further suggest the same period. The image is manipulated, but not as much as the image on the Dylan cover. If the Dylan cover tells us that the album is different from the others, the Blood on the Tracks cover tells us the opposite, that this album is typical.

With so much attention on the earlier career of Dylan, it is no surprise that the artist is often portrayed looking or moving to the left, the direction that (according to Kress \& van Leeuwen, 1991) implies an orientation toward the past. The ambiguity and lack of precision of this semiotic language must not be exaggerated. We cannot force the Dylan in the basement to turn around or look to the left, even if the whole The Basement Tapes album is a demonstration of nostalgia.

On the album cover of Desire, Dylan looks more determined and focused on the future, and I associate his clothing, especially the fur over his shoulder and the ribbon on the hat, with a romantic view of artistry as well as a romantic vision of exoticized cultures, such as Native American or Romany. This is also the first album cover that shows the main figure surrounded by green nature - if not a summer picture, then spring or autumn. It contrasts the six or seven earlier covers that correspond with winter: Numbers 1 and 7 (winter clothes), 2 (snow in the street), maybe 4 (winter street?), 5 (indoors by the chimney), 8 and 9 (no leaves on the trees). To paraphrase this change with a cliché, the image suggests a season of new growth for Dylan.

The cover of Street-Legal shows Dylan in a warm place, maybe on a summer's day. Dylan is placed before one of the three fields or elements that constitute the scene: a door, a section of a wall and a staircase. This might be seen as a classic dilemma: if you want to move forward, you have to make a choice, but you do not know what lies behind the door or at the end of the stairs. 
16 Infidels (1983)

17 Empire Burlesque (1985)

18 Down in the Groove (1988)
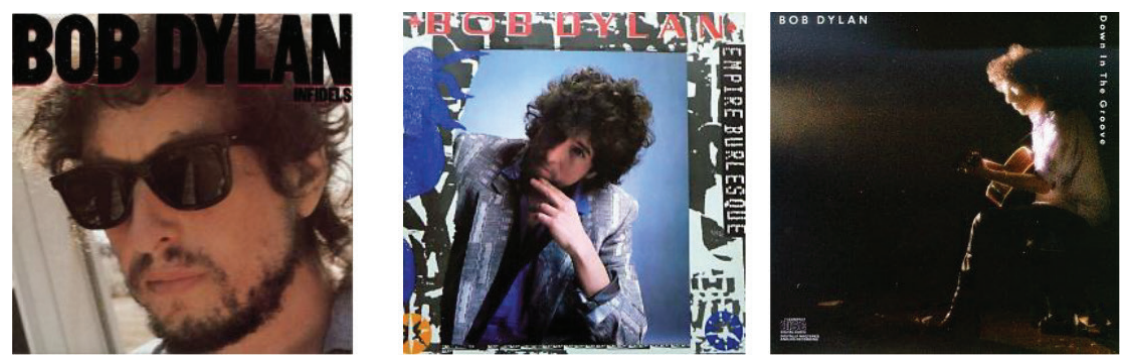

These album covers are not covered by the CC BY licence, and can not be reused.

Of the six studio albums from the 8 os, three covers are photographic portraits. In all three Dylan is more or less oriented towards the left (for the viewer), i.e. conscious of the past, contrary to Desire and Street-Legal. This is especially clear on Down in the Groove, where he sits alone in the spotlight with just one acoustic guitar - as in his first recordings. He occupies one third of the field, the rest (the empty space in front of the musician) is black.

Dylan's main attributes so far have been the guitar and the sunglasses. They are both present on the tree album covers from this decade as well, but not on Empire Burlesque, where he wears a trendy jacket and is placed inside a trendy frame. "Dylans's 23 rd studio album featured a distinct '8os-style' aesthetic that many found tough to take" (Danby). "Regan [the cover-photographer] shows Dylan bowed, wearing an improbable Miami Vice-style jacket which some felt proclaimed the techno-pop tone of the album" (Margotin \& Guesdon, 2015, p. 528). It is surprising to see Dylan dressed so modern, especially when his haircut looks like it did in the 1960s. However, the image gives a good example - or description - of this double belonging, both to the present and to the past.

19 Under the Red Sky (1990)

20 Good as I Been to You (1992)

21 World Gone Wrong (1993)

22 Time Out of Mind (1997) 

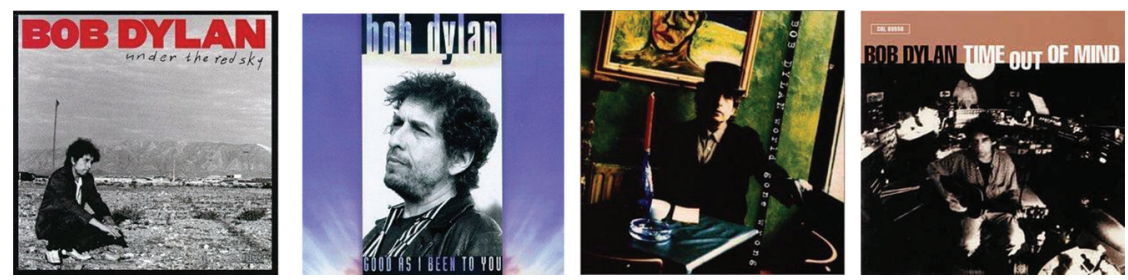

These album covers are not covered by the CC BY licence, and can not be reused.

The four album covers from the 9os differ a lot from each other, not least when it comes to the use of color. They also reveal a balanced attention to the past (left), to the here-and-now, and to the future (right).

If we divide the Under the Red Sky photo into four squares of equal size, we discover two combined models of composition. In the first model what is placed in the two upper squares represents the ideal, while what is placed in the lower squares represents reality. In the second model what is placed in the left-hand squares represents what is known, while what is placed in the right-hand squares is what is still unknown. Dylan is placed in the bottom left-hand square, as a person who still has a lot to learn and experience. He is looking to the right (from the reader's point of view) and seems focused on the future. The "red sky" in the title can allude to some kind of threat or catastrophe. The mountain that divides earth from heaven reminds me of Uluru ("Ayers Rock") in Australia, a red sandstone monolith that is holy for the indigenous Australians - but the photo is actually taken in the Mojave Desert, California (Margotin \& Guesdon, p. 578).

The Good as I Been to You cover shows a man who is serious and has something important to say. He is placed like a vertical axis with blue fields on both sides. In my view this portrait follows up the portrait from The Times They Are A-Changin' (1964), but here he is placed within a frame, which may imply a greater distance to others.

The World Gone Wrong cover shows the artist with a top hat in a café. I do not know how to interpret the hat. It may be a part of some kind of masquerade (cf. The Basement Tapes), which can be serious enough. Or it might refer to the covers from 1965-66, where Dylan is gazing right at the viewer, demanding and self-confident. On the other hand, the album title, written with a Dymo Label Writer, declares that the world has "gone wrong". The whole scene is tilted 10 to 20 degrees to the right, as if to illustrate that fact, but all vertical lines are still parallel. 
The Time Out of Mind album cover shows the artist with a guitar in a studio, maybe referring to his first recordings more than 30 years earlier. The guitar is the same, while the technology in the studio has changed. Dylan stands in the center of a circle made by studio furniture, gazing at the camera/viewer.

\section{3 "Love and Theft" (2001)}

\section{Shadows in the Night (2015)}
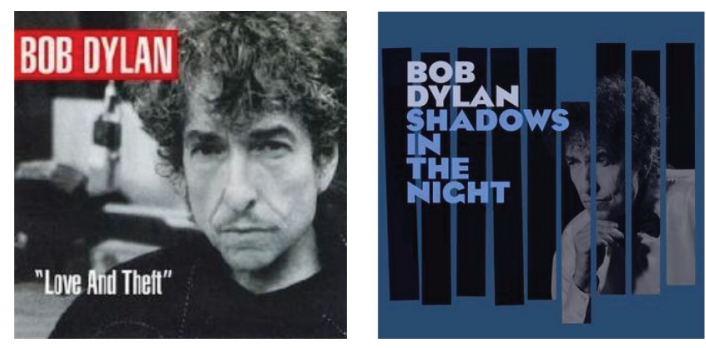

These album covers are not covered by the CC BY licence, and can not be reused.

The final two images to be commented on in this essay were published in 2001 and 2015. They are in black-and-white, and they are both rather dark. The word "theft" and the fictional jailhouse make me think that this is about crime and prison. The cover of "Love and Theft" has much in common with other albums discussed above - for example, the artist's gaze leveled directly at the viewer.

The cover photo of Shadows in the Night has no parallels in my material. Dylan is partly hidden behind bars (not part of the original photo). It resembles the cover of a jazz-album from 1962, namely Freddie Hubbard's Hub-Tones (Blue Note). Here the artist also is behind bars, but, as I see it, the two covers are in many ways rather different from each other. Hubbard is more positive and energic than Dylan. Shadows in the Night is a collection of songs performed by Frank Sinatra (d. 1995), who was at his most active in the 6os. As on the Under the Red Sky cover, the artist occupies a lower quarter of the image. However, on the 1990 album he is placed on the left, maybe concerned about the future, while on the 2012 album, he is placed on the right and seems to look back, maybe at the time that has passed and gone. There are a lot of possible interpretations, but none of them very convincing. It is symptomatic that this cover is the 
only one besides no. 11 (Dylan, 1973) that is not mentioned in All the Songs (Margotin \& Guesdon, 2015).

\section{Summary and conclusion}

To reiterate an important point: I neither can nor wish to say anything about the "real" Dylan. Instead, I look for the one I have already met - the one who exists on records and in pictures and movies. In my material, the mediated singer smiles only twice, namely on albums no. 8 and 9, and (depending on the definition of a smile) maybe on no. 2, 13 and 14, while the more grave Dylan is present on nearly 20 album covers. I expected that as a result of this seriousness there would be more black and white photos, but there I was wrong. All photographs from the 70 and 80 are in color.

On the other hand, the alternation between close-ups and long shots is interesting. Long shots give a feeling of distance, and one result can be seen on the covers of Another Side ... (no. 4) and John Wesley Harding (no. 8), where it is difficult to see the details or the expression in his face. These are two albums that unexpectedly changed the direction in this narrative. A certain distance from the camera allows the context to play a more important role, as we see in Under the Red Sky (no. 19) and Time Out of Mind (no.22, but see also 2, 5, 13, 15?, 18?, 21). For David Machin, distance is an expression of social difference (2010: ch. 2), but in my opinion this may be too narrow a view. I do not see that the distance from the camera corresponds with other variables. Consequently, I give reasons for my conclusions in only ten of the twelve observations listed above - not the first (black and white or color) or the third (distance from camera).

I first try to answer the first research question: I. Can the photographic portraits of Dylan on the album covers be read as a narrative?

Firstly: The findings under the fifth question, "Oriented to the right (future) or to the left (past)?” contribute to an understanding of Dylan's career as a constant and creative conflict between nostalgia (new songs inspired by old songs, new look inspired by old look, etc) and innovation. In five of the 24 photos $(1,3,14,15,19)$ Dylan is more or less oriented towards the right/future, and in about ten of them (he is oriented to the 
left/past $(4$ ? , 8, 10, 11, 12, 13, 16, 17, 20, 24). During the first seven albums he established a sound and a look that he was later expected to repeat, even if the main reason for his long career may just have been his many breaks with these expectations. The record covers seem to comment on and maybe exaggerate this.

The albums from the 70s (nos. 11-15) give a good example, partly because it is so obvious that Dylan is oriented to the left on the covers of Dylan and Blood on the Tracks, and to the right on Desire and Street-Legal. The two principles are visually pulling in opposite directions. Clothing (including hats) and nature show that winter is the dominating season during the whole narrative (see above), and the two summer scenes (no. 14 and 15) correspond with a new peak in Dylan's career, a peak that does not necessarily confirm the established look or sound.

Secondly: On the first four covers the song titles are printed, obviously steering the interpretation. On the other hand, there are three album covers with no verbal signs at all $(7,9,10$, no. 10 with frame), leaving the viewers free to read them in their own, different ways. Related to the titles are the frames, which, among other things, mark the borders between the singer/songwriter and his listeners (see above). I found some kind of frame on ten of the 24 selected album covers (40\%) - either on all four sides, or on one or two sides $(4,5,6,8,11,13,17,19,20,22,24$ ?). Frames are often, but far from always, to be found in portraits where the artist is oriented to the left, e.g. like Blood on the Tracks. Since I do not know how many frames to expect, I compared Dylan's album covers with Van Morrison's and Neil Young's album covers, using exactly the same criteria as for Dylan. The result did not differ much from my premonition: on the 45 Morrison albums with photographic portraits on the front cover, I found 15 with frames (33\%). And on the twelve 12 relevant Young albums, I found two with frames (16\%).

As I see it, the 24 portraits do not tell a different story about Dylan's career than what is told in other modes or modalities. But the visual narrative emphasizes certain elements, namely the creative conflicts between repetition (not understood as stagnation, but as development while following a certain track) and new concepts - and between interaction with his public and keeping to his own ideas in a more stubborn way. 
To answer the other research question ("II. Is there a connection between the cover art on the Dylan albums and religious art?"), I will discuss the three features observed above (under the heading "Some words on religious art”):

Firstly, in a little less than half of the photos, the artist stares directly at the listener or record buyer (no. 2, 4, 5, 6, 7, 8, 9, 17, 21, 22, 23), and in a period at the end of the 60 s this direct gaze was never absent. In religious art, both Eastern and Western, we can divide images of idols or holy persons in one group that illustrate ideas (e.g. Jesus carrying a lamb) or stories (e.g. Jesus is born), and one group where the gods or holy persons - the idols - gazes directly at the viewer, ready to communicate with him or her. (see above). It gives the portrayed a certain authority, and the viewer a sense of contact. Studies of the interior of youth's bedrooms show that a lot is setting up "altars", with candles symmetrically placed around an idol representing values and ideas in modern youth culture (Aagre, 2006).

Secondly, in religious figurative art, a lot of martyrs, bishops, gods, angels, buddhas and others resemble each other so much that they need some attributes to be identified. We have seen that Dylan's main attributes have been the guitar and the sunglasses (see above), but a characteristic hair cut can also make him identifiable. On the cover of Bringing It All Back Home (1965) he holds a kitten, on Basement Tapes (1975) he holds a mandolin, and on World Gone Wrong (1993) I first thought he had a book, but it must be a napkin. Gestures and body language can also help the viewer to identify the idol. One example is Dylan depicted as a thinker (17, 19) in contrast to e.g. a critic/prophet $(3,10$ ?, 20?) or boy-friend (2).

Finally, idol portraits today are often based on the same geometric forms and principles as in earlier times (see the paragraph "Some Words on Religious Art" above), which leads to the same principles for composition. I have looked through my two album cover books (Miles, 2005; Ochs, 2005) without finding any non-harmonic portraits. There are a few examples, like With the Beatles (1963), where the composition at first sight breaks with the harmonic ideals: three heads in a middle row, and one head in the lowest row. This is unusual, but after some time we accept the pattern, probably because it makes the underlying form more visible. 
Some photographs taken from newspapers, etc., e.g. The Roots: Things Fall Apart (1999), have no underlying pattern, but they do not pretend to be portraits in a traditional way.

As a conclusion I will allege that we actually find some elements from early religious art that live on in new contexts, such as modern album cover art. But we have no reason to think that this is something special for Bob Dylan.

\section{Literature}

Aagre, W. (2006). Sporene der hjemme. Om 15-16-åringer og deres hverdagskultur - basert på en undersøkelse om kulturelle og estetiske praksiser i noen utvalgte nordiske ungdomsrom. Doktoravhandling. Trondheim: Norges teknisknaturvitenskapelige universitet.

Bettum, M. A. (2011). Bob Dylans plateomslag i designhistorisk perspektiv. In P. K. Botvar, R. W. Kvalvaag \& R. Aasgaard (Eds.), Bob Dylan. Mannen, myten og musikken. Oslo: Dreyer.

Danby, A. (unknown date). Album covers sometimes just as powerful as his songs. ${ }^{7}$ URL: www.chron.com/entertainment/music/article/Bob-Dylan-s-album-coverssometimes-just-as-1727586.php (downloaded 21.07.2019).

Häger, A. (2009). Bob Dylan and Religion. Scripta Instituti Donneriani Aboensis vol. 21.

Jewitt, C. (Ed.). (2009). The Routledge Handbook of Multimodal Analysis. London: Routledge.

Kress, G., \& van Leeuwen, T. (1996). Reading Images: The Grammar of Visual Design. London \& New York: Routledge.

Maagerø, E., \& Winje, G. (2010). Multimodalitet og læremidler. In D. Skjelbred \& B. Aamotsbakken, (Eds.), Lesing av fagtekster som grunnleggende ferdighet. Oslo: Novus.

Machin, D. (2010). Analysing Popular Music: Image, Sound, Text. Los Angeles: Sage. Margotin, P., \& Guesdon, J.-M. (2015). Bob Dylan All the Songs: The Story Behind Every Track. New York: Black Dog and Leventhal.

Miles, B., Scott, G., \& Morgan, J. (2005). The Greatest Album Covers of All Time. London: Collins \& Brown.

Ochs, M. (2005). 1000 Record Covers. Köln: Taschen.

7 www.chron.com/entertainment/music/article/Bob-Dylan-s-album-covers-sometimes-justas-1727586.php (downloaded 21.07.2019). 
Tobiassen, T. (2012). Kristendommen. In G. Winje (Ed.), Guddommelig skjønnhet. Kunst i religionene (2nd edition). Oslo: Universitetsforlaget.

Winje, G. (Ed.) (2012). Guddommelig skjønnhet. Kunst i religionene (2nd edition). Oslo: Universitetsforlaget.

\section{Author description}

Geir Winje is professor in the science of religion. He works at the University of South-Eastern Norway, mostly with teacher education on different levels. He does research and publishes on three main fields: didactics of religion, art and religion, and modernity and religion. Some central books: Felles, grunnleggende verdier? Menneskerettigheter og religionspluralisme i skolen (Common, basic values? Human Rights and religious pluralism in school, 2017), Guddommelig skjønnhet. Kunst i religionene (Divine Beauty. Art in the Religions, 2nd ed. 2012), Hekser og healere. Religion og spiritualitet $i$ det moderne (Whitches and Healers. Religion and Spirituality in Modernity, 2007).

\section{Forfatteromtale}

Geir Winje er dosent i religionsvitenskap. Han arbeider ved Universitetet i Sørøst-Norge, i hovedsak ved lærerutdanningene. Han forsker og publiserer særlig på tre felt: religionsdidaktikk, religion og kunst, og religion og modernitet. Noen sentrale utgivelser: Grunnleggende felles verdier? Menneskerettigheter og religionspluralisme i skolen (2017), Guddommelig skjønnhet. Kunst i religionene (2. utg. 2012), Hekser og healere. Religion og spiritualitet $i$ det moderne (2007). 



\title{
CHAPTER 6
}

\section{Bob Dylan's Conversions: The "Gospel Years" as Symptom and Transition}

\section{Gisle Selnes}

Professor i allmenn litteraturvitenskap, universitetet i Bergen.
Professor in Comparative Literature, University of Bergen, Norway.

\begin{abstract}
This contribution analyzes Bob Dylan's evangelic conversion in light of other conversions throughout his oeuvre, emphasizing the theological moment of the event of conversion as such. Two important aspects of conversion inaugurate Dylan's born-again output: on the one hand, the isolation and purification of the figure of Christ as the all-pervading "object" of his quest; on the other, the "recoding" of a series of figures and motifs from his earlier work, most of them derived, of course, from the proverbial American songbook. Before and after Dylan's evangelical ruse, the legacy of 18th Century American Transcendentalism as well as Christ as an emblem of the rebel and/or artist constitute two relatively stable religious aspects of his art.
\end{abstract}

Keywords: conversions, Dylan's born-again period, gospel, the Christ Event, Saint Paul, transcendentalism

Sammendrag: Dette bidraget analyserer Bob Dylans evangeliske omvendelse i lys av andre vendinger i forfatterskapet, med hovedvekt på det religiøse momentet ved omvendelsen som sådan. To aspekter ved den evangeliske perioden fremheves: isoleringen av Jesu kroppslige nærvær som absolutt mål for eksistensiell og kunstnerisk søken - og omkodingen av figurer og topoi fra den store amerikanske sangtradisjonen slik at de får en udiskutabel kristologisk valør. På begge sider av Dylans evangeliske raptus undersøkes arven etter den amerikanske transcendentalismen og Kristus som opprørs- og kunstnerskikkelse som to relativt stabile religiøse uttrykksformer. 
Stikkord: omvendelse, Dylans gospelperiode, Kristus-hendelsen, Paulus, transcendentalisme

We're hearing about God all the time, so we better learn how to deal with it. But if we know anything about God, God is arbitrary. So people better be able to deal with that, too

Dylan to Rolling Stone in 2001 (Cott, 2006, p. 419)

1.

When the topic is Dylan and religion, or even Dylan and Christianity, there has been a curious tendency among critics and commentators to downplay the importance of the genuinely evangelical gospel period between 1979 and 1981. In part, this might be an effect of the fluctuations on the cultural "stock market" (to adopt Eliot's phrase), where the value of Dylan's gospel output until quite recently was relatively low, even among his most dedicated fans and exegetes. As is well known, Dylan's sudden embrace of the profoundly conservative, if not downright reactionary, ideology of the West Coast Vineyard Church, where then future president Ronald Reagan found his most attentive audience, came as a shock to those who had lived with Dylan's different avatars of troubadour \& rock rebel personae since the mid 1960s. Indeed, the "Judas" that notoriously resounded in Manchester Trade Hall on May 17, 1966 was echoed at the Warfield in San Francisco 13 years later.

Yet, as always when it comes to Dylan, everything changes, everything passes ... Retrospectively, even the most scandalous of his "anti-career moves" is likely to be hailed as a stroke of genius or accepted as the workings of destiny; even the most disparaged album may suddenly rise to the position of an erstwhile misrecognized masterpiece. In the words of one anonymous Dylan critic, the ice on the surface of almost any "minor" Dylan song may suddenly crack open, revealing astonishing depths where one least expected them. Such miracles happen more or less regularly, for the last couple of decades aided by the Official Bootleg Series (OBS) of rare and unpublished material. Thus, the issuing of Another Self Portrait in 2012 disclosed another, calmer and more lyrical, album underneath the original Self Portrait (1970) - "the only Dylan album that has not been 
underestimated ... enough," in the words of Eyolf $\emptyset_{\text {strem }}{ }^{1}$ - after stripping it of several layers of pointless overdubbing.

In 2017, the OBS wheel had stopped at Dylan's Gospel Years, finally allowing us the awe-inspiring experience of listening through the extant catalog of outtakes and live performances, the latter of which in almost every way rise above the versions found on the studio albums. With the exception of Slow Train Coming (1979) - which, if anything, sounds too slick for its fiery message - the gospel albums (Saved [1980], Shot of Love [1981]) come across as rather unruly, imprecise, almost hasty, as compared with what emerged from the stage.

Even though the reevaluation of Dylan's gospel years had been underway for quite a few years, making the case for a singularly Christian conception of "Bob Dylan's conversion", there is still plenty of reason to treat the concept and the event of "conversion" in the plural. "Dylan is preeminently an American artist," Greil Marcus wrote after the release of Slow Train Coming, "and conversion [...] is a preeminently American way of continuing one's quest" (Marcus, 2010, p. 96). Yes, indeed: Bob Dylan's oeuvre is fraught with conversions, so much so that his embrace of evangelical Christianity in the late 1970s might appear as just another transfiguration in a series of similar events. Dylan's bornagain persona could be seen as a symptom of (or even a clue to) his overarching poetics of conversion, in so far as radical occurrences like this one are still "spontaneously" cast in a religious language as "revelations," "apocalypses," or "miracles" - Saint Paul's experience on the road to Damascus being the proverbial conversion, at least in a Western context.

As Alain Badiou claims in the study Saint Paul and the Foundation of Universalism, Paul is "the poet-thinker of the event," that is, the person who "brings forth the entirely human connection [...] between the general idea of a rupture, an overturning, and that of a thought-practice that is this rupture's subjective materiality" (Badiou, 1998, p. 2). Even from a non-religious perspective, probably the most quintessential event in

1 Østrem, Eyolf. Self Portrait (1970) - introductory remarks, from dylanchords.info; http://dylanchords.info/10_selfportrait/index.htm (downloaded 28.06.19). 
world history is that envisioned by the founder of Christianity - even more so than that of the "Anti-Christian" prophet, Nietzsche, whom Dylan as well as Badiou more or less respectfully denigrate. Not only did Paul go through the paradigmatic conversion from the powerful Jew Saul (the great) to the apostle Paul (the small); he also thought through the conditions of possibility for this event and how to implement it in the existing order of the Roman Empire: for such a revolution to become possible, a new subjective position (that of the apostle) as well as a new discourse (that of faith, or declaration) had to be invented. This is also what preoccupies Dylan's born-again persona, although his reflection on the process is of a less systematic, and of course more artistic, kind.

\section{2.}

Religion permeates Dylan's oeuvre, on several levels, and many attempts have been made to map "the gospel according to Dylan" - or Dylan's uses of the Scripture - as well as Dylan's more "ecumenical" religiosity throughout his career as a songwriter. As every reader of these lines probably knows, Dylan's early repertoire included several gospel blues songs. After a couple of conversions, in 1967 he released "the first Biblical rock album," John Wesley Harding, and every since a certain "American" mysticism runs along the shifts and turns of Dylan's musical and poetic work. What makes the gospel years albums stand out with respect to the bulk of Dylan's proto-religious work is their stark reliance on a personal, soteriological Christology - that is, on the radical effects of what Badiou refers to (after Saint Paul) as "the Christ-event": the incarnated God, Jesus Christ, was sacrificed in order to save mankind from sin; and by defeating death, He has also relieved man from the fatality of his earthly existence. This event changed everything - love, hope and faith are the new gospel, replacing the cosmic mythology of pagan religion as well as the law-regulated discourse of Jewish civilization.

There are two important sides to the conversion that inaugurates Dylan's born-again output: on the one hand, the isolation and purification sublimation - of the figure of Christ as the all-pervading "object" of his artistic and existential quest; on the other, the re-charging or re-coding of 
a series of figures and motifs from his earlier work, most of them derived from the proverbial American songbook.

The first of these aspects is important in so far as there are several avatars of Jesus haunting Dylan's songs at different points in his career. There is, for instance, Jesus the proto-Socialist rebel of Dylan's Guthriesque period, most forcefully expressed in Woody Guthrie's own "Jesus Christ (They Laid Jesus Christ in His Grave)," echoes of which are heard in early Dylan songs such as "Long Ago, Far Away" (1962). The other main avatar is Christ as the suffering artist, reminiscent of Gérard de Nerval's postromantic "Christ aux Oliviers" raising his meager arms towards the sky "comme font les poètes" (like the poets do). In Dylan's work, this is the Christ who dominates his mid-1970 output - most notably Blood on the Tracks (1975), where "Shelter from the Storm" and "Idiot Wind" are telling examples, but this avatar also looms large on his next albums, Desire (1976) and Street-Legal (1978), the immediate precursor of his evangelical trilogy.

Dylan's eventful encounter with a living Christ could thus be cast as yet another incarnation of an already familiar figure. In a Tuscon hotel room, in late 1978, "Jesus put his hand on me," Dylan recalls; "It was a physical thing. I felt it. I felt it all over me. I felt my whole body tremble. The glory of the Lord knocked me down and picked me up" (Hughes, p. 276). However, this time Jesus goes from being a poetic symbol or cultural "role model" to a living presence: His most prominent characteristic, according to the Pauline doctrine. Whereas, earlier, Christ had been one figure among a host of other inhabitants of "the invisible republic", from now on He stands forth as the gravitating and organizing center of Dylan's artistic universe. Roughly three quarters of the songs written between 1979 and 1981 are concerned with, or name, Jesus Christ.

Moreover, the Americana props and dramatis personae of Dylan's earlier songs are transfigured by his personal Christ-event. Take, for instance, the train motif, so characteristic of blues and folk music, and a hallmark in Dylan's repertoire from the early 196os and right up to Street-Legal's "Where Are You Tonight? (Journey Through Dark Heat)" and "Señor (Tales of Yankee Power)." From the latter song's apocalyptic/ eschatological intimations only a small step is needed for a full-fledged Christian/Evangelical scenario to emerge. In the words of Alan Lomax: 
Ever since the first locomotive whistle split the quiet air of the South and the black engine thundered down the rails, snorting steam and fire like the horses of the Apocalypse, the righteous have been "buying tickets on the snow-white heavenly express for glory." For the gambler, the back-biter, the crap-shooter, and other back sliding sinners, the Black Diamond Express, manned by Satan, was booked and bound for the lower regions. (Lomax, 1960, p. 467)

Examples are too abundant to warrant enumeration. Suffice it to say that Lomax Jr.'s paraphrase is clearly indebted to “This Train" (or "Dis Train”), a traditional gospel blues turned into a hit by Sister Rosetta Tharpe, among others, and performed - somewhat half-heartedly - by Bob Dylan on the so-called Minneapolis Party Tape (1961); the song also appears in what allegedly was Dylan's "Bible” in the earliest phase of his artistic career, namely Woody Guthrie's Bound for Glory (1943).

Tellingly enough, the first album in Dylan's "holy" trilogy, Slow Train Coming (1979), indulges in railway symbolism, starting with the quasi-allegorical drawing on the album cover, and culminating with the title song, "Slow Train." Whereas Lomax Jr.'s matrix, “This Train," is an upbeat, joyous celebration of imminent redemption, Dylan's "Slow Train" is - as the title indicates - a much slower, and gloomier, song. At least in part, this effect may be traced back through its echoes from Sam Cooke's "A Change Is Gonna Come" (1963), to Dylan's own "Blowin' in the Wind" (1962), to which Cooke's song was presumably written as a response. Both of these songs envision a measured process of alteration of the present situation, worn down by injustice and (racial) oppression, thus making the case for an appropriate genealogy - even more so since Cooke's lyrical anthem takes its cue from the other great symbol of destiny and existence, namely the river.

Still, "Slow Train" lingers on the threshold between the old and the newborn Dylan. Describing the looming change just ahead, it avoids to name the Christ event, concentrating instead on the socio-political diagnosis professed by the Vineyard Church and its benefactors, such as the ultra-reactionary theologian-cum-broadcaster Hal Lindsey, from whom there are several echoes on the album. Does this explain, one might ask, Dylan's need to extrapolate this particular song, "Christening" it by 
fitting it into the interpretational context of the album, drawing on the laden symbolism of the "Gospel train"?

\section{3.}

Framed by the trilogy of gospel albums released between 1979 and 1981 - and now supplemented by the amazing Trouble No More 10 CD box Dylan's born-again output stands out as an eruption of creative energy. In addition to the more than fair amount of voices complaining that Dylan had sold out to the smug gang of Californian right-wing evangelists, there are also those who celebrate that Dylan, despite ideological shortsightedness, once again "got his mojo back". Paul Williams, who made the Fox Warfield Theater Concerts in San Francisco early November 1979 a starting point for his three-volume study Bob Dylan: Performing Artist (1992-2004), is a case in point: “Dylan's energy has been reborn too, and that's the good news as far as I'm concerned" (Williams, 1980, p. 22). In this sense, Dylan's conversion to evangelical Christianity fits perfectly the overall pattern of his idiosyncratic development as an artist: having exhausted creatively a particular genre or tradition, he moves on, seeking out other chapters of "The American Songbook" to draw inspiration from and make his amends in. As a rule (though not without exceptions), three albums are the average output "per conversion”. One might claim that Dylan's latest turn to vintage, jazzy Tin Pan Alley pop amounts to an insistent manifestation of this pattern, the third album of the trilogy being a triple album: Triplicate (2017) - whereas the born-again trilogy would be the purest "post-evental" outburst of refueled creativity, perhaps only comparable to the revolutionary electric trilogy from the mid1960s, when Dylan reinvented himself as a hip modernist rock poet.

What makes the evangelical albums into a special case is the downward spiral of Dylan's career after Desire (1976) - a decline that, in my view, includes Street-Legal, a relative artistic failure. This is still a bone of contention among Dylan scholars and fans, though, Street-Legal probably being the most controversial of his entire oeuvre when it comes to the question of quality: it has been hailed as a masterpiece and condemned as a pretentious flop by different, and equally renowned, scholars. "Most of 
the stuff here is dead air, or close to it," Greil Marcus wrote in 1978 (Marcus, 2010, p. 88), a verdict with which I personally sympathize. With a few honest exceptions, most notably "Señor (Tales of Yankee Power)," the material is rather nondescript; Dylan's voice sounds little less than wornout, and the lyrics are either too banal or too contrived for his own good. Yet, for that very reason, the spiritual and musical regeneration after his evangelical conversion stands out as a Pauline event of sorts, an artistic miracle even in the eyes of a non-believer: an artist capable of making great music, and perfectly adjusted, even though profoundly disturbing, lyrics, within such narrow ideological frames, is truly worthy of both Grammys and Nobel prizes ... At the other end of the gospel sequence, Dylan's creative genius starts to dwindle, and despite occasional masterpieces such as "Blind Willie McTell" and "Brownsville Girl," he will not get back on track until the 1990s - after yet another prolonged return to acoustic folk and blues standards.

Thus one might risk the hypothesis - as has been done for example by Norwegian critic Kaja Schjerven Mollerin (Mollerin, 2007, p. 132) - that Dylan's evangelical conversion was most forcefully motivated by artistic rather than by genuinely religious concerns. With Slow Train Coming Dylan enters a musical (and lyrical) terrain he had never really visited before, namely the electric gospel/soul tradition that did not form part of the middle-class bohemian and/or political folk and blues revival, and that was equally foreign to the hip rock 'n' roll scene. This does not amount to claiming that his conversion was "calculated" or "fake" in any way, only that for a consummate artistic nature like Dylan's any truly existential "inner experience” would probably be mediated, or at least accompanied, by a musical conviction. It is unthinkable that Dylan would be able to capture the essence of that place and moment had he not been a genuinely converted and convinced member of the congregation. Just like he picked up the radical - and perhaps revolutionary - spirit of the times when he wrote songs like "Blowin' in the Wind," "A Hard Rain's A-Gonna Fall" and "The Times They Are A-Changin", around 1980 he seized and transformed a conservative, if not downright reactionary, version of Christianity that was only just beginning to emerge as a significant ideological force. In the words of Dylan himself, "That spirit was in the air, and I picked it up" (Cott, 2006, p. 276). 
Attempts have been made to elevate Dylan into an autodidactic theological genius of sorts. Thus, Stephen H. Webb, in his highly recommendable Dylan Redeemed (2006), praises Dylan's art as a kind of "theo-acoustics" and hails Dylan himself as "one of the greatest American theologians of the latter half of the twentieth and the beginning of the twenty-first century" (Webb, 2006, p. 16). Webb's analysis of the proto-religious nature of Dylan's sound is illuminating, as is his inside view of the evangelical movement and his take on Dylan's gospel songs as the origin of "Christian rock" as a genre in its own right. Yet when it comes to the evaluation of Dylan's theological originality, Webb seems to lose control over his own enthusiasm for the Gospel according to Dylan. Asked by Charles M. Young - in the 1985 MTV interview - whether he agrees that there is an element of self-righteousness on the born-again albums, Dylan answers affirmatively:

Yes, that's a fair perception. [...] Self-righteousness would be to repeat what you know has been written down scripturally someplace else. It's not like you're trying to convince everybody of anything. You're just saying what the original rule is. It's just coming through you. But if someone can get past you saying it, and just hear what the message is - knowing that it's not coming from you but through you - I don't see anything wrong in that. (https://invidiou.sh/watch?v=xliBjqn1lJQ)

Such, I believe, is the (perhaps deceptively simple) truth about Dylan's theology: it does not stem from Dylan, but from the Scriptures ... as taught by the charismatic evangelical preachers of the early 1980s. In no way does he try to be "original" or "inventive". His approach is dogmatic, self-righteous, in accordance with the teaching of the Vineyard Church that ignited his spiritual enthusiasm. Still, the enthusiasm is unmistakably real, and originality is no doubt a spurious criterion when it comes to the lyrical content of gospel music.

Thus Greil Marcus is perfectly entitled to speak, in the abovementioned review of Slow Train Coming, of the evangelical Dylan's "Amazing Chutzpah" - i.e., not the "amazing grace" of redemption but the contempt and condemnation of a self-righteous preacher - and to claim that " $t]$ his is not the music of a man who's thinking something through, but of a man who's plugging in" (Marcus, 2010, p. 93). However, 
Marcus' implicit negative judgment is unwarranted, and he blatantly errs when trying to isolate Dylan's spiritual chutzpah as an anomaly within the context of (traditional) American religious music, contrasting it with a more patient, empathic and meditating version of Christianity - as if the latter were the "authentic" vein from which the former deviates. In the liner notes to his superb anthology of pre-war gospel, John Fahey highlights the more than palpable tendency "to communicate "cheap Grace" [...] through emotional, exciting, provocative and stimulating entertainment, especially through the twin talismans of noise and rhythm" (Fahey, 1997, p. 13). This is the immediate context of Dylan's gospel music: rhythm, voice and other musical effects are used so as to attune the artist and his audience to a long-since established set of religious rules and truths, interspersed with brutal memento mori and (often complacent) eruptions of evangelical joy: "Sinner, You'll Need King Jesus”; "You Better Quit Drinking Shine”; "Are You Bound for Heaven or Hell?”; "Death's Black Train is Coming"; "I'm on My Way to the Kingdom"; "Lord, I'm the True Vine" - and so on and so forth. In such a frame, Dylan's chutzpah comes across as far less amazing than Greil Marcus would have it.

To return to Stephen H. Webb's judgement: despite his hyperbolic attempt to turn Dylan into a master theologian, Webb inevitably realizes that musical rage and lyrical self-righteousness - rather than theological subtleties - are the stuff that Dylan's evangelical songs are made of. Halfway through Dylan Redeemed, he quite appropriately observes that "[o]ne of the reasons Slow Train Coming was so musically effective is that it brought the apocalyptic rage that fueled much of his best early work to a fulsome culmination" (Webb, 2006, p. 65). With that position I totally agree.

\section{4.}

Incarnation and apocalypse loom large in Dylan's evangelical universe. In a sense, they are two sides of the same coin: the apocalypse effectively starts with the divine act of kenosis, i.e. the emptying out of God's transcendental potency into His own creation through the birth of Jesus. This "conflation" of transcendence and worldliness makes all the difference in the world - quite literally the only truly significant difference there 
is: "Now there's spiritual warfare and flesh and blood breaking down / Ya either got faith or ya got unbelief and there ain't no neutral ground," as Dylan has it in "Precious Angel." Incarnation introduces a "universal exception" to the way of all flesh - a principle of hope, faith and love while doing away with old cultural categories: "There is neither Jew nor Greek, there is neither bond nor free, there is neither male nor female: for ye are all one in Christ Jesus" (Gal. 3:28). To this rather straightforward Pauline theology, Dylan adds the defiant words of Christ from Matthew 10:34 ("I came not to send peace, but a sword"), sundry scenarios from The Book of Revelation and the Old Testament prophets, most notably Jeremiah, whose prediction appears on the album sleeve of Shot of Love: "Behold, the days come, saith the Lord, that I will make a new covenant with the house of Israel, and with the house of Judah" (31:31) - a text often used by Jewish Christians, of whom Dylan certainly is one, "to emphasize continuity with their ancestral faith" (Webb, 2006, p. 163).

Such is the basic set-up that calls for immediate conversion: "You Changed My Life"; "Gonna Change My Way of Thinking"; "When You Gonna wake Up?"; "Gotta Serve Somebody" ("it may be the devil or it may be the Lord"); “Are You Ready?"; "Ye Shall Be Changed” - to quote only a few titles and phrases that underscore Dylan's polarizing interpretation of the new covenant. Even if the Gospel primarily concerns spiritual reinvigoration, Dylan has a particular affinity for the physical side of the incarnation/apocalyptic scenarios, be it in the form of the "eroticization" of redemptive love or of violent anticipations of the last judgment - if not in a curious mix of the two, as in the chorus from "Saved": "I've been saved / By the blood of the lamb."

Several of Dylan's gospel songs spell out the elementary difference between the old and the new covenant, highlighting the (again: Pauline) opposition between the letter of the law - written in the flesh - and the saving grace of spiritual life. "Pressing on" is an unambiguous case in point:

Many try to stop me, shake me up in my mind

Say, "Prove to me that He is Lord, show me a sign"

What kind of sign they need when it all come from within

When what's lost has been found, what's to come has already been? 
Perhaps one should hear these questions as being addressed to the phantoms of Dylan's Jewish past - i.e. the Messianic, "sign-seeking” version of the proto-Christian religion - to which the singer opposes the Pauline dogma that revelation has already occurred, only that the new covenant is of a spiritual rather than of a law-regulated kind. Somewhat more subtly, in "Precious Angel," the female "you" is seen as "suffering under the law," after which the singer conjures up a scenario where they are both sharing the same dismal past: "We are covered in blood, girl, you know our forefathers were slaves / Let us hope they've found mercy in their bone-filled graves." It does not take an undue amount of hermeneutic acuity to figure out the conjunction of literal and spiritual slavery, she ("you") being the descendant of black slaves, while he ("I") is a converted Jew. Whereas their forefathers' physical remains are evoked in all their material horridness, the beloved Precious Angel lightens up the night and shows him the way out of Egypt "to the judgment hall of Christ."

In a far more brutal vein, an earlier verse of "Precious Angel" imagines the destiny of those who do not partake in the bliss of the chosen few:

My so-called friends have fallen under a spell.

They look me squarely in the eye and they say, "Well, all is well."

Can they imagine the darkness that will fall from on high

When men will beg God to kill them and they won't be able to die?

Such "phantasmatic" scenarios of divine violence abound in Dylan's Gospel albums: "Are you ready for the judgment? / Are you ready for that terrible swift sword? / Are you ready for Armageddon? / Are you ready for the day of the Lord?" ("Are You Ready?"); “The iron hand it ain't no match for the iron rod / The strongest wall will crumble and fall to a mighty God" ("When He Returns"); etc. Taken together, they testify to the limits of Dylan's Paulism: here we are clearly dealing with a version of the dogma of "premillennialism" - which was foreign to Saint Paul, commonly traced back to Saint John's more fanciful Revelation (20:1-6) - according to which Christ will return before the end of historical time to inaugurate the Millennium of Paradise on earth. This is also the teaching of modern evangelical churches. "In his first coming, Messiah defeated the enemies of God", writes Ken Wilson, one of the gurus of Dylan's own Vineyard Church: 
In his second coming, Messiah will destroy the enemies of God. In Jesus' first coming, Satan, sin, and death were judged and condemned at the cross [...]. In Jesus' second coming, Satan, sin, and death will be removed from the new heavens and the new earth and be thrown into the lake of fire. (Wilson, 2009, p. 50)

Dylan is far from the only acolyte to give these eschatological visions another turn of the screw, fantasizing about the twinges and torments of desperate sinners on the Day of Wrath.

Nevertheless, in their own roundabout way, these admittedly perverse scenarios illustrate the theological insight into the complexities of God's nature. Despite the new gospel's insistence that Love has rendered the Law obsolete, there is a remnant of violent arbitrariness that cannot be expelled without throwing grace into the bargain. "[L]ove which suspends the Law is necessarily accompanied by the arbitrary cruelty which also suspends the Law," writes Slavoj Žižek in one of his theological musings: "This is also why it is wrong to oppose the Christian God of Love to the Jewish God of cruel justice: excessive cruelty is the necessary obverse of Christian Love" (Žižek, 2006, p. 187).

It is as if Dylan needs these pangs of real - physical - pain and bliss to remind or convince himself of the reality of Christ's incarnation and sacrifice ("the blood of the lamb") and of His presence on the scene of conversion as well as on that of the Final Judgment. In want of readable "signs" of grace, as it were, Dylan conjures up all kinds of scenarios involving palpable evidence that salvation and condemnation are real. This also goes for the here-and-now of the converted singer: in several of his gospel songs, Dylan stages a martyr-like apostolic persona, scorned and virtually ostracized from (secular) social contexts because of his Christian belief: "They show me to the door / They say don't come back no more" ("I Believe in You"); "Stop your conversation when he passes on the street / Hope he falls upon himself, oh, won't that be sweet" ("Property of Jesus"); etc. The presence of Jesus becomes manifest through the schisms that open between the true Christian and the non-believer.

Up to a point, the same holds for the converted/apostolic persona's relation to his own (spiritual) kin. There is hardly any sense of ecclesiastic collectivity in Dylan's gospel songs; for the most part, they address the non-Christian "other" or God/Christ - if not an eroticized female figure, 
which in some way represents divine grace. Even in the latter case, Dylan seems to presuppose an "agonism" of sorts, in that the singer requires a "sign" or "sacrifice" from the other before compromising himself to him or her. This is clearly seen in the remarkable chorus of "Do Right to Me Baby (Do unto Others)": "But if you do right to me, baby / I'll do right to you, too / Ya got to do unto others / Like you'd have them, like you'd have them, do unto you." Again, Dylan's rather willful theology is working hermeneutic miracles. Quite obviously, "Do Right to Me Baby" is Dylan's take on the so-called Golden Rule: "Therefore all things whatsoever ye would that men should do to you: do ye even so to them: for this is the law and the prophets" (Matt. 7:12). Yet by adding a conditional "if" ("if you do right to me, baby /

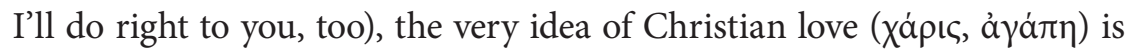
thwarted, its point being precisely that one should love unconditionally, even one's enemies, without expecting anything in return. You have been told that you shall love your neighbor and hate your enemy, Jesus says in His Sermon on the Mount: "But I say unto you, Love your enemies, bless them that curse you, do good to them that hate you, and pray for them which despitefully use you, and persecute you" (Matt. 5:43-44). This, of course, is a far cry from the bargain implied by Dylan's evangelic persona. (It might be a fair guess that Dylan's "creative" misreading echoes the non-religious stock blues line "How can I do right to you baby when you won't do right yourself?" - as sung for example by Kokomo Arnold in "Milk Cow Blues" and by Josh White's in his version of "Good Morning Blues.")

To this we may add Dylan's idiosyncratic communication with his audience, from the stage as well as in interviews. A certain "passion of the real" - a desire to touch, however obliquely or unconsciously, the explosive core of ideological antagonism - is clearly involved in the interaction between the artist and the crowd. Even though Dylan, towards the end of the Gospel Tour, makes some amusing attempts to engage the audience in singalongs and handclapping - as if he were the minister of a gleeful congregation - for the most part he seeks confrontation, like an evangelist acting out his possession by the Lord. In the words of Sean Wilentz, "Dylan reinvented the southern tent-show revival, starring himself as the singer and hellfire preacher" (Wilentz, 2010, p. 182). Yet if anybody should still warrant the claim that Dylan ought to be counted as one of the great 
American theologians, let him or her lend an attentive ear to his so-called "gospel raps"; they are the words of a rambling, yet inspired, layman, not those of a theologian. The main purpose of these raps or rants is precisely to stage the "enthusiastic" disciple - touched by Christ or filled with the Holy Spirit - entirely and dogmatically faithful to the Christ event.

\section{5.}

"Slow Train," the eponymous song from Dylan's first evangelical album, marks the threshold between the secular and the confessional part of his oeuvre. At the other end of the gospel sequence, Shot of Love (1981) appears as a transitional album, including several songs that hover in a "reconversional" zone between the engaged evangelism and a more detached transcendental symbolism. Arguably, there are only two properly evangelical tracks on the latter album: "Property of Jesus" and "Dead Man, Dead Man". The remaining songs - with the exception of the wholly nonreligious "Lenny Bruce", probably the weakest track on the album - tarry with Christian ideas and concepts, yet without relating them to the Gospel of Jesus. This goes for the title song, which never clarifies what kind of love is wielded as a panacea against all kinds of evil, as well as for "The Groom Still Waiting at the Altar", in which the Biblical images of bride and groom remain equally ambiguous. The same goes for the pious eroticism of "Heart of Mine" and the decadent, dystopic scenarios of "Trouble".

To my mind, however, "In the Summertime" and "Every Grain of Sand" stand out as the album's most emblematically transitional songs. Each in its own way, they seem to wave goodbye to the life-changing intimacy with a "personal Jesus", opening up a more complex and less self-righteous, yet still somehow transcendental, artistic and existential horizon.

An emphatically retrospective atmosphere characterizes "In the Summertime". Yet the true nature of the narrated event, as well as its addressee, remain undisclosed:

I was in your presence for an hour or so

Or was it a day? I truly don't know.

Where the sun never set, where the trees hung low

By that soft and shining sea. 
Several of Dylan's gospel songs mix eroticism and religious experience in a way reminiscent of the poetic tradition stretching from the Song of Songs through baroque "mystical" poetry and up to modern (postromantic) poets like Hopkins, Auden and others. Here, however, it's not even clear whether there is a religious moment involved at all. Only two things remain certain: a momentous meeting has taken place, and the "affair" is irrevocably over. Summer is gone; autumn has come; winter is at the door - yet the event has marked the singer, lastingly:

I'm still carrying the gift you gave,

It's a part of me now, it's been cherished and saved,

It'll be with me unto the grave

And then unto eternity.

Even though physical and emotional intimacy is a thing of the past, love remains an invaluable gift; it has affected the singer in a profound way, restoring his belief in the future.

Broadly speaking, with Shot of Love Dylan seems to return to a less fiery religious outlook, at best to an "interiorization" or "privatization" of the apocalyptic gist. I say that Dylan "returns" to such an outlook, since this is a stance that also qualifies his first artistic conversions: Dylan's visionary poetics is heard most distinctly, perhaps, in songs like "A Hard Rain's A-Gonna Fall” (1962), "Lay Down Your Weary Tune” (1963), "Mr. Tambourine Man” (1964), and "Visions of Johanna" (1966). It is a kind of poetic religiosity, lingering somewhere between traditional American Transcendentalism and Poe's "Dark Romanticism", akin to what Harold Bloom (and others) have referred to as "The American Sublime" (e.g. Bloom, 2016). "A leaf, a drop, a crystal, a moment of time, is related to the whole, and partakes of the perfection of the whole", writes Emerson, the American Transcendentalist par excellence, in his powerful essay Nature (1836): "Each particle is a microcosm, and faithfully renders the likeness of the world" (Emerson, 1971, p. 27). "I can see God in a daisy," echoes Dylan in a 1975 interview: "I can see God at night in the wind and rain. I see creation just about everywhere. The highest form of song is prayer" (Ellison, 2004, p. 104).

"Every Grain of Sand" is probably the Dylan song that most effectively gives voice to this vision. ("Ring Them Bells" might be another 
candidate.) The rejoicing of the born-again proselytizer has blown over; the singer is weighed down by grief and remorse, feeling trapped by an inexorable causal chain harking all the way back to Cain's fratricide. Yet, rather than paralyzing, these are circumstances that enable him to put himself and his environs in a broader perspective - sub specie aeternita$t i s$, as it were - as is eloquently expressed in the changing refrain: "In the fury of the moment I can see the Master's hand / In every leaf that trembles, in every grain of sand." Throughout the song's six verses, the singer appears as a repentant sinner, a dreamer, and a quasi-allegorical everyman on his journey through life. Yet after each bitter retro- or introspection, he manages to lift his eyes and recognize a divine purpose behind the shifting winds of fortune - "every hair is numbered like every grain of sand.” As Stephen Webb writes, in Dylan's poetic vision, “[t]he sacred is found in everyday details rather than in the highs of peak experiences, because God has designed it all" (Webb, 2006, p. 165).

Webb, who knows way more about these things than the average Dylan critic, also suggests that "Every Grain of Sand" reads as Dylan's leavetaking with charismatic revivalism - i.e., belief in the necessity of being born again to a life in communion with Christ - and the budding embrace of a quasi-Calvinistic providentialism - belief in the pre-arrangement of all that is by a deus absconditus (Lucien Goldman's “dieu caché”). There is a hidden purpose behind everything; serenely, the "Master's hand" unfolds a meaningful pattern. Yet this is a laborious, meticulous process which it takes time to experience; it cannot be deciphered in an ecstatic encounter with the Son of Man. In a sense, Dylan has returned to a more genuinely visionary experience of "the great chain of being," a kind of "immanent" transcendentalism that is not foreign to the idea of God: deus sive natura, as in the Spinozian formula.

To my mind however, rather than an ultra-Protestant stance, as Webb would have it, Dylan adopts a "pagan" theism reminiscent of the Orphic poetics that informs his early visionary songs. Traces of this mythology are clearly present in Old Testament texts, most notably in the Books of Wisdom, like Ecclesiastes, from which Dylan borrows (or steals) a phrase or two. The song's last verse unfolds a scenario in which an ocean-like cosmic harmony is punctured by a certain "modernist" irony: 
I hear the ancient footsteps like the motion of the sea

Sometimes I turn, there's someone there, other times it's only me

I am hanging in the balance of the reality of man

Like every sparrow falling, like every grain of sand

Despite echoes from Matthew - from whom the sparrow, as well as the hair in verse six, probably originate - "Every Grain of Sand" is definitely not an evangelical song. Dylan has stepped out of the magic circle of charismatic Christology, reaching out for new inspirational zones. "[Y] ou'd swear it was a hymn passed down through the ages," writes Tim Riley (1992, p. 270). It reads like a psalm, a prayer, addressed not to a personal Jesus, but to the creative spirit that supports all that there is.

Thus, "Every Grain of Sand" reminds us of the fact that Dylan frequently places a seminal song as the last one on his albums. Again, he is on the move, looking for unexplored musical territories - always converting, always converted, as in the title of Rob Wilson's study, which also includes a chapter on "the Born-Again Refigurations of Bob Dylan" (Wilson, 2009, p. $166 \mathrm{ff}$ ). The intransience, or inevitability, of conversion is one of the stockpile topics of Dylan's musical ethos - "the rising tide that lifts all ships" - that is, the great American song tradition.

It is hard to tell if this should be regarded as a step forward or backwards. A conversion is, etymologically speaking, a turn (from Latin "con-vertere," to turn around or transform); Bob Dylan's conversions are turning points in his dealings with a tradition that appears, Eliot-like, as a "simultaneous order," a kind of historical timelessness. In this particular case, the turn is even more emphatically "pluridirectional". Ecclesiastes - parts of which were set to music by Pete Seeger, and appropriately titled "Turn, Turn, Turn" - famously speaks about the eternal recurrence of God's creation: "The thing that hath been, it is that which shall be; and that which is done is that which shall be done: and there is no new thing under the sun" (1:9). Dylan has gone through a spiritual conversion in full view of the audience: he has met Jesus; he has been saved, changed, born again. Now he (re)turns to a more "primordial" kind of religiosity - a mix of Orphism and Stoic Christianity, with echoes from Old Testament wisdom and a hint of Calvinism - while moving towards new artistic hunting grounds. "I made my statement", Dylan told Robert Hilburn in 
November 1980, "and I don't think I can make it any better than in some of those songs. Once I've said what I need to say in a song, that's it. I don't want to repeat myself" (Cott, 2006, p. 284). Thus speaks the relentless poetics of conversion at work in Dylan's art, making it imperative to turn even from the "Saving Grace" of Christ.

\section{Literature}

Badiou, A. (2003). Saint Paul: The Foundation of Universalism. Stanford: Stanford University Press.

Bloom, H. (2015). The Daemon Knows: Literary Greatness and the American Sublime. Oxford: Oxford University Press.

Cott, J. (Ed.). (2006). Dylan on Dylan. London: Hodder \& Stoughton.

Ellison, J. (Ed.). (2004). Younger than That Now: The Collected Interviews of Bob Dylan. New York: Thunder's Mouth Press.

Emerson, R. W. (1971). Nature [1836]. In The Collected Works of Ralph Waldo Emerson, vol. I. Cambridge, MA: The Belknap Press of Harvard University Press.

Fahey, J. (1997). American Primitive vol. I: Raw Pre-War Gospel (1926-36). (Liner notes). Austin: John Fahey's Reverent.

Hilburn, R. (2009). Corn Flakes with John Lennon and Other Tales from a Rock " $n$ " Roll Life. New York: Rodale.

Hughes, K. (2006). Interview with Karen Hughes, The Dominion (Wellington, New Zealand). In J. Cott (Ed.), Dylan on Dylan. London: Hodder \& Stoughton.

Lomax, A. (1960). The Folk Songs of North America in the English Language. London: Cassell \& Company.

Marcus, G. (2010). Bob Dylan: Writings 1968-2010. London: Faber \& Faber.

Mollerin, K. S. (2007). På St. James hotell. Agora. Journal for metafysisk spekulasjon 1-2, 126-150.

Nathan, R., \& Wilson, K. (2009). Empowered Evangelicals: Bringing Together the Best of the Charismatic and Evangelical Worlds. Idaho: Ampelon Publishing.

Riley, T. (1992). Hard Rain: A Dylan Commentary. New York: Vintage Books.

Webb, S. H. (2006). Dylan Redeemed. From Highway 61 to Saved. New York: Continuum.

Wilentz, S. (2010). Bob Dylan in America. London: The Bodley Head.

Williams, P. (1980). Dylan: What Happened? Encinitas: Entwhistle Books.

Wilson, R. (2009). Be Always Converting, Be Always Converted. An American Poetics. Cambridge MA: Harvard University Press.

Žižek, S. (2006). Neighbors and Other Monsters. In K. Richards, E. L. Santner \& S. Žižek, The Neighbor: Three Inquiries in Political Theology. Chicago: University of Chicago Press. 


\section{Author description}

Gisle Selnes is professor in Comparative literature at the University of Bergen, Norway, where he also directs the Research group for Radical Philosophy and literature (RFL). Selnes has written numerous articles on literary, philosophical, cultural and historical issues, ranging from colonial Latin American writings to Lacanian psychoanalysis. His books include Det fjerde kontinentet. Essays om America og andre fremmede fenomener (The Fourth Continent. Essays on America and Others Strange Phenomena, 2010), on the topic of discovery, critical theory and the origins of the essay as a genre; an annotated translation of César Vallejo's Trilce; and the voluminous Den store sangen. Kapitler av en bok om Bob Dylan (The Everlasting Song. Chapters from a Book on Bob Dylan, 2016). In addition, Selnes has published a number of popular essays on Dylan in the press and lectured widely on Dylan's poetics of song lyrics to an academic as well as to a more general audience.

\section{Forfatteromtale}

Gisle Selnes er professor i allmenn litteraturvitenskap ved Universitetet i Bergen, der han også leder en forskergruppe for Radikal filosofi og litteratur (RFL). Selnes har skrevet en rekke artikler om litterære, filosofiske og kulturhistoriske emner, som spenner fra latinamerikanske kolonitekster til lacaniansk psykoanalyse. I bokform har han blant annet gitt ut Det fjerde kontinentet. Essays om America og andre fremmede fenomener (Vigmostad \& Bjørke, 2010), om forholdet mellom essaysjangeren, kritisk teori og oppdagelsen av Amerika; en fyldig kommentert oversettelse av César Vallejos Trilce (Kolon, 2018), og den bredt anlagte Den store sangen. Kapitler av en bok om Bob Dylan (Vidarforlaget, 2016), I tillegg har han publisert mange populærvitenskapelige artikler om Bob Dylan og holdt er rekke foredrag om Dylans sanglyriske poetikk, både for et akademisk og for et bredere publikum. 


\title{
CHAPTER 7
}

\section{Hard Rain: The End of Times and Christian Modernism in the Work of Bob Dylan}

\section{Anders Thyrring Andersen}

Mag. art. i litteraturhistorie, sognepræst ved Vor Frue Kirke i Aarhus, Danmark

Master of Arts, parish priest at Vor Frue Kirke in Aarhus, Denmark

\begin{abstract}
In Denmark it is still common to characterize Bob Dylan as a left wing protest singer. However, this view is unjustified. On the contrary, Christianity is central to his songwriting, and not only in the period around 1980, when he presented himself as a believing Christian. Religiosity is not only the basis of Dylan's work from the debut in 1962 to today, but the very core of many of his songs. Sustained by a large number of quotes from, and references to, the Bible, the theme of the flood and judgement day is one of the themes running through Dylan's songs, and, based on a belief in providence, it is used to criticize secular modernity. However, this criticism is formulated in a modernistic language of images, and therefore Dylan can be characterized as a Christian modernist. He can be compared to T. S. Eliot, and uses an indirect, dialogical and dialectical method reminiscent of Søren Kierkegaard: to speak of Christian belief in the language of modernity with the purpose of re-Christening modernity.
\end{abstract}

Keywords: Christian modernism, Bible quotes, the End of Times, The Flood, Providence, dialectical method

Sammendrag: I Danmark er det stadig almindeligt at betegne Bob Dylan som en venstreorienteret protestsanger. Det er der ikke belæg for. Derimod står kristendommen helt centralt $i$ hans sangskrivning, og vel at mærke ikke kun i den periode omkring 1980, hvor han trådte frem som erklæret kristen. Det religiøse danner ikke bare grundlag for Dylans værk lige fra debuten i 1962 til i dag, men udgør kernen i mange af hans sange. Igennem et meget stort antal citater fra og henvisninger til Bibelen går som en af de røde tråde i Dylans sange temaet syndflod og dommedag -

Citation of this chapter: Andersen, A. T. (2019). Hard Rain: The End of Times and Christian Modernism in the Work of Bob Dylan. In R. W. Kvalvaag \& G. Winje (Eds.), A God of Time and Space: New Perspectives on Bob Dylan and Religion (p. 183-212). Oslo: Cappelen Damm Akademisk. https://doi.org/10.23865/noasp.74.ch7 Lisens: CC BY 4.0 
hvilket på baggrund af en forsynstro anvendes til en kritik af den sekulære modernitet. Men denne kritik formuleres i et modernistisk billedsprog, således at man kan betegne Dylan som en kristen modernist, sammenlignelig med T. S. Eliot. Han anvender en indirekte, dialogisk og dialektisk metode, som minder om Søren Kierkegaards: at tale om kristentro i modernitetens sprog, med det formål at genkristne moderniteten.

Stikord: Kristen modernisme, Bibel-citater, de sidste tider, syndflod, forsynstro, dialektisk metode

\section{Introduction}

In David Yaffe's book, Bob Dylan. Like a Complete Unknown, there is a statement that undoubtedly expresses how a very large number of people, not least in Denmark, perceive Dylan: "Indeed, if anything has been constant in Dylan's career, it's change" (Yaffe, 2011, p. xvii). Another view is expressed in Stephen H. Webb's Dylan Redeemed. From Highway 61 to Saved: "More continuities than discontinuities mark his oeuvre. As much as he kept reinventing himself, he also remained very much the same artist" (Webb, 2006, p. 62).

Yaffe is right in saying that Dylan, with his changeability, is a symptom of modernity. But in my opinion, Webb's point of view is much closer to the core, namely that Dylan is also the counterpart to modernity by virtue of something persistent. Dylan's body of work is constituted by a neverending process, but seen as a whole this process contains a number of constant elements that run through his career from its beginning to the present, and these constants constitute the themes in Dylan's production and assert in different ways, but each time with equal power, a statement, which is rephrased in song after song, on record after record.

I see at least two constants in Dylan's songs. Firstly, there is Christianity, which is the core of countless of his songs, and which manifests itself partly in the form of an astronomically large number of Bible references and allusions, and partly in the form of constantly recurring metaphors relating in particular to deluge and the end of time - metaphors that are used for a theologically motivated criticism of secular modernity. Secondly, there is a certain type of modern poetry that corresponds with T. S. Eliot's Christian and tradition-renewing poetry. In addition, Dylan has an artistic way of expressing the message of the text reminiscent of Søren Kierkegaard's. 


\section{Modernity and modernism}

Bob Dylan's songs reflect an experience of modernity: everything is in flux, everything streams. As it is succinctly put in the song "To Ramona": "Everything passes / Everything changes." The constant change must inevitably result in individuals who, like rolling stones, never have a resting place and do not possess any fixed value, but are strangers in the wilderness as expressed in the chorus of one of Dylan's most famous songs, "Like a Rolling Stone": "How does it feel / To be on your own / With no direction home / Like a complete unknown / Like a rolling stone?"

This is an existential condition that is probably filled with endless possibilities in its constant motion, and therefore can trigger a considerable amount of energy, but which also has a flip side and comes with a cost: uncertainty and disorientation, a mental suffocation as a result of the sense that nothing is permanent, that everything has fallen apart and broken in pieces. The entire song "Everything Is Broken" is one long list of broken pieces, so that virtually no earthly phenomenon is left out. However, it is not the world as such that is broken, but the modern world: "Broken hands on broken plows / Broken treaties, broken vows / [...] / People bending broken rules". This is a reference to Luke 9:57-62, where Jesus requires of his disciples that they take leave of all their belongings in order to follow him: "No man, having put his hand to the plough, and looking back, is fit for the kingdom of God." The point of "Everything Is Broken" is precisely that modernity, instead of putting a hand on the Lord's plow, itself creates and breaks all rules, with the result that everything is broken - even to an apocalyptic extent, because Dylan's song on a more general level alludes to Isa 24:18-23, the prophecy of the last judgment: "The earth is utterly broken down."

An example of how this experience of modernity on a profound level has consequences for the form of Dylan's songs is found in "Subterranean Homesick Blues”. This song denotes Dylan's stylistic shift from folk musicvoice, guitar and harmonica - to electric rock'n' roll, which would eventually have immense importance for popular music, where such a combination of rock and modern poetry would hitherto have been unthinkable.

The song is a modernist expression. Form and content are similar to each other: the quick and the febrile - yes, you could say nervous - pace 
of the music is quite similar to the compression and fragmentation in and of the text, with its continued accumulation of rhyme and breaking down of the normal syntax of the language. The breathlessness of the experience of the surrounding world has, in other words, as a formal consequence a mosaic-like description of a nervous breakdown. The surrounding modernity creates a huge pressure of alienation and paranoia. The general hopelessness evokes feelings of frustration and insecurity. And yet there is a nightmarish logic behind it all: an experience of inevitability in the midst of chaos. Look for instance at the beginning of the second stanza:

Maggie comes fleet foot

Face full of black soot

Talkin' that the heat put

Plants in the bed but

The phone's tapped anyway

Maggie says that many say

They must bust in early May

Orders from the D. A. [District Attorney]

Look out kid

Don't matter what you did

Walk on your tiptoes

Don't tie no bows (Dylan, 2014, p. 172, last line corrected after listening)

The stanza is shaped so that the listener gets the feeling that not only are all members of society subject to monitoring and eavesdropping, but nature itself is controlled by the District Attorney. Since the subject or "main character" of the text has realized this state of affairs, he can inform the "you" of the text that it really does not matter how one reacts, it will all end in the same way. As a consequence, the wisest thing to do is to go quiet about it and not form lasting relationships to other people. In the current situation the best life possible is to go into hiding and go underground - as spelled out in the title of the song.

In the midst of the seemingly chaotic structure, this is a very tightly organized text. For instance, there is a pronounced formal similarity between the stanzas: firstly, observations from a society going down the 
drain, and some of the demands this society requires of its citizens are presented, and then, secondly, follows the inquiry to the "you", the listener that is presumably parodic and useless.

Yet another characteristic of much modernist literature, an extensive intertextuality, is seen, albeit in a surprising way. "Subterranean Homesick Blues" combines the 1950's rock'n'roll musician Chuck Berry and the English 19th century poet Robert Browning! (Specifically Berry's song "Too Much Monkey Business" and Browning's poem "Up At A Villa Down In The City", from Men and Women, 1855). The purpose of the intertextuality of the song is to highlight obvious artistic preconditions for the vision of life and formality of the song. Dylan's extremely original take is the combination of the fine arts and popular culture: in the midst of pop music he expresses in a modernistic way the experience of modernity.

\section{Flood and judgment day}

However, it is still common to label Dylan as "protest singer". His breakthrough was in the beginning of the 1960s, but it made sense to call him a protest singer for only a couple of years at the most, but he is often portrayed as if he has hardly done anything worth noticing since. This is a completely unfair limitation of Dylan, who wrongly is made into something static when the truth is that he in his persistent volatility never has been tied to either a specific period or to the Left, which, especially in Denmark, has been a widely-held view.

It might make sense to call Dylan a protest singer. But it requires an understanding of what the protest that runs through the whole of his career is based on and aimed at. Dylan writes on the background of a Christian view of life and his protest concerns the secularized modernity and its ideological delusions. Already in the traditional folk and blues songs from the debut album Bob Dylan this religious aspect is central. Dylan had ample opportunity to choose to sing protest songs expressing a critique of society, but this element is almost completely absent from this album where instead a large number of Christian spirituals and gospel songs are included.

This theme is even more evident if, for example, one - on the basis of The Lyrics - realizes how many religious songs Dylan wrote in the 
beginning of his career which he did not release on his first records. A striking example is "Let Me Die in My Footsteps": "There's been rumors of war and wars that have been / The meaning of life has been lost in the wind / And some people thinking that the end is close by / 'Stead of learning to live they are learning to die". This is apparently a typical protest song about a current topic: fear of war in the early 1960s. But the basis of the criticism of Cold War society and the perspective of the song's alternative is included in the allusion to Matt. 24:6, where Jesus predicts the destruction of Jerusalem and his own second coming: "And ye shall hear of wars and rumours of wars: see that ye be not troubled: for all these things must come to pass, but the end is not yet". Everything must perish as a prerequisite for the return of Jesus and the salvation for those who persevere in the faith.

Another example is the song "Long Ago, Far Away", where the first and last stanza say: "To preach of peace and brotherhood, oh, what might be the cost / A man he did it long ago and they hung him on a cross / Long ago, far away / Those things don't happen nowadays". This is, after all, an elegant combination of social satire, protest singing, and the formulation of a Christian viewpoint, because contemporary society is criticized with the Bible as the background: the story of him who preached love and was crucified for it.

Not even on the next two Dylan records, which presumably mark the culmination of his protest songs, do the political and protest songs dominate. Around half of the songs on The Freewheelin' Bob Dylan (1963) and The Times They Are A-Changin' (1964) are neither political nor protest songs. Moreover, quite a number of the songs, which at first glance appear to be ideologically politicizing, are seen, on closer inspection, to be protesting with a much profounder, religious meaning. And finally, Dylan has himself often - both in the 196os and later - rejected interpretations of these songs as timebound and political protests.

Dylan's most famous song, "Blowin' in the Wind", is generally regarded as a political protest song, yes, even the political song of the period giving voice to the struggle for freedom, peace and civil rights in the 1960s. However, the lyrics contain a number of elements that all point in a different direction: 
How many seas must have a white dove sail

Before she sleeps in the sand?

[...]

Yes, 'n' how many years can a mountain exist

Before it's washed to the sea?

[...]

Yes 'n' how many times can a man turn his head

And pretend he just doesn't see?

[...]

Yes, 'n' how many ears must one man have

Before he can hear people cry?

[...]

The answer, my friend, is blowin' in the wind

Several allusions to the Bible are found here; e.g. to Ezek. 12:2, "Son of man, thou dwellest in the midst of a rebellious house, which have eyes to see, and see not; they have ears two hear, and hear not: for they are a rebellious house." To have eyes without seeing and ears without hearing as a sign of godlessness and lack of belief is imagery found throughout the Bible (Mark 8:18, Matt. 13:36-43 and Rev. 2:7).

The lines about the pigeon flying over the waters until it finally reaches the shore alludes to Gen. 8:8-14, which recounts that Noah releases a dove after the flood in order to discover if there is any dry land. The lines about the mountains which are washed in the sea allude to Ps. 46:1-3: "God is our refuge and strength, a very present help in trouble. Therefore will not we fear, though the earth be removed, and though the mountains be carried into the midst of the sea”. In other words, the song contains biblical imagery of an apocalyptic threat that only trust in God can avert.

Moreover the chorus of the song about the answer that is blowing in the wind alludes to the Bible; that is, to Jesus' answer to Nicodemus' question about how one is reborn in order to get into the kingdom of God: "The wind bloweth where it listeth, and thou hearest the sound thereof, but it canst not tell whence it cometh, and whither it goeth: so is every one that is born of the Spirit" (John 3:8). The answer that blows in the wind turns out to be the rebirth into eternal life by virtue of faith in Jesus 
Christ. No wonder that Dylan in 1978 stated: “'Blowin' in the Wind' has always been a spiritual" (Yaffe, 2011, p. 100).

When the song "A Hard Rain's A-Gonna Fall” was released, it was perceived as a timely protest-song against a world filled with nuclear bombs and leakage. This interpretation has been strongly opposed by Dylan in interviews: "It's not atomic rain [...] I mean some sort of end that's just got to happen" (1963), and "Line after line after line, trying to capture the feeling of nothingness” (1965; both Heylin, 1991, p. 57). Dylan obviously connects the song with something much more universal than a current political situation.

The song consists of a series of images of a dying world, an apocalypse of the last of times: modernity. Just as the imagery clearly alludes to a variety of quotes from the Bible, the "I" of the song takes on a Moses-like role as the one who comes down from the mountain to speak the will of God, and a disciple-like role as the one to praise God: "Ye are the light of the world. A city that is set on a hill cannot be hid. [...] Let your light so shine before men, that they may see your good works, and glorify your Father which is in heaven" (Matt. 5:14-16). The goal of the song is to make people aware that the rainfall is a deluge, like the one in Genesis chapters 6-8. However, the point is that although the "I" of the song knows about the order of things he cannot save anyone from the flood, not even himself. He cannot, like Christ, walk on water (Matt. 14:22-34).

Rain as a warning and image of flood and apocalypse runs like a wide stream throughout Dylan's song production - just think of the titles of his first two live recordings, Before the Flood (1974) and Hard Rain (1976). As a direct continuation of "A Hard Rain's A-Gonna Fall" one can consider the song "The Times They Are A-Changin"”. It was seen as a song of protest over the current situation - yes, even as an optimistic battle song against rulers of all kinds, and the 196os counter culture embraced it as one of its hymns. Also in this case Dylan opposed this widespread interpretation, and he made it clear that the song is not only or primarily about the difference between an older and a younger mindset: "It happened maybe that those were the only words I could find to separate aliveness from deadness. It had nothing to do with age" (McGregor, 1972, p. 10-11). 
Strictly speaking, the song is not only addressed at rulers or those in power, but is a universal encouragement and warning to all people. Metaphorically in a direct continuation of “A Hard Rain's A-Gonna Fall”, it says in the first stanza: "Come gather 'round people wherever you roam / And admit that the waters around you have grown / And accept it soon you'll be drenched to the bone / If your time to you is worth savin' / Then you better start swimmin' or you'll sink like a stone.” The flood is rising and if one does not realize that we are living in the last hours of modernity, one will drown.

Even though “The Times They Are A-Changin”" also is an apocalyptic warning, this song contains an opportunity to be saved; namely to listen to the song and follow its advice and begin to swim. The song offers an insight which can prompt the listeners to give up the life they have lived until now and stop believing that they are in charge, existentially speaking, of their lives - and instead give room for something different and better. What this might be, the last stanza is about:

The line it is drawn, the curse it is cast

The slow one now will later be fast

As the present now will later be past

The order is rapidly fadin'

And the first one now will later be last

For the times they are a-changin'

In this song, too, we see an intertextual conversation with the Bible, e.g. Matt. 19:30, Mark 10:31, Matt. 20:16, and Luke 13:30: "But many that are first shall be last; and the last shall be first." The fundamental change in the song is to be understood as the biblical inversion of all values, the reward for leaving worldly arrangements and choosing God's. Even the title of Dylan's song could be a reference to Dan. 2:21, where it is said of God: "And he changeth the times and the seasons: he removeth kings, and setteth up kings.”

The theme of Dylan's song is that each and every person must be conscious of his or her false circumstances in life and of the collapse of the secular world, characterized as it is by wealth and power - in other words, must reach a point zero, where all the usual is removed so that the real 
thing can appear. A breakdown is necessary so that real values again can be built. This is why the metaphor of the deluge is so appropriate. It refers to the crisis that erases everything apart from a belief in continuation after the point zero.

Dylan's shift from acoustic folk music to electric blues and rock is almost always interpreted as one of the most striking examples of the variability and lack of constants in his career. However, this is at most only one side of the coin. The other is that the central theme and the recurring metaphors from the first records are continued on the electric records in the middle of the 196os, only in a new musical suit or costume and with a more wild and surreal imagery.

A good example is the last two lines in the above mentioned "Subterranean Homesick Blues": “The pump don't work 'cause the vandals / Took the handles"; in other words, a continuation of the metaphor of the deluge from the early songs. The water is still rising and it is the people themselves who prevent it from being pumped away. And at the end of the second stanza of the song we have: "You don't need a weatherman / To know which way the wind blows", and at the end of the third: "Don't follow leaders / Watch the parkin' meters" - lines that are not only idiomatic bon mots, but are closely connected to the deepest themes of the song: that the wind is blowing rain, and that the remaining time in the parking meter is running out, because the end of times, the flood or deluge, is near.

Another song on the same record is "It's Alright, $\mathrm{Ma}$ (I'm Only Bleeding)", which is one of Dylan's most comprehensive and intense showdowns with modernity. The song consists of a catalogue of disgust an "I" feels by observing contemporary society where the sameness of things are overwhelming and everything is reduced to insignificance, in the sense that nothing is sacred except the rush to ensure profits and elevate oneself to a godlike status. The song is definitely a protest against the rulers in power, but the protest has a much broader and deeper purpose: an almost universal protest against an unholy world, a frustration filled with sorrow and rage aimed at the falsehood of modernity, its lies, propaganda, dishonesty, mendacity, pretense, hypocrisy and godlessness, without any sacred ideal to live up to: 
Darkness at the break of noon

Shadows even the silver spoon

The handmade blade, the child's balloon

Eclipses both the sun and moon

To understand you know too soon

There is no sense in trying

[...]

Disillusioned words like bullets bark

As human gods aim for their mark

Make everything from toy guns that spark

To flesh-colored Christs that glow in the dark

It's easy to see without looking too far

That not much is really sacred

[...]

Although the masters make the rules

For the wise men and the fools

I got nothing, Ma, to live up to

[...]

While money doesn't talk, it swears

Obscenity, who really cares

Propaganda, all is phony

The song is to be understood as an apocalyptic cry, and all its signs of the end of times alludes to Matt. 24:1-29, where Jesus predicts the destruction of Jerusalem. The destruction of the godless man-made is here rendered by the eclipse of the sun, the moon and the stars, see also the song "Desolation Row": "Now the moon is almost hidden / The stars are beginning to hide", as it is a number of places in the Bible, e.g. Amos 8:9, Joel 3:15, Isa. 13:9-11, Matt. 27:45 and Rev. 6:12.

Dylan's song opens precisely with the apocalyptic darkness at noon, where the silver spoon, honor, power, wealth, in fact everything manmade, is darkened by the self-inflicted plagues, the death of Christ and the day of judgment.

"It's Alright, Ma" concludes with the prospect of a hope: the "I" has had enough and asks a "you" if he or she might propose something different. 
This corresponds closely with those parts of the Bible the song alludes to, where the destruction, the crucifixion and the darkness on the day of judgment are preconditions for something totally different to happen: the resurrection of Jesus and the second coming.

Dylan is, in other words, to be placed within an apocalyptic and eschatological mindset, where the prevailing injustice is contrasted with the future glory, as the earthly world is directed by hidden, heavenly powers, so that the imminent end of times is always linked with a judgment, due to apostasy from God. Judgment is equal to a moral purification, which is the penalty for the apostasy, and the purification is a prerequisite for forgiveness and a restoration of the original relationship with God that shows itself in the transformation of the world to a just kingdom. The punishment often comes in the form of natural disasters, flooding, or an eclipse of the sun.

A fundamental and recurring theme is, in other words, present in Bob Dylan's production of songs from the debut to the middle of the 196os, quite unaffected by the changes he made in the period. Either one must state that Dylan never or very rarely wrote political protest songs, or that he right from the beginning was a protest singer in a much broader sense than writing ideological battle songs tied to a current political situation.

At the same time as his image as a protest singer was established, Dylan opposed this very same understanding of him. See for instance this statement in connection with the release of Another Side of Bob Dylan in 1964: “Those records I've made, I'll stand behind them, but some of that was jumping into the scene to be heard" (Heylin, 1991, p. 97). Dylan had a keen eye for his times and delivered, at least apparently, the product that the "zeitgeist" wanted. He thereby in no time achieved a position as the voice for the emerging youth rebellion, to be the darling of the civil rights movement and the Left by doing what the audience wanted to hear. Dylan's songs were only rarely political protests aimed at current events; they were, rather, apocalyptic, Bible-inspired visions and warnings about and against a time that with its ungodly pride, calls down the deluge and the day of judgment.

In his autobiography, Chronicles, Dylan repeatedly rejects the 1960s "zeitgeist" and the use of him as the voice of a new generation: "I had very 
little in common with and knew even less about a generation that I was supposed to be the voice of" (Dylan, 2004, p. 115). Dylan sees the decade and this generation as steeped in narcissism, and he enumerates sarcastically the absurd consequences of the dream of the decade of wanting to transcend all boundaries (Dylan, 2004, p. 90).

In 1986, Dylan stated in an interview with Bill Flanagan: "Most people walking around have this strange conception that they are born good, that they're really good people - but the world has just made a mess out of their lives. I have another point of view" (Webb, 2006, p. 92). That man is fundamentally good, and that evil stems from the objectionable features of society, is the 1960s viewpoint and in general the attitude of the political-ideological way of thinking: problems are created by society and can therefore be solved politically. It is not Dylan's point of view, and it was not in the 1960s or since. As Dylan stated during a concert on December 5, 1979: "You know we're living in the end times. I don't think there's anybody ... who doesn't feel that in their heart. The scriptures say, 'In the last days, perilous times shall be at hand. Men shall become lovers of their own selves. Blasphemous, heavy and highminded"' (Heylin, 1991, p. 334).

When Jesus predicts the destruction of Jerusalem, he compares the people of his own time with those who lived in the time of Noah: "For as in the days that were before the flood they were eating and drinking, marrying and giving in marriage, until the day that Noe entered into the ark, and knew not until the flood came, and took them all away" (Matthew 24:38-39). As we see, the title of Dylan's first live recording is a direct quote from this passage in the Bible. In the Bible as well as in the work of Dylan the problem is the haughty self-aggrandizement, which is the eschatological sign that we are living in the end times just before a new deluge. And precisely for that reason, the theme of deluge and its associated metaphors run like a thread through Dylan's song work. Just think of songs with titles like "Crash on the Levee / Down in the Flood", "High Water (For Charley Patton)", and "The Levee's Gonna Break". In metaphorical language steeped in the Old and New Testament Dylan tells that only a Christian inversion of all the currently reigning values will prevent the water from rising further. 
In the song "Need a Woman" it says: "Searching for the truth the way God designed it / The truth is I might drown before I find it." In his formulation of modernity and Christianity Dylan's song work really asks the question whether modernity is flooded in the deluge before it reaches faith, or whether it can escape the deluge through a repetition, or re-making, of the faith.

\section{Christian Modernism}

Bob Dylan did not really belong to the early 1960 s protest movements. In an even stronger mode he rejected the "zeitgeist" of the decade's later years - the counter culture, flower power, the generation of ' 68 - which he neither ideologically, politically, or musically was part of at any time. On the contrary, he made use of a motorcycle accident in the summer of 1966 to withdraw completely from the public. When he resurfaced with the record John Wesley Harding in December of 1967, there was here and in the records that followed a new simplicity, with even more quotations from and references to the Bible, and there was country music, exploration of traditional and popular music within the American tradition - all in all a strongly contrarian attempt to conclusively dispel the myth of him being the voice of the 6os and a mouthpiece for a generation. What is most striking in Dylan's career ever since has been the deliberate anachronism in the positions, a distancing of himself from an unbearable contemporary society, the continuing repudiation of the moral values of the times, and of the expectations of the audience. As Dylan outspokenly expressed it in an interview in USA Today, September 21, 1989:

From ' 66 on, I was trying to raise a family, and that was contrary to the whole epidemic of the ' 60 s. Most people were running away from home and trying to run away from their parents. [...] My family was more important to me than any kind of generational ' 60 s thing. Still is. To find some meaning in the sixties for me is real far-fetched ... The sixties will be forgotten. (Webb, 2006, p. 34-35)

Dylan still maintains this viewpoint in Chronicles, where he emphasizes his distance to the modern, ungodly world, and instead connects himself with tradition in a downright archaic way: God-fearing, irremovable 
moral values that modernity surely has supplanted, but which the individual can and must find (Dylan, 2004, p. 235-36).

Or, as Dylan states it artistically in one of the songs that was recorded in a basement in Woodstock in the summer of 1967, "You Ain't Goin' Nowhere": "Strap yourself to the tree with roots / You ain't goin' nowhere." While the 1960s worshipped the rootlessness and the present moment and made grand plans for a secular, humanistic future, Dylan literally went underground, and from down there he sang about being rooted, about tradition and Christian faith as oppositional tools in a forceful criticism of modernity.

It is certainly possible to argue that Dylan not only culturally and religiously, but also politically, has always been a conservative. The first person who, to my knowledge, made this claim was Steven Goldberg in the article "Bob Dylan and the Poetry of Salvation", in 1970:

His emphasis on personal, as opposed to societal, salvation could very possibly leave him feeling most at home with a political philosophy that emphazises the individual's right to be left alone to his own search for God. [...] If Dylan does tend toward conservatism, it is because conservatism, at least theoretically, mirrors his distrust of political routes to salvation. (McGregor 1972, p. 374)

A much more elaborate argument for a similar view is found in Stephen H. Webb's Dylan Redeemed (2006). Håvard Rem concludes in his article "That's Where You Belong. Den verdikonservative og flerkulturelle Bob Dylan": "Bob Dylan should not be portrayed primarily as a protest singer on the Left. First of all, Bob Dylan is a conservative artist" (Botvar, 2011, p. 71 my translation). And finally, it is stated quite remarkably in Chronicles: "I had a primitive way of looking at things and I liked country fair politics. My favorite politician was Arizona Senator Barry Goldwater, who reminded me of Tom Mix, and there wasn't any way to explain that to anybody" (Dylan, 2004, p. 283). No, for the 68-generation it must have been hard to comprehend that their hero and mouthpiece thought positively of strongly conservative Goldwater - and of Tom Mix, the most popular cowboy-star of the era of silent movies ...

In the song "All Along the Watchtower", the third and final stanza reads: "All along the watchtower, princes kept the view / While all the 
women came and went, barefoot servants, too / Outside in the distance a wildcat did growl / Two riders were approaching, the wind began to howl." All the elements of this stanza, the watchtower, the rich city, the two riders and the howling wind, allude to Isaiah 21:1-10, the prophecy of the fall of Babylon.

Thus, also "All Along the Watchtower" is to be understood as an actualization of the Bible, and as an apocalyptic prophecy. The fall of Babylon is in Dylan's song equated with the last days of modernity, brought forth by godlessness, warned of by the wind, and announced by the two riders. Who are these riders who in the song are called "the joker" and "the thief"? As Jesper Tang has pointed out in Bob Dylan smiler! (Tang, 1972, p. 167-68), a joker in a game is the one who does not have a fixed value beforehand. The joker is therefore without identity, or rather the one who can freely seize and exchange a number of identities. But if the joker is liberated from the fixed hierarchy of values, this does not mean that he is free from being part of the game. Freedom is thus only being free to a never- ending play of roles, which, keeping in mind its endless possibilities and options, involves the risk of existential confusion and rootlessness.

It is, in other words, possible to identify the joker with Dylan himself and interpret the song's first stanza as a text about his songwriting: “'There must be some way out of here,' said the joker to the thief / 'There's too much confusion, I can't get no relief / Businessmen, they drink my wine, plowmen dig my earth / None of them along the line know what any of it is worth"'. Dylan knows of, and can distance himself from, the values of modernity. To approach the constantly changing nature of modernity with constant change has been Dylan's method, but the risk of using it is twofold. Firstly, that one is not interpreted and understood, and is therefore merely seen as yet another expression of that very modernity that one wanted to challenge. And secondly, that one gets lost in the labyrinth and becomes a part of it, rather than finding a way through it. Dylan the Jokerman knows of a way out, but cannot find it himself.

His companion, however, can. The thief says: "No reason to get excited,' the thief, he kindly spoke / 'There are many here among us who feel that life is but a joke / But you and I, we've been through that, and 
this is not our fate / So let us not talk falsely now, the hour is getting late"'. The thief, unlike the joker, is neither confused nor desperate. His insight and viewpoint are that the chaos of modernity is not a fixed destiny, but something one can get through by speaking the truth at the end of time. In other words, the thief has gained an identity by virtue of his criticism of modernity and thus has a set of values to act upon.

This is not strange at all, because the thief in Dylan's song is equated with Christ. After the prediction of the destruction of Jerusalem, Jesus predicts his own return and demands vigilance from his disciples, as well as likening himself to a thief who comes at night (Matt. 24:42-44). In addition, the song contains a reference to Revelation: "Blessed is he that readeth, and they that hear the words of this prophecy, and keep those things which are written therein: for the time is at hand" (1:3 - cf. Matthew 26:45, where Jesus, just before his capture, says to the disciples: "[...] behold, the hour is at hand"), that is, "the hour is getting late", as the hour generally speaking is in Revelation, where the fall of Babylon is a general symbol of the godless confusion just before the day of judgment.

In conclusion, one can say that "All Along the Watchtower" is a song about how the Christian artist with his art attempts to convert the secularized modernity. While being a modernist expression of contemporary times, Dylan's songs are simultaneously a critique of the "zeitgeist". Dylan uses the language of modernity and elaborates on it in a dialectical way in order to contradict the view of life it is usually associated with, which is why it is reasonable to call Dylan a Christian modernist.

Artists of this kind can be difficult to characterize and recognize, primarily because one is influenced by the erroneous and reductive idea from secular modernity that it is impossible to be both religious and modern at the same time. That is why Dylan is often framed as belonging only to the political protest of the 1960s, and why his religiousness is usually isolated to the years around 1980, the time when he in a very direct way declared himself to be a Christian.

But Dylan's song work is in all its phases religious and has deep roots in tradition, as well as being part of the contemporary situation both thematically and aesthetically. He is an artist who finds himself in the tension between tradition and modernity, between religious faith and the 
secular world, and has on this basis produced a song work that combines a Christian view of life with a modernist strategy, aesthetically speaking. There is, in other words, not only one kind of modernism, as is often claimed in, for example, Denmark, namely the one sanctioned by the secular segment of society, for there exist at the same time other kinds of modernism. It can be argued that roughly speaking two mainstreams in the many kinds of modernism in the twentieth century can be found. Dylan's kind of modernism is far removed from the one that is often connected with the American poet Ezra Pound, which might be described as the avant-garde breaking down of tradition, and is more in line with the one that is represented by the Anglo-American poet T. S. Eliot, restorative modernism. In the essay "Tradition and The Practice of Poetry" (1936) Eliot states that the task of poetry is always to make something old into something new. Neither Eliot nor Dylan chooses or breaks with tradition; tradition is something to elaborate on and renew. Understood this way, modernism is not a break with tradition, but a part of it. That Dylan knows about this discussion of modernism is evident from "Desolation Row", in the lines: "And Ezra Pound and T. S. Eliot / Fighting in the captain's tower".

It is obvious that Dylan as a person and an artist represents a religiously motivated resistance against modernity, but as with Eliot it is a resistance that is formulated in a modern way, a protest, that is so much stronger because it is expressed in a contemporary idiom. Eliot's and Dylan's modernism are at the same time a protest against secular modernity and a positive testimony to the possibility of faith even during this time. Dylan's originality is not least that he as a Christian modernist is capable of continuing, in an innovative and contemporary way, what is Christian, and of reshaping tradition into modernity.

In Dylan's extensive use of elements of tradition - loans, reuse, allusions - he makes them his own, in recontextualizing them through a new interpretation of the material in a new context. The melting pot his songs thereby turn into is an intertextual modernism that is comparable to Eliot's: the intention is not to break away from tradition, but on the other hand to bring together elements from various parts of tradition in an unconventional and personal way. In other words: tradition in transition. 


\section{Christian protest}

For a period around 1980 Bob Dylan emerged as a Christian and released some records that were bluntly edifying and openly sermonizing. This period in Dylan's career is usually called "the Christian phase". But the point is still that Dylan's songs before and after this time also are religious, and that the difference mainly is that Dylan is more directly outspoken, the Christian faith is presented as an open confession instead of something that must be interpreted from the many allusions. Similarly, Dylan's songs from this period are webs of biblical quotes; there are indeed several songs in which almost every single word is taken from the Bible. The proselytizing Christian albums are thus not departures from, but continuations of, the theme and method of Dylan's older songs: what had hitherto been implicit is now explicit.

The transitional album is generally considered to be Street-Legal (1978). What the material-secular world has to offer is not enough, just as physical love is not. In the song "Señor" (which in Spanish also means God) it is thus stated in the last stanza: "Señor, señor, let's overturn these tables / Disconnect these cables / This place don't make sense to me no more / Can you tell me what we're waiting for, señor?". The song is a prayer that God will intervene as soon as possible in a world that makes no sense. The stanza contains an allusion to Matthew and the cleansing of the Temple (21: 12-13). Modernity has transformed the house of God, indeed the whole world, to a marketplace and a den of thieves, and the "I" waits for God to cleanse it all.

The following album, Slow Train Coming (1979), includes the song "When You Gonna Wake Up?", which is an all-encompassing critique of the secular world, but at the same time even more direct in pointing to an alternative. All human organizations are fraudulent, the ways of thinking poison, rightwing as well as leftwing ideologies are stifling, innocence is thrown in jail, churches and schools, doctors and the laws: everything is broken and everything destroys, while modernity is chasing material wealth and continues to dream on in its illusions of self-glorification. The only thing in the song that is not a fraud or an emptiness is God who sent his Son to us, so that he could die for us and thus atone for our sins. One of the countless biblical quotes in the song is a motif and theme, from 
its title to its refrain: "[...] I know thy works, that thou hast a name that thou livest, and art dead. Be watchful, and strengthen the things which remain, that are ready to die: for I have not found thy works perfect before God. Remember therefore how thou hast received and heard, and hold fast, and repent. If therefore thou shalt not watch, I will come on thee as a thief, and thou shalt not know what hour I will come upon thee" (Rev. 3: 1-3). At this late hour, and just prior to divine judgement of humankind's inadequacies, it is important for modernity to wake up from the death of disbelief.

The songs on these records are certainly protest songs, and as such among the most implacable Dylan has ever written. Indeed, he was and remained a protest singer, but undeniably in a much more profound way than the protest of the 1960 os generation, because Dylan, on a Christian basis, knows man's weakness.

This is why it says in the song "Gotta Serve Somebody" from the same album: "You may be a construction worker working on a home / You may be living in a mansion, you might live in a dome / [...] // But you're gonna have to serve somebody." To serve is crucial because the humble service unites all and breaks down all the constructions of humankind.

Therefore, nothing could hardly be more wrong than the contemporary reception of Dylan's "Christian phase" and the insistence that he, from a self-righteous position, was about to judge some people and acquit others. On the contrary, everything existing is criticized with an unprecedented ferocity, because all are equal in the self-inflicted flood, and in the light of God's judgment all human deeds are indicted. And the choice is extremely simple: "Well, it may be the devil or it may be the Lord / But you're gonna have to serve somebody", an allusion to Matt. 6:24, "No man can serve two masters: for either he will hate the one, and love the other; or else he will hold to the one, and despise the other. Ye cannot serve God and mammon."

History repeats itself. Just like in 1965, when Dylan substituted the folk music slogans with electrified modernism, and in the late 196os when he in a contrarian manner and in opposition to the hippies, the counter culture, and the generation of 1968 moved to the countryside and recorded country music and pop music: he was yelled at. His Christianity was, 
especially in liberal and academic circles in the US and in supposedly open-minded Denmark, called fundamentalist and reactionary, though he had never before been so openly and relentlessly critical of society.

That Christianity, after the openly sermonizing albums, has not been preached in the same straightforward and missionary way since has led to the widespread assumption that Bob Dylan is no longer a Christian believer and that because of this his songs express disillusionment. But Christianity in no way disappeared from Dylan's songs; he just returned to the more indirect, alluding method. In an interview with The New York Times on 28th September 1997, Dylan said:

Those old songs are my lexicon and my prayer book. All my beliefs come out of those old songs, literally [...]. You can find all my philosophy in those old songs. I believe in a God of time and space, but if people ask me about that, my impulse is to point them back toward those songs. I believe in Hank Williams singing "I Saw the Light." I've seen the light, too. (Dettmar, 2009, p. 24)

Dylan was probably having a personal crisis in the mid-1980s, and one of the consequences was the most fruitless and uninspired years in his career. But it is characteristic that when Dylan makes a comeback with Oh Mercy in 1989, it is - with the exception of the albums containing direct preaching from around 1980 - perhaps the most pronounced Christian album of his entire production. On Oh Mercy, there is, of course, the customary apocalyptic hatred of modernity, not least represented by the opening song "Political World", which is a tightlipped denunciation of any secular ideology. But the album also includes a number of soul-searching and evangelical songs which bear witness to Christian belief and a more graceful recognition that sin is not only culpable, but also an inevitable part of human existence, for example in the song "Ring Them Bells". In this song the bells are ringing just before judgment day so the sheep can be separated from the goats - and so that the sleeping paganism in modernity can be awakened and come to believe in something else than the rush hour and worldly affairs. The mountains in the last days of modernity and paganism are filled with doomed and lost sheep. It is obvious that the song is yet another apocalyptic warning to secular modernity, which with its disbelief evokes the apocalypse 
and the judgment: man has shattered the difference between good and evil. However, at the same time the song expresses hope in that it not only describes the moment just before the end of time, but also circles around the possibility of awakening and conversion: that the Kingdom of Heaven is near, salvation through the good shepherd, and the return of Jesus Christ.

The fact that the metaphors of the flood were being continued on the albums of the following decade has already been mentioned. What remains to be stated is that the theme of Dylan's albums the last 15-20 years has been that the carnal love and the pursuit of earthly happiness might seize the mind, but never fulfill and always disappoint and hurt, since all human capacities and ideas fall short when it comes to what is essential. This is why it is vital to seek God before the judgement is delivered (see for example "Sugar Baby").

\section{Confidence and Paradise}

While, as we have seen, one constantly recurring theme in Dylan's song work is Christian belief with an emphasis on the judgment aspect, often expressed through metaphors of flood and judgment, another aspect of Christian faith is also constantly visible, namely the idea of paradise, frequently expressed in metaphors of mountains.

On the album Shot of Love (1981) there is the masterful, modern hymn "Every Grain of Sand". The song is not like most of the other songs from this period. It is not a reflection of direct edification, but is about moving towards the Christian faith by going through doubt. The confession is linked with distress and need, the temptation is latent, just as the sound of the divine presence in the world sometimes turns out to be just the sound of oneself, of one's desire to experience the meaning and cohesion of everything. The Christian faith is depicted not as a static result, but as a living process. The song thus gives the listener and modernity a point of identification in that everything changes, that nothing lasts. However, the song also claims that everything can always be repeated on the other side of change and doubt, because of the belief that behind all the preliminary appearances an eternal Creator is present in everything we meet and 
experience, and that nothing therefore is without meaning or purpose. See the allusion in the song to Matt. 10:30, "But the very hairs of your head are all numbered."

The encounter with God's creation is in this way the renewal of the faith that individuals cannot by themselves maintain. See the last line and its allusion to Matt. 10:26-33, the call for fearlessness on the basis that not even a sparrow "shall not fall on the ground without your Father". This is the opposite of the situation in the beginning of the song, the flood of tears from man himself drowning any hope - and which very well could allude to Psalms: "The rivers of waters run down mine eyes, because they keep not thy law" (119:136).

Thus, if doubt is written into the song, the root of this doubt is placed with the self, that is, man, and not as a doubt of the existence of God. It is a song about man's inability to always maintain his faith, not a song about the non-existence of God. When the person reaches out, she or he finds God. Even in "the fury of the moment," in those moments where life hurts, or where it feels like God is holding back his grace, the person in the song feels the presence of God.

The song's title and the whole theme allude to Ps. 139:17-18: "How precious also are thy thoughts unto me, O God! how great is the sum of them! If I should count them, they are more in number than the sand." This conclusion is reached as the psalmist recognizes that God sees through him, is always close to him, and that God is the one for whom everything is bright, and the one who formed him in secret and puts his whole life right. Man is not able to comprehend the omnipresence of God, but can only approach in the shape of faith: "Thou hast beset me behind and before, and laid thine hand upon me. Such knowledge is too wonderful for me; it is high, I cannot attain unto it." (Ps. 139:5-6). In other words, "Every Grain of Sand" is a song that expresses faith in divine providence. The belief that everything is happening for a cause that is all-encompassing, but in turn completely or almost hidden from man, and which can therefore only be relied upon through faith. The meaning and the sacred found in the everyday life, also in adversity and suffering, because God has created it all, it is all part of his plan, and thus everything is a manifestation of God's ruling and grace. 
Based on providence it is no wonder that Dylan has always had the view that God is everywhere, behind and in creation. In an interview with Neil Hickey in TV Guide, September 11, 1976, Dylan said: "I can see God in a daisy, - in the wind and the rain. I see creation just about everywhere" (Thomsen \& Schnack, 1998, p. 110). This belief in God's omnipresence in creation is expressed in the early song "Lay Down Your Weary Tune", in which humans are invited to stop their own weary song, and instead find rest and meaning in the song God sings to us through the creation.

It is striking in this context that Dylan's visions of doomsday are very often expressed in images from nature: flood, rain, wind and thunder. But also his visions of paradise are expressed in images from nature. A good example is the final song of Time Out of Mind, the long "Highlands". A portion of this song is about being distanced from, and without contact with, the immediate environment. The mundane everyday reality of modernity feels like a rat race, a stale monotony, a jail of opacity, where nothing seems to have context or be meaningful, and where the person feels lost, also as a result of having made the wrong choices.

A second layer in this song of distance and self-criticism circles around the longing for otherness, another place or state of mind in which everything makes sense; a meaning that is not created by humans, but which presents itself to the person in the song through images from nature. The entire song bears witness to the notion that its title "Highlands" does not refer to any specific geographical location, but to paradise, understood as a transcendental part of the mind and/or as eternity. It is obvious that this is an allusion to a poem by Robert Burns, "My Heart's in the Highlands" (1790). In Dylan's song the metaphor of the Highlands is expanded to include the paradisiacal, whether that is what the heart belongs to in this world, or it is the home that, according to the faith of the I-person, awaits man on the other side of death. The Highlands are, in other words, a metaphor for religious longing. It is striking that the paradisiacal finds its image in the Highlands - that is, the opposite of the lowlands, which are the first to be inundated by the great flood, in the day of judgment.

Just as the flood flows through Dylan's songs, so there are many places where the dream of the paradisiacal place or the paradisiacal state of 
mind is linked to mountains. The early song "Let Me Die in My Footsteps", which as mentioned above is a Christian apocalyptic critique of contemporary society, also, in opposition to the fallen world of today, contains the following dream: "Let me drink from the waters where the mountain streams flood / Let the smell of wildflowers flow free through my blood / Let me sleep in your meadows with the green grassy leaves". In the song "Time Passes Slowly" Dylan sings: "Time passes slowly up here in the mountains / We sat beside bridges and walked beside fountains / Catch the wild fishes that float through the stream". In the song "Hurricane" this imagination of paradise resurfaces, here disguised as the boxer Rubin Carter's longing: "Up to some paradise / Where the trout streams flow and the air is nice". In this Arcadia, a pastoral ideal landscape, time has stopped and the water is under control - as opposed to the rest of the modern world, where the water level relentlessly rises, and time is ticking towards the end of time.

It is therefore quite remarkable that God in the prayer "Father of Night" is God for everything, night as well as day, darkness and light, the mountains and the rain, love and suffering. The God who is prayed to in Dylan's hymn has created everything in nature and inhabits our dreams, hearts and memories, and this God controls the rivers (referring to Proverbs 21: 1, “The king's heart is in the hand of the LORD, as the rivers of water: he turneth it whithersoever he will"), as well as the rain and the flood, but also love, mountains and grace.

\section{The indirect method}

With the box set Biograph from 1985 come two booklets, which among other things consist of Cameron Crowe's interview with Bob Dylan, where he applies shorter or longer remarks to a number of his songs. His comment on "Every Grain of Sand" is:

Everything is crooked now and the signs all point you the wrong way - it's like we're living at the time of the Tower of Babel, all our tongues are confused. $[\ldots]$ it comes from the Bible, so it can be cast off as being too quote religious. Make something religious and people don't have to deal with it, they can say it's 
irrelevant. 'Repent, the Kingdom of God is at hand.' That scares the shit out of people. They'd like to avoid that. [...] There does come a time, though, when you have to face the facts and the truth is true whether you wanna believe it or not, it doesn't need you to make it true... That lie about everybody having their own truth inside of them has done a lot of damage and made people crazy. Did you ever hear that to conquer your enemy, you must repent first, fall down on your knees and beg for mercy? [...] I do know that God hates a proud look. [...] Maybe in the '90's or possibly in the next century people will look upon the ' 80 's as the age of masturbation, when it was taken to the limit [...]. I like to keep my values scripturally straight though - I like to stay part of that stuff that don't change. [...] What's changed? When did Abraham break his father's idols. I think it was last Tuesday. God is still the judge and the devil still rules the world so what's different? (Crowe, 1985, p. 48-49)

First, those comments originate from the time where Dylan, according to widespread belief deeply disillusioned, had left Christianity - which is clearly just not the case.

Secondly, Dylan as usual puts forth his scathing criticism of secular modernity with the small change that its image, the godless Babylon, is supplemented by the Tower of Babel, the high rising tower that mankind, according to Genesis chapter 11, built so as not to be scattered. But to prevent the people from thus breaking the law of God, God confused their mother tongues and scattered them all over the earth. Dylan's point is that modern man's feeling of greatness is ungodly masturbation, and that the modern view that every human being are in possession of the truth within himself or herself is a dangerous expression of madness - because the only truth in a Christian sense is the one that God has bestowed upon us through Jesus Christ, and therefore modernity should not cultivate pride, but humbly pray.

Thirdly, Dylan expresses the view that time, history and development are, when it comes to fundamental things, categories that can be visual deceptions, since nothing changes: God has always been and still is the judge, and the devil still reigns in the earthly world. In some sense Dylan himself is a man of modernity, but a man who, because of his Christian belief, longs to be part of a world which does not change, but is eternal and absolute - that is, is not subject to the changes and relativity of modernity. He also claims that the truth of human existence is not modernity's, 
that everything floats and streams, but Christianity's, that everything is created by the eternal God.

Fourthly, Dylan more than suggests the reason for, and nature of, the particular way in which he has artistically communicated Christianity to the public. Since modernity neither believes in, nor wants to see, life in the light of religion, it rejects any direct talk of what Christianity is and what it requires. It is, therefore, in the context of modernity better to speak indirectly about the Christian point of view.

For that reason Dylan has used a dialectical method throughout most of his career. In order to make modern, secularized people interested in being part of the conversation of what Christian faith is, he has spoken of Christian faith in the language of modernity. But certainly with the aim of making modernity Christian again.

In this manner, Dylan's view, theme and method are comparable to those of Danish theologian Søren Kierkegaard (1813-55), since he too expressed his Christian views on life to a secular modernity by translating the Christian into the form and language of modernity. The method is about leading modern man away from the place where he or she is to another place. But that is precisely why everything must begin from the point where they are. Thus, one begins where the person who needs help is, and seduces to what is Christian. This is a method which Kierkegaard in Om min Forfatter-Virksomhed (1851) describes as "deceiving into Truth" (Kierkegaard, 1997-2012, vol. 13: 13, "at bedrage ind i det Sande").

For both Kierkegaard and Dylan, in other words, the nature of the contact with the individual reader or listener is crucial, and a very large number of songs from throughout Dylan's career are shaped like inquiries, in that an "I" verbally reaches out to a "you" and tries to establish a dialogue. The dialogic request to the listener is thus another constant in Dylan's songs, but it manifests itself in very different ways. One could again point to "Blowin' in the Wind" where the answers indeed do blow in the wind, but potentially are present in the questions themselves, as the song by asking them indirectly calls on the listener to consider the answer.

The song "With God on Our Side" (The Times They Are A-Changin') seems, at first acquaintance, to be a one-dimensional protest song where the good guys and the bad guys, right and wrong, are established from 
the beginning. But toward the end the song suddenly surprises the listener profoundly in that there is an allusion to Luke 22: 48:

\author{
Through many dark hour \\ I've been thinkin' about this \\ That Jesus Christ was \\ Betrayed by a kiss \\ But I can't think of you \\ You'll have to decide \\ Whether Judas Iscariot \\ Had God on his side
}

The poet neither can nor wants to answer on the listener's behalf, but can ask the question, and thus try to make the individual listener think and act for himself. Is Judas an example of the abuse of free will? Or is providence leading Judas to the betrayal as a necessary element in the story of Jesus Christ: no death, no resurrection? And if Judas had God on his side, who doesn't?

This method of making the listener think and act for himself Dylan describes in the song "Lay, Lady, Lay" (Nashville Skyline, 1969), which appears, at first listen, to be just a macho-like love song in country style, but on closer inspection reveals itself as a meta-song about Dylan's special relationship to his listener: "Lay, lady, lay, lay across my big brass bed / Whatever colors you have in your mind / I'll show them to you and you'll see them shine". To listen to Dylan is to be seduced - not in a passive sense as is most often seen in modern art and entertainment, but on the contrary to be activated and visible in one's understanding of, and relation to, the text.

It is therefore not possible to remain neutral to Bob Dylan's songs, because you learn something about yourself by listening to them.

\title{
Literature
}

Andersen, A. T. (2002). At forføre til tavshed. Søren Kierkegaard proesenteret. København: Dansklærerforeningen.

Andersen, A. T. (2006). Knockin' On Heaven's Door. Om Bob Dylans kristne modernisme. In D. Bugge (Ed.), Geni og apostel. Litteratur og teologi (p. 111-128). København: Anis. 
Andersen, A. T. (2013). Before the Flood. Apokalypse og kristen modernisme hos Bob Dylan. In A-M. Mai, A. T. Andersen, F. G. Andersen \& H. Detering (Eds.): Hvor dejlige havfruer svømmer. Om Bob Dylans digtning (151-208). Odense: Syddansk Universitetsforlag.

Botvar, P. K., Kvalvaag, R. W., \& Aasgaard, R. (Eds.). (2011). Mannen, myten og musikken. Oslo: Dreyers Forlag.

Crowe, C. (1985). Text and Liner Notes, in Bob Dylan: Biograph, Columbia Records.

Dettmar, K. J. H. (Ed.). (2009). The Cambridge Companion to Bob Dylan. Cambridge and New York: Cambridge University Press.

Dylan, B. (2004). Chronicles. Volume One. London: Simon \& Schuster.

Dylan, B. (2014) [2004]. The Lyrics. London: Simon \& Schuster.

Gray, M. (2004) [200o]. Song \& Dance Man III. The Art of Bob Dylan. London and New York: Continuum.

Hallbäck, G., Jensen, H. J. L., \& Wiberg, B. (Eds.). (1998). Gads Bibel Leksikon. Vol. 1-2, København: Gads Forlag.

Heylin, C. (1991). Dylan. Behind the Shades. London: Penguin.

Kierkegaard, S. (1997-2012). Skrifter. Vol. 1-28, København: Gads Forlag.

McGregor, C. (Ed.). (1972). Bob Dylan. A Retrospective. New York: Morrow.

Tang, J. (1972). Bob Dylan smiler!. København: Borgen.

The Official King James Bible Online. www.kingjamesbible.com

Thomsen, C. B., \& Schnack, A. (1998). Bob Dylan - En guide til hans plader.

København: Høst \& Søn.

Webb, S. H. (2006). Dylan Redeemed. From Highway 61 to Saved. New York and London: Continuum.

Yaffe, D. (2011). Bob Dylan. Like a Complete Unknown. New Haven and London: Yale University Press.

\section{Author description}

Anders Thyrring Andersen is Master of Arts, Comparative Literature, parish priest at Vor Frue Kirke in Aarhus, Denmark. Publications on Bob Dylan: Hvor dejlige havfruer svømmer. Om Bob Dylans digtning, Syddansk Universitetsforlag 2013; “Knockin' On Heaven's Door”, Geni og apostel. Litteratur og teologi, Anis 2006; "En fortjent Nobelpris", Studenterkredsen no. 1, January 2019; a number of newspaper articles and appearances on National Public Radio. Has written a lot about the relationship between literature and Christianity, among other titles Polsponding. Forførelse og dialog hos Martin A. Hansen, Gyldendal 2011, and At forføre til tavshed. 
Søren Kierkegaard prosenteret, Dansklærerforeningen 2002. Recipient of Blicherprisen 2009 and Martin A. Hansen Prisen 2011.

\section{Forfatteromtale}

Anders Thyrring Andersen er Mag.art. i litteraturhistorie, sognepræst ved Vor Frue Kirke i Aarhus, Danmark. Publikationer vedr. Bob Dylan: Hvor dejlige havfruer svømmer. Om Bob Dylans digtning, Syddansk Universitetsforlag 2013; "Knockin' On Heaven's Door», Geni og apostel. Litteratur og teologi, Anis 2006; "En fortjent Nobelpris", Studenterkredsen nr. 1, januar 2019; flere avisartikler og medvirken i adskillige radioudsendelser. Har skrevet meget om forholdet mellem litteratur og kristendom, herunder Polspanding. Forførelse og dialog hos Martin A. Hansen, Gyldendal 2011, og At forføre til tavshed. Søren Kierkegaard prosenteret, Dansklærerforeningen 2002. Modtager af Blicherprisen 2009 og Martin A. Hansen Prisen 2011. 


\title{
CHAPTER 8
}

\section{Bob Dylan's Ten Commandments - a Method for Personal Transformation}

\author{
Petter Fiskum Myhr \\ Direktør for Trondheim Internasjonale Olavsfest \\ Director of Trondheim International Olavsfest
}

\begin{abstract}
Over the years, Bob Dylan has been able to go through many changes as an artist and as a person - always flexible, always in touch with his life, his aging, always true to himself, but not to his audience. While so many of us seem to stick to our old ways, Dylan has had this rare ability to keep on moving on, like a rolling stone. How has this been possible? In this chapter I present what I call Bob Dylan's method for personal transformation. I have found ten commandments, or ten rules, that Dylan seems to be following. To show the importance of the commandments I assess Dylan's method for personal transformation in relation to Philip Salim Francis's research among 82 Evangelicals who underwent a sea-change of religious identity through the intervention of arts, published in the book When Art Disrupts Religion. Bob Dylan's ten commandments are not only 10 great tools for a creative life, they are also a great roadmap for a flexible religious life and good medicine against all sorts of fundamentalism.
\end{abstract}

Keywords: Dylan, transformation, art, religion, creativity

Sammendrag: Gjennom hele sin lange karriere har Bob Dylan hatt en sjelden evne til å forandre seg - alltid i nær kontakt med livets mange faser, alltid tro mot kunsten, men ikke mot fansen. Mens de fleste av oss nøyer oss med å gå i gamle spor, har Bob Dylan brutt opp, forlatt dem som hyller ham, dem som mener de trenger ham, dem som til og med tilber ham, og søkt nye veier. Hvordan har dette vært mulig? I dette kapitlet vil jeg presentere det jeg kaller Bob Dylans metode for forandring. Jeg har funnet ti bud, eller ti regler, som Bob Dylan har forholdt seg til gjennom livet og karrieren. For å vise betydningen av disse budene, holder jeg dem opp mot Philip Salim Francis forskning blant 82 evangelikale kristne, som alle har fått sin religiøse identitet forvandlet etter å ha blitt eksponert for kunst. Dette skriver Francis om i boka When Art Disrupts Religion. Bob Dylans

Citation of this chapter: Myhr, P. F. (2019). Bob Dylan's Ten Commandments - a Method for Personal Transformation. In R. W. Kvalvaag \& G. Winje (Eds.), A God of Time and Space: New Perspectives on Bob Dylan and Religion (p. 213-233). Oslo: Cappelen Damm Akademisk. https://doi.org/10.23865/noasp.74.ch8

Lisens: CC BY 4.0 
ti bud er ikke bare ti gode verktøy for et kreativt liv, det er også en medisin mot alle former for fundamentalisme og samtidig en god hjelp for den som ønsker å leve et fleksibelt religiøst liv.

Nøkkelord: Dylan, forvandling, kunst, religion, kreativitet

The claim ... is that the arts possess a unique capacity to unsettle our entrenched ways of thinking and believing; that the arts, like nothing else, can open our minds to fresh ideas and alternate perspectives.

-Francis (2017, p. 5)

And be not conformed to this world: but be ye transformed by the renewing of your mind...

-Romans (12:2)

\section{Introduction}

Bob Dylan is like Jesus in some ways. Dylan and Jesus are both Jews, they are both considered to be prophets, they both have a lot of followers - but, much more essentially, they are both complex, revolutionary and contradictory personalities to such a degree that you cannot pin them down. They do not add up to one character. In the same way that you can always find your own Jesus - usually the Jesus that is a mirror of your own values and conception of the world - you can always find your own Dylan.

In the early years of Dylan's career many people connected to his political finger-pointing songs, while others connected to Another Side of Bob Dylan, with more poetic and personal songs. These were two different fan groups, with different interests. Later some people connected to the provocative rock artist, while others connected to the Nashville Skyline country singer. Both these groups disliked each other for being, respectively, radical and conservative. Even later, a completely different group of people connected to the born again Christian Dylan, although many of the old fan groups hated this transformation. Some of them stopped following their prophet, their rock god, their super hero, their most important mediator (to use a term from René Girard, the philosopher of mimetic desire). 
While Joan Baez stayed behind in the folk movement, while The Rolling Stones stayed behind in the rock movement, Bob Dylan kept on moving, always flexible, always in touch with his life, his aging, always true to himself, but not to his audience. The followers - they are still legion, but they are diverse; most of them are still hanging on to their flock, their own familiar music congregation.

Is it possible that none of these groups get Bob Dylan? Maybe they only relate to a small part of him, the part that they fell in love with in their youth. Instead of learning from Dylan's example, to keep on moving on, like a rolling stone, they stay behind with what they found so many years ago. Instead of being alert, instead of seeing reality in the present moment, instead of searching for new experiences, new feelings and reflections, they are satisfied with recycling old feelings, fading memories, from when they listened to Bob Dylan's music in another lifetime, when their world was young.

I believe this. I believe that most people have failed to understand the essence of Bob Dylan's artistic project, and I think that Dylan himself is painfully aware of this, when he says: “I don't think I'm gonna be really understood until maybe 100 years from now. Because what I've done and what I'm doing, nobody else does or has done" (The Sunday Times, July 1, 1984).

Music, literature, art - no matter how great - together make up a force that can be used to achieve two opposite things. On the one hand, you can use it to preserve and protect your identity, your notion about yourself and the world. On the other hand, you can use it to widen your world (to use a slogan from Turkish Airlines). The ultimate goal for all great art should be to transform or widen our limited world view - or to put it even more strongly, as Dylan once stated: "Art should not reflect culture; art should subvert culture" (Sloman, 2002, vii).

When the 19-year-old Bob Dylan came to New York in 1961, he had no interest in the daytime show at Café Wha?, because it was "nothing that would change your view of the world" (Dylan, 2004, p. 12). Later, Dylan expressed the artist's obligation by quoting Henry Miller, who once said: "The role of an artist is to inoculate the world with disillusionment" (Cott, 2006, p. 224).

How do you do that? It can be done in many ways, of course, but you can learn a lot about this by studying Bob Dylan's method through his 
long career. I have found ten rules, or ten commandments, that Dylan seems to be following. Those commandments are not only ten great rules for a creative life; they are also a great roadmap for a flexible religious life and good medicine against all sorts of fundamentalism.

\section{When art disrupts religion}

There are always some people who need to systemize and categorize the world and people's lives. Some of them are in positions of power with lots of education. They name things; they make dichotomies; they make clean borders, so that they are able to control power and keep things pure. This is a constant temptation for all of us - namely, to seek and to worship the pure. We do this not only in religion, but in art, in music, in business, in relationships. It's a pity, because everything that is unable to change, dies.

Philip Salim Francis, who is an Assistant Professor of Religious Studies at Manhattan College and Mellon Postdoctoral Fellow in the Humanities at the University of Pennsylvania Humanities Forum, has explored the shifting interrelationship of religion, art, and sexuality in the modern West. In his book, When Art Disrupts Religion, Francis presents the narrative of 82 Evangelicals who underwent a sea-change of religious identity through the intervention of the arts. Likewise, in the book's afterword the author tells us his personal story from when he was fourteen years old. While rummaging through a storage compartment in the family's house, Francis found a bundle of old records: "When I brought the records into the light, and wiped away the dust ... the album covers spoke to me immediately, ushered me into a different world, especially a record entitled Bringing It All Back Home" (Francis, 2017, p. 147).

He started to reflect upon why these Dylan records from the '6os and early '7os had survived his parents' conversion to evangelical Christianity in the 1980s. He will never know the answer, but the records made their impact: "Because these Dylan records were saved, a glimpse of that disruptive beauty, staggering authenticity, and defamiliarizing poetry came to my life - and into the lives of my brothers, as we gathered around the record player for secret listening sessions when my parents weren't 
around. To this day, we remain Dylan devotees - with an evangelical fervor, if not an evangelical faith" (Francis, 2017, p. 148).

Philip Salim Francis's book, When Art Disrupts Religion, shows how the evangelical mind uses different methods of identity preservation. For instance, he writes that "fundamentalist thinking is often characterized as a need for absolute certainty about the ultimate meaning of life, a tendency to draw hard lines of division between insiders and outsiders, a proneness toward black-and-white thinking, and a penchant for idealizing a past, golden age of the community" (Francis, 2017, p. 9). This need for absolute certainty makes for a general suspicion towards ambivalence, which is so essential to modern art, and also to innovation and change. It takes a lot of practice to achieve absolute certainty. For evangelicals, this practice includes child evangelism, the immorality of doubt, and fear of hell. To keep your sense of certainty, you are inclined to cultivate a suspicion toward regular workings of the mind, like questioning and doubting.

What art can offer - in contradiction to this - is practices of uncertainty. The arts unsettle certainty, while comforting the uncertain. Or, as David Foster Wallace once observed: “Good fiction's job is to comfort the disturbed and disturb the comfortable" (Francis, 2017, p. 68). Art can give form to the formless; it can give meaning where there is no meaning to be found, because it can give a truthful expression of the lack of meaning. Rosanne Cash, who grew up with a very Catholic mother and a famous Baptist father, says in her memoirs: "We all need art and music like we need blood and oxygen. The more exploitative, numbing, and assaulting popular culture becomes, the more we need truth of a beautifully phrased song, dredged from a real person's depth of experience, delivered in an honest voice; the more we need the simplicity of paint on canvas, or the arc of a lonely body in the air, or the photographer's unflinching eye. Art, in the larger sense, is the lifeline to which I cling in a confusing, unfair, sometimes dehumanizing world. In my childhood, the nuns and the priests insisted, sometimes in a shrill and punitive tone, that religion was where God resided and where I might find transcendence. I was afraid they were correct for so many years, and that I was the one at fault for not being able to navigate the circuitry of dogma and ritual" (Cash, 2010, p. 235). 
Art has the capacity to disrupt religion: it may destroy your faith and it may save your faith. We know that our brain is wired to be conservative, since the synapses have the inclination to take well known routes. But art can help to change this; it can inspire us to take the route less travelled by, and, as you know very well, that will make all the difference.

At the same time, it is important to understand that what is true for former evangelicals is also true for all human beings. There are so many congregations in society; you have all the religious congregations; you also have the political congregations; you have the business congregations; you have the science congregations and you definitely have the art congregations, even specific Bob Dylan congregations. What Philip Salim Francis learned during his study is: "If this is true for us former evangelicals, it may well be true for other fellow human beings. In completing this study, I feel that I have only just begun to appreciate the many ways the arts can save us - and our society at large - from the temptation of the 'fundamentalist mindset': religious, political, or otherwise" (Los Angeles Review of Books, September 2, 2017).

I, myself, grew up in a conservative religious family, with many of the same methods of identity preservation that Francis describes in his book. My parents were both Christian fundamentalists, but they were also the most loving, caring and tolerant people I have ever known. It is important to acknowledge that this is very possible, in the same way that it is possible to experience liberals that are genuinely intolerant. As the philospher John Gray points out in his book, Seven Types of Atheism: "It is not by accident that neither he nor any of the new atheists promote tolerance as a central value. If ethics can be a science, there is no need for toleration" (Gray, 2018, p. 21).

Consequently, we not only need art to disrupt religion, we also need art to disrupt science and politics as well as our everyday lives - not to mention art. Obviously, we need art to disrupt art, and, to me, this seems to have been Bob Dylan's main project during his long career. He is an "iconic iconoclast, a figure at once revered and reviled who consistently tests the very culture that idolizes and demonizes him at turns" (Baltimore Sun, May 23, 2011). And during this lifelong process of transformation, Bob Dylan has even been willing to let art be disrupted by religion. 


\section{The Born Again Dylan}

Although he had been seriously reflecting upon God since his time in Woodstock in the mid '6os, Dylan had a life changing physical experience with Jesus in a hotel room in Tucson, Arizona, in November 1978: "There was a presence in the room that couldn't have been anybody but Jesus ... Jesus put his hand on me. It was a physical thing. I felt it. I felt it all over me. I felt my whole body tremble" (Cott, 2006, p. 276). And when Bob Dylan changes his mind, he does it in a radical way: "When I believe in something, I don't care what anybody else thinks" (Cott, 2006, p. 283). He even went to The Vinyard School of Discipleship for three months, where he learned to practice fundamentalistic certainty. He adopted the schism between the insiders and the outsiders and, as a consequence of this, he stopped singing his secular songs. Instead he wrote hard, condemning songs - some of them very strong and beautiful - filled with references to the Bible. In "Gonna Change My Way of Thinking" from the album Slow Train Coming (1979), he warns: "Jesus said, "Be ready / For you know not the hour in which I come ... He who is not for Me, is against Me" (Luke 11:23). There is no middle ground; you gotta serve somebody. Bob Dylan also began to preach at the concerts, talking about the end of the world: "The world as we know it now is being destroyed. Sorry, but it's the truth" (Dylan, 1990, p. 35). In the practice of convincing others, you convince yourself; as Philip Salim Francis points out, "you get a performative relationship to certainty" (Francis, 2017, p. 39).

It is interesting that an artist who had been extremely open to all kinds of influences, an artist that had practiced uncertainty seemingly more than anyone else, converted to become a full scale evangelical fundamentalist. But it is not surprising to anyone who has followed Dylan's career that it was impossible for him to remain a fundamentalist for very long. Already one year after he had premiered his religious repertoire at Warfield Theatre in San Franscisco in November, 1979, Dylan started to mix his religious songs with his old secular songs. The schism between the sacred and the secular, between the insiders and the outsiders, which is so important to evangelical fundamentalists, was already breaking down. He already found the pressure from the Vinyard Fellowship confining. 
The background singer Helena Springs said in an interview: "I remember a lot of them pressuring him about a lot of things. They were not allowing him to live. I remember one time he said to me: 'God, it's awfully tight. It's so tight, you know.' He found a lot of hypocrisy in those Jesus people that he had gotten involved with" (The Telegraph, No. 34).

"The transition out of any religious community - and notably evangelicalism - is rarely smooth" (Francis, 2017, p. 5). The whole rigid belief system may tumble down and leave you in a serious crisis. Many people lose their faith altogether. Bob Dylan moved on, but managed to keep his faith. Many of the songs he has written since his evangelical period are very existential and explicitly religious, although many people miss this fact. Both Dylan's lyrics and his comments in interviews show that he has remained a true believer in God, but he is very vague about what kind of faith he is practising. It seems to be an open, mystical faith. In 1997 he said to Jon Pareles ("A Wiser Voice," New York Times archives, 1997) that he at that time subscribed to no organized religion. Rolling Stone magazine asked him directly about his faith in 2007 , and Dylan responded:

Faith doesn't have a name. It doesn't have a category [...]. We degrade faith by talking about religion. (Cott, 2017, p. 488)

Some may think that there's nothing wrong with being born again, but I would argue that it's even better to be born again and again and again. It is obvious that Dylan had the tools to move on from evangelical fundamentalism and still keep his faith. Might it have been Dylan's method for transformation that eventually saved his faith? Whatever the truth may be, here it is, my take on Bob Dylan's ten commandments - ten rules that he may not know about himself.

\section{Be like a sponge}

So many of the people that knew the young Bob Dylan in Greenwich Village in the early '6os have been asked the same question: "How was he, Bob Dylan, what was he like?" A lot of them give the very same answer: "He was like a sponge." The blues musician Tony Glover is one of them: "He was like a sponge, picking up people's mannerisms, accents" (No Direction Home, 
2005). Even Dylan's biographer, Robert Shelton, used this phrase in the very first newspaper article about the young folk singer: "Bob Dylan's highly personalized approach toward folk song is still evolving. He has been sopping up influences like a sponge" (New York Times, September 29, 1961).

This is the opposite of what the evangelical Christian leaders would recommend. They want to keep the hard lines of division between the insiders and the outsiders as strong as possible. Go to Christian schools; stay with Christian friends; listen to Christian music; read Christian literature. "Many evangelicals ... have a built-in-suspicion of the arts, especially 'secular' artistic forms such as popular music and theatre, that goes back as long as there have been evangelicals" (Francis, 2017, p. 27). One of Philip Salim Francis's informants says: “...I imagined little devils trying to steal me away from God. I tried to censor my thoughts, thinking that they were controlled by devils, that they were temptations, leading me away from God" (Francis, 2017, p. 47). Instead Bob Dylan urges us to keep our eyes wide, "cause the chance won't come again, for the times they are a-changin"” (Dylan, 1964).

When I was young, a Christian friend of mine saw me reading a book about "Jesus's false worldview as the basis for his untenable dualism and the illusion of his resurrection" (Dogmet om Jesus, 1965) and asked me: "Do you dare to read this book?" And I answered: "Yes, why not? What should I be afraid of?" If what I believe is true, it won't be changed by a book. If what I believe is wrong, I'd better change my belief. And my belief has been continually changing, or I would rather say, it has been continually growing, very much inspired by Bob Dylan's method for transformation.

\section{Keep the zeitgeist at arm's length}

There are four types of knowns, although Donald Rumsfeld, the Secretary of Defense under George W. Bush at the time, claimed that there were only three. You have the known knowns. That is what you know that you know. Then you have the known unknowns, which is what we know that we don't know. And thirdly, we have the unknown unknowns, that is what we don't know that we don't know. The Secretary of Defense was very worried about the third type, but he forgot the crucial fourth one, as 
the philosopher Slavoj Žižek reminds us: "the unknown knowns" (Žižek, 2004) are the things that we don't know that we know. In our context of keeping the zeitgeist at arm's length, we can call the unknown knowns the zeitgeist, the things that are so obvious that we do not see them. And Žižek emphasizes: "The main danger lies in the unknown knowns."

This is exactly why we should try to keep the zeitgeist at arm's length. Many people are soaked up in the spirit of the times. They go with the flow, if it is the 1960s, the 1980s or the 20oos - they change with the wind, without reflecting upon the values and the view of the world that they embody. Bob Dylan was different, as he confirms in his memoirs: "The madly complicated modern world was something I took little interest in. It had no relevancy, no weight. I wasn't seduced by it" (Dylan, 2004, p. 20).

Actually, this is one of the rules or commandments to which evangelical Christians may also want to subscribe. These fundamentalists also try to keep the zeitgeist at arm's length, because what they believe is often not in tune with the everyday life of most people. They want to keep their faith unchanged; and many Christians believe that their faith has remained unchanged, although it may in fact have changed a lot over the years. The truth is that religious practice changes as much as other practices, but you will never reflect upon this fact if you do not keep the zeitgeist at arm's length.

Bob Dylan has spoken about how important it is to be detached from society to write certain songs: "That is why a lot of people, myself included, write songs when one form or another of society has rejected you. So you can truly write about it from the outside ... outside of the situation you find yourself in" (American Songwriter, January 9, 2012). To be conscious and critical of the zeitgeist is not only important for artists; it is important for all of us, but we are often too eager to melt into the spirit of the times. Dylan has said: "I don't feel obliged to keep up with the times. I'm not going to be here that long anyway ... Jesus, who's got time to keep up with the times?" (Sunday Times, 1st July 1984).

\section{Know tradition thoroughly}

Evangelical Christians may also fancy this commandment, at least initially, because they spend so much time delving into and keeping their 
own tradition alive. But the third commandment does not say that you shall know the tradition thoroughly; it says tradition, which means all traditions, including diverse Christian and other religious beliefs and practices, along with all other kinds of traditions. In other words you must know history and seek out different views, especially those that have a different take on things than prevailing mainstream opinions.

Bob Dylan has soaked up different traditions to an extreme degree. He has had the curiosity, the inner drive and the courage to explore everything. He began with different music traditions. Instead of being satisfied with the popular music of the time, he listened to radio stations from the South that played obscure blues, jazz, gospel and folk records. He also searched for information about these songs and the singers who performed them, wherever he could find it. Later he got into literature and philosophy: "I'd read that stuff. Voltaire, Rousseau, John Locke, Montesquieu, Martin Luther - visionaries, revolutionaries ... it was like I knew those guys, like they'd been living in my backyard" (Dylan, 2004, p. 30).

When he came to New York in the early '6os, he went to the public library to study microfilms from the Civil War and other crucial events from American history. It is interesting that the greatest artist of our time is an autodidact. Dylan stayed at the University of Minnesota for just a few months, but he has had a life-long education that is very eclectic and not determined by academia's standard curriculums: “There is truth in all books. In some kind of way. Confucius, Sun Tzu, Marcus Aurelius, the Koran, the Torah, the New Testament, the Buddhist sutras, the Bhagavad-Gita, the Egyptian Book of the Dead, and many thousands more" (Gilmore, 2012, p. 51).

And if you dare to read books that go against your own faith, against your own preconception of the world, you may be able to widen your world.

\section{Use tradition to make something new}

Know tradition thoroughly, but why? To be able to keep the tradition alive and unchanged? No, not according to Bob Dylan. He has always used tradition to create something new. The old spiritual, "No More Auction 
Block," became "Blowin' In the Wind." The old English folk song, "Scarborough Fair," became "Girl From the North Country." Dylan's "Like A Rolling Stone" was made on the chords Richie Valens put together for "La Bamba." The title was inspired from Muddy Water's song "Rolling Stone." And Dylan's creative use of references has been even broader in his later albums, where "Love and Theft" is very much inspired by the novel, Confessions of a Yakuza (1991), an obscure book by the Japanese writer Junichi Saga. The title of the album, "Love and Theft", is taken from a book by social historian Eric Lott about the blackface minstrelsy and the American working class, hence the quotation marks on the album cover in the album title.

Many people are concerned about tradition in our times. Immigration has made our Western societies pluralistic, also when it comes to cultural heritage and religion. Many people are afraid of Islam, and the right wing populists cash in on this. They want Muslims to leave our countries or at least to stop more immigration. Others - who are more positive towards other religions, and many of those are practicing Christians - say that we need to be confident and assured in our own religious tradition to meet people with different faiths. But the fourth commandment tells us something else: tradition is always changing and you should contribute to this change with your own ideas and experiences. We do not need to be assured in our own belief systems to meet people with other views, that is not dialogue and that is not a way to change, to expand, to grow. We can be openminded, flexible and willing to be changed when we meet people. I believe that this is one of the main reasons to meet other people, to be influenced by them, to learn from their experiences, to be challenged by their traditions and ideas - and if they are good, adopt them, use them to create something new that will eventually contribute to the vitality of your own tradition.

\section{Accept chaos}

Bob Dylan wrote: "I accept chaos. I am not sure whether it accepts me." (Bringing It All Back Home, liner notes). Later, he expanded on this idea in an interview and said: "Chaos is a friend of mine ... truth is chaos, maybe beauty is chaos" (Cott, 2017, p. 54). 
In his Chronicles, Dylan writes about when he began to think about writing his own songs, which was a big step for him: "It dawned on me that I might have to change my inner thought patterns ... that I had been closing my creativity down to a very narrow, controllable scale ... that things had become too familiar and I might have to disorientate myself" (Dylan, 2004, p. 71).

This is what the fifth commandment tells us. At certain times in our lives we need to disorientate ourselves to change our inner thought patterns. The informants in the book When Arts Disrupts Religion express a very different attitude to chaos or uncertainty: "If there was one message that was driven home to me again and again it was that Christians should abstain from many things, especially doubt, because God doesn't like that... (Francis, 2017, p. 19). Another informant says: “I have come to see the ways that being certain is - at least in many evangelical communities - more than a state of mind. It is an identity. 'We were to be non-doubters' ... and this was nonnegotiable” (Francis, 2017, p. 33). What these informants learned by being exposed to art was "that confusion is ok, is actually a somewhat natural state of being" (Francis, 2017, p. 54). An informant says: "The not-knowing needed form of some kind. This ... is the realm of the arts. Poetry, visual art, literature, and silence speak the language of not-knowing better than logic or creed" (Francis, 2017, p. 67f). This is especially true of art that is so complex and existential as Bob Dylan's oeuvre.

We can never control reality, and you will lose your freedom if you try. Instead we should accept chaos and embrace uncertainty. We should not look upon chaos as an enemy, as an anomaly, rather we should see chaos as a friend, even as a beautiful friend.

\section{Find your own vocation}

Life is chaos, but it is not pure chance, according to Bob Dylan, who has always had a strong sense of destiny. When he arrived in New York for the first time in January 1961, he experienced that there were a lot of better singers and musicians around, but in spite of that he had a strong feeling that "destiny was about to manifest itself. I felt like it was looking at me 
and nobody else" (Dylan, 2004, p. 22). In an interview with Christopher John Farley in Time, Dylan says it even more emphatically: "I've had a God-given sense of destiny. This is what I was put on earth to do. Just like Shakespeare was gonna write plays, the Wright Brothers were gonna invent an airplane, like Edison was gonna invent a telephone. I was put here to do this. I knew I was gonna do it better than anybody ever did it" (Time, Steptember 17, 2001).

We are all tangled up in the foggy web of destiny, but our fate is not completely predetermined, according to Dylan, if only our will power is strong enough: "With strength of will you can do anything. With will power you can determine your destiny" (Rolling Stone, January 26, 1978).

To have a will power like that, you need a purpose, a calling, a vocation. Dylan has been fortunate to have this sense of vocation since he was a child, but one day you may lose it, one day you may feel an emptiness inside, to which you cannot relate, brought on by a simple twist of fate. Dylan lost it completely during a concert at the Piazza Grande in Locarno, Switzerland. Everything fell apart, he could not make a sound. Then something strange happened: “It's almost like I heard it as a voice. It wasn't like it was even me thinking it. I'm determined to stand, whether God will deliver me or not. And all of a sudden everything exploded" (Newsweek, 1997). What he got back was a purpose, a new vocation: "If I ever wanted a different purpose, I had one. It was like I'd become a new performer, an unknown one in the true sense of the word" (Dylan, 2004, p. 153).

Many of us have big dreams. We want to contribute, we want to make a difference, in some sense we want to save the world, at least to do our part, but depth psychologist Bill Plotkin advises us not to put this burden on our shoulders: "The gift you carry for others is not an attempt to save the world but to fully belong to it. It's not possible to save the world by trying to save it. You need to find what is genuinely yours to offer the world before you can make it a better place. Discovering your unique gift to bring to your community is your greatest opportunity and challenge. The offering of that gift-your true self-is the most you can do to love and serve the world. And it is all the world needs" (Plotkin, 2003, p. 13).

The most common regret that people have at the end of their lives, according to the Australian nurse and writer Bronnie Ware, is: "I wish 
I'd had the courage to live life true to myself, not the life others expected of me" (The Guardian, February 1, 2012).

\section{Leave the ones who hold you back}

It is hard to imagine how the young Bob Dylan was able to leave the folk music movement. Only 20 years old, he wrote "Blowin' In The Wind" and was immediately proclaimed a prophet. 21 years old he wrote "A Hard Rain's A-Gonna Fall," 22 years old he wrote "Times They Are A-Changin'". To make such an amazing impact at such a young age, and still have the courage to leave the people that love you is almost unfathomable. Who else would have done that? If you are in with your crowd, if you are appreciated, even worshiped, why leave, why move on? But he did.

"You must leave now, take what you need, you think will last", Bob Dylan sings in "It's All Over Now, Baby Blue", one of so many songs about break up: "Leave your stepping stone behind, something calls for you". Bob Dylan left the folk movement, because he had to be true to his artistic vocation. The folk movement fought a very righteous cause together with the Civil Rights Movement, but their views became increasingly limited. All congregations face this danger - whatever good cause they fight for - you narrow your scope, you lose your ability to see outside the box. Therefore, if you cannot change it, you will have to leave it.

It's usually hard to leave any congregation. The student Thomas at the Oregon Extension, who is one of Francis's informants, knows all about this: "They looked at me in disbelief when I told them I was leaving the church and that I was no longer certain about the who or what or if of God. And I looked back at them in disbelief. How had it come to this? Some of them wiped the dust off their shoes, others wept, and others told me I was under the sway of Satan. How could I protest? They had trusted me before, why should I expect them to trust me again?" (Francis, 2017, p. 36).

Maybe it was also difficult for Bob Dylan to leave the folk music movement? The audiences booed, a man yelled - infamously - "Judas" at the Manchester Free Trade Hall. Many of the people in the movement, some of them close friends, looked upon him as a traitor - the most gifted person in the movement sold out for personal glory, instead of fighting the 
good cause - at least that was what they thought, but they were wrong, as the gatekeepers of the pure, untainted faith usually are.

Many of us have experienced this: what was freedom, becomes a prison. What was truth, becomes a lie. The group, or the congregation you are a part of begins to confuse cultural expressions with real values. A polka dot shirt means that you set the individual values before the collective. An electric guitar means that you have sold out to commercial interests. Then someone must be brave enough to stand up and say, "This guitar doesn't mean anything; it's an instrument for God's sake." Sometimes it doesn't take more than this to become a traitor. You can change the polka dot shirt or the electric guitar with any other object that becomes a symbol for something. When the congregation agrees about this symbol, you know it is time to leave the ones who say they love you, to save yourself and whatever you believe in.

\section{Add. Don't subtract}

Bob Dylan has gone through many changes during his life, but in spite of all this, I cannot recall one single time that Dylan has dissociated himself from any of his earlier phases. They all seem to be an integral part of his personality; and I believe this is a conscious strategy. It is also a wise strategy for a person of faith. Because none of us have a direct access to God, or to reality, which, for me at least, is the one and the same thing. It is true what Paul said: "For now we see through a glass, darkly; but then face to face: now I know in part; but then shall I know even as also I am known" (1 Cor. 13:11-12). Our knowledge about reality will always be partial. This is why it is wise to add to our faith, and not to subtract from it.

Somewhere in my more than 6o-year-old body, there is a child, who feels like a child, who believes like a child. Somewhere in my aging body there is still a youthful voice, too sure about his opinions. All my experiences, and all your experiences, are contained somewhere in our bodies, and if we want, we can choose to embrace everything, all our phases, all our knowledge, all our beliefs. Add. Don't subtract. We should not make ourselves smaller than we are. We may even contain opposites. It is perfectly possible to believe and not believe in God at the same time. 
One of the students at Oregon said: "If anything, the Oregon Extension taught me to desire to live my life in widening circles of embrace, even of my evangelical background. There were echoes of Walt Whitman up there on the mountain: I am large, I contain multitudes, they said, I even contain evangelicalism. The Oregon Extension is about the embrace of multiplicities and liminal spaces" (Francis, 2017, p. 18).

\section{Find religiosity in the music}

What does Bob Dylan believe in? We got a good answer to this question from Dylan himself, in connection with the release of one of his most important albums, Time Out of Mind (1997), when he confessed: "Here's the thing with me and the religious thing. This is the flat-out truth: I find the religiosity and philosophy in the music. I don't find it anywhere else. Songs like 'Let Me Rest on a Peaceful Mountain' or 'I Saw the Light' that's my religion. I don't adhere to rabbis, preachers, evangelists, all of that. I've learned more from the songs than I've learned from any of this kind of entity. The songs are my lexicon. I believe the songs" (Newsweek, October 5, 1997).

In a different interview around the same time, he adds to this reflection: "I believe in a God of time and space, but if people ask me about that, my impulse is to point them back toward those old songs. I believe in Hank Williams singing 'I Saw the Light.' I've seen the light, too" (The New York Times, 28th September, 2017).

By the old songs, Dylan obviously means the old folk songs, religious ones, like the songs mentioned above, but also secular ones, strange songs with the ability to transport you to a different world far from your well known social reality: "It is a mythical world, speaking of deep truths about life, death, God and the mystery of life. You have to believe. Folk music, if anything, it makes a believer out of you" (Dylan, 2004, p. 256).

The last Christmas my father was alive, he celebrated the holiday in our house with me and my wife and our three children. We stayed up late several nights, singing songs, old folk songs with English lyrics, a language my father never learned, but I took time to translate the lyrics for him. There were songs like "I Am Weary (Let Me Rest)" and "Will the Circle 
Be Unbroken”. Our children added newer songs by Gillian Welch, that sounded as old as the other ones, and my father immediately understood and recognized that these songs are similar to the songs that we sang in the chapel when I was a child. Since then, I had rarely been able to practice faith together with my father, because the common faith we shared had taken different directions and had moved into different modes of expression, but at this last Christmas celebration, we were able to share a real religious experience together: the circle was unbroken, thanks to the songs.

When we went to bed on the last night of the Christmas holiday, my father exclaimed: "Three nights in a row, I have been able to enjoy the music and the warm togetherness. Three nights, I am so grateful.” Early the next morning I had to drive him to the hospital with severe chest pains. Three weeks later, he died, almost 90 years old.

Like Bob Dylan, I believe in the old songs, but I also believe in the new songs. I believe in all songs that sing truths about our complex and often contradictory lives. In the same way I also believe in literature, in theatre, in dance, and in visual arts; and I will definitely not make a distinction between sacred art and secular art. I got rid of this false dichotomy a long time ago. All art that speaks truthfully about life is sacred. Not all art that claims to be sacred speaks truthfully about life.

Rosanne Cash compared art to religion and concluded: "Art and music have proven to be more expansive, more forgiving, and more immediately alive. For me, art is a more trustworthy expression of God than religion" (Cash, 2010, p. 235).

\section{He not busy being born, is busy dying}

This 1oth commandment may be seen as the summary of all the commandments I have found, but it is also a problematic commandment that can be understood in at least two different ways. This well known expression appears in one of Bob Dylan's greatest songs of all time, the desperate "It's All Right, Ma (I'm Only Bleeding)", from the album Bringing It All Back Home (1965). It is a song about "the demands, expectations and manipulations of a world in which 'not much is really sacred"” 
(Dylan, 2018, p. 103). The young protagonist is living in a chaotic world; everything is going on at the same time, in all directions: "While preachers preach of evil fates / Teachers teach that knowledge waits / Can lead to hundred-dollar plates..." But he is already disillusioned: "there is no sense in trying."

Everything is false, "The hollow horn plays empty words," and it is actually these hollow horns that seem to warn that, "He not busy being born, is busy dying".

I believe in the 1oth commandment; I think it is true that "he not busy being born, is busy dying," but in this song the expression comes from outside, from the others, from society, from the authorities. Understood in this way, I would not recommend this 1oth commandment at all, but there is a different way to understand this expression, which I learned from the movie Lady Bird (2018). The main character, Christine, is graduating from high school and she calls herself Lady Bird, because she is ready to fly. After finishing high school, she wants to go to college in New York, where she can delve into art and culture and meet interesting people. She's from Sacramento, from the wrong side of the tracks, the poor side. Her mother doesn't want her to leave for the big city and says something like: You will never be accepted to a college in New York, your grades are too bad; and besides you have all the violence and terrorism in the big city. You are gonna go to a college here in Sacramento.

There is an important scene in the movie, when Lady Bird is trying on a new dress for her graduation party. From the inside of the fitting room she asks her mother who is standing outside: "Mom, do you like me?" And the mother answers: "I love you, Christine" - which is not a good answer, because it is the default answer for parents. Parents are supposed to love their children. This was not what Lady Bird was asking about, however, so she repeats her question: "But do you like me?" And her mother takes a deep breath - but It's All right, Ma (You're Only Sighing) - before she says, "I just want you to be the best version of yourself, Christine." Then, Christine, or Lady Bird, gives this very good response: "What if this is the best version of myself?"

The 1oth commandment, "He not busy being born, is busy dying," is not about fighting to be the best version of yourself - especially not what 
other people think is the best version of yourself. The 1oth commandment is about being open to new possibilities, new acquaintances, new ideas, new concepts, that will give you different views and experiences, and, most important, it will give you more alternatives when you yourself have to choose which version of your life you want to live. Whether you decide to go to New York to experience art and culture or you choose to remain in your home town, or anything and everything in between: the crucial thing is to realize that you have alternatives - and the more, the better, because without alternatives there is no real choice.

This is the reason why we should try to be like a sponge, but keep the zeitgeist at arm's length; know the tradition thoroughly, but use it to create something new; accept chaos, but find our own vocation; leave those who hold us back, but add to all our experiences; and find religiosity in music, or other arts, so that we can stay busy being born, until death comes to us all.

\section{Literature}

Bible, The. King James Bible, kingjamesbibleonline.org.

Blue, D. (2008). From Stone to Living Word: Letting the Bible Live Again. Grand Rapids: Brazos Press.

Brown, M. (1984). Jesus, Who's Got Time to Keep Up with the Times?, Sunday Times, July 1.

Cash, R. (2010). Composed, a Memoir. New York: Viking.

Cott, J. (Ed.). (2006). Dylan On Dylan: The Essential Interviews. London: Hodder \& Stoughton.

Cott, J. (Ed.). (2017). Bob Dylan: The Essential Interviews. New York: Simon \& Scuhster.

Dylan, B. (1990). Saved! The Gospel Speeches. Madras \& New York: Hanuman Books.

Dylan, B. (2004). Chronicles. New York: Simon \& Schuster.

Dylan, B. (2018). Mondo Scripto. London: Halcyon Gallery.

Edwien, A. (1965). Dogmet om Jesus. Om Jesu feilaktige verdensbilde som grunnlag for hans uholdbare dualisme og for illusjonen om hans oppstandelse. Oslo: Pax.

Farley, C. J. (2001). Legend of Dylan, Time, September 17.

Francis, P. S. (2017). How Art Can Save Us from Ourselves, Los Angeles Review of Books, September 2.

Francis, P. S. (2017). When Art Disrupts Religion. Oxford: Oxford University Press.

Gerwig, G. (2018). Lady Bird. Focus Features. 
Gilmore, M. (2012). Bob Dylan. The Rolling Stone Interview. Rolling Stone. Issue 1166. September 27.

Gray, J. (2018). Seven Types of Atheism. London: Penguin Books.

Pareles, J. (1997). A Wiser Voice Blowin' In The Autumn Wind, Jon Pareles, New York Times archives.

Plotkin, B. (2003). Soulcraft: Crossing into the Mysteries of Nature and Psyche.

Novato, California: New World Library.

Salvucci, J. (2011). Dylan at 70: Embracing the Chaos. Baltimore Sun, May 23.

Scorsese, M. (2005). No Direction Home. Paramount Pictures.

Sloman, L. (2002). On the Road with Bob Dylan. New York: Three Rivers Press.

Ware, B. (2012). The Top Five Regrets of the Dying. London: Hau House.

Žižek, S. (2004). What Rumsfeld doesn't know that he knows about Abu Ghraib, In These Times, May 2.

\section{Author description}

Petter Fiskum Myhr gained his cand. philol. in literature from the University of Bergen. He has worked as a journalist and editor for the Norwegian Broadcasting Corporation. He was the first director of Rockheim, the national museum for popular music in Norway. Since 2013 he has been the director for Trondheim International Olavsfest. Petter Fiskum Myhr has written and contributed to several books about Bob Dylan, among them: Bob Dylan - jeg er en annen, Oslo: Historie og Kultur 2011, Bob Dylan. Mannen, myten og musikken. Oslo: Dreyer Forlag, 2011 and Bob Dylan Leksikon. Oslo: Historie \& Kultur, 2012.

\section{Forfatteromtale}

Petter Fiskum Myhr er fra Trondheim, Norge. Utdannet cand. philol. i litteratur fra Universitetet i Bergen. Han har arbeidet som journalist og redaktør i NRK. Han var også den første direktøren for Rockheim, det nasjonale museet for populærmusikk. Siden 2013 har han vært direktør for Trondheim Internasjonale Olavsfest. Petter Myhr har skrevet og bidratt til flere bøker om Bob Dylan, blant dem: Bob Dylan - jeg er en annen, Oslo: Historie og Kultur 2011, Bob Dylan. Mannen, myten og musikken. Oslo: Dreyer Forlag, 2011 og Bob Dylan Leksikon, Oslo Historie \& Kultur, 2012. 



\section{List of Dylan Songs}

\section{Credits}

All rights reserved. International copyright secured. Reprinted by permission.

«A Hard Rain's A-Gonna Fall» Copyright @ 1963 Warner Bros. Inc.; renewed 1991 by Special Rider Music «Ain’t Talking» Copyright $\odot 2006$ Special Rider Music «All along the Watchtower» Copyright $\odot 1968$ Dwarf Music «Angelina» Copyright $\odot 1981$ Special Rider Music «Are You Ready?» Copyright $\odot 1980$ Special Rider Music «Blowin’ in the Wind» Copyright $\odot 1962$ Warner Bros. Inc.; renewed 1990 Special Rider Music «Can You Please Crawl Out Your Window?» Copyright @ 1 1965, 1966 by Warner Bros. Inc.; renewed 1993 by Special Rider Music «Caribbean Wind» Copyright (c) 1985 Special Rider Music «Cross the Green Mountain» Copyright $\odot 2002$ Special Rider Music «Changing of the Guards» Copyright $\odot 1978$ Special Rider Music «Dead Man, Dead Man» Copyright ( 1981 Special Rider Music «Desolation Row» Copyright (C) 1965 Warner Bros. Inc.; renewed 1993 Special Rider Music

«Do Right To Me Baby (Do Unto Others)» Copyright ( 1979 Special Rider Music «Every Grain of Sand» Copyright $\odot 1981$ Special Rider Music «Everything Is Broken» Copyright $\odot 1989$ Special Rider Music «Father of Night» Copyright $\odot 1970$ Big Sky Music «Foot of Pride» Copyright (C) 1983 Special Rider Music «Gonna Change My Way of Thinking» Copyright @ 1979 Special Rider Music 
«Gotta Serve Somebody» Copyright (C) 1979 Special Rider Music

«Highlands» Copyright (C) 1997 Special Rider Music

«Hurricane» Copyright (C) 1975 Ram's Horn Music, renewed 2002 Ram's

Horn Music

«I and I» Copyright (C) 1983 Special Rider Music

«I Believe in You» Copyright (C) 1979 Special Rider Music

«I Dreamt I Saw Saint Augustine» (C) 1968 Dwarf Music

«Idiot Wind» Copyright (C) 1974 Ram’s Horn Music, renewed 2002 Ram’s Horn Music

«In the Summertime» Copyright (C) 1981 Special Rider Music

«Is Your Love in Vain» Copyright (C) 1978 Special Rider Music

«It's Alright, Ma (I’m Only Bleeding)» Copyright (C) 1965 Warner Bros.

Inc.; renewed 1991, 1993 Special Rider Music

«Jokerman» Copyright (c) 1983 Special Rider Music

«Lay, Lady, Lay» Copyright (C) 1969 Big Sky Music

«Let Me Die in My Footsteps» Copyright (C) 1963, 1965 Warner Bros. Inc.; renewed 1993 Special Rider Music

«Like a Rolling Stone» Copyright (C 1965 Warner Bros. Inc.; renewed 1993 Special Rider Music

«Long Ago, Far Away» Copyright (C) 1962, 1968 Warner Bros. Inc.; renewed 1990, 1996 Special Rider Music

«Man of Peace» Copyright (C) 1983 Special Rider Music

«Masters of war» Copyright (C) 1963 Warner Bros. Inc.; renewed 1991 Special Rider Music

«My back pages» Copyright (C) Warner Bros. Inc.; renewed 1992 Special Rider Music

«Need a Woman» Copyright (c) 1981 Special Rider Music

«Neighborhood Bully» Copyright (C) 1983 Special Rider Music

«Nettie Moore» Copyright (C) 2006 Special Rider Music

«North Country Blues» Copyright (C) 1963, 1964 Warner Bros. Inc.; renewed 1991, 1992 Special Rider Music

«Pay In Blood» Copyright (C) 2012 Special Rider Music

«Political World» Copyright (C) 1989 Special Rider Music

«Precious Angel» Copyright (C) 1979 Special Rider Music

«Pressing On» Copyright (C) 1980 Special Rider Music 
«Property of Jesus» Copyright (C) 1981 Special Rider Music «Ring Them Bells» Copyright (C) 1989 Special Rider Music «Saved» Copyright (C) 1980 Special Rider Music «Señor (Tales of Yankee Power)» Copyright (C) 1978 Special Rider Music «Shelter from the Storm» Copyright (C) 1974 Ram's Horn Music, renewed 2002 Ram's Horn Music

«Shot of Love» Copyright (C) 1981 Special Rider Music «Shooting Star» Copyright (C) 1989 Special Rider Music «Slow Train» Copyright (C) 1979 Special Rider Music «Solid Rock» Copyright (C) 1980 Special Rider Music «Subterranean Homesick Blues» Copyright (C) 1965 Warner Bros. Inc.; renewed 1993 Special Rider Music «Tempest» Copyright (C) 2012 Special Rider Music «The Groom's Still Waiting At the Altar» Copyright (C) 1981 Special Rider Music

«The Leeve’s Gonna Break» Copyright (C) 2006 Special Rider Music «The Man in the Long Black Coat» Copyright (C) 1989 Special Rider Music «The Times They Are A-Changin'» Copyright 1963, 1964 Warner Bros. Inc.; renewed 1991, 1992 Special Rider Music «This Dream of You» Copyright (C) 2009 Special Rider Music «To Ramona» Copyright (C) 1964 Warner Bros. Inc.; renewed 1992 Special Rider Music

«Time Passes Slowly» Copyright (C) 1970 Big Sky Music «True Love Tends to Forget» Copyright (C) 1978 Special Rider Music «Trouble in Mind» Copyright (C) 1979 Special Rider Music «Union Sundown» Copyright (C) 1983 Special Rider Music «What Good Am I» Copyright (c) 1989 Special Rider Music «With God on Our Side» Copyright (C) 1964 Warner Bros. Inc.; renewed 1991 Special Rider Music «When He Returns» Copyright (C) 1979 Special Rider Music «When the Deal Goes Down» Copyright (C) 2006 Special Rider Music «When You Gonna Wake Up» Copyright (C) 1979 Special Rider Music «Yonder Comes Sin» Copyright (C) 1980 Special Rider Music «You Ain’t Goin' nowhere» Copyright (C 1967 Dwarf Music 
